\title{
Batteries in Smart Microgrids
}

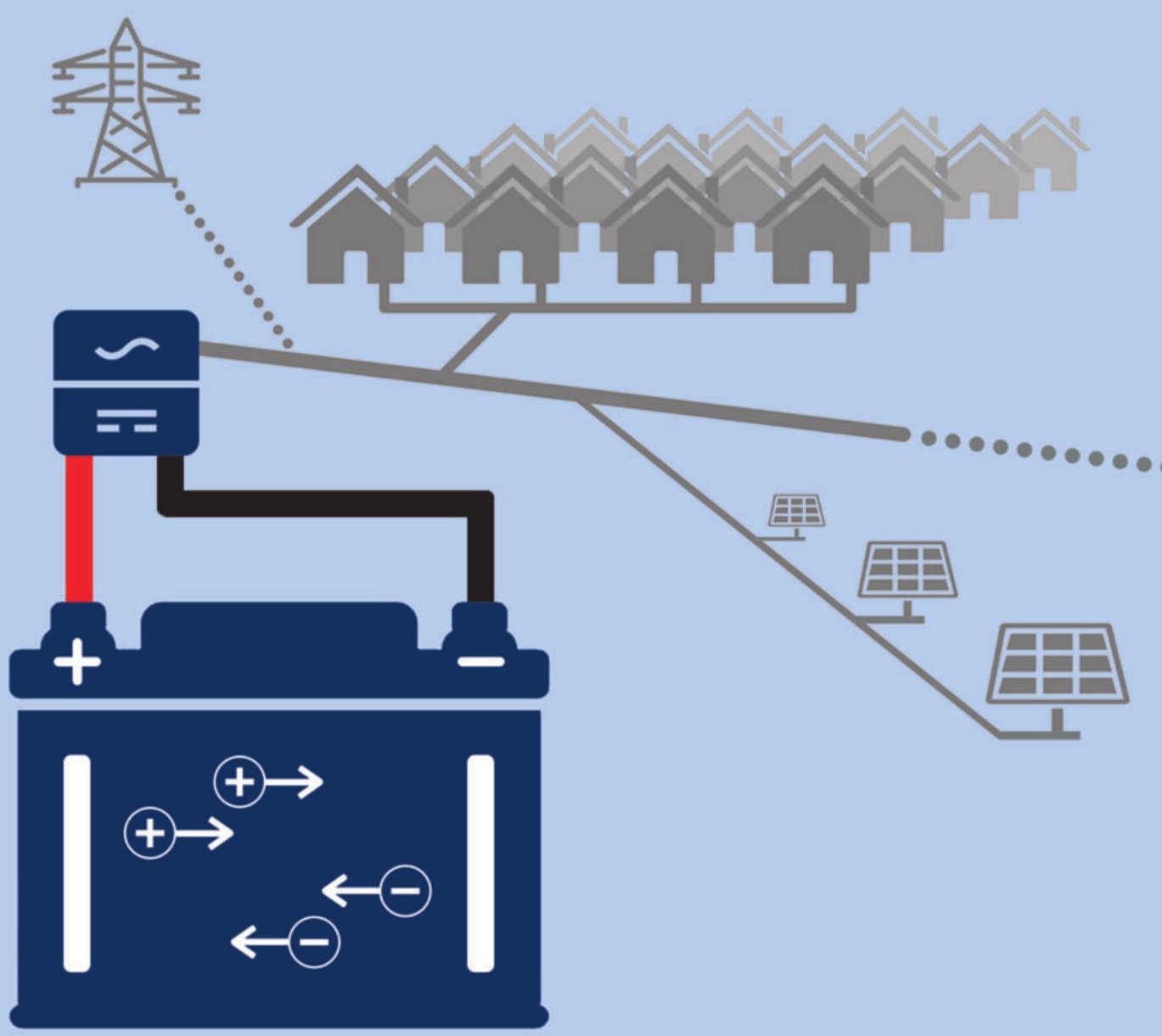

Bart Homan 
Members of the graduation committee:

Prof. dr. ir. G. J. M. Smit Prof. dr. J. L. Hurink

Prof. dr. P. J.M. Havinga

Prof. dr. ir. G. J. Heijenk

Prof. dr. ir. P. M. Herder

Prof. dr. M. Gibescu

Dr. M. V. ten Kortenaar

Dr. ir. R. P. van Leeuwen

Prof. dr. J. N. Kok
University of Twente (promotor)

University of Twente (promotor)

University of Twente

University of Twente

Delft University of Technology

Utrecht University

Dr Ten B.V.

Saxion University of Applied Sciences

University of Twente (chairman and secretary)

\section{UNIVERSITY OF TWENTE.}

Faculty of Electrical Engineering, Mathematics and Computer Science (EEMCS), Computer Architecture for Embedded Systems (CAES) group and Discrete Mathematics and Mathematical Programming (DMMP) group.

\section{DIGITAL SOCIETY \\ INSTITUTE}

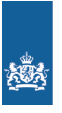

Rijksdienst voor Ondernemend Nederland
IDS Ph.D. Thesis Series No. 20-001

Institute on Digital Society

PO Box 217, 7500 AE Enschede, The Netherlands

This research is supported by Rijksdienst voor Ondernemend Nederland (RVO) through project TKI Switch2Smargrids "Smart Grid Evolution" (project number TESG113013). This research is supported by $\mathrm{Dr}$ Ten B.V.

Copyright ${ }^{\odot} 2020$ Bart Homan, Enschede, The Netherlands. This work is licensed under the Creative Commons AttributionNonCommercial 4.0 International License. To view a copy of this license, visit http://creativecommons.org/licenses/ by-nc/4.0/deed.en_US.

This thesis was typeset using ${ }^{\mathrm{A}} \mathrm{T} \mathrm{EX}, \mathrm{TikZ}$, and Vim. This thesis was printed by Gildeprint Drukkerijen, The Netherlands.

ISBN $\quad 978-90-365-4957-8$

ISSN 2589-7721; IDS Ph.D. Thesis Series No. 20-001

DOI $10.3990 / 1.9789036549578$ 


\title{
Batteries in SMart Microgrids
}

\author{
PROEFSCHRIFT
}

ter verkrijging van

de graad van doctor aan de Universiteit Twente, op gezag van de rector magnificus, prof. dr. T. T. M. Palstra, volgens besluit van het College voor Promoties in het openbaar te verdedigen op woensdag 4 november 2020 om 12.45 uur

door

\section{Bart Homan}

geboren op 14 juni 1984 te Sassenheim 
Dit proefschrift is goedgekeurd door:

Prof. dr. ir. G. J.M. Smit (promotor) Prof. dr. J.L. Hurink (promotor)

Copyright ${ }^{\circ} 2020$ Bart Homan ISBN 978-90-365-4957-8 
Voor mijn ouders

Hans E Heidi

Mijn zus en zwager

Nini E Joey

En mijn nichtje

Lena 


\section{Abstract}

To counter the effects of global climate change, attributed to the $\mathrm{CO}_{2}$ emissions resulting from burning fossil fuels for generating electricity and heat, global efforts are being made to achieve an energy transition. This includes that the share of energy generated using sustainable sources (e.g. solar, wind, hydro) should be increased, while the share of energy generated using fossil sources (e.g. natural gas, coal, oil) should be decreased, ultimately phasing out the usage of fossil fuels altogether. How this energy transition should be achieved, or even when the energy transition should be completed is subject of heated debates in political arenas, courts of law and the society as a whole. Whether or not future electricity demands can be met by sustainable sources is a particular important part of this debate. On the one hand, fossil fuels are (for the moment) cheap and readily available, by using fossil fuels it is always possible to generate the appropriate amount of electricity to match the demand. On the other hand, generating electricity from sunlight or wind can only be done when enough sunlight is available or the wind-speed is in an appropriate bandwidth. However, as electricity is also used during the night, and on cloudy, windless or stormy days, using sustainable energy sources as the primary supply for electricity generation can lead to a significant mismatch between supply and demand. This can imply that sometimes the electricity generated by solar parks during the day has to be curtailed because there is no demand for it, while during the night electricity still has to be generated using fossil fuels to meet the demand.

A solution to this problem seems obvious: store the electricity. This allows to generate electricity using sustainable sources when available, and to store a sufficient amount to be able to meet the demand at all times. Although, this solution sounds simple, still many questions remain. Which type of storage should be used?, Where should the storage be located?, What should be the capacity of the storage?, How should the storage be used?, etc. In this thesis these types of questions are addressed for a specific type of storage: batteries. To answer these questions, and to support the important decisions necessary to complete the energy transition, three contributions are made:

The first contribution is the development of the diffusion buffer model (DiBumodel) for battery state of charge (SoC) prediction. This model is specifically designed to be used in simulation tools for energy management in (smart) grids. Hence, this model should be a consolidation of broad applicability, accuracy and simplicity. The broad applicability of the DiBu-model is demonstrated by accurate predictions of the SoC of Lead-acid, Lithium-ion Polymer and Lithium 
Iron-phosphate batteries under various scenarios. The accuracy of the model is demonstrated by comparing the predicted $\mathrm{SoC}$ for various scenarios to the SoC calculated from measurements on real batteries subjected to these scenarios. The results show that it is possible to accurately predict the SoC for these types of batteries using the DiBu-model, where the difference between the predicted SoC and the SoC calculated from measurements is generally less than $5 \%$. The broad applicability and accuracy are also demonstrated by accurate SoC predictions on an experimental Seasalt battery, although a slight modification to the model was necessary in this case. The simplicity is demonstrated by integrating the DiBu-model in the DEMKit smart grid energy management toolkit. Here the results show that by using the DiBu-model more realistic predictions of the SoC can be made, compared to an idealized battery model used previously. The integration of the model in DEMKit is validated by comparing the SoC predicted using DEMKit to the SoC derived from measurements on an actual battery. The difference between the predicted and measured SoC is generally less than $1.5 \%$.

The second contribution is the so called " 16 houses case" in which the integration of batteries in a smart microgrid is considered. More specifically the possibilities of "soft-islanding" (near autarkic behaviour) a microgrid with 16 houses is investigated. The research is focussed on an idealized "greenfield" neighbourhood where energy is generated by PV-panels as well as by a CHP and energy is stored using batteries as well as a heat buffer. Firstly, a proper sizing of the equipment is determined based on energy production and consumption data of several weeks spread over the year. Secondly, one-year simulations for several scenarios are presented and the degree of autarky (DoA) for each scenario is compared. It is demonstrated that a (nearly) autarkic operating microgrid can be achieved by combining the proper sizing of energy generation and storage assets, with an advanced control. It is possible to achieve a DoA of $99.1 \%$ over a year, meaning that less than one percent of the energy has to be imported from the main grid. Subsequently the tools and methods used for the ideal neighbourhood are applied in a case study of a real neighbourhood: Markluiden. For this neighbourhood it is possible to reach a DoA of around $91 \%$ over a year.

The third contribution concerns the Seasalt battery, a novel battery currently under development at Dr Ten B.V. The Seasalt battery is particularly suitable for stationary use, e.g. as a home or neighbourhood battery. In that role it is an alternative to e.g. Lead-acid and Lithium-ion Polymer batteries. A detailed description of the battery and its behaviour is given, in addition to a discussion of its advantages and disadvantages. The advantages include the usage of environmentally friendly and (where possible) sustainable materials in its construction, and limited risks to health and safety compared to Lead-acid and Lithium-ion Polymer batteries. Disadvantages include a lower capacity / weight and capacity / volume ratio in comparison with the aforementioned batteries. Furthermore, examples of real-world application of the Seasalt battery are discussed. Finally, the prevention of dendrites forming at the anode of the Seasalt battery, which was a particularly challenging aspect of the battery design, is discussed in detail. 


\section{SAMENVATTING}

Om de effecten van de klimaatverandering tegen te gaan, die veroorzaakt wordt door de uitstoot van $\mathrm{CO}_{2}$ als gevolg van het gebruik van fossiele brandstoffen, wordt er wereldwijd gewerkt aan het bereiken van een energietransitie. Dit houdt o.a. in dat het aandeel van energie gewonnen uit hernieuwbare bronnen (zoals zon, wind en water) vergroot moet worden, terwijl het aandeel van energie dat gewonnen wordt uit fossiele brandstoffen (zoals aardgas, aardolie en steenkool) verkleind moet worden, met als einddoel het beëindigen van het gebruik van fossiele brandstoffen. Hoe deze energietransitie bereikt moet worden, of zelfs wanneer deze transitie compleet zou moeten zijn is onderdeel van verhitte debatten in politieke arena's, rechtszalen en in de samenleving. Een belangrijk onderdeel van dit debat is of energie gewonnen uit hernieuwbare energiebronnen voldoende is voor de toekomstige energievraag. Aan de ene kant zijn fossiele brandstoffen (voorlopig) goedkoop en gemakkelijk verkrijgbaar, en het is altijd mogelijk om de juiste hoeveelheid elektriciteit te genereren om te voldoen aan de actuele vraag, wanneer er gebruik gemaakt wordt van fossiele brandstoffen. Aan de andere kant zitten er nogal wat haken en ogen aan het genereren van elektriciteit uit hernieuwbare bronnen, zoals zonlicht en wind. Dit kan namelijk alleen als er voldoende zonlicht is en als de windsnelheid in de juiste bandbreedte is. Toch wordt er ook 's avonds en op windstille of stormachtige dagen elektriciteit gebruikt, waardoor het gebruik van uitsluitend elektriciteit opgewekt uit hernieuwbare bronnen een discrepantie tussen de actuele vraag en aanbod kan veroorzaken. Dit kan er vervolgens toe leiden dat er overdag elektriciteit opgewekt in zonneparken gedumpt moet worden, terwijl er 's avonds extra elektriciteit opgewekt moet worden uit fossiele brandstoffen om aan de actuele vraag te voldoen.

De oplossing voor dit probleem is op het eerste gezicht zonneklaar: elektriciteitsopslag. Immers, opslag van elektriciteit maakt het mogelijk om elektriciteit uit hernieuwbare bronnen te genereren wanneer dat mogelijk is, en genoeg op te slaan om altijd aan de actuele vraag te voldoen. Hoewel deze oplossing simpel klinkt, zijn er nog veel vragen onbeantwoord. Welk type elektriciteitsopslag is het meest geschikt?, Waar kan de opslag het beste geplaatst worden?, Welke opslagcapaciteit is voldoende?, Hoe precies moet je de beschikbare capaciteit inzetten? Dit is het soort vragen waarop in dit proefschrift de antwoorden gezocht worden, toegespitst op één specifiek type opslag van elektriciteit: accu's. In dit proefschrift worden drie bijdragen gedaan om deze vragen te beantwoorden en bij te dragen aan de kennis die nodig is voor het maken van de belangrijke beslis- 
singen die genomen zullen moeten worden om een energietransitie te bereiken.

De eerste bijdrage is de ontwikkeling van het diffusie buffer model (DiBu-model) voor de voorspelling van de state of charge (SoC) van een batterij. Dit model is speciaal ontwikkeld voor gebruik in simulatie software voor energiemanagement in smart-grids. Daarom combineert dit model een brede toepasbaarheid, nauwkeurigheid en eenvoud. De brede toepasbaarheid wordt aangetoond met nauwkeurige voorspellingen voor de SoC van Loodzuur, Lithium-ion en Lithium ijzerfosfaat batterijen in meerdere scenario's. De nauwkeurigheid van het model wordt gedemonstreerd door vergelijkingen te maken tussen de voorspelde SoC en de SoC berekend uit metingen aan echte batterijen in dezelfde scenario's. De resultaten wijzen uit dat het mogelijk is om de SoC van de drie verschillende types batterijen te voorspellen met het DiBu-model, waarbij het verschil tussen de voorspelde $\mathrm{SoC}$ en de $\mathrm{SoC}$ berekend uit de metingen over het algemeen minder is dan $5 \%$. De brede toepasbaarheid en nauwkeurigheid worden ook gedemonstreerd door accurate voorspellingen van de SoC voor de experimentele Zeezoutbatterij, toch was daarvoor een kleine aanpassing aan het model noodzakelijk. De eenvoud van het model is aangetoond door het model te integreren in DEMKit, een softwarepakket voor energiemanagement in smart-grids. De resultaten wijzen uit dat er, in vergelijking met het eerder gebruikte geïdealiseerde model, meer realistische SoC voorspellingen gedaan kunnen worden. De juistheid van de integratie van het model wordt gedemonstreerd door een vergelijking te maken tussen voorspellingen gedaan met DEMKit en metingen aan een echte batterij. Het verschil tussen de voorspelde SoC en de SoC berekend uit de metingen is in het algemeen minder dan $1.5 \%$.

De tweede bijdrage is de "16 houses case"casus, waarin de integratie van batterijen in een smart microgrid onderzocht is. Het onderzoek is meer specifiek gericht op de mogelijkheden om soft-islanding gedrag (bijna autarkisch gedrag) te bereiken in een smart microgrid van 16 huizen. Het onderzoek is gericht op een geïdealiseerde "greenfield"wijk, waar energie wordt opgewekt met zonnepanelen en een warmtekrachtkoppeling, en waar energie wordt opgeslagen in batterijen en een warmtebuffer. Eerst worden de dimensies bepaald van de apparatuur, gebaseerd op data van opgewekte en verbruikte energie in de wijk, voor verschillende weken verspreid over een jaar. De tweede stap is een simulatie van de wijk over een heel jaar, de resultaten van simulaties van verschillende scenario's worden gepresenteerd, waarbij een vergelijking wordt gemaakt van de DoA (de mate van autarkie) van elk scenario. De resultaten wijzen uit dat het mogelijk is om de wijk (bijna) autarkisch te laten werken door apparatuur van de juiste dimensies en geavanceerde controle toe te passen. Op deze manier is het mogelijk om een DoA van $99.1 \%$ te bereiken, dat betekend dat gedurende het hele jaar slechts minder dan $1 \%$ van de verbruikte energie geïmporteerd moet worden van buiten de wijk. Vervolgens worden de methoden ook toegepast in een studie van de wijk Markluiden in Gelderland. De resultaten wijzen in dit geval uit dat een DoA van $91 \%$ bereikt kan worden over het hele jaar. 
De derde bijdrage betreft de Zeezoutbatterij, een nieuwe accu die momenteel ontwikkeld wordt bij Dr Ten B.V. De Zeezoutbatterij is in het bijzonder geschikt voor stationair gebruik, bijvoorbeeld in een huis of als buurtbatterij. In die rol is de Zeezoutbatterij een alternatief voor bijvoorbeeld Loodzuur en Lithium-ion polymeer batterijen. Er wordt een gedetailleerde beschrijving van de batterij gegeven, en de voor- en nadelen worden besproken. De voordelen zijn o.a. dat er hoofdzakelijk milieuvriendelijke en duurzame materialen gebruikt worden in de batterij, en dat de Zeezoutbatterij slechts minimale risico's voor de gezondheid en veiligheid met zich meebrengt in vergelijking met Loodzuur en Lithium-ion polymeer batterijen. De nadelen zijn o.a. dat de verhouding tussen capaciteit/gewicht en capaciteit/volume lager liggen in vergelijking met de eerdergenoemde alternatieven. Verder wordt een casus besproken waarbij de Zeezoutbatterij geintegreerd is in echte huishoudens. Ook wordt besproken hoe dendrietvorming aan de batterij anode tegengegaan kan worden, dit was één van de problemen die aangepakt moesten worden tijdens het ontwerp van de batterij. 


\section{DANKWOORD}

Het gevaar van het schrijven van een dankwoord waarin je mensen persoonlijk aanspreekt om te bedanken voor iets wat veel voor je betekend heeft, is dat je mensen vergeet. Daarom wil ik allereerst iedereen bedanken die, op welke manier dan ook, bijgedragen heeft aan de totstandkoming van mijn proefschrift. Toch zijn er ook mensen die ik persoonlijk wil bedanken voor hun hulp en inzet.

Marnix, zo halverwege 2014 opperde je voor het eerst dat ik maar eens een promotieonderzoek zou moeten gaan doen. Je had een contact opgedaan aan de Universiteit Twente, en die had wel een promotieplaats beschikbaar. Het onderzoek dat ik zou kunnen uitvoeren zou naast een stuk persoonlijke ontwikkeling ook nog eens voordelig zijn voor Dr Ten. We hebben in die tijd een hoop gesproken over de voor- en nadelen, en het kostte behoorlijk wat tijd voordat ik inzag dat een promotieonderzoek best geschikt was voor mij. Ik ben blij dat je destijds zo gehamerd hebt op de voordelen en blij dat ik uiteindelijk toch gekozen heb voor het promotieonderzoek. Ik ben ook blij met de ruimte die je me sindsdien bij Dr Ten hebt gegeven hebt om het onderzoek uit te voeren en te publiceren. Dankjewel!

Gerard, gedurende mijn tijd aan de UT stond je altijd voor me klaar met hulp en advies. Vaak stuurde je me de juiste kant op, naar de juiste vervolgstap voor mijn onderzoek, naar de juiste persoon om mee samen te gaan werken, het juiste journal om in te publiceren en de juiste conferentie om te bezoeken. Je grootste hulp moet het regelen van experimenteerruimte in het Hoge Druk Lab zijn geweest. In het Hoge Druk Lab kon ik de metingen uitvoeren die nodig waren om de voorspellingen van mijn model te verifiëren, wat uiteindelijk een belangrijk deel van mijn publicaties heeft verbeterd. Zonder jouw hulp en advies was ik met mijn onderzoek niet gekomen waar ik nu ben. Dankjewel!

Johann, tijdens de eerste periode van mijn promotie was je vooral op de achtergrond aanwezig. Daar kwam pas verandering in met Powertech 2017 in Manchester (ook wel "Whisky trip part 2"genoemd), het werk dat we daar presenteerden had een meer wiskundig karakter waardoor jij meer betrokken werd. Daarna ben je steeds betrokken gebleven, en ben ik haast blindelings gaan vertrouwen op al je advies voor verbetering van onze publicaties en mijn proefschrift, geschreven in je unieke Hurogliefen. Maar vooral in het tweede gedeelte van 2019, toen het allemaal niet zo lekker liep met het schrijven van mijn proefschrift was je een steun en toeverlaat, en heb je me er doorheen gesleept. Ik ben blij dat je er voor me was. Dankjewel! 
Ook wil ik graag alle leden van de Energiegroep bedanken. Meteen vanaf het begin was de Energiegroep een heel fijne omgeving om in te werken. Allereerst omdat er zoveel mensen met verschillende wetenschappelijke achtergronden (embedded systems, elektrotechniek, wiskunde, astronomie, civiele techniek) samenwerken, dat iemand met een afwijkende achtergrond als chemische technologie niet eens meer opvalt. Daarbij geven al deze achtergronden een verschillende kijk op een problemen wat weer leidt tot vernieuwende en unieke oplossingen. Ook buiten het werk is de Energiegroep een fijne groep mensen, vaak werden er spontaan gezamenlijke activiteiten als sushi eten, barbecueën, Dungeons \& Dragons spelen, enz. georganiseerd. In het bijzonder wil ik Gerwin bedanken. Je stond altijd klaar voor een wetenschappelijke discussie over een te schrijven publicatie, het oplossen van een hardnekkig probleem (zoals met DEMKit) of simpelweg voor het wegwijs maken op de UT. Ook wil ik Richard en Victor bedanken voor de fijne samenwerking in het onderzoek en schrijven van verschillende papers.

Verder wil ik graag mijn collega's bij Dr Ten bedanken voor de fijne samenwerking, zowel gedurende mijn promotieonderzoek als in de jaren ervoor. Diego, we deden samen vooral veel praktisch werk aan de Zeezoutbatterij, altijd was er iets te verbeteren, op te schalen, aan te passen of uit te werken, en in al die stappen vulden we elkaar aan en verbeterden elkaar. Gerrit, hoewel je officieel de verkoper bent, was je ook altijd beschikbaar als batterijmonteur, chauffeur, pakezel, "Icemaker", subsidiemagneet en (soms) boksbal, kortom echt iemand waarop je kunt bouwen!. En Margriet, met je oneindige nuchterheid hield je de rest van ons met beide benen op de grond.

Mijn dank gaat ook uit naar Benno en zijn team technici in het Hoge Druk Lab. Zonder de behulpzame opstelling van Benno en zijn team, of dat nu was door de regels van het lab beetje te verbuigen zodat ik mijn experimenten kon doen, of doordat ik vrij gebruik kon maken van hun (lab)meubilair en materialen die mijn eigen vakgroep niet beschikbaar had, was het praktische gedeelte van mijn onderzoek veel lastiger te realiseren geweest.

Tot slot, en eigenlijk als voornaamste, bedank ik mijn familie. Pap en mam, jullie staan altijd voor me klaar, met woord en daad en vol belangstelling voor mijn werk. Ook als ik in het weekend naar Sassem kom, om tijd door te brengen bij Tjarda, of gewoon op familiebezoek, kan ik altijd bij jullie terecht om te logeren bij "Hotel Mama". Het is ongelofelijk fijn om te weten dat ik altijd weer thuis kan komen in Sassem. En Nini, Joey \& Lena, bedankt dat ook jullie deur altijd voor me open staat.

Bart

Zwolle, voorjaar 2020 


\section{Contents}

1 INTRODUCTION 1

1.1 The energy transition in the Netherlands ........... 1

1.1.1 Mismatch between electricity production and consumption ... 4

1.1.2 Decentralized energy generation .............. 6

1.1.3 Smart microgrids .................. 7

1.2 Problem statement .................... 11

1.3 Outline of this Thesis .................. 13

2 The DiBu-Model, A SIMPle Yet ReAlistic MOdel FOR BATTery State of Charge Prediction $\quad 15$

2.1 Introduction . . . . . . . . . . . . . . 16

2.2 Materials and Methods .................. 18

2.3 Similarities to thermal energy storage . . . . . . . . . . 19

2.4 A comprehensive model for SoC prediction . . . . . . . . 22

2.4 .1 Discharging ..................... 25

$2.4 .2 \quad$ Charging .......................... 26

$2.4 .3 \quad$ Idle . . . . . . . . . . . . . . . . . 27

2.4 .4 Parameter determination ................ 30

2.5 Voltage prediction, a necessary step ............ 31

2.6 SoC predictions . . . . . . . . . . . . . . . . . . 33

2.6.1 Proof of principle with Pb-acid batteries ........... 33

2.6.2 Improvements to the SoC prediction ............ 37

2.6.3 Verification with additional battery types .......... 40

2.7 Conclusions ...................... 44

3 Implementation OF THE DiBu-Model 47

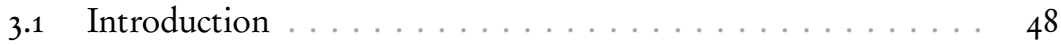

3.2 Background............................ 49

3.2.1 The DiBu-model . . . . . . . . . . . . . . . . . 49

$3.2 .2 \quad$ DEMKit ...................... 50 
3.3 Implementation of the DiBu-model $\ldots \ldots \ldots 51$

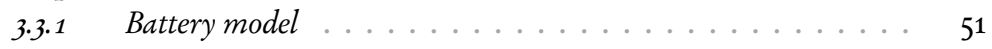

$3.3 .2 \quad$ Battery controller ................... 52

$\mathrm{xvi}$

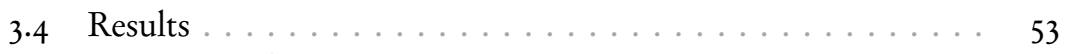

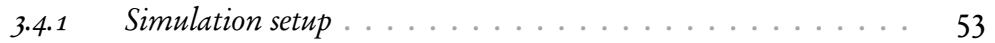

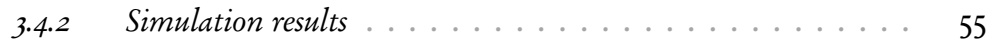

$3.4 .3 \quad$ Validation .......................... 58

3.5 Conclusions ....................... 60

4 THE 16 HOUSES CASE, INTEGRATION OF BATTER IES IN A NEIGHBOURHOOD MICROGRID $\quad 63$

4.1 Introduction . . . . . . . . . . . . 64

4.2 Tools \& Methods ... . . . . . . . . . . . . . . 70

4.2.1 The load profiles ...................... 72

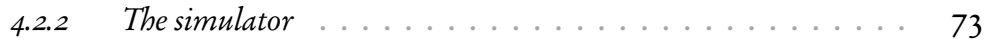

4.2.3 Coordination mechanisms .............. 74

4.3 The layout of the neighbourhood ............ 76

4.3.1 Neighbourbood characteristics ....................... 76

4.3.2 Proper size of relevant equipment .............. 78

4.3.3 Reconsidering the battery size . . . . . . . . . 79

4.4 Simultaneous sizing of the battery, pv-panels and CHP. . . . 82

4.5 Results \& Discussion .................. 84

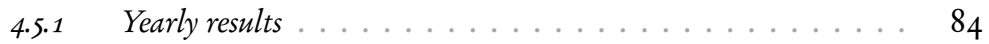

$4.5 .2 \quad$ Specific weeks.................... . . 86

$4.5 .3 \quad$ Planning versus realization .............. 86

4.5.4 The DiBu-model . . . . . . . . . . . . . . . . . 89

4.5.5 In conclusion . . . . . . . . . . . . 90

4.6 Case study: The neighbourhood of Markluiden . . . . . . . 92

4.6.1 Characteristics of the neighbourhood . . . . . . . . . . 92

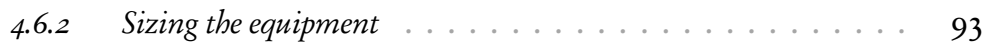

4.6.3 Results ..................... . . 97

4.6 .4 In conclusion . . . . . . . . . . . . . . 100

4.7 Conclusions ... . . . . . . . . . . . . . . . . . 101

4.7.1 The ideal neighbourbood . . . . . . . . . . . . . . 101

4.7.2 The real neighbourbood in Markluiden ... . . . . . . . 103

4.7.3 Both neighbourboods compared .............. 103 
5 The Seasalt Battery 107

5.1 Introduction . . . . . . . . . . . . . . . 108

5.2 Materials \& Methods ....... . . . . . . . . . . . . 109

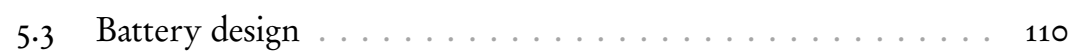

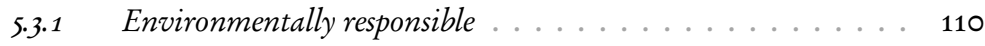

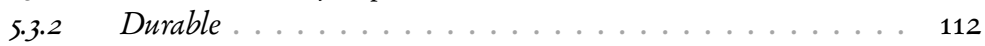

$5.3 .3 \quad$ In Summary . . . . . . . . . . . . . . . 117

5.4 Charge $\&$ discharge behaviour ... . . . . . . . . 118

5.5 State of Charge prediction . . . . . . . . . . . . . . 120

5.5.1 Modifications to the DiBu-model . . . . . . . . . . 120

5.5 .2 Verification of the DiBu-model ............... 122

$5.5 .3 \quad$ In conclusion . . . . . . . . . . . . . 124

5.6 Practical implementation of the Seasalt battery . . . . . . . 124

5.6 .1 The Gridflex project . . . . . . . . . . . . . 125

$5.6 .2 \quad$ Battery system setup . . . . . . . . . . . . . . 125

$5.6 .3 \quad$ Results ..................... 126

5.6 .4 Remaining challenges .................. 128

5.7 Conclusions ... . . . . . . . . . . . . . . . . . 129

6 REDUCTION OF DENDRITE FORMATION AT THE ANODE OF THE $\begin{array}{lc}\text { SEASAlt BatTery } & 133\end{array}$

6.1 Introduction . . . . . . . . . . . . . . . . 134

6.2 Materials and methods ................. 136

6.3 Results and Discussion .................. 136

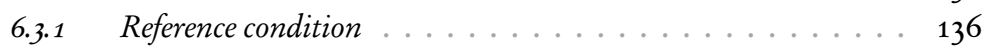

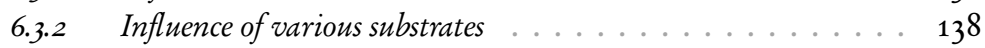

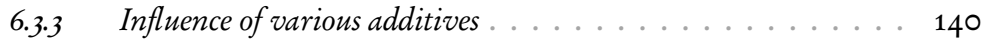

6.3 .4 Combined improvements . . . . . . . . . . . . 143

6.4 Conclusion .......................... 148

7 Conclusion $\quad 151$

7.1 The DiBu-model ... . . . . . . . . . . . . . 151

7.2 The 16 houses case ..................... 153

7.2.1 The ideal neighbourbood . . . . . . . . . . . . 154

7.2.2 The real neighbourbood in Markluiden . . . . . . . . . 155

7.2.3 Both neighbourboods compared.............. 156

7.3 The Seasalt Battery ... . . . . . . . . . . . . . . 156

$7.3 .1 \quad$ Characteristics ... . . . . . . . . . . . . . 157

$7.3 .2 \quad$ Dendrite formation .................. 157 
7.4 Recommendations for future work 158

xviii

A CBS DATA

$\begin{array}{llr}\text { B The DiBu-Model } & 167\end{array}$

B.1 KiBaM model parameters . . . . . . . . . . . . . . . . 167

B.2 Voltage predictions .................... 167

B.3 Tabulated results ........................ 171

$\begin{array}{lll}\text { C The } 16 \text { houses Case } & 177\end{array}$

$\begin{array}{lr}\text { ACronyms } & 181\end{array}$

$\begin{array}{lr}\text { BibliogRAPHY } & 183\end{array}$

$\begin{array}{lr}\text { List of Publications } & 197\end{array}$ 


\section{1 \\ INTRODUCTION}

In recent years the world has seen a considerable climate change, resulting in many environmental problems. Is is widely recognised that these problems are closely related to $\mathrm{CO}_{2}$ emissions resulting from the usage of fossil fuels. As many as 197 countries have agreed, in the Paris agreement [1], to address these problems. The main goal of the Paris agreement is "to keep the global temperature rise this century well below $2{ }^{\circ} \mathrm{C}$ above pre-industrial levels and to pursue efforts to limit the temperature increase even further to $1.5^{\circ} \mathrm{C}$. To contribute to reaching this goal, the Netherlands is currently in the process of implementing the Dutch climate agreement [2]. This is an agreement between Dutch political parties outlining how to achieve the goals set in the Paris Agreement in the Netherlands. In the Dutch climate agreement the temperature rise requirements are translated to $\mathrm{CO}_{2}$ emissions requirements, whereby the goal of reducing the $\mathrm{CO}_{2}$ emissions by 49 $\%$ in 2030 and by $95 \%$ in $2050^{1}$ is set [3]. The agreement encompasses plans, visions and prospective solutions for the reduction of $\mathrm{CO}_{2}$ emissions due to e.g. agriculture, logistics, commercial, personal and public transportation by land, sea and air. However, a major (if not the largest) part of the $\mathrm{CO}_{2}$ emissions is due to the daily domestic, commercial and industrial energy usage for e.g. space-, and water heating, cooking and electricity. Hence a large reduction in $\mathrm{CO}_{2}$ emissions could be achieved by moving away from using fossil fuels as the main energy source, towards using more environmentally friendly and renewable forms of energy that help to decrease $\mathrm{CO}_{2}$ emissions. This is commonly known under the term energy transition.

\subsection{The ENERGY TRANSITION IN THE NetherLANDS}

Changing the source of energy for industrial, commercial and domestic usage from fossil fuels to renewable and environmentally friendly sources is an extensive operation, both financially and practically. To give an indication of the scope of the energy transition, an overview of the energy sources in the Netherlands in

\footnotetext{
${ }^{1}$ Compared to the $\mathrm{CO}_{2}$ emissions as they were in 1990.
} 
2017 is given in Figure 1.1. The figure was compiled using data ${ }^{2}$ acquired from the CBS [4]

Over-ALL

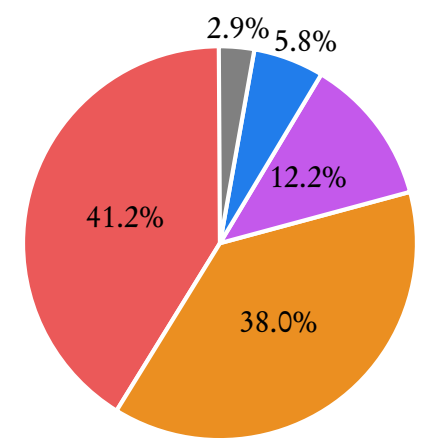

\begin{tabular}{l|l} 
Natural gas & Coal \\
Oil & Renewables
\end{tabular}

\section{RENEWABLES}

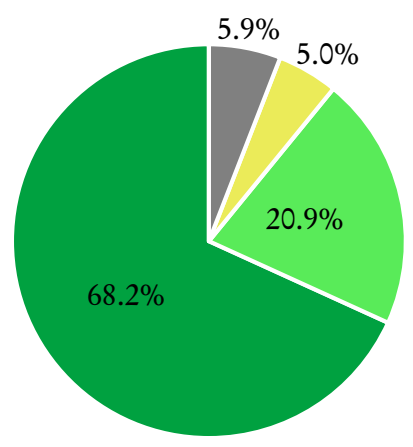

Biomass

Solar

Wind

Figure 1.1: Share of various energy sources used in the Netherlands; left the over-all energy usage; right a breakdown of the "Renewables" fraction of the left pie-chart. Note that the "Other" fractions in both pie-charts have different meanings; left, other energy sources (e.g. nuclear energy); right, other renewable energy sources (e.g. hydro-electric energy)

In 2017 the amount of $3150.5 \mathrm{PJ}$ (or $8.75 \cdot 10^{8} \mathrm{MWh}$ ) of energy was used in the Netherlands [4], including domestic use, industrial use and transportation. In the left pie-chart in Figure 1.1 it is shown that $91.4 \%$ of this energy comes from fossil fuels, e.g. coal, oil or natural gas. Only $5.8 \%$ comes from renewable sources. In the right pie-chart in Figure 1.1 the shares of the various renewable energy carriers are shown. Of the renewable energy used in the Netherlands $68.2 \%$ comes from biomass. It is important to note that by using biomass as a fuel still $\mathrm{CO}_{2}$ is emitted [5], however, this is equal to the amount of $\mathrm{CO}_{2}$ that was taken up by the biomass (e.g. trees and plants) while it lived and grew, causing no net increase of $\mathrm{CO}_{2}$. As such, using biomass does not increase $\mathrm{CO}_{2}$ problems, but it does not decrease them either [6]. The other $31.8 \%$ of renewable energy (or $1.2 \%$ of the total), is made up by wind, solar and other sources that do not contribute to the $\mathrm{CO}_{2}$ emissions.

In the upper graph of Figure 1.2 the yearly energy usage in the Netherlands, from 1990 to 2017, divided in different energy carriers, is displayed. As before the data was acquired from the CBS [4]. Since 1990 the total yearly energy usage

\footnotetext{
${ }^{2}$ The used data of 2017 was the most recent data available. The complete data-set used to compile the pie-charts is included in Table A.1 in Appendix A.
} 
has been stable around $3000 \mathrm{PJ} /$ year, however, there has been a slight decline since 2010. From the lower graph of Figure 1.2 it is clear that the share of energy from renewable sources has steadily increased from 31.6 PJ in 1990 to 181.7 PJ in 2017 , or from $1.1 \%$ to $5.8 \%$ of the total energy usage. However, this implies that also in 2017 still only a minor part of the energy used in the Netherlands came from renewable sources, and that in the 27 years prior to 2017 the share of energy from renewable sources has only increased marginally. Hence, there is still a challenging task to increase this share further to reach the goals set in the Paris agreement [1].

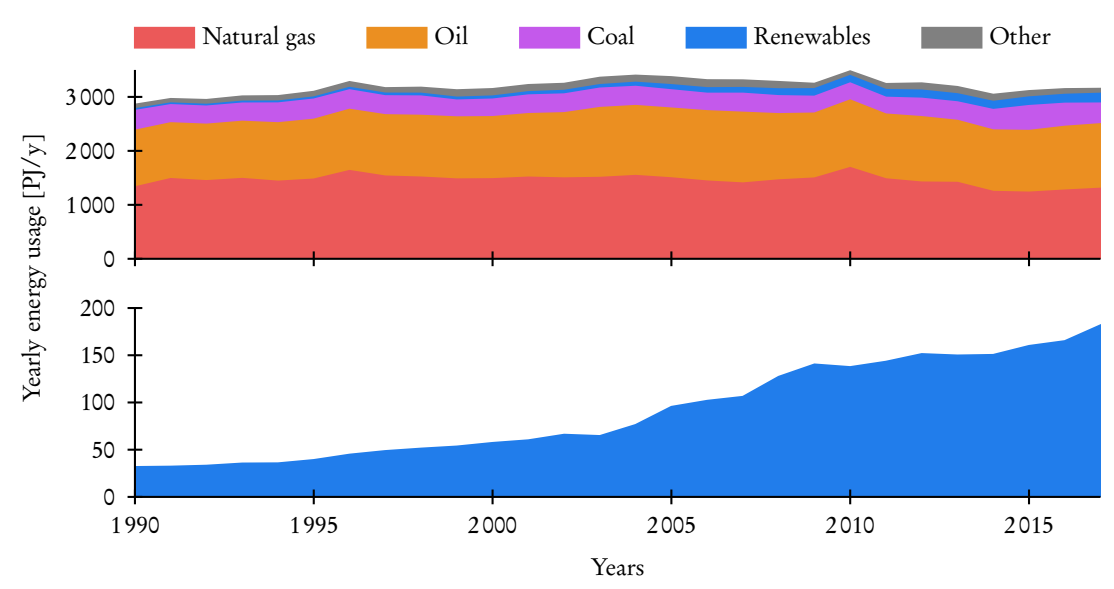

Figure 1.2: Yearly energy usage in the Netherlands, divided by energy carrier.

Next to the above, there is also a second challenge to consider. As indicated in the left pie-chart in Figure 1.1, the largest part of the energy sources used in the Netherlands, (41.2 \%), was in the form of natural gas. Based on the presence of natural gas, the Netherlands has developed an extensive natural gas distribution grid, to which most residential areas, businesses and industries are connected. The gas is used for (space) heating as well as for hot tap water and for cooking [7]. Hence, currently most residents, businesses and industries in the Netherlands are dependent on natural gas. One of the intended steps in the energy transition in the Netherlands is to drastically reduce the usage of natural gas industrially, commercially and domestically. But the most obvious approach, to switch to all electrical appliances is a challenging and probably costly process, for the end users as well as the network operators as the national electrical grid in the Netherlands was not designed for the resulting increase in electricity usage $[8,9]$.

Several possible plans and approaches for the energy transition have already been presented $[10,11]$. The proposed solutions include reducing the energy demand for existing (residential) buildings by e.g. providing these buildings with improved thermal insolation and more efficient heating systems. Parallel to reducing the energy demand, there are also plans for significantly increasing the share 
of renewable and environmentally friendly energy, e.g. by constructing wind farms (both on and off shore) and solar farms or by introducing various new techniques of harnessing hydro-power. Note, that the mentioned measures are only a few examples of many possible technologies. Many of these measures include or need, in some form or another, the storage of electricity [2].

\subsubsection{MISMATCH BETWEEN ELECTRICITY PRODUCTION AND CONSUMPTION}

As stated in the previous section, many of the plans for increasing the share of renewable and environmentally friendly energy include electricity storage. This is the case because for electricity suppliers one of the most important considerations is meeting the electricity demands of their costumers at all times. If fossil fuels are used, meeting the electricity demand is usually not very difficult as currently fossil fuels are readily available. It comes down to simply using more fuel when the electricity demand increases, and using less fuel when the demand decreases. However, when using sustainable energy sources like e.g. solar or wind energy this is not so straight-forward anymore. For instance, electricity generated from sunlight using PV-panels is dependent on the amount of sunlight that actually reaches the PV-panels $[12,13]$. This amount is dependent on factors that can not be controlled, e.g. the time of the day (the sunlight is more intense during the afternoon than during the morning or the evening and during the night no sunlight reaches the PV-panels), the time of the year (the intensity of the sunlight is less during the winter than during the summer), and the cloud cover. So there is no simple way to increase or decrease the electricity generation using PV-panels when the demand changes. This leads to potential mismatches between the electricity production and demand.

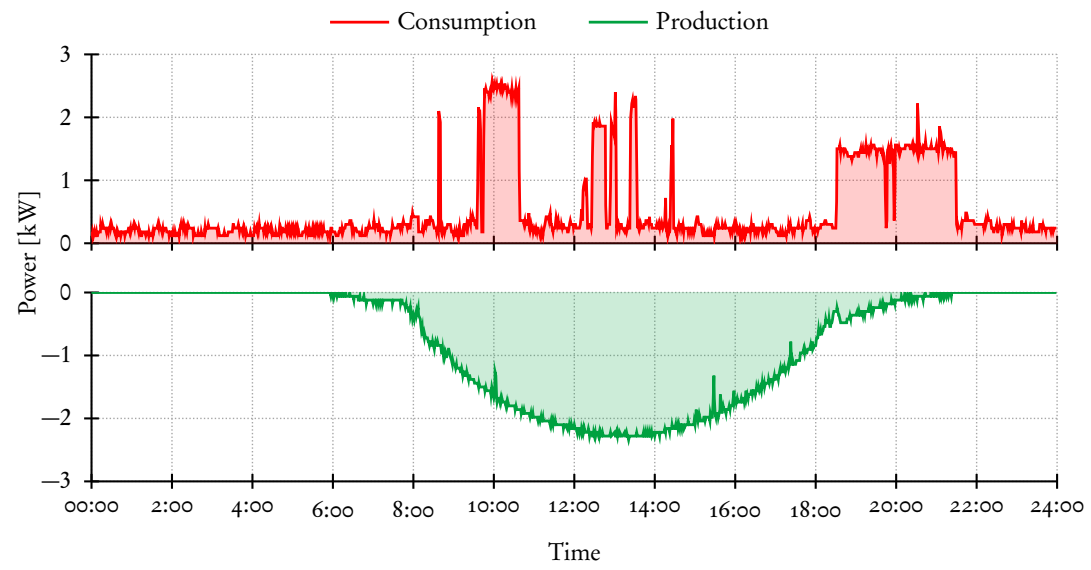

Figure 1.3: Electricity consumption and production (using PV-panels) of a typical house in the Netherlands, measured on the $24^{\text {th }}$ of July 2019 in Heeten. The total consumption is $12.8 \mathrm{kWh}$ and the total production is $18.2 \mathrm{kWh}$. 
To illustrate this, Figure 1.3 shows an example of the power consumed and generated by a typical household in the Netherlands. The data was measured on Wednesday the $24^{\text {th }}$ of July 2019 in Heeten, as part of the Gridflex project. The electricity consumption is structured quite simply, as shown in the upper graph in Figure 1.3. There is a base level of electricity consumption by devices that are always on, e.g. a refrigerator, a TV on stand-by or a boiler. Between 9:00 and 11:0o there is a first peak in electricity consumption, likely to be caused by people making coffee, cooking breakfast, watching TV or using a blow-dryer. During the afternoon there are some additional peaks, possibly a washing machine being switched on, coffee being made or someone using a vacuum cleaner. And in the evening, between 19:00 and 22:00 there is again a large peak of electricity usage, likely from people cooking dinner, using a dishwasher, watching TV, charging appliances or using a computer. The total electricity usage amounts to $12.8 \mathrm{kWh}$, nothing out of the ordinary for a Wednesday in the summer, as the average daily electricity usage, for a 4 person household, in the Netherlands is $12.3 \mathrm{kWh} /$ day [14]. On the other hand, the total amount of electricity generated on this day is $18.2 \mathrm{kWh}$, since this particular day was near-perfect for generating electricity using PV-panels.

Simply looking at the numbers $12.8 \mathrm{kWh}$ consumed and $18.2 \mathrm{kWh}$ produced it might be concluded that on this particular day this household would be able to generate enough electricity using PV-panels to meet its own electricity demand, and even export 5,4 kWh to the grid. However, if the graphs in Figure 1.3 are also considered, it becomes immediately clear that electricity is not always consumed when it is produced and vice versa. During the period between 9:00 and 11:00 the consumption is only partially covered by the production, during the period between 14:00 and 19:00 almost no electricity is consumed while the production is very high, and the opposite is the case between 19:00 and 21:00 where there is a large electricity consumption but almost no production. This leads to a clear mismatch between electricity production and consumption.

Electricity produced using the wind is another example of a renewable resource that cannot be controlled. Windmills or turbines only produce electricity when the wind speed is within a specific bandwidth, fast enough to ensure reliable production, yet slow enough so the equipment does not sustain damage. However, electricity is also needed on stormy or windless days, i.e. when the wind speed is not in the needed bandwidth. So again, a mismatch between electricity production and consumption could occur.

The solution to the problem of a mismatch between electricity production and consumption seems simple: store the electricity. By using an electricity storage of sufficient capacity it is possible to store electricity whenever it is being generated, and to use the electricity whenever there is a demand for it. To illustrate this, Figure 1.4 shows an expansion of the example discussed in Figure 1.3. The upper graph in Figure 1.4 shows the net interaction with the grid between 14:00 and 24:00, (i.e. the sum of consumption and production). The middle graph shows 
the resulting net interaction with the grid when electricity storage is applied. More specifically, electricity is stored between 15:00 and 18:00, when there is a high production and a low consumption and the stored electricity is then used between 18:00 and 22:00 when there is a low production but a high demand. The corresponding amount of stored electricity is given in the lower graph. Between 15:00 and 18:00 4.0 kWh of electricity is stored, the stored electricity is then used between 18:00 and 22:00. This simple example shows that electricity storage can help reducing electricity import from the grid.
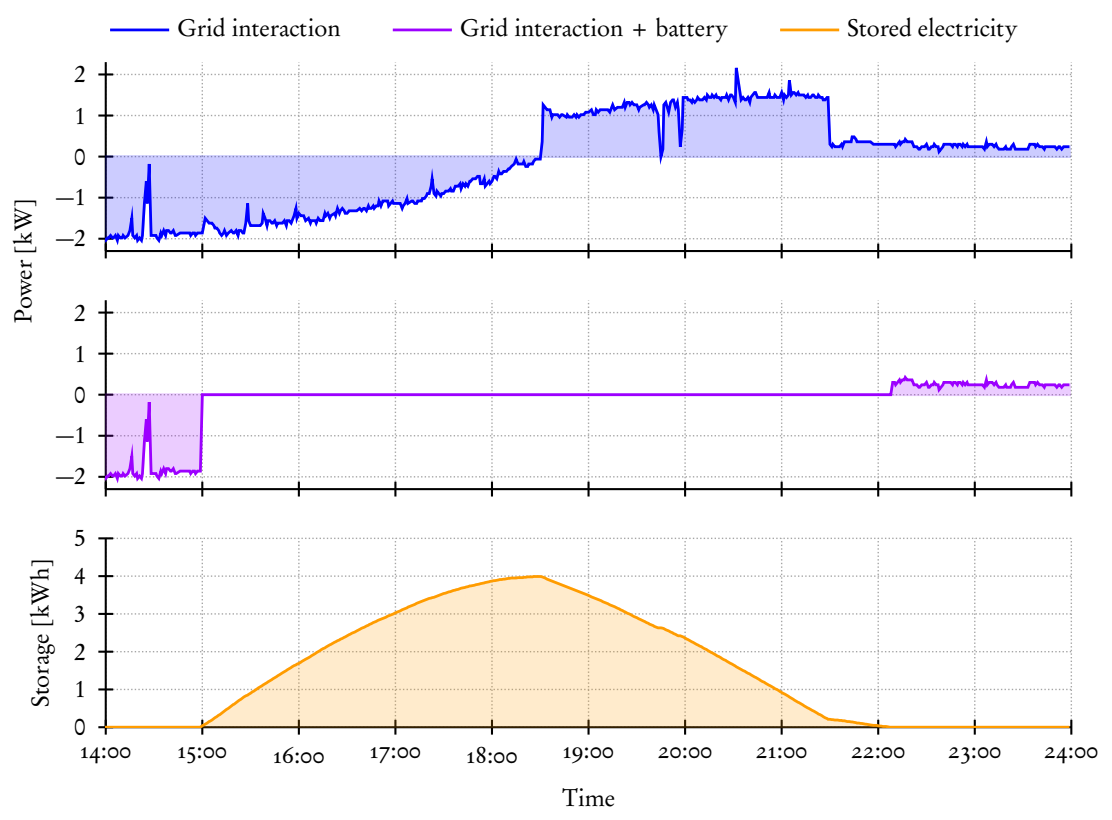

Figure 1.4: Grid interaction between 14:00 and 24:00 of the house featured in Figure 1.3 without battery (upper graph) and with battery (middle graph). Note, that positive values signify import from the grid, negative values export to the grid. The lower graph depicts the stored electricity.

Note that, electricity can be stored in various ways: mechanically (e.g. by using a flywheel or a reservoir), electrically (e.g. using a capacitor), chemically (e.g. via hydrogen) or electrochemically (e.g. using a (flow) battery) [15]. However, not all types of electricity storage are suitable for usage in a house or on a neighbourhood level, e.g. due to scaling or safety issues. One type of electricity storage that is particularly suitable in these cases is: batteries.

\subsubsection{DECENTRALIZED ENERGY GENERATION}

Next to the increase in usage of renewable energy sources, also the decentralization of energy generation is an ongoing trend in the Netherlands [16]. The 
example in the previous section (see Figure 1.3) of a household using PV-panels to generate electricity to meet (part of) its electricity demand is an important example of this trend. More and more PV-panels are added to residences and the amount of electricity generated by PV-panels in residences in the Netherlands has increased from $\sim 180 \mathrm{MWh}$ in 2012 to $\sim 2300 \mathrm{MWh}$ in 2018 , and there are no signs that this increase is slowing down [4]. Other examples include combined heat and power generators (CHP's) providing heat and electricity for whole neighbourhoods and windmills providing electricity for whole villages. Most initiatives of decentralized energy generation are initiated by residents themselves and these people in general do not actively seek to place a source of pollution (as in non environmentally friendly generated energy) near their residence and therefore most energy generated decentrally is environmentally friendly and sustainable.

Now focussing solely on electricity, decentralized generation has several benefits if done properly. The most important benefit in the context of the energy transition is obvious that any amount of electricity generated locally using environmentally friendly means does not have to be generated elsewhere by less environmentally friendly means (e.g. gas or coal power plants). However, there are also other benefits. Firstly, if electricity is generated near where it is consumed there is no need to transport this electricity over long distances using an extensive distribution grid. Secondly, if the electricity generated locally is matched closely to the local electricity demand, (i.e. the local electricity demand is met at all times while overproduction of electricity is limited) the interactions with the national electricity grid (i.e. electricity imports and exports) will be greatly reduced. Thirdly, local electricity generation may lead to peak shaving (i.e. a lower peak power demand while no higher peak power is supplied back to the grid) and thus results in less stress and ageing of cables, transformers, substations and other national grid hardware.

Hence, if the amount of locally generated electricity is increased and meets (part of) the local demand in a sensible 3 way, the expansion of the national electricity grid required for the energy transition (see Section 1.1) could be limited or even avoided completely.

\subsubsection{SMART MICROGRIDS}

One way to properly integrate decentralized electricity generation is within a microgrid. As defined by Lasseter [17] "a microgrid is a cluster of micro-sources, storage systems and loads which presents itself to the grid as a single entity". Additionally, microgrids can be used to increase the reliability and resilience of electricity grids or can be used in ares where no national electricity grid is present [18]. If the supply and demand of electricity within a microgrid are closely matched, the

${ }^{3}$ Note that, if decentralized electricity generation is not done properly or in a sensible way, there could be negative effects. E.g. it could lead to a severe mismatch in electricity supply and demand, which in turn can lead to the need for costly expansions of the national electricity grid. 
interaction between the microgrid and the national grid can be greatly reduced. If there are no interactions between a microgrid and the national electricity grid (i.e. the microgrid is disconnected from the national grid), this is considered an islanded microgrid. The size and contents of a microgrid are not covered in the definition, and in general a grid encompassing one house could be considered a microgrid, but the same is true for a neighbourhood of several houses, or a village, or an industrial complex, etc [18]. In this thesis, unless otherwise specified, a microgrid is considered as a grid encompassing a residential neighbourhood consisting of several houses.

Matching electricity supply and demand within a microgrid can be challenging when (mainly) renewable sources like wind and solar are used. On the one hand, electricity only can be generated from wind or solar output under specific circumstances (see Section 1.1.1) which do not necessarily occur whenever there is an electricity demand. Therefore it is likely that times of electricity shortage and excess occur frequently. On the other hand, user comfort must also be taken into account. In general people like to be able to instantly use electricity when desired, e.g. switching on a light when it gets dark or switching on a water cooker when they want tea. Hence, a microgrid in which power shortages occur frequently would be experienced as uncomfortable. One way to overcome this discrepancy and to improve the matching of the electricity supply and demand within a microgrid, accommodating the inclusion of decentralized generation from renewable sources while also taking into account user comfort, is load shifting.

In general, there are two types of appliances: fixed load appliances and flexible load appliances. Fixed load appliances are either always active (e.g. a refrigerator or a central-heating pump) or are activated by the end-user when needed (e.g. a light or a coffee maker). If a fixed load appliance is not active, or can not be activated immediately by the user this is a detriment to user comfort. Flexible load appliances are those appliances that have to be active at some times during the day, but not necessarily immediately (e.g. a washing machine or EV charger). Flexible load appliances may have to finish performing their function before some specified time, but it makes no difference if the function is finished one second, one minute or one hour before that time, as long as it is finished. For example, if an electric vehicle is plugged in at 18:00 and needs to be charged at 7:00 the next day, the charging at full power will take 6 hours. So the charging can be started directly at 18:00 or as late as 1:00 the next day or at any time in between, and the end result is the same: the EV is charged at 7:00. When the charging power can be adapted, there is even more flexibility. Summarizing, a flexible load appliance can provide flexibility in electricity usage, thereby these appliances may be activated at times when there is a large local supply of electricity (e.g. through PV-panels) to limit exports to the national grid, and be deactivated when there is a large electricity demand from fixed appliances, to limit imports from the national grid. In short, flexible loads can be adapted and shifted in time to improve the balance between supply and demand in a microgrid. 
A different way to provide flexibility to a (micro)grid is by using electricity storage (e.g. a battery). Opposed to flexible loads, which provide flexibility by consuming electricity at times it is convenient for the microgrid, electricity storage provides flexibility in two directions as it can both consume and provide electricity at convenient times, resulting in an even broader potential for load shifting.

To actually improve the balance between electricity supply and demand in a microgrid, it is important to have information on when the flexibility provided by a battery or flexible load should be applied. If the microgrid is very simple (e.g. one house with one inhabitant, PV-panels and one flexible load appliance) the balance between electricity supply and demand might be improved by just using common sense and applying load-shifting manually, (i.e. determining when the inhabitant uses the least amount of electricity, when the largest amount of electricity is produced, and then activating the flexible load appliance at that time) to achieve the desired effect. However, this is not as simple as it looks, as for instance the production of a PV-panel is not that simple to determine since it is weather dependent. More complex microgrids (e.g. one house with multiple inhabitants, multiple flexible load appliances and PV panels) require more careful planning and automated (time delayed) activation of flexible load appliances to achieve an optimal (or just improved) balance between electricity supply and demand. To create such a planning and control a Home Energy Management System (HEMS) can be used [19].

A HEMS is a system that provides services to monitor and manage electricity generation, storage and consumption in a house [19]. If this system also includes some form of automated planning (or decision making), it is referred to as a smart HEMS. The planning can be based on real time measurements (e.g. a battery is charged if the electricity export exceeds some programmed value and the battery is not completely charged), can also include weather forecasts (e.g. if rain is predicted tomorrow between 9:00 and 18:00, the PV panels are predicted to generate less electricity, hence, the battery should be charged before the start of the rain) or include work schedules of inhabitants (e.g. if the inhabitants are at work between 9:00 and 17:00, inhabitants are expected not to use electricity at these times and hence the battery may be charged when the inhabitants are at work). To ensure user comfort, it should be possible to override the planning made by the smart HEMS by the inhabitants (e.g. a flexible load appliance is activated immediately or an inhabitant arrives home earlier than expected and activates fixed load appliances). In this case the smart HEMS should make a new planning to accommodate the behaviour of the inhabitants. A microgrid in which the generation, demand and storage of electricity is managed by smart (home) energy management systems, is referred to as a smart microgrid.

When a smart microgrid of multiple houses is considered, a multi level energy management system can be used to manage the electricity generation, storage and consumption of all houses in the smart microgrid [20]. In this case each 
house has its own HEMS, while all HEMS's in the smart microgrid are managed by a "master controller". There are several possible arrangements for the implementation of such a master controller (see for example [20]) but the function should always be the monitoring and management of all HEMS's in a smart microgrid. Using this overarching electricity management it is possible to coordinate the electricity usage between households (e.g. a battery in House 1 is charged to compensate the electricity produced by PV panels in House 2 or the EV's in Houses 3 and 4 are charged sequentially rather than at the same time) to match the electricity supply and demand on the neighbourhood level (i.e. at the neighbourhood transformer). Note that, in practice there may be legal restrictions to transfer energy between households.

To properly manage the generation, storage and consumption of electricity in a smart microgrid (consisting of multiple houses, flexible loads, batteries and generators), the master controller can make use of predictive and planning based control strategies (for specific examples see $[21,22]$ and for a comprehensive overview see $[23,24])$. The choice of the strategy to use depends on the given smart microgrid, but also on the goals and constraints set by the users of the smart microgrid, which can be completely different for different communities (neighbourhoods) of users. For example, the Aardehuizen community in Olst [25] and the Veldegge neighbourhood in Heeten [26] are both groups of users striving towards operating their neighbourhood less dependent on the national grid. However, hey have different reasons for doing so. The goal of the members of the Aardehuizen community is to use as much as possible of their self-generated, environmentally friendly, sustainable electricity locally. In other words, their goal is to import as little non-sustainable, non-environmentally generated electricity from the national grid. To achieve their goal, the members of the Aardehuizen community accept some loss of comfort. On the other hand, the goal of the inhabitants of the Veldegge neighbourhood is more financially motivated. Their objective is to minimize the highest supply and demand peaks at the neighbourhood transformer while locally generating more environmentally friendly and sustainable electricity. This results in less stress on the local grid hardware, which in turn results in lower tariffs from the grid operator. The inhabitants of the Veldegge do not accept any loss of comfort. In both Aardehuizen and Veldegge, batteries and PV panels are used in the neighbourhood microgrid, but different control strategies are needed to actually achieve their respective goals.

Note, that the concepts and solutions of (smart) electricity microgrids can also be applied to multi-energy systems (MES) [27, 28]. In such a MES, for instance also the heating requirements (e.g. tap-water, space heating) of a neighbourhood could be taken into consideration, if this depends on other source of energy than electricity. Such a neighbourhood could be outfitted with a heat network ${ }^{4}$, heatstorage devices and heat generating devices (e.g. solar thermal collector, CHP's, gas heaters) to supply (the houses in) the neighbourhood with hot tap-water and

${ }^{4} \mathrm{~A}$ heat network can also be considered as a (smart) microgrid. 
space heating. In this case the microgrid could be managed in much the same way as an electricity microgrid to achieve, for instance, the goal of minimizing the natural gas consumption of the neighbourhood [29].

\subsection{Problem STATEMENT}

In the previous section it is discussed that energy storage in general [30-33] and electricity storage in batteries in particular $[15,34]$ may be a perfect solution for some of the problems encountered in the energy transition [2]. Batteries have the potential to effectively use locally generated electricity, leading to less stress on the national grid. Moreover, batteries may be applied in (smart) microgrids to assist in peak shaving, and to provide flexibility needed for reaching the goals of the microgrid [35].

However to steer the storage of electricity, many questions still remain: Which type of storage should be used? Where should the storage be located? What should be the capacity of the storage? How should the storage be used? etc. These types of questions are the focus of this thesis, and they are asked for one specific form of electricity storage: batteries. The central question in this thesis is:

How can electricity storage, in the form of batteries, contribute to the electrical self-sufficiency of neighbourhoods, and increase the usage of locally produced electricity from renewable sources.

Although, this question is central throughout this thesis, it can be considered as a complete research field in itself. And therefore it is very difficult or even impossible to answer this question completely in one thesis. In this thesis, the intention is to shed some light on three aspects of this central question, in order to contribute to the whole chain of battery development: from battery design, to the application of batteries in smart-microgrids, to determining their impact on electricity usage, in the context of the energy transition. In a more practical sense, the question is what is needed to make houses and neighbourhoods more electrically self-sufficient, using sustainable, environmentally friendly energy sources for the generation of their electricity?

The first mentioned aspect is the management of batteries. As indicated in Subsection 1.1.3, predictions of electricity demand, generation and storage can be used in a HEMS to balance the electricity supply and demand, in turn improving the electricity self-sufficiency of neighbourhoods. One aspect of these predictions is to determine how much electricity can be stored in a battery, or taken from a battery, at a future point in time. Hence it is important to have a reliable prediction of the future state of charge (SoC) of a battery. Many models for the predictions of the SoC of various battery types are available [36], but most models are either very complex (likely resulting in computationally expensive calculations in HEMS's) or oversimplified (resulting in idealized results) and 
therefore not suitable for usage in HEMS's. Moreover, most of these models are suitable for only one type of battery, while many different battery types are available. Hence, the first sub-question is:

Is it possible to develop a model for the prediction of the SoC of a battery, suitable for various battery types, which is both simple and accurate enough to be used in simulation tools and HEMS's?

The second aspect is the management of smart-microgrids. As indicated in the previous subsections, the application of decentralized energy generation, energy storage and energy management (e.g. in microgrids) are likely to contribute to increasing the share of locally generated, sustainable and environmentally friendly generated energy. However, as indicated in Subsection 1.1.3, an important aspect in gaining and maintaining support for sustainable, environmentally friendly energy solutions is the comfort of the users. If the electricity and heating demands of users are guaranteed, users will likely not object against, or even will be enthusiastic to adopt sustainable, environmentally friendly energy solutions. Therefore, the second sub-question is:

How can the electrical self-sufficiency of neighbourboods be improved, by making use of batteries and smart control, while the user comfort of the inhabitants is guaranteed?

The third aspect is the battery itself. Many different forms and types of batteries, suitable for electricity storage on the house or neighbourhood level, are available, e.g. lead-acid batteries, lithium-ion batteries and various zinc-based batteries [15]. However each of these types has its own advantages and disadvantages. For example, lithium-ion batteries tend to have high energy to weight, and energy to volume ratios, meaning that much electricity can be stored in small batteries, which is a clear advantage. However, lithium-ion batteries also tend to have a disastrous thermal runaway if damaged $[37,38]$ which may be a reason not to use lithium-ion batteries domestically. Similar considerations can be made for other types of batteries. Hence, it is not straight forward which battery is most suitable for usage at the house or neighbourhood level, and user preference may play an important role in these considerations.

One newly developed alternative type of battery is the Seasalt battery. The Seasalt battery is an innovative battery for energy storage at the house or neighbourhood level, making use of environmentally friendly and sustainable components and technologies, currently under development at $\operatorname{Dr} \operatorname{Ten} B$. V. [39]. However, the Seasalt battery remains largely untested in practical situations. It is likely that still unknown advantages and disadvantages may be observed during practical tests. Therefore, the third sub-question is:

What are the characteristics, advantages and disadvantages of the Seasalt battery, and is the Seasalt battery suitable for electricity storage at the house or neighbourbood level, in the context of smart-grids? 
In the following chapters each of these questions is addressed and the mentioned aspects are discussed in detail.

\subsection{Outline OF This Thesis}

As this thesis deals with three separate yet related sub-questions, it is roughly divided in three parts, which can be read separately.

The first part consists of Chapters 2 and 3. In Chapter 2 a new model called the DiBu-model for battery state of charge prediction is introduced. The chapter explains why the model is needed in the context of the energy transition, how it was conceived and derived, and lastly demonstrates is usefulness for different battery types by comparing simulation results to actual measurements. Chapter 3 deals with the implementation of the DiBu-model in DEMKit, which is a smart grid energy management simulation toolkit. Again, the potential of integrating the DiBu-model within DEMKit is demonstrated by comparing simulations results to actual measurements.

The second part consists of Chapter 4 . In Chapter 4 the integration of batteries in a smart-microgrid is discussed using a case in which soft-islanding of a 16 house microgrid in the Netherlands is explored. Firstly the tools and methods used to determine the proper size and configuration of all equipment in the neighbourhood are discussed. Secondly the results of the sizing are applied in a simulation of an idealized neighbourhood. Finally, the results are compared to the results of a simulation of a real neighbourhood.

The third part consists of Chapters 5 and 6. In Chapter 5 the Seasalt battery, a novel type of electric energy storage, is introduced. The principles used during battery design are discussed and the (dis)advantages and characteristics of the Seasalt battery are outlined. Furthermore, the applicability of the DiBu-model for Seasalt batteries is tested. Finally, the practical implementation of Seasalt batteries in houses within a microgrid is discussed. In Chapter 6 possible solutions are researched and presented for one particular problem encountered during the design of the Seasalt battery: the formation of dendrites at the anode. 


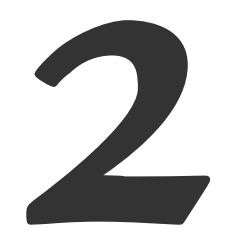

\title{
The DiBu-Model, A Simple YeT REALISTIC MODEL FOR BATTERY StATE OF CHARge PREDiction
}

\begin{abstract}
In this chapter, the DiBu-model, which is a new comprehensive model for the prediction of the state of charge of a battery is presented. This model has been specifically designed to be used in simulation tools for energy management in (smart) grids. Hence, this model is a compromise between simplicity, accuracy and broad applicability. The model is verified using measurements on three types of Lead-acid (Pb-acid) batteries, a Lithium-ion Polymer (Li-Poly) battery and a Lithium Iron-phosphate (LiFePo) battery. For the Pb-acid batteries the state of charge is predicted for typical scenarios, and these predictions are compared to measurements on the Pb-acid batteries and to predictions made using the KiBaM model. The results show that it is possible to accurately model the state of charge of these batteries, where the difference between the model and the state of charge calculated from measurements is less than 5\%. In the same way the model is used to predict the state of charge of Li-Poly and LiFePo batteries in typical scenarios. The resulting predictions of the state of charge are compared to measurements, and it is shown that $i t$ is also possible to accurately model the state of charge of both Li-Poly and LiFePo batteries. In the case of the Li-Poly battery the difference between the measured and predicted state of charge is less than 5\% and in the case of the LiFePo battery this difference is less than $3 \%$.
\end{abstract}

Parts of this chapter have been previously published in [H:2], [H:3], [H:4] and [H:6]. 


\subsection{INTRODUCTION}

On the one hand batteries will become an important ingredient of future energy systems [40]. Examples include using a battery (1) for emergency situations, (2) to store electricity generated by photo-voltaic panels (PV-panel) during the day for usage during the night, or (3) to store electricity at times it is cheap, for usage at times it is expensive. On the other hand, to get insight in the working of future energy systems, more and more simulations of such systems are carried out. For example simulations are used to predict weak points in existing grids [41], to investigate the effect of increasing infeed of renewable energy, to explore the effects of novel electricity pricing mechanisms [42], to explore the possibility of new types of grids [H:1] or to evaluate the effect of integrating new technologies into the system. To be able to accurately estimate, with such simulations, the resulting effects of these settings on the energy usage and power flows in a grid for such simulations, accurate models of all relevant devices and components are needed. As batteries are seen as an important ingredient in the future, this gives rise to the need for such accurate models of batteries.

To describe the behaviour of batteries already a whole set of models and methods are available. Many of these models and methods are suitable for state of charge (SoC) estimation [43], but most of them are only suitable for one specific type of battery, for example lead-acid (Pb-acid) [36] [44]. For Pb-acid batteries, some of these models are even quite accurate. The Schiffer-model [45] for instance is very accurate, and takes most physio-chemical processes that occur in the battery (corrosion, acid stratification, gassing) into account. However, this model requires solving of a large number of equations and (estimated) values for 28 different parameters, many of which are only available to the manufacturers of the battery. The Kinetic Battery Model (KiBaM) introduced by Manwell et al. [46] takes less phenomena into account, and can predict the SoC using only 3 parameters, hereby making use of non-linear equations. Other models that yield high accuracies for the SoC prediction, like the Husnayin method [47] make use of elaborate algorithms and require extensive computations and large data sets to be able to learn how to predict the state of charge of a particular battery. Also for lithium-ion polymer batteries ( $\mathrm{L}$-Poly) many models are available for prediction of the state of charge [48]. For example the Dualfoil model [49] is very accurate, but also very complex to use, as the model requires over 50 input parameters to model the behaviour of a Li-Poly battery, whereby again much of the needed information may only be available to the developers or manufacturers of the battery. The Thevenin model, a type of equivalent circuit model, can be used to predict the SoC of $L i F e P o$ batteries, see e.g. [50, 51]. The model is considered to be very reliable, however the model parameters are difficult to determine and the model itself is complex to use [52]. A more generally applicable method is the Coulomb counting method [53], which can be used to estimate the state of charge of any battery based on measurements. Coulomb counting is an "energy bookkeeping" method, where physical properties and limitations of the battery 
are not taken into account. By adding and subtracting the amount of energy that is charged into and discharged from the battery, the current amount of energy in the battery is estimated, which is then related to the SoC. This method can produce accurate values for the prediction of the current state of charge, but does not provide a prediction of a future state of charge based on the planned actions applied to the battery.

Within the context of smart grids and energy management, the state of the grid and the state of relevant assets (e.g the SoC of a battery) for the near future are important pieces of information as e.g. energy plans have to be submitted to markets a day ahead and deviations are penalized [54]. With the increasing amount of flexibility offered by batteries (both domestic batteries and those found in electric vehicles), such market mechanisms are also becoming increasingly interesting in the residential sector (see e.g. the design of the universal smart energy framework, USEF [55]). Hence, in order to optimize the operation of a smart grid and to be able to participate in the upcoming markets, a scalable and model-predictive control approach is required to benefit from the opportunities provided by these flexible assets in the near future. One example of such a control approach is given by Gerards et al. [21], who introduce the Profile Steering algorithm to devise a power consumption plan in a scalable way for a cluster of devices. The heart of this approach are computational efficient device level planning algorithms. Such algorithms already exist for buffers (including batteries) [56] and electric vehicles [57], however, the presented approaches utilize an ideal battery model (similar to coulomb counting), and thus they do not take the physical characteristics and restrictions of the battery into account. Therefore, the predicted energy and power that the battery can provide may be overly optimistic, resulting in deviations from the planning in reality. Hence, a model is needed that can accurately predict the future SoC while maintaining a low level of complexity to make it applicable for simulations of clusters of hundreds/thousands of distributed battery systems.

In this chapter a new model called the Diffusion Buffer-model for battery State of Charge prediction (DiBu-model) is presented. It has been developed to facilitate sufficiently accurate State of Charge (SoC) predictions, while being simple enough to be used within decentralized energy management tools like e.g. TRIANA [58, 59], GridSpice [60] and DEMKit [20, 61]. The name Diffusion Buffer model for battery SoC prediction was chosen because the idea for this model came from a model designed to estimate the SoC of a heat-buffer [2, 3]. The DiBu-model can be used to predict the effect of a sequence of actions for several intervals in the future (charging or discharging the battery) on the state of charge of a battery. Moreover the DiBu-model is more generally applicable, meaning that it has been designed to model the behaviour of various battery types. It is based on a model for the prediction of the SoC in thermal energy storages, developed by van Leeuwen et al. [62]. The idea of the DiBu-model is first described in [H:2], where the similarities between thermal energy storage and electrical energy storage are discussed; and where the first version of the model is presented. 
In that paper, also some difficulties and problems of the model are pointed out. In [H:3] these problems are addressed, and an improved model is presented. Also first results of the predictive capabilities of the model are presented. A broad analysis of the predictive capabilities of the DiBu-model and a demonstration of its applicability on various types of batteries was presented in an article in the journal Energy [H:6]. This chapter is both a consolidation and an expansion of these publications.

Firstly, in Section 2.2 the equipment and batteries used in this chapter are discussed. Secondly, the similarities between thermal and electrical energy storage, which are at the basis for the DiBu-model are discussed in Section 2.3, while the actual model is outlined in Section 2.4. Thirdly, a thorough verification of the model is presented. Section 2.5 deals with the intermediate step of predicting the battery voltage, while the actual State of Charge predictions are presented and verified in Section 2.6. Lastly, the conclusions are discussed in Section 2.7.

\subsection{Materials ANd Methods}

In the following the measurements on lead-acid batteries are performed using a Vencon UBA 5 battery analyzer [63], under standard conditions. The Vencon UBA 5 battery analyzer has a voltage accuracy of $\pm 0.2 \%$ and a current accuracy of $\pm 0.5 \%$. The measurements on Li-Poly and LiFePo batteries are done on a Cadex C800o battery analyzer [64], under standard conditions. Both the Vencon $\mathrm{UBA}_{5}$ and the Cadex C8000 battery analyzer are multi-purpose devices, used to measure the voltage, current and temperature, and to provide the load and charge. Using either device, a sequence of charging, discharging and resting steps can be programmed, the analyzer then executes these steps and records the applied current and resulting voltage and temperature. The Cadex C8000 battery analyzer has a voltage accuracy of $\pm 0.1 \%$ and a current accuracy of $\pm 0.25 \%$. The parameters $\alpha, \beta, \gamma$ and $\delta$, as well as the parameters necessary for the application of the KiBaM model are determined using the results of at least four separate measurements on the relevant battery. The lead-acid batteries used for this work are commercially available. The Conrad battery, is a Conrad CP672 valve regulated lead acid battery, the Yuasa battery is a Yuasa NP7-6 valve regulated lead acid battery and the Multipower battery is a MP7-6S leadacid battery. The Li-Poly and LiFePo batteries are Dan-energy batteries, also commercially available. All measurements are carried out within safe operating limits (voltage, current and temperature) as supplied by the battery-manufacturer to ensure that the batteries are not damaged. 


\subsection{Similarities TO THERMAL ENERGy STORAGE}

Although thermal energy storage and electrical energy storage (i.e. a battery) are quite different by nature, there are some similarities between the two technologies. A schematic representation of the application of a thermal storage device and a battery is given in Figure 2.1. Parts specific to thermal energy storage are indicated in red while parts specific to the electric energy storage are indicated in green.

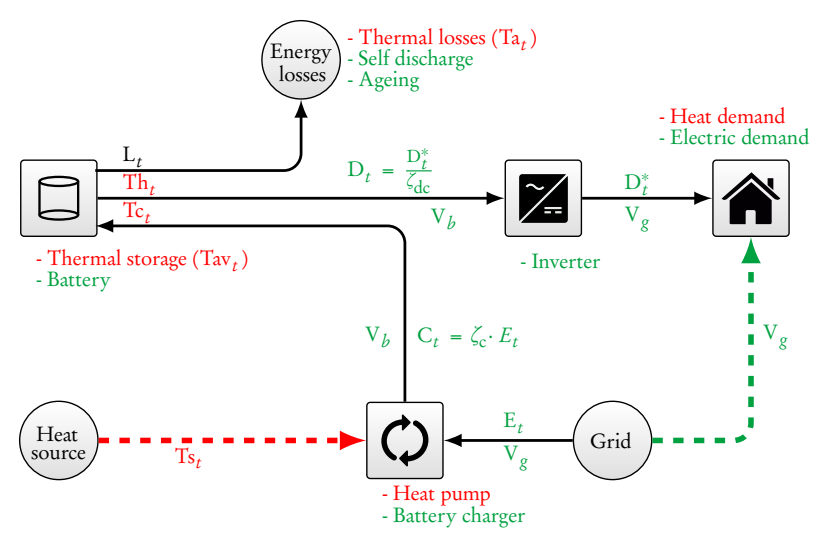

Figure 2.1: Schematic representation of the energy charging and discharging model. Thermal storage processes are indicated in green, electric storage processes in red, connections used in both processes are indicated in black.

In the case of electrical energy storage the battery charger transforms alternating current electric energy $\left(E_{t}\right)$ at a voltage appropriate to the grid $\left(V_{g}\right)$ into direct current energy $\left(C_{t}\right)$ at a voltage appropriate to the battery $\left(V_{b}\right)$, and charges the battery. For discharging, the inverter transforms direct current energy $\left(D_{t}\right)$ from the battery into alternating current energy at an appropriate voltage for the grid $\left(V_{g}\right)$ towards the demand $\left(D_{t}^{*}\right)$. Efficiencies of the charger and inverter are signified as $\zeta_{c}$ and $\zeta_{d c}$ respectively. A small fraction of the stored energy is lost $\left(L_{t}\right)$ by transformation into heat and the capacity of the battery decreases in time due to degradation and ageing. Generally, the electric demand can also be supplied directly from the grid.

In case of a thermal storage, the charger may be an electric heat pump which uses electric energy $\left(E_{t}\right)$ to transform thermal energy from a low temperature source $\left(T_{s}\right)$ to a higher temperature $\left(T_{c}\right)$. Water from the heat pump $\left(T_{c}\right)$ enters the storage while water with a high temperature $\left(T_{b}\right)$ is directly supplied from the storage to the demand. The storage loses a small energy fraction $\left(L_{t}\right)$ due to the temperature difference between the average storage temperature $\left(T_{a v}\right)$ and ambient temperature $\left(T_{a}\right)$. Finally, pipe losses cause a minor difference between thermal energy supplied by the storage $\left(D_{t}\right)$ and the real demand $\left(D_{t}^{*}\right)$. 
Discharging a thermal storage device in general is done by an outlet at the top and inlet at the bottom. The cold water entering the storage at the bottom replaces the hot water further from the outlet at the top and mixes with warmer water within the storage in the bottom region. This effect is influenced by the discharge flow rate. The higher the flow rate, the more mixing will occur.

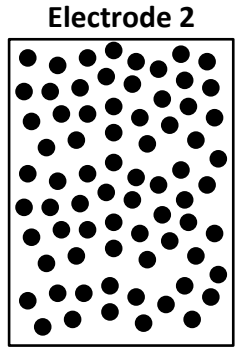

Electrode 1

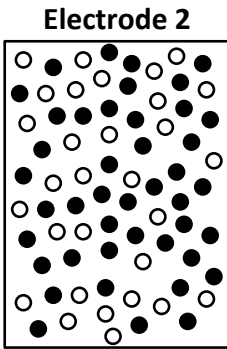

Electrode 1

(a)

(b)

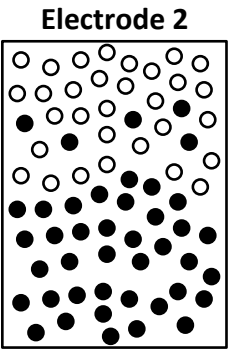

Electrode 1

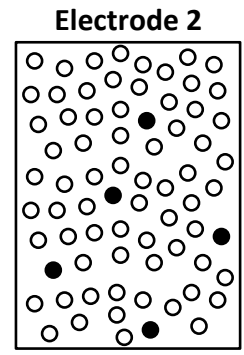

Electrode 1

(d)

Figure 2.2: Schematic representation of the rate capacity effect in a battery. $a$ ) The battery is fully charged. $b$ ) The battery is discharging slowly. $c$ ) The battery is discharging fast. $d$ ) The battery is fully discharged.

A battery to store electrical energy can be described similarly, see Figure 2.2. Generally, when a battery is charging, a reaction takes place at one of the electrodes (electrode 1) creating a compound in which the energy is stored (the black compound). When the battery is fully charged the compound containing the energy is present everywhere in the battery (Figure 2.2a). When a battery is then discharged the compound containing the energy has to physically move to the other electrode (electrode 2) where another chemical reaction takes place creating another compound (the white compound) while releasing the energy. The concentration of the black compound at electrode 2 represents the voltage of the battery. So in other words if the battery is discharged, the concentration of the black compound, and thus the voltage drops until there is too little of the black compound left at electrode 2 to continue discharging. If such a situation is achieved, the battery is discharged (see Figure 2.2d).

If the battery is discharged slowly (i.e with low discharge current) the white compound stays well mixed with the black compound. When $50 \%$ of the black compound has been used, (see Figure 2.2b) the concentration of the black compound at electrode 2, and thus the voltage, is lower then when the battery is fully charged. If the battery is discharged fast (i.e with high discharge current) the black compound is used faster than the mixing occurs (see Figure 2.2c), creating a layer of the white compound that limits access to electrode 2 for the black compound. When $50 \%$ of the black compound has been used in this case, the concentration of the black compound at electrode 2, and thus the voltage, 
is much lower than when the battery was discharged slowly. This process is referred to as the rate capacity effect.

There are also similarities between the quantities and magnitudes in which both storage processes are mostly expressed:

Thermal energy storage

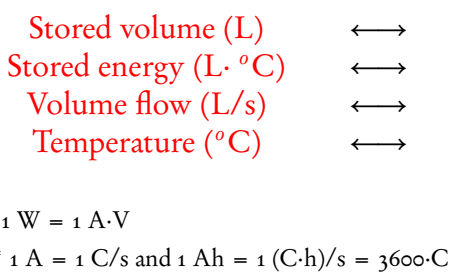

Electric energy storage

Stored capacity $(\mathrm{Ah})$

Stored energy $(\mathrm{Wh})^{*}$

Current $(\mathrm{A})^{* *}$

Voltage $(\mathrm{V})$

The "amount of stored energy" is the stored volume times the temperature for thermal energy storage and the stored capacity times the voltage for electric energy storage. The "amount of energy" that is discharged from or charged to the storage device per unit of time, is the volume flow (at a certain temperature) for thermal energy storage and the current (at a certain voltage) for electric energy storage. The "usefulness ${ }^{1}$ of the energy" is the temperature for thermal energy storage and the voltage for electric energy storage.

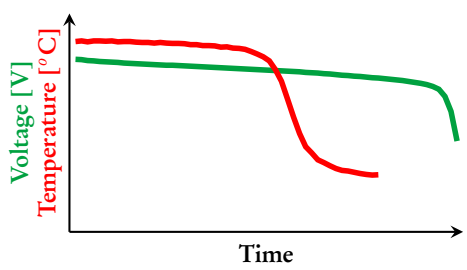

(a) Discharging

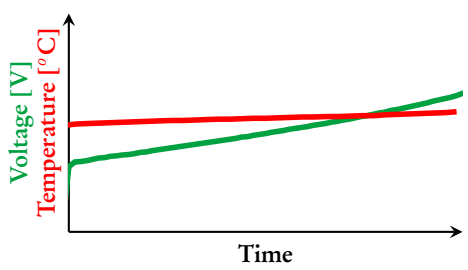

(b) Charging

Figure 2.3: Comparison between a battery (electric energy storage device) and a thermal energy storage device.

Lastly there are similarities between the behaviour of the storage devices themselves. Figure 2.3 shows the general behaviour of a thermal energy storage device (red) and a battery (green) during discharging (Figure 2.3a) and charging (Figure $2.3 \mathrm{~b}$ ). During the discharging of a battery the voltage drops first linearly and at the end there is a steep drop. In the case of discharging a thermal energy storage device the temperature drops, first linearly, then there is a steep drop and then the temperature levels out. Both processes are similar except for the last part.

${ }^{1}$ Usefulness is meant in the way that a thermal supply of $40^{\circ} \mathrm{C}$ is not useful when $80^{\circ} \mathrm{C}$ is demanded but is useful when $30^{\circ} \mathrm{C}$ is demanded. Or in the case of electric energy storage a supply of ${ }_{24} \mathrm{~V}$ is not useful when $230 \mathrm{~V}$ is demanded 
During discharge the temperature of a thermal energy storage device levels out because the outflow (e.g. water) reaches ambient temperature, so there is no further drop. The voltage of a battery would not reach an "ambient voltage" but simply would reach zero Volts if the battery is allowed to discharge completely. However a lower voltage discharge limit is usually used to prevent damage to the battery. In both cases the linear part is the most important; for a battery the voltage during the steep drop would quickly be too low to be useful, while the temperature in the thermal storage device would also quickly become too low to be useful. During charging (Figure 2.3b) of a battery usually the voltage rises linearly until some maximum safe operating voltage is reached, while the temperature of a thermal energy storage device rises linearly until some maximum safe operating temperature is reached.

These similarities between thermal and electric energy storage prompted the development of a realistic model for battery SoC prediction based on the model for thermal SoC prediction developed by Van Leeuwen et al. [65].

\subsection{A COMPREHENSIVE MODEL FOR SOC PREDICTION}

The SoC of a battery is the energy currently stored in a battery, divided by the maximum amount of energy that could be stored in the battery (i.e.the capacity of the battery). More precisely, Equation 2.1 is used for the calculation of the state of charge of a battery at time $t\left(\mathrm{SoC}_{t}\right)$, in which $\mathrm{E}_{t}$ is the energy stored in the battery at time $t$ and $\mathrm{E}_{\max }$ the maximum amount of energy that can be stored in the battery.

$$
S_{o} C_{t}=\frac{E_{t}}{E_{\max }}
$$

The amount of energy stored in the battery at time $t$, can be obtained if the amount of energy in the battery at some previous time $t^{\prime}<t$ and the change of energy during the time interval $\left[t^{\prime}, t\right]$ is known (see Equation 2.2). In the equation $\mathrm{E}_{t^{\prime}}$ is the energy stored in the battery at the time $t^{\prime}$ (before time $t$ ), and $\Delta E_{t^{\prime}, t}$ is the change in the amount of stored energy during time interval $\left[t^{\prime}, t\right]$, e.g. due to charging, discharging or energy losses.

$$
E_{t}=E_{t^{\prime}}+\Delta E_{t^{\prime}, t}
$$

Combining Equations 2.1 and 2.2 yields Equation 2.3, an expression for the state of charge at time $t\left(\mathrm{SoC}_{t}\right)$ based on the state of charge $\left(\mathrm{SoC}_{t^{\prime}}\right)$ at time $t^{\prime}$

$$
S_{o} C_{t}=S_{o} C_{t^{\prime}}+\frac{\Delta E_{t^{\prime}, t}}{E_{\text {max }}} .
$$


The change of stored energy in a battery can be calculated using an energy balance of the battery over the considered time period (see Equation 2.4). In this equation the term $\Delta E_{t^{\prime}, t}$ is again the change of energy stored (or accumulated) in the battery, $\Delta C_{t^{\prime}, t}$ is the charged energy, $\Delta D_{t^{\prime}, t}$ the discharged energy, and $\Delta L_{t^{\prime}, t}$ the energy loss, all within time interval $\left[t^{\prime}, t\right]$.

$$
\Delta E_{t^{\prime}, t}=\Delta C_{t^{\prime}, t}-\Delta D_{t^{\prime}, t}-\Delta L_{t^{\prime}, t}
$$

Energy loss is a term which could have many meanings and thus it is not immediately clear what $\Delta L_{t^{\prime}, t}$ means exactly. For the developed DiBu-model three types of energy loss are considered, conveniently referred to as primary, secondary and tertiary energy losses.

- Primary energy losses occur during charging or discharging of the battery. These energy losses are caused by e.g. internal resistance, heating of the battery, or imperfections in the chemical reactions that govern the battery behaviour. These energy losses are part of the behaviour of the battery during charging and discharging, and can be accounted for in the parts of the model that deal with charging and discharging.

- Secondary energy losses also occur during charging and discharging of the battery, but only have noticeable effects over multiple charge / discharge cycles. Examples of this are ageing and degradation of the battery, i.e. in each consecutive charge / discharge cycle a little less energy can be stored in the battery, and a little less of what was stored can be recovered. These effects typically become noticeable after months or years of battery usage. These effects could be taken into account in the $\Delta L_{t^{\prime}, t}$ term, however, as stated in Section 2.1, the considered model is intended to be simple and should be used in predictions over periods of only several days. Therefore the inclusion of predictions for these losses would needlessly complicate the model.

- Tertiary energy losses occur regardless of charging and discharging the battery. Examples of this are losses due to inefficiency's of the charger or inverter, or losses due to self discharging. These losses are considered to be beyond the scope of this model. Inefficiency's of the charger or inverter are covered in other parts of the smart grid simulation software for which this model is primarily intended. Thus, there is no need to include it in this model. Self discharge losses are considered to be beyond the scope of this model because it occurs when the battery is unused for prolonged periods of time, and this is hardly ever part of the simulations. Hence, including predictions for it would needlessly complicate the model.

In short, losses are taken into account in the charging and discharging parts of the model, and do not explicitly have to be included them in the $\Delta L_{t^{\prime}, t}$ term. Therefore, in this approach $\Delta L_{t^{\prime}, t}=0$. 
Note, that a battery can not simultaneously be charged and discharged. Hence, for Equation 2.4, during discharging $\Delta C_{t^{\prime}, t}=0$, and during charging $\Delta D_{t^{\prime}, t}=0$. Moreover, the change in energy stored in the battery during both charging and discharging can be calculated using Equation 2.5 [66]:

$$
\Delta C_{t^{\prime}, t}=\Delta D_{t^{\prime}, t}=\bar{U} \cdot \bar{I} \cdot\left(t-t^{\prime}\right)
$$

in which $\bar{U}$ is the battery voltage during $\left[t^{\prime}, t\right]$ and $\bar{I}$ is the applied or demanded current during $\left[t^{\prime}, t\right]$. The sign of the value of $\bar{I}$ signifies whether the battery is charging or discharging, i.e. $\bar{I}<0$ for discharging and $\bar{I}>0$ for charging. Hence there is no need for separate expressions for the terms $\Delta C_{t^{\prime}, t}$ and $\Delta D_{t^{\prime}, t}$. Note that if $\bar{I}=0$ the battery is neither charging nor discharging, hence it is idle. Combining this with Equation 2.3 for the calculation of the state of charge results in Equation 2.6:

$$
S_{o} C_{t}=S_{o} C_{t^{\prime}}+\frac{\bar{U} \cdot \bar{I} \cdot\left(t-t^{\prime}\right)}{E_{\max }} .
$$

This equation is the basis for the model to predict the SoC in a future point in time $(t)$, as a percentage of the maximum capacity $\left(\mathrm{E}_{\max }\right)$ in Wh, based on the SoC at the current time $\left(t^{\prime}\right)$. More precisely the state of charge $\left(\mathrm{SoC}_{t}\right)$, given as a fraction of the battery capacity, is calculated by adding the change of the SoC during the time interval $\left[\mathrm{t}^{\prime}, \mathrm{t}\right]$ to the previous SoC at time $t^{\prime}<t$ $\left(\mathrm{SoC}_{t^{\prime}}\right)$. The change of the SoC is based on the current $(\bar{I})$ and voltage $(\bar{U})$ in the corresponding time interval $\left[t^{\prime}, t\right]$. To calculate the SoC at some future time $T\left(\mathrm{SoC}_{T}\right)$ starting from an initial SoC at time start $\left(\mathrm{SoC}_{\text {start }}\right)$ a sequence of time points $t_{0}<t_{1}<\ldots<t_{n}$ with $t_{0}=$ start and $t_{n}=T$ is considered in combination with the value of $\mathrm{E}_{\max }$ and the current $\left(\overline{I_{j}}\right)$ and voltage $\left(\overline{U_{j}}\right)$ used during the time

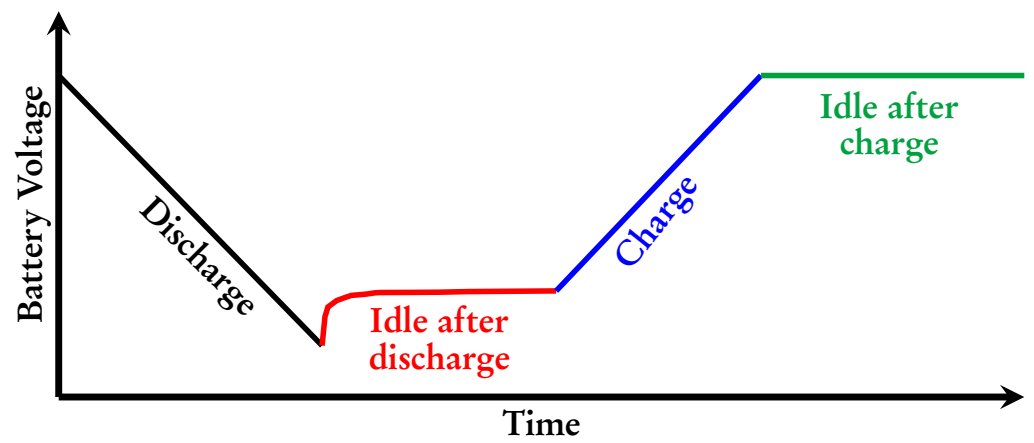

Figure 2.4: Schematic representation of the battery voltage during charge, discharge and idle steps. 
intervals $\left[t_{j-1}, t_{j}\right], j=1 \ldots n$. Hereby the current $\left(\overline{I_{j}}\right)$ corresponds to what is applied to or demanded from the battery in the time interval $\left[t_{j-1}, t_{j}\right]$. Typically the time step $\Delta \mathrm{t}=t_{j}-t_{j-1}$ ranges from 10 to 60 seconds. To calculate the voltages four states of the battery are considered: discharging, idle time after discharging, charging and idle time after charging (see Figure 2.4). Note that the length of the time steps $\Delta \mathrm{t}$ can be varied between states and within states.

For each of these four states, an expression is needed to determine the voltage in such a state. These expressions are discussed in the following subsections.

\subsubsection{Discharging}

To be able to obtain an expression for the battery voltage during discharge, the voltage of two types of batteries during discharge is studied. In Figure 2.5 the voltage during constant current discharge, for a Lead-acid battery and a Lithiumion polymer battery, is displayed.

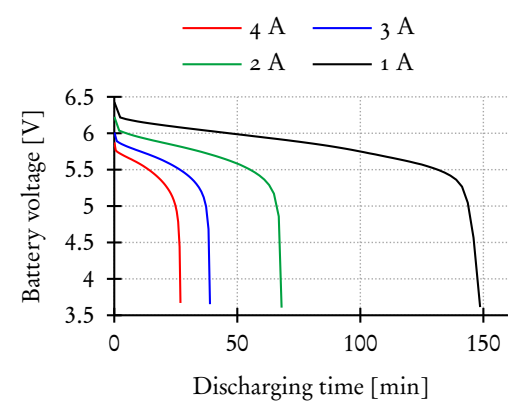

(a) Pb-acid

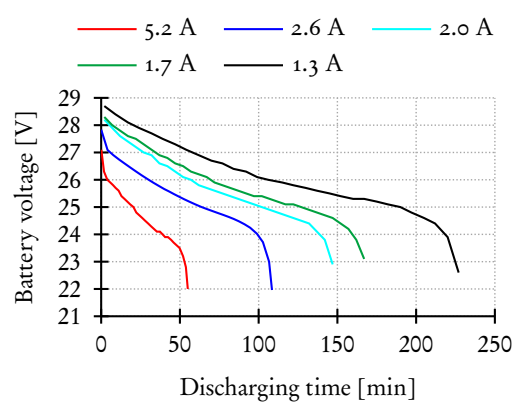

(b) Li-Poly

Figure 2.5: Battery voltage of a Lead-acid battery (a) and Lithium-ion Polymer battery (b) during constant current discharge at various discharge currents.

For both types of batteries roughly the same behaviour is observed; at the beginning of the discharge the voltage drops smoothly at an almost linear rate (part I), while at the end of discharge there is a steep voltage drop (part II). Note that the period of part II is very short compared to the rest of the discharge time. For Figure 2.5 the batteries were discharged long enough to reach a voltage low enough to show the steep drop. However, batteries in general tend to get damaged when the battery voltage is too low [67]. This is caused by unwanted (irreversible) chemical reactions taking place if the battery is discharged too far, with the effect of permanently diminishing the capacity of the battery. Therefore, battery management systems (BMS), typically used in combination with batteries, stop the battery from discharging just before, or at the start of the steep voltage drop. Hence, an accurate prediction of part II of the discharge behaviour has little 
practical value for the desired model and thus will not be taken into account in the model.

As a result, the model for the prediction of the voltage during the discharge state can be specified by a linear approximation of part I of the discharge behaviour. The slope of this line is dependent on the discharge current and the starting SoC but is also specific for a battery type and its capacity. The proposed expression for the change of the voltage during discharge is:

$$
U_{t_{j}}=U_{t_{j-1}}+\frac{\alpha \cdot \bar{I}}{S_{o} C_{t_{j-1}}}
$$

where the voltage $U_{t}$ at time $t$ is calculated from the used current $(\bar{I})$ in time interval $\left[t_{j-1}, t_{j}\right]$, a given constant $\alpha$ dependent on the specific battery and the state of charge at time $t_{j-1}\left(\mathrm{SoC}_{t_{j-1}}\right)$ and the voltage at time $t_{j-1}\left(U_{t_{j-1}}\right) . U_{t_{0}}$ and $\mathrm{SoC}_{t_{0}}$ are known at the beginning of the discharge step, as these are either the starting conditions of the prediction, or the ending conditions of the previous step. The value of $\alpha$ mainly depends on the type of battery (i.e. chemistry, operating voltage, capacity, size, geometry, etc.) but is the same for multiple batteries of the same type. It should also be noted that the value of $\alpha$ is likely to be influenced by the degradation (or ageing) of the battery, because the overall performance of the battery decreases over time [67], i.e., the value of $\alpha$ could change as the battery is used for a long time. However, the influence of the battery degradation on the value of $\alpha$ has not been investigated. The determination of the value of $\alpha$ is further discussed in Section 2.4.4.

\subsubsection{Charging}

The behaviour of the voltage during charging of the same $\mathrm{Pb}$-acid and Li-Poly batteries as used in Section 2.4.1 is analysed to obtain an expression for the voltage behaviour in a charge step. In Figure 2.5 the voltage during constant current charge, for both batteries is displayed.

For both batteries a similar behaviour of the voltage during charging is observed. In both cases the voltage rises in an almost linear fashion, with a slope that is slightly steeper if the charging current is higher. This indicates that for the prediction of the voltage during the charge state, a model based on a linear approximation of the charge behaviour can be used. Note, that the slope of this line is dependent on the charge current but is also specific for a battery type and capacity. The proposed expression for the predicted voltage during charge is:

$$
U_{t_{j}}=U_{t_{j-1}}+\frac{\bar{I}}{\delta}
$$




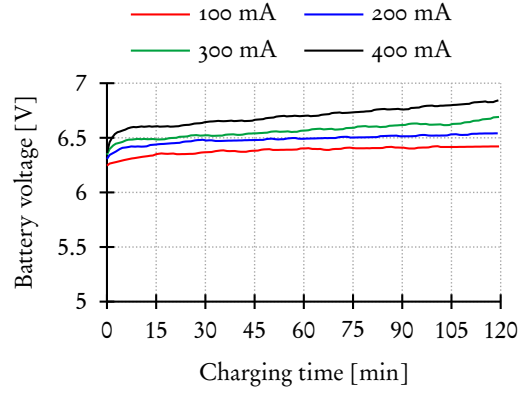

(a) $\mathrm{Pb}$-acid

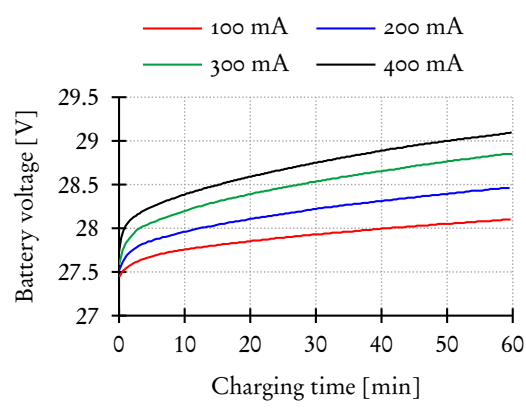

(b) Li-Poly

Figure 2.6: Battery voltage of a Lead-acid battery (a) and Lithium-ion Polymer battery (b) during constant current charge at various charge currents.

where the voltage, $U_{t}$ at time $t$ is calculated based on the voltage $U_{t_{j-1}}$ and the applied current $\bar{I}$, in time interval $\left[t_{j-1}, t_{j}\right]$ and a battery specific constant $\delta . \bar{I}$ is always known at the start of the calculation since it is the current applied to the battery. $U_{t_{0}}$ is also known at the start of the calculation as this is a starting condition or the result of a calculation for the previous time interval. Similarly to the value of $\alpha$ in the expression of the voltage during discharge (see Section 2.4.1), the value of $\delta$ is mainly dependent on the type of battery (i.e. chemistry, operating voltage, capacity, size, geometry, etc.) but is the same for multiple batteries of the same type. Also similarly the value of $\delta$ is likely to be influenced by the ageing or degradation of the battery, but this has not been investigated. The determination of the value of $\delta$ is further discussed in Section 2.4.4.

\subsubsection{IDLE}

As already indicated in Figure 2.4 the behaviour of the voltage of a battery in an idle state is dependent on the operation the battery was performing just before the idle period, thus there are separate expressions for "idle after charge" and "idle after discharge".

The expression for the voltage during an "idle after charge" step is straight forward, as the voltage remains constant after the charging has stopped and the battery is left idle, i.e. if during $\left[t_{j-1}, t_{j}\right]$ the battery was idle and before $t_{j-1}$ the last action of the battery was "charging". The expression for the voltage in this case is simply:

$$
U_{t_{j}}=U_{t_{j-1}}
$$

When a battery is left idle for an extended period of time the voltage will drop eventually due to self-discharge. To the extreme, if a battery is left idle long 
enough, it will completely discharge. However, for most types of batteries the voltage remains constant for days or weeks after charging. As this is well beyond the time frame (hours, days) for which this model is intended, Equation 2.9 should be sufficient for the "idle after charge" state.

The voltage behaviour in the "idle after discharge" state is quite different, as also shown in Figure 2.4. In this state the voltage first rises when the battery is idle. Depending on the SoC of the battery at the end of the preceding discharge step the voltage can rise up even to the starting voltage of that discharge step. Note that the SoC of the battery does not rise when the battery is idle, however, the prediction of the SoC during the next step after the idle period (charging or discharging) is dependent on the starting voltage of that step. Therefore an expression of the development of the voltage during the idle state is required. This is described further in the next paragraph.
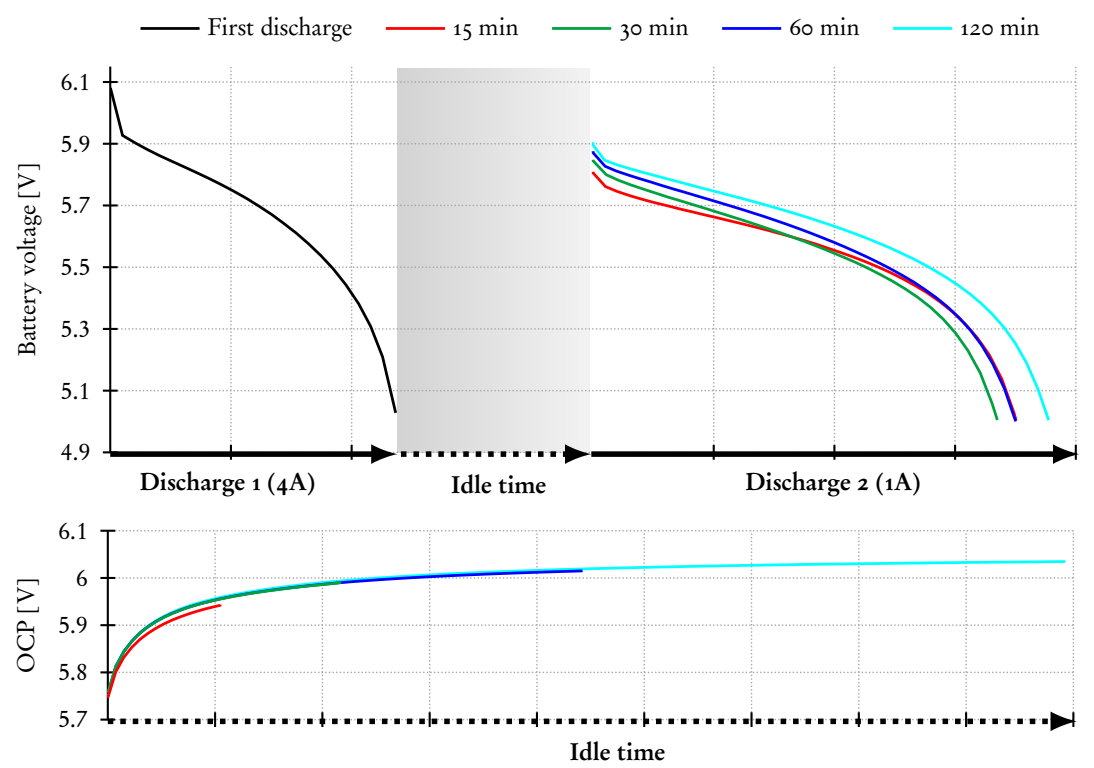

Figure 2.7: Measured voltage during two consecutive discharge steps, and OCP during the idle step, for a $6 \mathrm{~V}, 4 \mathrm{Ah} \mathrm{Pb}$-acid battery with varied idle step times.

In Figure 2.7 the voltage of a (6 V, $4 \mathrm{Ah}$ ) Lead-acid battery during two discharge steps is displayed, where in between the discharge steps the battery was left idle for various periods of time. The voltage during the idle time, displayed in the lower graph of Figure 2.7, is the Open Circuit Potential (OCP). In the first discharge step, the battery was discharged with a discharge current of $4 \mathrm{~A}$ from fully charged to $5 \mathrm{~V}$. In the second discharge step, the battery was discharged with a discharge current of $1 \mathrm{~A}$ to $5 \mathrm{~V}$ again. Note, that during the idle step the voltage is increased sufficiently, for the battery to be discharged again. From the 
lower graph in figure 2.7 it is clear that the OCP during the idle step depends on the length of the idle time.

This effect can be described using an explanation similar to the thermal storage analogy used in Section 2.3. However, note that once mixed, the water in a thermal storage does not recover back to higher temperatures, so there is no direct analogous effect of this part. Figure 2.8 shows a schematic representation of a battery during the process of voltage increase during an idle step.

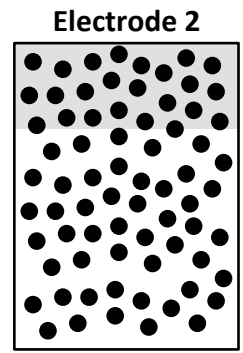

Electrode 1

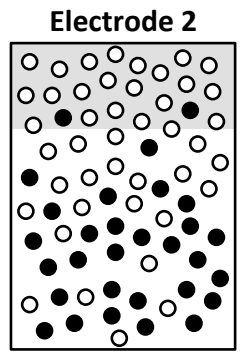

Electrode 1

(a)

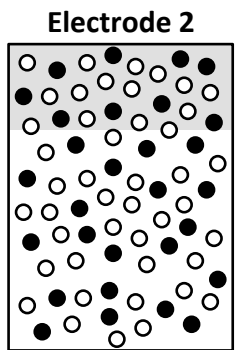

Electrode 1

(c)

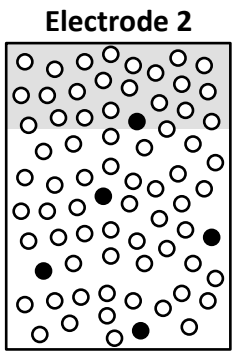

Electrode 1

(d)

Figure 2.8: Schematic representation of the voltage increase during discharging and a time when a battery is idle after discharging. a) The battery is fully charged. b) The battery is discharged fast to $50 \%$ of its capacity, but the voltage has dropped to the minimum allowable condition. $c$ ) The battery is allowed to rest for a period of time, this results in a re-distribution of the black compound. $d$ ) The battery is fully discharged.

Figure $2.8 \mathrm{a}$ shows the battery at a fully charged state, and Figure $2.8 \mathrm{~b}$ shows the battery after being partly discharged (as it would be at the end of the first discharge step in Figure 2.7). The concentration of the black compound at electrode 2 is now low and thus also the voltage is low. Note that the concentration of the black compound near electrode 2 (in the grey area) is lower than the concentration of the black compound elsewhere in the battery. If the battery is then allowed to rest for a period of time (see Figure 2.8c) the black and white compound are properly mixed again, and the concentration of black compound in the grey area and thus the voltage is increased (as it would be at the beginning of the second discharge step in Figure 2.7. Note that the over-all concentration of the black compound in the battery has not changed during the waiting time. However, due to the redistribution of the black compound, the battery can again be discharged (see Figure 2.8d). At the end of the second discharge the concentration of black compound in the grey area and thus the voltage is as low as it was in Figure 2.8b but now the over-all concentration of the black compound is lower.

Taking into account the described behaviour of the OCP, but also keeping in 
mind that the voltage at the start of the following step is the parameter that actually has to be predicted, a first order system approximation for the voltage is:

$$
U_{t}=U_{t_{0}^{\prime}}+\left(U_{\max }-U_{t_{0}^{\prime}}\right) \cdot\left(1-e^{\frac{t-t_{0}^{\prime}}{\tau}}\right)
$$

In which $t_{0}^{\prime}$ is the starting time of the idle step, $U_{t}$ is the resulting discharge voltage of the waiting time at $t$ and $U_{t^{\prime}}$ is the initial voltage at the start of the waiting time. Furthermore $U_{\max }$ is the starting (i.e. highest) voltage of the battery during the preceding discharge step. In a first attempt $\tau$ was assumed to be a constant dependent on the battery type, however, it was determined experimentally that $\tau$ is not a constant, but rather a function of the waiting time. Therefore a linear relation for $\tau$ is introduced, which was experimentally determined to be sufficiently accurate:

$$
\tau=\beta \cdot\left(t-t_{0}^{\prime}\right)+\gamma
$$

In which, as before, $t_{0}^{\prime}$ is the starting time of the idle step and $\beta$ and $\gamma$ are battery specific constants. Substituting Equation 2.11 in Equation 2.10 yields the expression for the voltage during an "idle after discharge" step:

$$
U_{t}=U_{t_{0}^{\prime}}+\left(U_{\max }-U_{t_{0}^{\prime}}\right) \cdot\left(1-e^{-\frac{t-t_{0}^{\prime}}{\beta \cdot\left(t-t_{0}^{\prime}\right)+\gamma}}\right) .
$$

\subsubsection{PARAmeter Determination}

Estimates for the parameters $\alpha, \beta, \gamma$ and $\delta$ have to be determined dependent on battery type, using e.g. the least squares method applied to voltage measurements during the charging and discharging of the battery with a constant current. The measurements necessary to determine the parameters $\alpha, \beta, \gamma$ and $\delta$ are outlined in Figure 2.9. First, to determine the value of parameter $\alpha$ a linear approximation is made of the mostly linear part of the discharge curve (i.e. the part before the steep drop off). The value of $\alpha$ is the slope of that linear approximation (see Figure 2.9a). Parameter $\delta$ is determined in a similar manner, using a linear approximation of the charge curve (see Figure 2.9b). Multiple measurements, using various charge and discharge currents are used to determine the values for $\alpha$ and $\delta$ to ensure accuracy.

To determine the values of parameters $\beta$ and $\gamma$, voltage measurements with two consecutive discharge steps and an idle period in between are used, see Figure 2.9c. The voltage measured during the idle period, however, is not the real battery voltage but the open circuit potential (OCP). In practice the OCP is always higher than the discharge voltage, but here the progression of the OCP 
in time, can be used to determine the voltage at the start of the second discharge step. Again, multiple measurements are done using various discharge currents and idle periods to determine accurate values for the parameters. In a final step the parameters are once more verified by comparing the state of charge calculated from the measurements $\left(\mathrm{SoC}^{\text {meas }}\right)$ and the state of charge calculated using the $\mathrm{DiBu}$-model $\left(\mathrm{SoC}^{\mathrm{DiBu}}\right)$. In the presented case the difference between the SoC ${ }^{\text {meas }}$ and the $\mathrm{SoC}^{\mathrm{DiBu}}$ is hardly visible and the maximum difference is calculated as $0.48 \%$, (See Figure 2.9d).

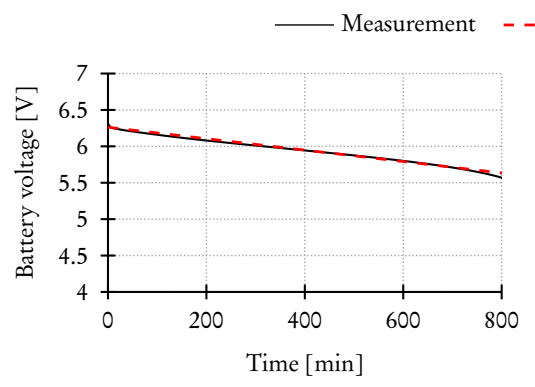

(a) Determination of parameter $\alpha$

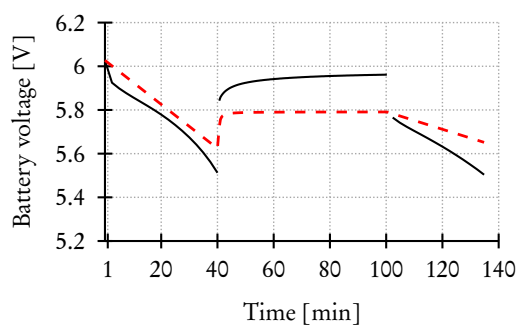

(c) Determination of parameters $\beta$ and $\gamma$

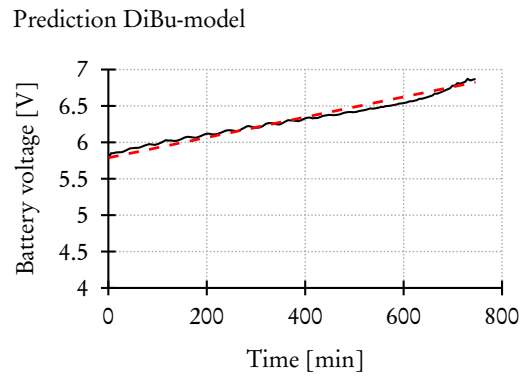

(b) Determination of parameter $\delta$

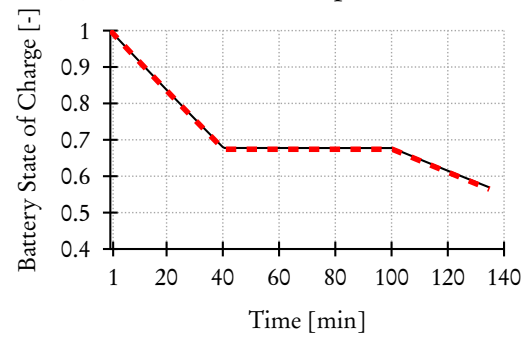

(d) Verification of parameter $\alpha, \beta$ and $\gamma$

Figure 2.9: Measurements used in the determination of parameters $\alpha, \beta, \gamma$ and $\delta$ for a lead-acid battery. Note that the measured SoC in Figure 2.9d is calculated from voltage and current measurements.

\subsection{Voltage PREDiction, A NECESSARY STEP}

In the following the parameters presented in Section 2.4 are determined for the three lead-acid (Pb-acid) batteries, using the model and method outlined also in that section. The three tested batteries have more or less the same specifications, but are made by different manufacturers; Conrad, Yuasa and Multipower, (the batteries are referred to by these names.). The achieved results are presented in Table 2.1. For all three tested batteries, the values for the parameters $\alpha, \beta, \gamma$ and $\delta$ respectively are very similar. Using the parameters in Table 2.1, the DiBumodel given by formulas 2.6 (for the SoC) and 2.7, 2.8, 2.9 and 2.12 (for the 
voltage) is applied to predict the behaviour of the Conrad, Yuasa and Multipower batteries in a typical scenario. More precisely, the voltage and SoC of each battery are predicted during consecutive charge, discharge and idle steps. The applied currents for each step in the scenario are given in Table 2.2.

Table 2.1: Characteristics and parameters determined for the three tested leadacid batteries.

\begin{tabular}{lccc}
\hline & Conrad & Yuasa & Multipower \\
\hline Rated capacity (Ah) & 7.2 & 7.0 & 7.0 \\
Nominal voltage (V) & 6.0 & 6.0 & 6.0 \\
$\alpha(\mathrm{V} / \mathrm{A})$ & $3.030 \times 10^{-5}$ & $3.756 \times 10^{-5}$ & $4.618 \times 10^{-5}$ \\
$\beta(-)$ & 0.268 & 0.249 & 0.218 \\
$\gamma(\min )$ & 2.684 & 2.323 & 0.839 \\
$\delta(\mathrm{A} / \mathrm{V})$ & $2.438 \times 10^{4}$ & $1 ., 727 \times 10^{4}$ & $1.055 \times 10^{4}$ \\
\hline
\end{tabular}

Note, that the prediction of the voltage is not the main goal of the DiBu-model, but a necessary step in the SoC prediction. Therefore only one example of this step is presented here ${ }^{2}$. In Figure 2.10 the measured and predicted voltage of the Conrad battery, under the applied currents is shown. The pattern of the predicted voltage, resembles the pattern of the measured voltage, however, the difference between the predicted and measured voltage is up to 0.54 Volt (or 7.7 $\%$ of the maximum voltage) which seems to be quite large. Furthermore the difference between the prediction and the measurement is largest in discharging steps (Step 5 and 9 in Table 2.2) where the battery is discharged with $1 \mathrm{~A}$, and $0.8 \mathrm{~A}$ respectively. However, as the goal of this model is not to give an accurate prediction of the battery voltage, but rather give an accurate prediction of the SoC this deviation of the voltage on its own is not directly an issue. Therefore, in the next section the SoC predictions are investigated in more detail.

Table 2.2: The charge, discharge and idle steps used in the experiments described in Figures 2.10 and 2.11. To protect the batteries, a maximum cut-off voltage of $6.9 \mathrm{~V}$ and minimum cut-off voltage of $5.5 \mathrm{~V}$ was set. In some steps the cut-off voltage was reached before the step was completed; in these instances the real charge or discharge step length is shorter than indicated in this table. (See also Figures 2.10 and 2.11)

\begin{tabular}{|c|c|c|c|c|c|c|c|c|c|}
\hline Step \# & Type & Current (A) & Length (min) & Total (min) & Step \# & Type & Current (A) & Length (min) & Total(min) \\
\hline 1 & Charge & 0.4 & 420 & 420 & 8 & Charge & 0.2 & 240 & 1455 \\
\hline 2 & Idle & $\circ$ & 15 & 435 & 9 & Discharge & -0.8 & 240 & 1695 \\
\hline 3 & Discharge & -0.5 & 60 & 495 & 10 & Idle & $\circ$ & 30 & 1725 \\
\hline 4 & Idle & $\circ$ & 30 & 525 & 11 & Discharge & -0.5 & 240 & 1965 \\
\hline 5 & Discharge & -1.0 & 60 & 585 & 12 & Idle & $\circ$ & 15 & 1980 \\
\hline 6 & Charge & 0.4 & 600 & 1185 & 13 & Discharge & -0.1 & 600 & 2580 \\
\hline 7 & Idle & $\circ$ & 30 & 1215 & 14 & Charge & 0.4 & 600 & 3180 \\
\hline
\end{tabular}

${ }^{2}$ The prediction for the voltage of the Yuasa and Multipower batteries is presented in Figures B.1 and B.2 respectively. 

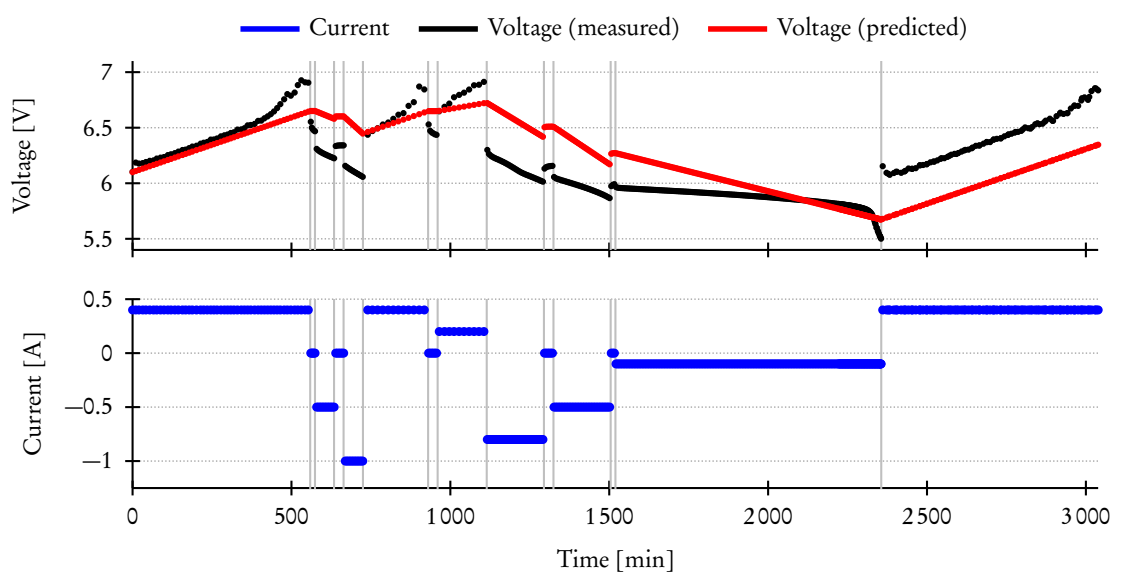

Figure 2.10: The applied current and resulting voltage during a the test on the Conrad battery. The vertical lines represent the moment of step change.

\subsection{SOC PREDICTIONS}

In this section the $\mathrm{DiBu}$-model is verified by demonstrating its predictive capabilities. Firstly the state of charge of three different lead acid batteries is predicted for different situations. Secondly the wider applicability of the DiBu-model is demonstrated by SoC predictions for Lithium-ion polymer and Lithium Ironphosphate batteries.

\subsubsection{Proof Of PRINCIPLE WITH Pb-ACID BatTeries}

The prediction for the state of charge for each of the three used $\mathrm{Pb}$-acid batteries ${ }^{3}$ is displayed in Figure 2.11. In this figure, the predicted SoC is compared to the SoC calculated directly from measurements on each of the three batteries, by means of the Coulomb counting method [53]. Furthermore the SoC predicted with the DiBu-model is also compared to the SoC predicted using the KiBaM model. The KiBaM model or Kinetic Battery Model is a well known and often used model for the prediction of the SoC of lead-acid batteries[46]. The values for the parameters of the $\mathrm{KiBaM}$ model used for the predictions are included in Table B.1. The differences between $\mathrm{SoC}^{\text {meas }}$ and $\mathrm{SoC}^{\mathrm{DiBu}}$ and $\mathrm{SoC} \mathrm{C}^{\mathrm{KiBam}}$, respectively, for al steps of the three tested batteries are included in Table B.2. Note, that the SoC differences included in the Tables B.2, B.3, B.5 and B.6 as well as those mentioned in the text are absolute differences between SoC's, expressed in percentage of the maximum SoC.

Figure 2.11a shows the measured and predicted SoC of the Conrad battery. At the start, the SoC predicted with the DiBu-model ( $\mathrm{SoC}^{\mathrm{DiBu}}$ ) deviates only slightly

\footnotetext{
${ }^{3}$ These are the same batteries that were used in Section 2.5.
} 
from the measured SoC (SoC $\left.{ }^{\text {meas }}\right)$ : from the start of the experiment to the end of Step $8(\mathrm{t} \sim 1100 \mathrm{~min})$, the maximum difference between the SoC ${ }^{\mathrm{DiBu}}$ and the SoCmeas is $2.6 \%$. During Step 9, however, the deviation between the SoC ${ }^{\mathrm{DiBu}}$ and the SoC ${ }^{\text {meas }}$ doubles to $5.1 \%$. From step Step 10 onward the deviation increases slowly, reaching a maximum of $12.1 \%$ at the end of Step 14. The SoC predicted using the KiBaM model ( $\mathrm{SoC}^{\mathrm{KiBaM}}$ ) starts out with a slight, increasing deviation. From the start of the experiment to Step 12 at $\mathrm{t} \sim 1400 \mathrm{~min}$, the SoC $\mathrm{K}^{\mathrm{iBaM}}$ is less accurate than the SoC ${ }^{\mathrm{DiBu}}$. From Step 12 onward however, SoC ${ }^{\mathrm{KiBaM}}$ is slightly more accurate than the SoC ${ }^{\mathrm{DiBu}}$.

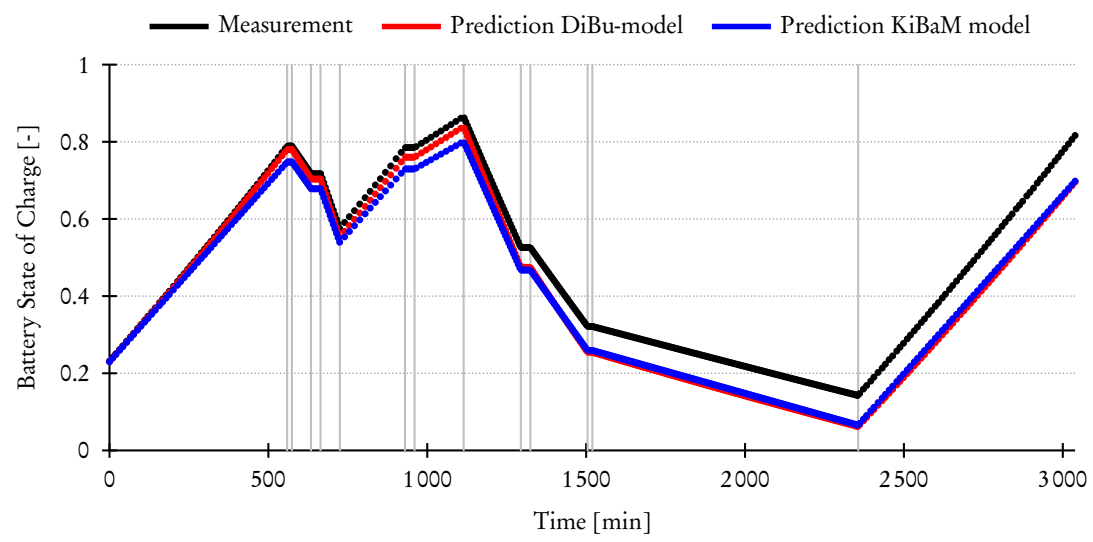

(a) SoC of the Conrad battery.

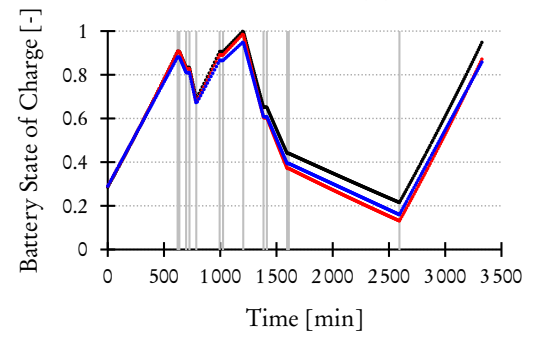

(b) SoC of the Yuasa battery.

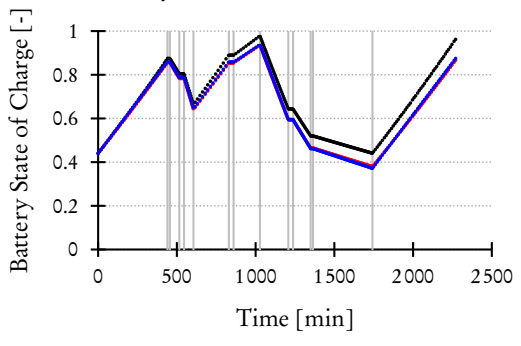

(c) SoC of the Multipower battery.

Figure 2.11: State of Charge of selected batteries (see Table 2.1), calculated from measurements on the batteries compared to predictions using the DiBu-model and the KiBaM model. The vertical lines represent the moment of step change.

The measured and predicted SoC of the Yuasa battery are shown in Figure 2.11b. From the start of the experiment to the end of Step $8(\mathrm{t} \sim 1250 \mathrm{~min})$, there is only a slight difference between the $\mathrm{SoC}^{\mathrm{DiBu}}$ and the $\mathrm{SoC}^{\text {meas }}$ : the maximum difference in this time interval is $1.5 \%$. The difference increases to $8.4 \%$ over the three discharge steps that follow. In the last charge step (Step 14), the difference between the SoC ${ }^{\mathrm{DiBu}}$ and the $\mathrm{SoC}^{\text {meas }}$ increases slightly, to $8.5 \%$ at the end of the 
experiment. From the start of the experiment, until the middle of Step $10(\mathrm{t} \sim$ $1400 \mathrm{~min})$, the SoC $\mathrm{KiBa}$ is less accurate than the $\mathrm{SoC}^{\mathrm{DiBu}}$. During the following discharge steps the SoC ${ }^{\mathrm{KiBaM}}$ is more accurate than the SoC ${ }^{\mathrm{DiBu}}$. During the final charging step (step 14) the SoC ${ }^{\mathrm{KiBaM}}$ again becomes less accurate than the $\mathrm{SoC}^{\mathrm{DiBu}}$. Moreover, over-all the $\mathrm{SoC}^{\mathrm{DiBu}}$ is more accurate than the $\mathrm{SoC}^{\mathrm{KiBaM}}$.

The SoC predicted for the Multipower battery compared to the measured SoC, as shown in Figure 2.11c, behave in much the same way as was the case for the Conrad and Yuasa batteries. However, where the differences between SoC ${ }^{\mathrm{DiBu}}$ and $\mathrm{SoC}^{\text {meas }}$ for the Conrad and Yuasa batteries strongly increase during Step 9, for the Multipower battery this is not the case. The difference between the $\mathrm{SoC}^{\mathrm{DiBu}}$ and the SoC ${ }^{\text {meas }}$ is small $(1.9 \%)$ at the start of the experiment, during the experiment it slowly increases to $9.7 \%$ at the end of the final step (Step 14). From the start of the experiment, the SoC ${ }^{\mathrm{KiBaM}}$ is slightly more accurate than the SoC ${ }^{\mathrm{DiBu}}$. During Steps $10-13$ the $\mathrm{SoC}^{\mathrm{DiBu}}$ is more accurate than the SoC ${ }^{\mathrm{KiBaM}}$, and in the final step Step 14 the SoC $\mathrm{KiBa}^{\mathrm{iBa}}$ is more accurate again. The SoC $\mathrm{C}^{\mathrm{DiBu}}$ and $\mathrm{SoC}{ }^{\mathrm{KiBaM}}$ are very similar in this case, the absolute difference between the two is never more than $0.9 \%$.

\section{Verification with an alternative scenario}

A second scenario has been explored where the Conrad battery is cyclically charged and discharged (referred to as Conrad-cycle). The battery is charged with $400 \mathrm{~mA}$ for 8 hours, and discharged with $-400 \mathrm{~mA}$ for 8 hours, between the charge and discharge steps the battery is idle for 30 minutes. The applied currents for each step in the scenario are given in Table 2.3. Figure 2.12 shows the measured and the predicted SoC using the DiBu-model and the KiBaM model during this scenario.

Table 2.3: The charge, discharge and idle steps used in the cyclic charging / discharging experiment or which the results are presented in Figure 2.12.

\begin{tabular}{clccc||ccccc}
\hline Step \# & Type & Current (A) & Length $(\min )$ & Total $(\mathrm{min})$ & Step \# & Type & Current (A) & Length (min) & Total(min) \\
\hline 1 & Charge & 4 & 480 & 480 & 7 & Discharge & -4 & 480 & 2010 \\
2 & Idle & 0 & 30 & 510 & 8 & Idle & $\circ$ & 30 & 2040 \\
3 & Discharge & -4 & 480 & 990 & 9 & Charge & 4 & 480 & 2520 \\
4 & Idle & 0 & 30 & 1020 & 10 & Idle & $\circ$ & 30 & 2550 \\
5 & Charge & 4 & 480 & 1500 & 11 & Discharge & -4 & 480 & 3030 \\
6 & Idle & 0 & 30 & 1530 & & & & & \\
\hline
\end{tabular}

In the first cycle the SoC ${ }^{\mathrm{DiBu}}$ matches the SOC ${ }^{\text {meas }}$ closely, the largest deviation in this cycle is $3.2 \%$, which occurs at the end of Step 3, the discharge step. During the second cycle the difference between $\mathrm{SOC}^{\text {meas }}$ and $\mathrm{SoC}^{\mathrm{DiBu}}$ remains mostly constant during Step 4, 5, 6 and then doubles to $6.4 \%$ at the end of the discharge step, Step 7. The third cycle shows again an increase (to $9.7 \%$ ) in the deviation between SOC ${ }^{\text {meas }}$ and SoC ${ }^{\mathrm{DiBu}}$ in the discharge step (Step 11). So the deviation between $\mathrm{SOC}^{\text {meas }}$ and $\mathrm{SoC} \mathrm{C}^{\mathrm{DiBu}}$ is progressively worse in consecutive cycles, and in this scenario the deviation increases mainly during the discharge steps. The SoC ${ }^{\mathrm{KiBaM}}$ already shows a $3.3 \%$ deviation from the $\mathrm{SoC}^{\text {meas }}$ after the first step. 


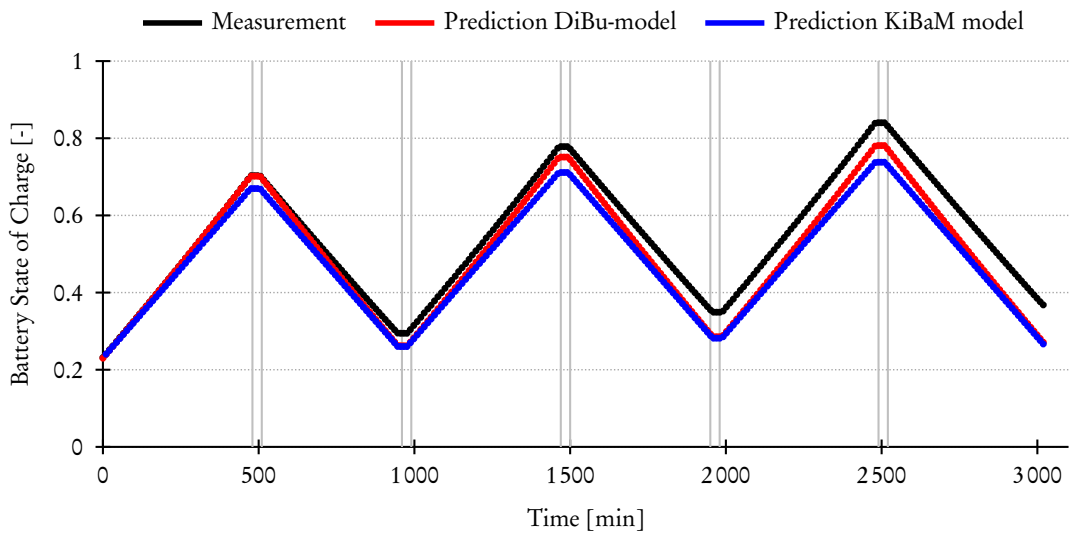

Figure 2.12: State of Charge of the Conrad battery, during cyclic charging / discharging, calculated from measurements compared to predictions using the DiBu-model and the KiBaM model. The vertical lines represent the moment of step change.

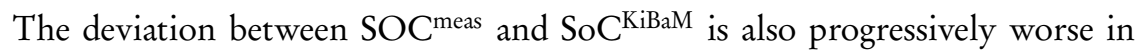
consecutive cycles but the deviation increases during the charge steps (Step 1, 5, 9, and remains constant during the other steps. In this scenario the SoC predicted using the DiBu-model is always more accurate than the SoC predicted using the $\mathrm{KiBaM}$ model. The deviations between the $\mathrm{SOC}^{\text {meas }}$ and $\mathrm{SoC}^{\mathrm{DiBu}}$ or SoC $\mathrm{KiBaM}^{\mathrm{B}}$ for each step have been included in Table B. 3 in the appendix.

\section{Influence of parameters $\alpha, \beta, \gamma$ and $\delta$ on the prediction}

To test the Influence of parameters $\alpha, \beta, \gamma$ and $\delta$ on the prediction, additional predictions were done for the scenario described in Table 2.2, with altered parameters. For these predictions one of the parameters, $\alpha, \beta, \gamma$ and $\delta$ was given a value $10 \%$ larger or smaller than previously determined, i.e. the value for each of the parameters (as given in Table 2.1) $\pm 10 \%$. For each of these scenarios the largest deviation and the over-all deviation between $\mathrm{SOC}^{\text {meas }}$ and $\mathrm{SoC}^{\mathrm{DiBu}}$ is presented in Table B.4 in the appendix.

In general changing the value of one of the parameters $\alpha, \beta, \gamma$ and $\delta \pm 10 \%$ does not have a large influence of resulting prediction. In general both the maximum deviation and the over-all deviation between $\mathrm{SOC}^{\text {meas }}$ and $\mathrm{SoC}^{\mathrm{DiBu}}$ increases or decreases sim $0.5 \%$ when one of the parameters is changed. Changing the parameter $\beta$ or $\gamma$ has the least effect on the prediction, in some cases no effect at all is observed. However, as these parameters are used when the battery is in an idle step after discharging, and the battery spends more time (dis)charging than idling, it is expected that these parameters have less influence on the prediction. If all four parameters are changed $\pm 10 \%$ significant changes in the resulting 
prediction are observed. In general, either the maximum deviation or the over-all deviation between $\mathrm{SOC}^{\text {meas }}$ and $\mathrm{SoC}^{\mathrm{DiBu}}$ significantly increases. In none of the scenarios, a changed parameter results in a decrease of both the maximum and over-all deviations between $\mathrm{SOC}^{\text {meas }}$ and $\mathrm{SoC}^{\mathrm{DiBu}}$. Note that, it is clear that a decrease in the maximum deviation while the over-all deviation increases results in a poorer prediction. However, an increase in the maximum deviation while the over-all deviation could be a positive development at first glance, but if a decision is taken based on a badly predicted step in an over-all accurate prediction there could still be negative consequences.

In summary, if the value of one of the parameters $\alpha, \beta, \gamma$ or $\delta$ is determined poorly, and is $\pm 10 \%$ larger or smaller than it actually should be, there is only a small impact on the resulting prediction, however if all parameters are off by \pm $10 \%$ the influence on the resulting prediction will be significant.

\section{In conclusion}

From the experiments using the Conrad, Yuasa and Multipower batteries, outlined in Tables 2.2 and 2.3 and shown in Figures 2.10, 2.11 and 2.12 it can be concluded that:

- The accuracy of the SoC $C^{\mathrm{DiBu}}$ is very good in the first 1000 minutes of both experiments, having a maximum difference to $S_{0} C^{\text {meas }}$ of only 2.5 $\%$ in the first experiment, and $3.2 \%$ in the second.

- The accuracy of the SoC ${ }^{\mathrm{DiBu}}$ deteriorates after 1000 minutes, leading to a maximum difference between the $\mathrm{SoC}^{\mathrm{DiBu}}$ and the $\mathrm{SoC}^{\text {meas }}$ of $12.1 \%$ in both experiments.

- The SoC $C^{\mathrm{DiBu}}$ prediction for discharge steps is less accurate than for charge steps.

- The level of accuracy of the SoC ${ }^{\mathrm{DiBu}}$ is comparable to the level of accuracy of the $\mathrm{SoC}^{\mathrm{KiBaM}}$. Generally, in charging steps the SoC ${ }^{\mathrm{DiBu}}$ is more accurate than the SoC ${ }^{\mathrm{KiBaM}}$, while the reverse is true in the discharging steps.

\subsubsection{IMPROVEMENTS TO THE SOC PREDICTION}

The state of charge at time $t$ is predicted using the measured values for the voltage and current at a time $t^{\prime}<t$. In each consecutive step of the state of charge prediction, the values predicted for the previous time step are used as input for the next step. Although the SoC prediction of one single time step (e.g $\Delta t=30$ seconds) produces only a very small error, the SoC predicted over a longer period of time requires many consecutive predictions and in each of the consecutive predictions the error accumulates, so the total error may increase and become considerable. In the previous experiments the state of charge was predicted over long periods up to 3400 minutes (i.e. 57 hours, leading to 6800 steps of 30 seconds) in advance. In the experiments the $\mathrm{SoC}^{\mathrm{DiBu}}$ deviated at most $2.5 \%$ from 
the SoC $\mathrm{C}^{\text {meas }}$ in the first 1000 minutes, after which the accuracy of the SoC ${ }^{\mathrm{DiBu}}$ started deteriorating. This implies that, in this experiment the accuracy of the state of charge prediction using the DiBu-model is only of a high quality when the prediction horizon is not too long. Based on these insights, in a practical setting, the starting values for the battery voltage $\left(\mathrm{U}_{t}\right)$ and state of charge $\left(\mathrm{SoC}_{t}\right)$ should be calibrated after some period of time based on measurements or other indications for the values of $\left(\mathrm{U}_{t}\right)$ and $\left(\mathrm{SoC}_{t}\right)$ achieved at the time of calibration. These standard techniques should improve the accuracy of the prediction for the next time interval. It was also observed that the inaccuracy of the SoC ${ }^{\mathrm{DiBu}}$ increased during the discharging steps, in particular when a high discharging current was applied. Therefore, it is suggested that for improving the accuracy in a practical setting, the starting values for the battery voltage $\left(\mathrm{U}_{t}\right)$ and state of charge $\left(\mathrm{SoC}_{t}\right)$ should be updated after each discharging step. Using these improvements the maximum prediction horizon is limited to the time of one full charge / discharge cycle. Moreover, the inaccuracy caused by a discharge step is corrected immediately after this step, so the overall accuracy should improve.

Note that if the DiBu-model is used within a (smart) grid simulation, updating the starting values for $\left(\mathrm{U}_{t}\right)$ and $\left(\mathrm{SoC}_{t}\right)$ effectively shortens the maximum time over which the SoC ${ }^{\mathrm{DiBu}}$ can be predicted accurately. However, if the DiBumodel is used to predict the behaviour of an actual battery, for example when using model-predictive control, measurements on that battery can be used to update the starting values for $\left(\mathrm{U}_{t}\right)$ and $\left(\mathrm{SoC}_{t}\right)$. In practice, battery management hardware (e.g. the Victron Multiplus [68]) is almost always involved when a battery is used in a (smart) grid environment. It is common for such a device to measure the battery voltage and current, and determine the actual SoC from these measurements. It is also common for these devices to recalibrate the SoC determination when the battery is either completely full or completely empty. The measured voltage, and / or determined SoC can be used freely to update the $\left(\mathrm{U}_{t}\right)$ and state of charge $\left(\mathrm{SoC}_{t}\right)$ to increase the accuracy of the prediction.

Based on the achieved results up to now a scenario for possible improvements has been explored: the starting values for $\left(\mathrm{U}_{t}\right)$ and $\left(\mathrm{SoC}_{t}\right)$ are calibrated at the beginning of a step that starts after a discharge step, i.e. at the beginning of Steps 4, 6, 10, 12 and 14 from Table 2.2. The results of these experiments are shown in Figure 2.13. The deviations between the $\mathrm{SoC}^{\mathrm{DiBu}}$ predicted without improvements, and the SoC ${ }^{\mathrm{DiBu}}$ predicted using the improvements for all steps of the three tested batteries are included in Table B.5.

Figure 2.13a displays the SoC ${ }^{\text {meas }}$ and $\mathrm{SoC}^{\mathrm{DiBu}}$ for the Conrad battery with and without the suggested improvements. If the improvements are applied, the difference between SoCmeas and $\mathrm{SoC}^{\mathrm{DiBu}}$ at the end of the experiment is reduced to $0.5 \%$. This is a significant improvement to the original experiment, but can be attributed mainly to the fact that the update occurred just before the start of the last step (Step 14). However, the maximum difference between SoC ${ }^{\text {meas }}$ and SoC ${ }^{\mathrm{DiBu}}$ during the whole experiment is reduced to $2.8 \%$, which occurs at the 


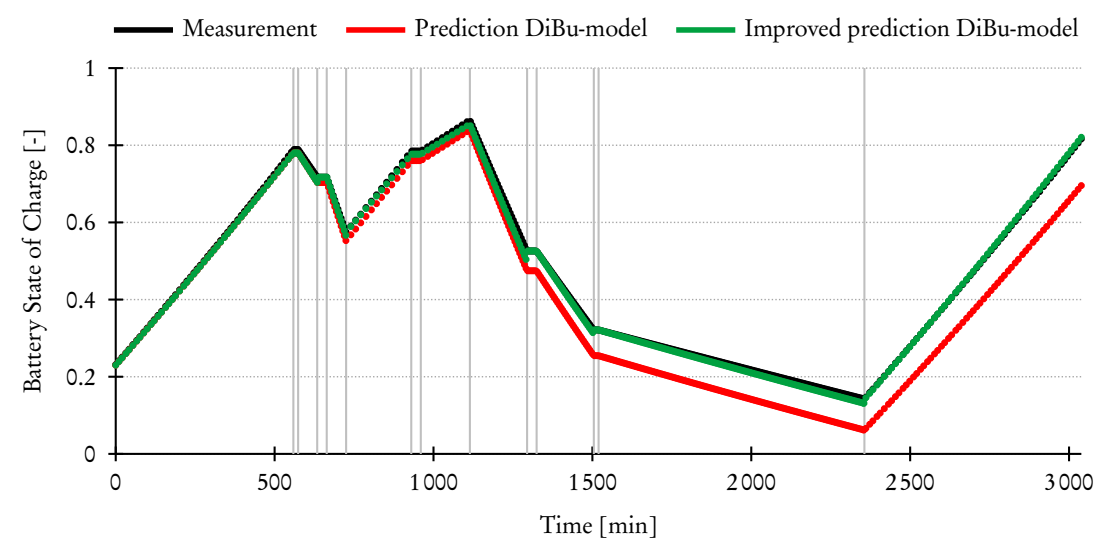

(a) SoC of the Conrad battery.

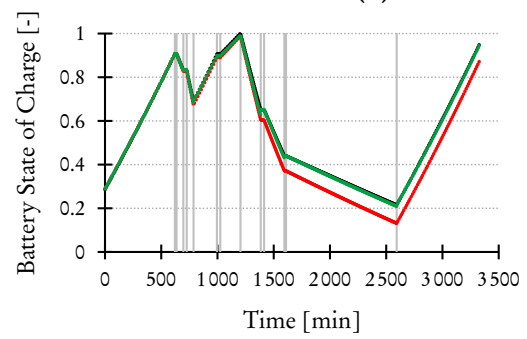

(b) SoC of the Yuasa battery.

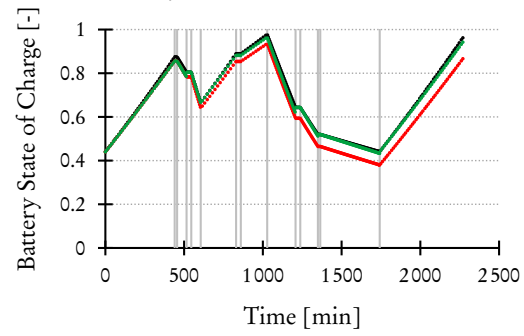

(c) SoC of the Multipower battery.

Figure 2.13: Comparison of the measured SoC and SoC predicted using the DiBu-model for the three batteries, updating the $\mathrm{SoC}_{\text {start }}$ and $\mathrm{V}_{\text {start }}$ at the end of each discharge step, or updating the SoC $\mathrm{C}_{\text {start }}$ and $\mathrm{V}_{\text {start }}$ at the ending of a step, after some specific time intervals. Note that in some intervals the green lines (representing the improvements) completely overlap the black line (representing the measurement) making these lines difficult to distinguish from each other. The vertical lines represent the moment of step change.

end of Step 9, and the average difference is $0.7 \%$. The difference between SoC ${ }^{\text {meas }}$ and SoC ${ }^{\mathrm{DiBu}}$ for the Yuasa battery, (see Figure 2.13 b) at the end of the experiment is $0.5 \%$, which is, again, a significant improvement to the original experiment, but again is caused by the update at the beginning of Step 14. The difference is small over the entire course of the experiment, staying below $1.3 \%$ except for the last part of step Step 9 where the difference increases to $2.7 \%$ within 30 minutes. When the improvements are applied on the SoC predictions for the Multipower battery, (see Figure 2.13c) similar improvements are observed. The difference between SoC ${ }^{\text {meas }}$ and $\mathrm{SoC}^{\mathrm{DiBu}}$ at the end of the experiment is reduced to $2.1 \%$. The maximum difference between the $\mathrm{SoC}^{\text {meas }}$ and $\mathrm{SoC}^{\mathrm{DiBu}}$ is reduced from $9.7 \%$ to $2.6 \%$ over all, where the maximum difference occurs during the 
last 30 minutes of Step 9. Note that improvements also could be applied to the predictions done with the KiBaM model. It is to be expected that the accuracy

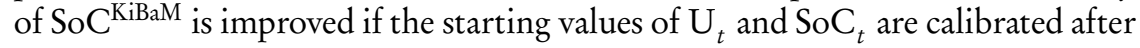
each discharge step. However, this has not been explored further in this work.

From the improved experiments on the Conrad, Yuasa and Multipower batteries, shown in Figure 2.13, it can be concluded that:

- The accuracy of the State of Charge predicted using the DiBu-model can be improved when the time over which the prediction is made is shortened, i.e. if the starting values of $\mathrm{U}_{t}$ and $\mathrm{SoC}_{t}$ are calibrated after a certain amount of time.

- The accuracy of the State of Charge predicted using the DiBu-model can be improved when the values for $\mathrm{U}_{t}$ and $\mathrm{SoC}_{t}$ are calibrated after each discharge step.

\subsubsection{VERIFICATION WITH ADDITIONAL BATTERY TYPES}

To demonstrate the wider applicability of the DiBu-model, the model is also applied on Lithium-ion Polymer ( $\mathrm{Li}$-Poly) and Lithium Iron-phosphate $(\mathrm{LiFePo})^{4}$ batteries. The parameters of these batteries, listed in Table 2.4, were determined using the method outlined in Section 2.4. It was determined from the measurements that even though the capacity recovery effect is present in both Li-Poly and LiFePo batteries, its effects for the DiBu-model are minimal (see Figure 2.14). Note, that the voltage where the second discharge starts is almost identical to the voltage where the first discharge ends, even after an idle step of one hour. For the model this means that the voltage remains constant during idle steps after discharging, hence the parameters $\beta$ and $\gamma$ are both chosen to be zero.

Table 2.4: Characteristics and parameters determined for the Li-Poly and LiFePo test batteries.

\begin{tabular}{lcc}
\hline & Li-Poly & LiFePo \\
\hline Rated capacity (Ah) & 5.2 & 4.5 \\
Nominal voltage (V) & 25.2 & 26.4 \\
$\alpha(\mathrm{V} / \mathrm{A})$ & $2.834 \times 10^{-4}$ & $1.765 \times 10^{-4}$ \\
$\beta(-)$ & 0 & 0 \\
$\gamma(\mathrm{min})$ & $\circ$ & $\circ$ \\
$\delta(\mathrm{A} / \mathrm{V})$ & $2.772 \times 10^{4}$ & $5.169 \times 10^{4}$ \\
\hline
\end{tabular}

Note, that in previous (sub)sections the SoC predictions using the DiBu-model were compared to predictions made using the $\mathrm{KiBaM}$ model. However, as the $\mathrm{KiBaM}$ model is only applicable for lead-acid batteries, it could not be used here. Unfortunately, due to the complexity of the models available for the

\footnotetext{
${ }^{4}$ Although LiFePo is used in this work as the abbreviation for Lithium Iron-phosphate, its proper chemical formula is $\mathrm{LiFePO}$
} 
SoC prediction of Li-Poly and LiFePo batteries, no suitable equivalent model was available for comparison to the results of the DiBu-model for these battery types.

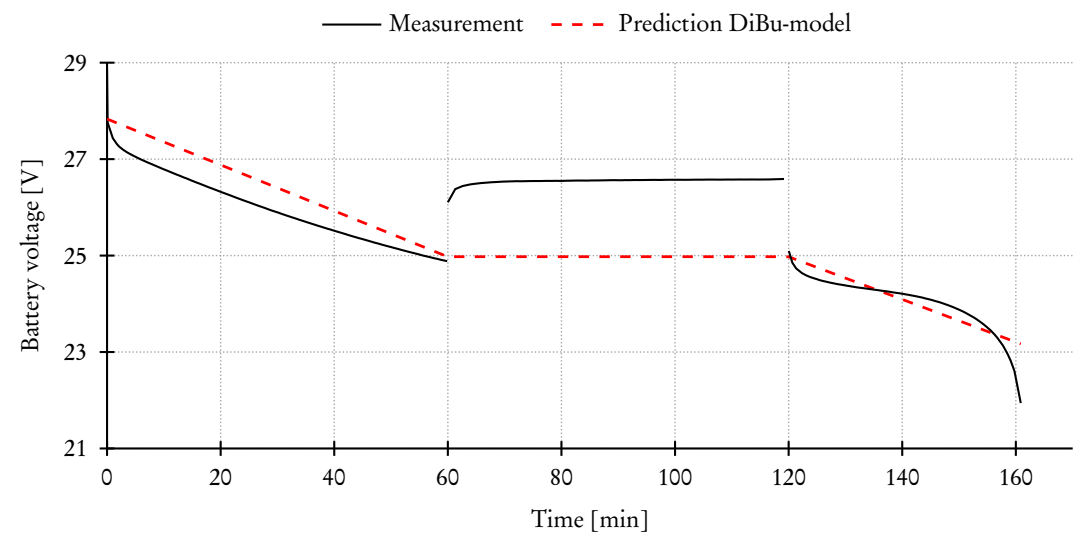

Figure 2.14: Example of the determination of parameters $\beta$ and $\gamma$ for the LiPoly testing battery. The voltage at the end of the first discharge step $(t=60$ $\mathrm{min}$ ) is almost equal to the voltage at the beginning of the second discharge step $(\mathrm{t}=120 \mathrm{~min})$, hence $\beta$ and $\gamma$ are chosen such that the starting voltage of the second discharge step is predicted correctly, an the voltage behaviour during the idle step is ignored.

\section{Lithium-ion Polymer batteries}

The behaviour of the Li-Poly battery was investigated for a typical scenario, during a set of consecutive charge, discharge and idle steps. However, due to limitations of the battery and testing equipment it was not possible to apply the same test as for the $\mathrm{Pb}$-acid batteries. The characteristics of the different steps, used for the Li-Poly battery are outlined in Table 2.5.

Table 2.5: The charge, discharge and idle steps used in the experiment for which the results are given in Figure 2.15

\begin{tabular}{clccc||ccccc}
\hline Step \# & Type & Current (A) & Length (min) & Total $(\mathrm{min})$ & Step \# & Type & Current (A) & Length (min) & Total(min) \\
\hline 1 & Idle & $\circ$ & 5 & 5 & 12 & Discharge & -2.6 & 15 & 340 \\
2 & Charge & 2 & 45 & 50 & 13 & Idle & 0 & 30 & 370 \\
3 & Charge & 1.5 & 45 & 95 & 14 & Charge & 1.3 & 30 & 400 \\
4 & Idle & 0 & 15 & 110 & 15 & Charge & $2.2 \rightarrow 1.2$ & 15 & 415 \\
5 & Discharge & -1.3 & 30 & 140 & 16 & Discharge & -5.2 & 15 & 430 \\
6 & Idle & 0 & 30 & 170 & 17 & Idle & 0 & 30 & 460 \\
7 & Discharge & -1.3 & 30 & 200 & 18 & Charge & 2 & 18.5 & 478.5 \\
8 & Charge & 1.5 & 60 & 260 & 19 & Charge & $2.0 \rightarrow 0.65$ & 41.5 & 520 \\
9 & Charge & 2 & 25 & 285 & 20 & Idle & 0 & 10 & 530 \\
10 & Charge & $2.0 \rightarrow 1.0$ & 20 & 305 & 21 & Discharge & -2.6 & 25 & 555 \\
11 & Discharge & -1.3 & 20 & 325 & 22 & Charge & 1.3 & & 25 \\
\hline
\end{tabular}


In Figure 2.15 the SoC calculated from measurements ${ }^{5}$, and the predicted SoC for the Li-Poly battery are displayed. The pattern of SoC ${ }^{\text {DiBu }}$ follows closely the pattern of $\mathrm{SoC}^{\text {meas }}$ but the difference increases over time. The largest difference between SoC ${ }^{\mathrm{DiBu}}$ and $\mathrm{SoC}^{\text {meas }}$ is $4.3 \%$, reached at the start of Step 16. In Steps 1 through 15 the maximum difference between $\mathrm{SoC}^{\mathrm{DiBu}}$ and SoC $\mathrm{C}^{\text {meas }}$ is $2.1 \%$, which is reached at the end of Step 10. After Step 17 the difference between SoC ${ }^{\text {DiBu }}$ and $\mathrm{SoC}^{\text {meas }}$ increases in the discharge steps and decreases somewhat in the charge steps. The difference between the $\mathrm{SoC}^{\mathrm{DiBu}}$ and $\mathrm{SoC}^{\text {meas }}$ for all steps has been included in Table B.6.

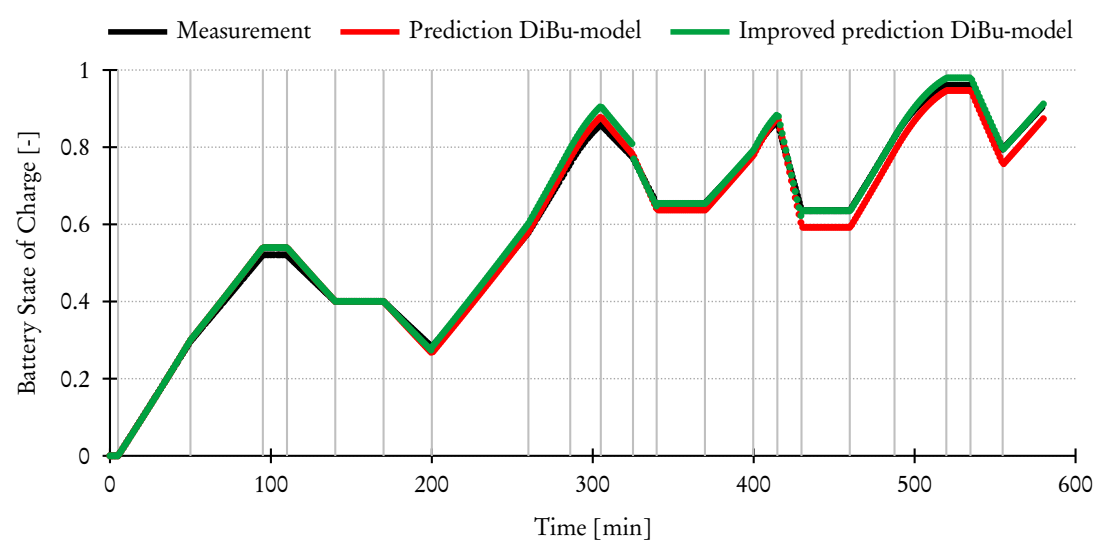

Figure 2.15: State of Charge of the Li-Poly battery (see Table 2.4), calculated from measurements on the batteries, compared to predictions using the $\mathrm{DiBu}-$ model, and compared to predictions using the $\mathrm{DiBu}$-model updating the $\mathrm{SoC}_{\text {start }}$ and $\mathrm{V}_{\text {start }}$ at the end of each discharge step. The vertical lines represent the moment of step change.

As mentioned the increase in difference between $\mathrm{SoC}^{\mathrm{DiBu}}$ and $\mathrm{SoC}^{\text {meas }}$ is largest in the discharge steps. At the end of (discharge) Steps 12, 16 and 21 the difference is $1.7 \%, 4.3 \%$ and $3.9 \%$ respectively. At the end of charge steps that follow these discharge steps, namely Steps 15, 19 and 22, the difference is $0.9 \%, 1.3$ $\%$ and $3.3 \%$, which is a reduction in all cases. This behaviour matches the behaviour observed for the lead-acid batteries (Section 2.6.1). The SoC ${ }^{\mathrm{DiBu}}$ can be improved if the values for $\mathrm{U}_{t}$ and $\mathrm{SoC}_{t}$ are calibrated after each discharge step, as proposed in Section 2.6.2. The green line in Figure 2.15 shows the SoC ${ }^{D i B u}$ if these improvements are applied. In this case the aforementioned differences in Steps 12, 16 and 21 are greatly reduced. However, the largest difference (4.8 $\%$ ) is now located in Step 10 and is larger than the largest difference without the improvements applied. This is caused by an overestimation of the SoC in that step. On the whole, however, the difference between $\mathrm{SoC}^{\mathrm{DiBu}}$ and $\mathrm{SoC}^{\text {meas }}$ is

\footnotetext{
5The voltage and current measurements have been included in Figure B.4
} 
smaller when the improvements are applied. The difference between the SoC ${ }^{\mathrm{DiBu}}$, with and without the improvements, for all steps is presented in Table B.6.

\section{Lithium Iron-phosphate batteries}

The behaviour of the LiFePo batteries (see Table 2.4) was also investigated for a typical scenario, during a set of consecutive charge, discharge and idle steps. The characteristics of the different steps, are outlined in Table 2.6. Note, that again the scenario is not the same as the test scenario for the Pb-acid and $\mathrm{Li}$ Poly batteries, this is again the result of limitations to the battery and testing equipment.

Table 2.6: The charge, discharge and idle steps used in the experiment for which the results are given in in Figure 2.16

\begin{tabular}{|c|c|c|c|c|c|c|c|c|c|}
\hline Step \# & Type & Current (A) & Length (min) & Total (min) & Step \# & Type & Current (A) & Length (min) & Total(min) \\
\hline 1 & Charge & 2 & 45 & 45 & 13 & Discharge & -4 & 15 & 605 \\
\hline 2 & Charge & 0.5 & 245 & 290 & 14 & Idle & $\circ$ & 30 & 635 \\
\hline 3 & Idle & $\circ$ & 15 & 305 & 15 & Charge & 0.5 & 120 & 755 \\
\hline 4 & Discharge & -1 & 30 & 335 & 16 & Charge & 1 & 60 & 815 \\
\hline 5 & Discharge & -1.5 & 30 & 365 & 17 & Charge & 2 & 30 & 845 \\
\hline 6 & Discharge & -2 & 30 & 395 & 18 & Idle & $\circ$ & 30 & 875 \\
\hline 7 & Charge & 1.5 & 60 & 455 & 19 & Discharge & -0.5 & 120 & 995 \\
\hline 8 & Charge & 2 & 45 & 500 & 20 & Discharge & -1 & 60 & 1055 \\
\hline 9 & Idle & $\circ$ & 15 & 515 & 21 & Charge & $\circ$ & 15 & 1070 \\
\hline 10 & Discharge & -1 & 30 & 545 & 22 & Discharge & -2 & 20 & 1090 \\
\hline 11 & Discharge & -2 & 25 & 570 & 23 & Charge & 1 & 120 & 1210 \\
\hline 12 & Discharge & -3 & 20 & 590 & & & & & \\
\hline
\end{tabular}

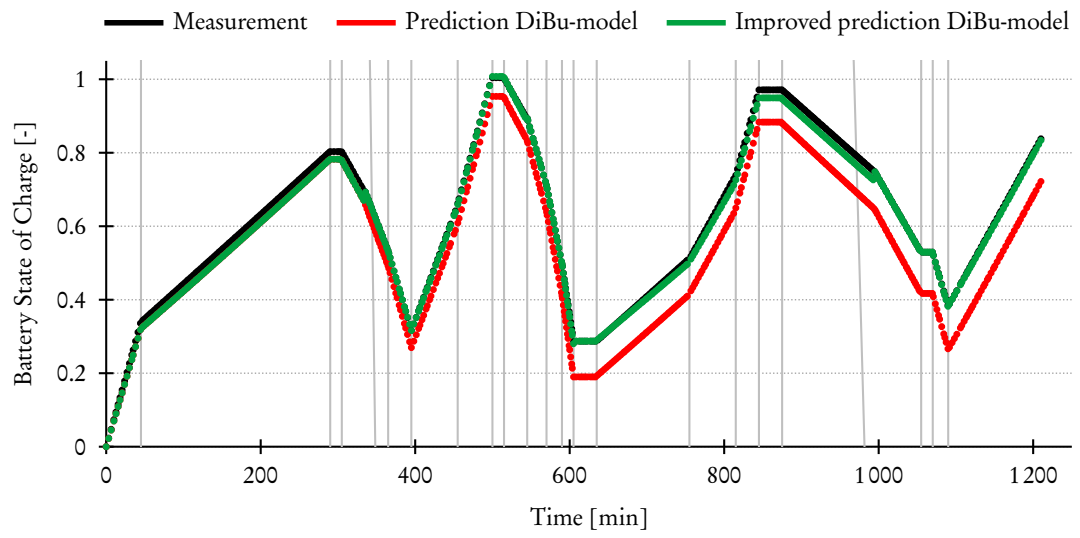

Figure 2.16: State of Charge of the LiFePo battery (see Table 2.4), calculated from measurements on the batteries compared to predictions using the $\mathrm{DiBu}-$ model, and compared to predictions using the DiBu-model updating the $\mathrm{SoC}_{\text {start }}$ and $\mathrm{V}_{\text {start }}$ at the end of each discharge step. The vertical lines represent the moment of step change. 
In Figure 2.16 the state of charge derived from measurements ${ }^{6}$ on the LiFePo battery $\left(\mathrm{SoC}^{\text {meas }}\right)$ and the predicted state of charge $\left(\mathrm{SoC}^{\mathrm{DiBu}}\right)$ are shown. The difference between the SoC ${ }^{\text {meas }}$ and the SoC ${ }^{\text {DiBu }}$ increases progressively during the measurement, except during Step 16, where the difference deceases slightly. The largest difference between $\left(\mathrm{SoC}^{\text {meas }}\right)$ and $\left(\mathrm{SoC}^{\mathrm{DiBu}}\right)$ is $11.6 \%$ and this indeed occurs at the end of the last step (Step 23). The difference increases most during the discharge steps, and remains mostly constant during the charge and idle steps (for the difference per step see table B.6). If the improvements proposed in Section 2.6.2 are applied (the values for $\mathrm{U}_{t}$ and $\mathrm{SoC}_{t}$ are re-calibrated after Steps 4,5,6,10,11,12,13,19,20 and 22), the predictions improve. The corresponding SoC ${ }^{\mathrm{DiBu}}$ is also shown in Figure 2.16. When the improvements are applied, the largest difference between $\left(\mathrm{SoC}^{\text {meas }}\right)$ and $\left(\mathrm{SoC}^{\mathrm{DiBu}}\right)$ is then $2.7 \%$, and this occurs at the end of Step 4 . The average difference is $1.2 \%$.

From the experiments on the Li-Poly and LiFePo batteries, outlined in Tables 2.4 and 2.5 and shown in Figures 2.15 and 2.16 it can be concluded that:

- The capacity recovery effect is negligible for Li-Poly and LiFePo batteries, hence the parameters $\beta$ and $\gamma$ can both be chosen to be zero.

- The DiBu model can be successfully used to predict the SoC of the tested Li-Poly and LiFePo batteries.

- For the Li-Poly battery the difference between SoC ${ }^{\mathrm{DiBu}}$ and $\mathrm{SoC}^{\text {meas }}$ fluctuates over the various charge, discharge and idle steps. The difference remains quite small, the largest difference is $3.9 \%$, at the end of step 16 while the average difference is $1.7 \%$.

- For the LiFePo battery the difference between SoC ${ }^{\mathrm{DiBu}}$ and SoC ${ }^{\text {meas }}$ progressively increases, reaching a difference between between $\mathrm{SoC}^{\mathrm{DiBu}}$ and SoC ${ }^{\text {meas }}$ of $11.8 \%$ at the end of the experiment, while the average difference is $7 \%$.

- For both battery types the difference between SoC ${ }^{\text {DiBu }}$ and SoC ${ }^{\text {meas }}$ increases most during the discharge steps.

- For both battery types the accuracy of the State of Charge prediction using the DiBu-model can be improved if the values for $\mathrm{U}_{t}$ and $\mathrm{SoC}_{t}$ are calibrated after each discharge step. The average difference is reduced to $1.5 \%$ for the Li-Poly battery and to $1.7 \%$ for the LiFePo battery.

\subsection{CONCLUSIONS}

In this chapter the DiBu-model, a simple yet accurate model for the prediction of the battery state of charge, is discussed. This model was developed specifically for usage in simulation tools and for prediction and control within smart grid

\footnotetext{
${ }^{6}$ The voltage and current measurements have been included in Figure B.5
} 
applications. As such the model yields accurate predictions of the state of charge, while being simple enough to be applied in such tools.

As a means of verification, the DiBu-model has been applied to predict the state of charge of several different batteries. The model predicts the battery voltage during charging, discharging and idle periods, and based on these voltages the state of charge is predicted. To apply the model, first four parameters have to be determined from measurements on the battery in question.

In a first step it has been shown that the DiBu-model can be used to accurately predict the behaviour of various lead-acid batteries. The difference between the state of charge predicted using the DiBu-model $\left(\mathrm{SoC}^{\mathrm{DiBu}}\right)$, and the state of charge calculated from the measurements $\left(\mathrm{SoC}^{\text {meas }}\right)$ for all predictions has been summarised in Table 2.7.

Table 2.7: Average and maximum deviation between $\mathrm{SoC}^{\text {meas }}$ and $\mathrm{SoC}^{\mathrm{DiBu}}$ off all experiments presented in Section 2.6.

\begin{tabular}{|c|c|c|c|c|c|}
\hline \multirow[t]{2}{*}{ SoC prediction } & \multicolumn{2}{|c|}{ Corresponding } & \multirow{2}{*}{$\begin{array}{c}\text { Average } \\
\text { deviation (\%) }\end{array}$} & \multirow{2}{*}{$\begin{array}{c}\text { Maximum } \\
\text { deviation (\%) }\end{array}$} & \multirow{2}{*}{$\begin{array}{c}\text { Occurs in } \\
\text { step \# }\end{array}$} \\
\hline & Figure & Table & & & \\
\hline Conrad & $2.11 \mathrm{a}$ & 2.2 & $5 \cdot 7$ & 12.1 & 14 \\
\hline Conrad - improvements & $2.11 \mathrm{a}$ & 2.2 & 0.7 & 2.8 & 9 \\
\hline Yuasa & $2.11 \mathrm{~b}$ & 2.2 & 5.6 & 8.5 & 14 \\
\hline Yuasa - improvements & $2.11 b$ & 2.2 & 0.5 & 2.7 & 9 \\
\hline Multipower & $2.11 \mathrm{c}$ & 2.2 & 4.6 & $9 \cdot 7$ & 14 \\
\hline Multipower - improvements & $2.11 \mathrm{c}$ & 2.2 & 0.8 & 2.6 & 9 \\
\hline Conrad - cycle & 2.12 & 2.3 & 4.0 & $9 \cdot 7$ & 11 \\
\hline Li-Poly & 2.15 & 2.5 & 1.7 & $3 \cdot 9$ & 22 \\
\hline Li-Poly - improvements & 2.15 & 2.5 & 1.5 & 4.8 & 10 \\
\hline $\mathrm{LiFePo}$ & 2.16 & 2.6 & 7.0 & 11.8 & 22 \\
\hline LiFePo - improvements & 2.16 & 2.6 & 1.2 & 2.7 & 4 \\
\hline
\end{tabular}

For $\mathrm{Pb}$-acid batteries, the difference between $\mathrm{SoC}^{\mathrm{DiBu}}$ and $\mathrm{SoC}^{\text {meas }}$ has been shown to be less than $10 \%$ for a state of charge prediction over 3000 minutes ( $\sim 50$ hours). It has also been shown that the accuracy of the state of charge predictions using the DiBu-model, is equal to, or in some cases better than the accuracy of state of charge predictions using the well established KiBaM model. However, because the $\mathrm{KiBaM}$ model is more complicated, and because (micro)grid simulations require simple yet accurate models, the KiBaM model is less suited for usage in tools for simulation, prediction and control of smart grids. Furthermore it has been shown that the DiBu-model also can be used to accurately predict the behaviour of Li-Poly and LiFePo batteries. In the case of the Li-Poly batteries the difference between $\mathrm{SoC}^{\mathrm{DiBu}}$ and $\mathrm{SoC}^{\text {meas }}$ has been shown to be $4.3 \%$ for a state of charge prediction over 600 minutes ( $\sim 10$ hours). In case of the LiFePo batteries the difference between $\mathrm{SoC}^{\mathrm{DiBu}}$ and $\mathrm{SoC}^{\text {meas }}$ has been shown to be $11.6 \%$ for a state of charge prediction over 1200 minutes ( 20 hours). It has also been shown that the accuracy of the predictions can be improved by periodically updating the starting values for the battery voltage and state of charge. 


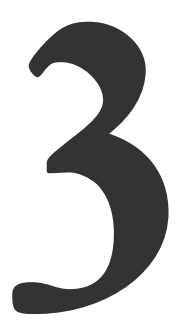

\title{
IMPLEMENTATION OF THE DiBU-MODEL
}

\begin{abstract}
In this chapter the implementation of the DiBu-model for battery state of charge prediction in DEMKit, a smart grid energy management toolkit, is presented. The implementation is discussed in detail and the differences between an ideal battery model previously used, and the new realistic model are shown. Moreover, the model and implementation are validated by comparing the State of Charge predicted using DEMKit to the State of Charge derived from measurements on an actual battery. The difference between the predicted and measured state of charge is generally less than 1.5\%, implying that the predicted battery behaviour matches reality quite well.
\end{abstract}

Parts of this chapter have been previously published in [H:s]. 


\section{$3.1 \quad$ INTRODUCTION}

Simulations of (smart) energy systems are used, for example, to predict and investigate the behaviour of energy systems that have yet to be built [69], or to find weaknesses in existing energy systems. Energy system simulation frameworks, such as TRIANA [70], GridSpice [60], and DEMKit [20] use models of the relevant devices, controllers and cables in a (smart) energy system to perform these simulations, with and without smart control. The accuracy of (the results of) a simulation depends on the accuracy of the models that are used in the simulation.

Batteries are an important part of smart energy systems. They are used, for instance, as a backup power source, the main power source for an electric car, or to (temporarily) store energy generated by e.g. PV-panels or wind turbines. Hence to accurately simulate a smart energy system, accurate models for batteries, e.g. the KiBaM model [46], the Schiffer Model [45] or the Dualfoil model [49] can be considered as valid options. The current DEMKit environment, however, does not use these accurate models but makes use of a very ideal battery model, e.g. the actual physical behaviour and tolerances of batteries are not considered. In the simulations, performed using the DEMKit environment, hundreds or even thousands of households are considered. If an accurate but complex battery model, like one of the aforementioned models, is used in these simulations the computation power needed would be very large, and the computation time would be extremely long. Hence, a simple yet accurate model for the prediction of the battery State of Charge (SoC) is needed. Note, that the DiBu-model for battery State of Charge prediction (Chapter 2) has been developed to predict a more realistic behaviour of a battery in simulation tools, while being simple. Therefore, in this Chapter ${ }^{1}$, this model is integrated and implemented using the optimization and simulation tool DEMKit and is combined with the algorithm from [56].

In Section 3.2 the background of the DiBu-model (Section 3.2.1) and of the DEMKit software (Section 3.2.2) are discussed. The implementation of the DiBu-model in the DEMKit simulation environment is discussed in Section 3.3. In Section 3.4 the implementation of the model is tested in a simulation of (part of) the neighbourhood in the Dutch village Heeten. Furthermore, in Subsection 3.4.3 the validity of the model and its implementation are tested by comparing the predicted SoC and power of one of the simulated batteries, to the SoC and power calculated from measurements on a corresponding actual battery. In Section 3.5 conclusions are discussed.

\footnotetext{
${ }^{1}$ Note that comparisons between the work presented in this chapter (models and simulator) and other possible solutions are beyond the scope of this chapter. These are covered for the simulator in [20] [71],[72] and for the model in: Chapter 2.
} 


\subsection{BACKGROUND}

In this section the relevant details of the DiBu-model and the DEMKit simulation software are discussed.

\subsubsection{The DiBu-Model}

The Diffusion Buffer model for battery State of Charge prediction (DiBu-model), has been discussed in Chapter 2. However, fore completeness, in this section a brief summary of the parts necessary for the implementation is presented. The state of charge, expressed as a percentage of the maximum SoC, is predicted by predicting the battery voltage during a charge, discharge or idle step in a future time interval. More precisely, the state of charge $\left(S_{o} C_{t}\right)$, at a time $t$ in the future is calculated using the following equation:

$$
S_{o} C_{t}=S_{o} C_{t^{\prime}}+\frac{\bar{U} \cdot \bar{I} \cdot\left(t-t^{\prime}\right)}{E_{\max }}
$$

where $S_{o} C_{t^{\prime}}$ is the SoC at a time $t^{\prime}$ before $t$, (so this is either a starting condition or a previously estimated value for the SoC), $\Delta t$ is the time difference between $t$ and $t^{\prime}$ (typically in the range of 1 second to 1 minute), $\bar{I}$ is the current during time interval $\left[t^{\prime}, t\right]$, which is known because it is supplied to or demanded from the battery, $E_{\text {max }}$ is the battery capacity given by the manufacturer and, lastly, $\bar{U}$ is the voltage during time interval $\left[t^{\prime}, t\right]$. To predict this voltage, four states of battery operation are used in the model: charging, discharging, idle after charging and idle after discharging, see also Figure 2.4. The separation between idle periods after charging and discharging is to account for the capacity recovery effect and the rate capacity effect, which are explained in [3]. For each of the four states an equation for $U_{t}$ is derived, see (3.2a) - (3.2d). These equations are used to model the battery voltage during the mentioned different states of operation; discharging (3.2a), idle periods after discharging (3.2b), charging (3.2c) and idle periods after charging (3.2d).

$$
\begin{aligned}
& U_{t}=U_{t^{\prime}}+\frac{\alpha \cdot \bar{I}}{S o C_{t^{\prime}}} \\
& U_{t}=U_{t_{0}^{\prime}}+\left(U_{\max }-U_{t_{0}^{\prime}}\right) \cdot\left(1-e^{-\frac{t-t_{0}^{\prime}}{\beta \cdot\left(t t_{0}^{\prime}\right)+\gamma}}\right) \\
& U_{t}=U_{t^{\prime}}+\frac{\bar{I}}{\delta} \\
& U_{t}=U_{t^{\prime}}
\end{aligned}
$$


In Equations (3.2a), (3.2c) and (3.2d), $U_{t^{\prime}}$ is the voltage at a time $t^{\prime}$ (before $\left.t\right), \bar{I}$ is the current during time interval $\left[t^{\prime}, t\right]$ which is known because it is applied to the battery, and $S_{o} C_{t^{\prime}}$ is the state of charge of the battery at the start of discharging. In Equation 3.2b, $t_{0}^{\prime}$ is the time at which the idle step starts, $U_{t_{0}^{\prime}}$ is the voltage at $t_{0}^{\prime}, U_{\max }$ is the voltage at the start of the discharge step, directly before the idle step. The parameters $\alpha, \beta, \gamma$, and $\delta$ are given constants and battery-specific. These parameters can be determined from measurements at the battery as has been discussed already in Chapter 2.

\subsubsection{DEMKIT}

DEMKit (short for Decentralized Energy Management toolKit) is a smart grid optimization and discrete time simulation software developed at the University of Twente $[20]^{2}$. The simulation framework follows a cyber-physical systems approach, wherein the interaction between control (optimization methods) and the physical devices and the grids can be analysed. DEMKit provides a library with components that model devices and grid assets. Furthermore, components containing control and optimization algorithms are available. By combining these components, a complete model of a smart grid consisting of many houses, and their devices, like e.g. batteries and electric vehicles, can be created and its total energy profile can be controlled and optimized.

Within DEMKit, the device components model the behaviour of a device, such as a battery or the stochasticity of a load. The tool works in an iterative fashion and in each iteration each device determines, based on the current state, its power consumption in the next time interval. Furthermore, at the start of a time interval, each device has (may have) to change the internal state based on the actions taken in the previous time interval. For example, a battery can update its SoC according to the energy consumed/produced during the previous time interval. All components are configurable through parameters, such as e.g. the capacity of a battery or the load profile of a device (e.g. for a washing machine). A controller can be connected to a device component to influence its behaviour. Herein, the device model is leading to ensure that the device is always operated in a valid state. The battery models currently implemented in DEMKit are generally ideal and loss free, whereas the DiBu-model takes losses into account (see Section 2.4).

Controllers within DEMKit have two main modes of operation, namely offline optimization for e.g. a day-ahead market and performing control on runtime to resolve deviations and disturbances. For the offline optimization the iterative profile steering heuristic [21] is used. This algorithm schedules a cluster of devices for $N$ future time intervals using a sliding window. Hereby, the heuristic makes use of predictions and the aforementioned device models. Within profile steering,

${ }^{2}$ DEMKit is the successor of the TRIANA smart grid simulation software, also developed at the University of Twente. In recent publications "DEMKit" is used to refer to the simulation software, while in earlier publications "TRIANA" is used. 
each device controller $m$ receives a steering signal $\vec{d}=\left[d_{1}, d_{2}, \ldots, d_{N}\right]^{T}$ containing the desired energy consumption for each of the $N$ intervals. The device controllers respond with an optimized energy profile $\vec{x}_{m}=\left[x_{m, 1}, x_{m, 2}, \ldots, x_{m, N}\right]^{T}$ of its device. An efficient algorithm to schedule batteries under these steering signals is presented by Van der Klauw et al. in [56]. More background on the profile steering algorithm can be found in the works by Gerards et al. [21] and Hoogsteen [20].

While performing the control on runtime, the device controller aims to realize the energy consumption/production planned for each time interval as specified in the offline optimization. Disturbances in predictions or model inaccuracies often result in situations where the planned energy consumption cannot be followed exactly. Hence, a strategy to minimize deviations from the planned schedule is required. To perform this control, the asynchronous event-driven profile steering mechanism is developed [72], which leverages the predictive nature of profile steering to balance short-term disturbances and long-term flexibility of devices. In this event-driven method, only one device is rescheduled at a time when necessary, e.g. when a deviation larger than a given threshold occurs. This reduces the complexity and required computation time, such that a new schedule is available within a few seconds.

\subsection{Implementation of the DiBu-Model}

To use the DiBu-model (Subsection 3.2.1) in a smart grid simulation and optimization framework, such as DEMKit, two steps need to be taken. The first step is to implement a discrete time model of the battery model, which represents the behavioural description of the battery. And, secondly, an optimization and control strategy suitable for the battery model needs to be developed. This section covers the implementation of these two aspects in the DEMKit framework.

\subsubsection{BATTERY MODEL}

The battery is modelled as a state machine. Each state within the model corresponds to one of the four states of operation described in the Section 3.2.1. The state transitions are determined based on the requested current from the battery and the previous state of the battery. In Figure 3.1 the four states and the different state transitions are given. The equation corresponding to each state $x \in\{a, b, c, d\}$ is given in Equation 3.2x. Note, that the state transitions depend only on the given current $\mathrm{I}$.

At each time step of a simulation, the voltage of the battery is updated based on the state of the battery. The following assumptions are made in this process. As within DEMKit only power is used, (i.e only the requested power from the battery) and no information on the current is given, the calculated voltage of the battery is used to determine the charging/discharging current from the requested power. 

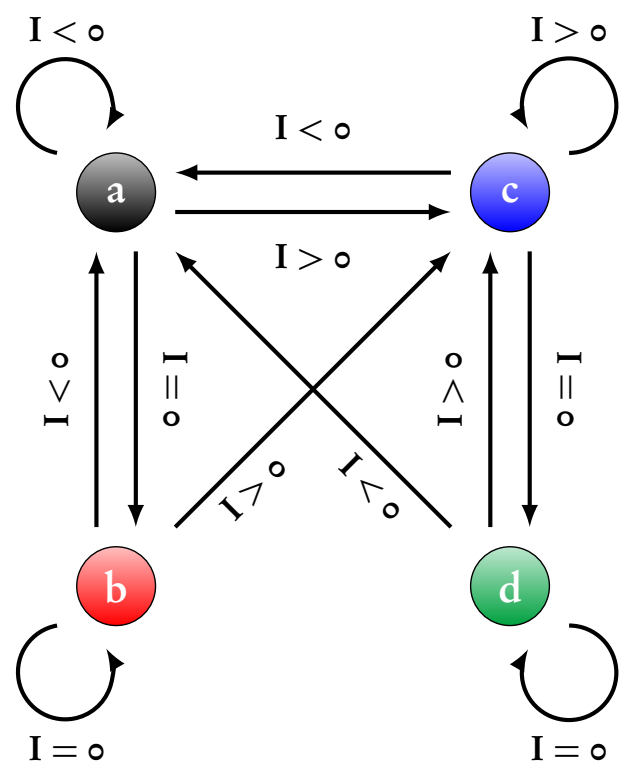

\section{a - Discharge \\ b - Idle after discharge}

c - Charge

d - Idle after charge

Figure 3.1: Schematic representation of the battery state transitions.

At each time step the minimum and maximum possible charging / discharging powers are updated according to the voltage of the battery. If the power requested from the battery in the optimization is either below the minimum or above the maximum charging powers, the requested power is set to this minimum or maximum possible charging power. If the voltage of the battery reaches its maximum (6.9 volts for the battery used in the simulations), charging of the battery is stopped, as continuing to charge would harm the battery. Also, if the battery is empty (so if the SoC falls below a certain threshold), the voltage is reset to its lowest safe-operating value ( 5.5 volts for the battery used in the simulations). Note, that in such situations a re-calibration of the model is possible.

\subsubsection{BATTERY CONTROLLER}

The aforementioned battery scheduling algorithm [56] is not directly applicable to the improved, more realistic battery model, introduced in this work, as this method is not able to cope with the changing power constraints. With the realistic battery model, the battery voltage varies based on the state, and therefore the maximum power consumption/production changes over time. However, initial simulation studies show that the difference in SoC between the ideal and realistic battery model only drifts slightly over time. Therefore, the scheduling 
algorithm from [56], that was based on an ideal battery model, is still used. However, to better suit the DiBu-model it has been extended with functionality to frequently retrieve the current SoC of the battery to track the mismatch between the current and the scheduled SoC. If this mismatch becomes too large, synchronization and rescheduling can be performed through signalling an event. In order to signal events for rescheduling, the mismatch is determined based on the SoC. For this, the planned battery power profile for a battery $b$ is used:

$$
\vec{x}_{b}=\left[x_{b, t+1}, x_{b, t+2}, \ldots, x_{b, t+N}\right]^{T}
$$

The profile is created at a time $t$ and specifies the energy $x_{b, i}$ for $i \in[t+1 \ldots t+n]$ which should be charged or discharged in the upcoming time periods $\bar{t}=t+$ $1, \ldots, t+N$. Based on this also the planned SoC in the future time intervals can be determined. Together with the initial SoC $\left(S_{o} C_{b, t}\right)$ at time $t$ of the planning, the planned $\operatorname{SoC}\left(S_{o} C_{b, \tau}\right)$ at time interval $\tau>t$ is then given by:

$$
S_{o} C_{b, \tau}=S_{o} C_{b, t}+\sum_{i=t}^{\tau-1} \frac{x_{b, i+1}}{E_{\max }}
$$

When the current state of charge of the battery $\left(S_{o} C_{b}\right)$ differs too much from the scheduled $\mathrm{SoC}$ at a time interval $\tau$, i.e. $\mathrm{SoC}_{b} \notin\left[\mathrm{SoC}_{b, \tau}-d, S_{o} C_{b, \tau}+d\right]$, an event is signalled to perform rescheduling. Hereby, parameter $d$ can be chosen arbitrarily to define the maximum allowed mismatch. In the simulations a deviation of $5 \%$ is used; i.e. $d=0.05$. Subsequently, the battery controller receives an updated desired profile $\vec{d}$ from its parent controller running profile steering. Furthermore, the controller synchronizes the maximum power consumption/production values (which depend on the current battery voltage) with the battery model. Subsequently, the controller re-plans the operation of the battery based on the updated constraints and the new steering signal.

\section{$3.4 \quad$ Results}

To validate the implemented battery model and control strategy, simulations are used. For this, one of the (optimized) battery charging profiles resulting from a simulation with DEMKit is programmed in the battery test equipment to compare and validate the simulated profile with measurements from a real battery.

\subsubsection{Simulation SEtup}

For the simulations performed within the DEMKit simulation toolkit a small neighbourhood (10 houses) was modelled using the artificial load profile generator presented in [71]. This neighbourhood consists of 5 families with children, 
4 young couples and 1 retired couple, all without flexible loads, such as electric vehicles or smart appliances. Each of the 10 houses was assigned one battery, for which the specifications will be discussed later (see Table 3.1). Furthermore, to test the energy sharing concept, 5 households got a PV setup, with the intention that a surplus of renewable energy generation of these PV installations is allowed to flow into all 10 batteries. Each house uses a Home Energy Management System (HEMS) running the profile steering algorithm to optimize the house's power consumption. The base load, PV and battery controllers communicate with the local HEMS. A cluster controller (also using profile steering) coordinates the energy profiles of all houses to allow energy sharing among the houses. The desired profile $\vec{p}$ for the neighbourhood is a zero-profile, i.e. $\vec{p}=[0,0, \ldots, 0]^{T}$, which implies that the goal is to achieve a balanced cluster where the sum of power consumption/production of all houses is zero for each interval. Furthermore, to avoid extreme peaks if total balance is not possible, the optimization objective is to minimize the Euclidean distance between this desired profile and the aggregated profile of all devices, i.e. to minimize: $\|\vec{p}-\vec{x}\|_{2}$, where the aggregated profile $(\vec{x})$ of all devices is:

$$
\vec{x}=\sum_{b=1}^{n} \vec{x}_{b}
$$

Hereby $\vec{x}_{b}$ is the profile of device $b$ and $n$ the amount of devices. More details on the optimization method and profiles can be found in the works by Gerards et al. [21] and by Van der Klauw [73].

The real battery available for verification is the Conrad battery for which the specifications are given in Table 3.1. Note that this battery only has a capacity of $43.2 \mathrm{Wh}(6 \mathrm{~V} \times 7.2 \mathrm{Ah})$, which is significantly lower than the batteries that would normally be used as a house battery. A more realistic capacity for the given setting would be $5 \mathrm{kWh}$. To take this difference into account, all load used for the simulation is scaled down by dividing the profiles by 115.7 (43.2 Wh / $5 \mathrm{kWh})$.

Table 3.1: Characteristics and parameters of the Conrad Battery used for the simulations.

\begin{tabular}{ll}
\hline \multicolumn{2}{c}{ Conrad Battery } \\
\hline Type & Lead-acid \\
Nominal voltage $(\mathrm{V})$ & 6,0 \\
Rated capacity $(\mathrm{Ah})$ & 7,2 \\
$\alpha(\mathrm{V} / \mathrm{A})$ & $3,030 \times 10^{-5}$ \\
$\beta(-)$ & 0,268 \\
$\gamma(\mathrm{s})$ & 2,684 \\
$\delta(\mathrm{A} / \mathrm{V})$ & $2,438 \times 10^{4}$ \\
\hline
\end{tabular}


Two simulations are run, one with the original ideal battery model for comparison and one with the realistic battery model presented in Section 3.4.2. As a validation the results are also compared with measurement results of a real battery (Section 3.4.3). The simulations consider one week (week 13 from the generated profile) in discrete time intervals of 1 minute. Optimization is performed in intervals of 15 minutes where a sliding window approach is used. Each day, the energy profile for two days into the future (192 intervals) is optimized to avoid boundary effects at the end of the day. The batteries are initialized completely discharged (i.e. $\mathrm{SoC}=0$ ) for convenience during the verification.

\subsubsection{Simulation Results}

In a first step, the performance of the realistic battery model is evaluated by comparing its results with the results of the original ideal battery model. The two models lead to slightly different optimization results, where the realistic model favours charging the battery a bit more on average, which results in a slightly higher average power consumption $\left(P_{\text {avg }}\right)$ for the whole neighbourhood of 10 houses and an higher average $\mathrm{SoC}\left(\mathrm{SoC}_{\mathrm{avg}}\right)$. In Table 3.2 an overview of the simulation results for the simulation with the ideal battery model (ideal) and the former battery model (realistic) is given. And in Figure 3.2 a plot of the $S_{o} C_{\text {avg }}$ for both simulations is given. The plots in Figure 3.2 show that the SoC of the realistic battery model is generally higher than that of the ideal battery model, however both profiles follow the same daily pattern. In this figure it can also be observed that the SoC of the batteries gradually rise, due to a surplus of energy in the neighbourhood.

In a second step, the performance of the realistic battery model is evaluated with the planning made during the optimization process. In Figure 3.3 the planned power profile $\left(\mathrm{pp}_{\text {planned }}\right)$ and the realized power profile with the realistic $\left(\mathrm{pp}_{\text {realistic }}\right)$ battery model for the whole cluster are shown. Additionally, the power profile with the ideal battery model $\mathrm{pp}_{\text {ideal }}$ is also shown for comparison. In general the profile are quite similar. A few larger deviations between $\mathrm{pp}_{\text {planned }}$ and $\mathrm{pp}_{\text {realistic }}$ are mainly observed in the first days of the simulation. Over the course of a couple of days, the mismatch is reduced significantly. Moreover, mismatches in the SoC do not affect the cluster performance as the capacity of the batteries is never completely utilized. Thus, despite these mismatches in the $\mathrm{SoC}$, the batteries always provide flexibility to resolve planning inaccuracies. As a result, the planning for the neighbourhood as a whole can be followed accurately.

A comparison between the power values and the resulting SoC of the planning and the realistic battery model is given in Table 3.3. For both values ( $\mathrm{P}$ and $\mathrm{SoC}$ ) the mean absolute error (MAE) is given per day of the complete week, for $\mathrm{P}$ the root mean square error (RMSE) is also given. The low $\mathrm{P}_{M A E}$ (over-all $\leq$ $2 \mathrm{~W}$ ) indicates that on average the deviation between $\mathrm{pp}_{\text {planned }}$ and $\mathrm{pp}_{\text {realistic }}$ 


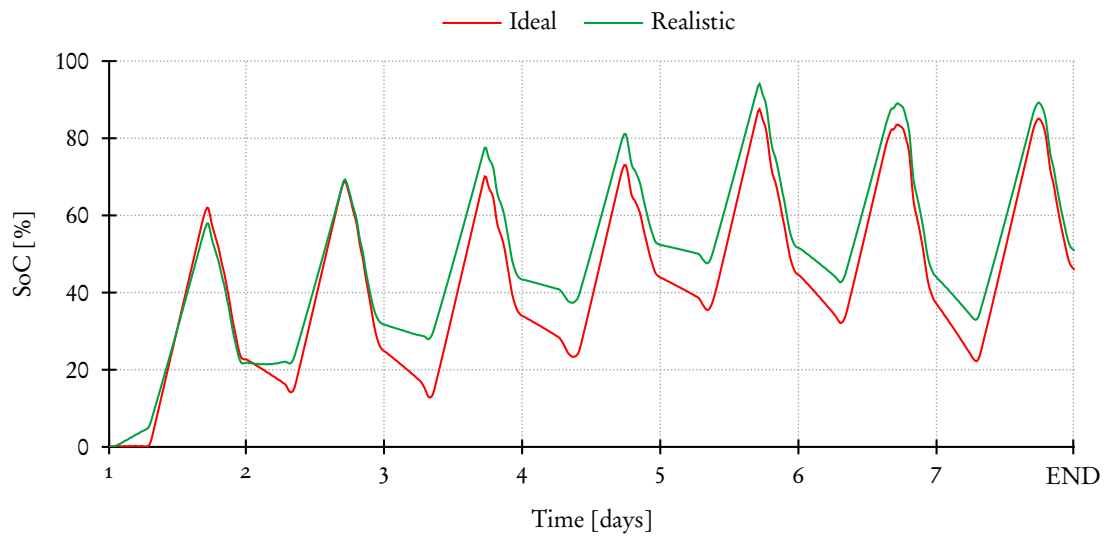

Figure 3.2: Average state of charge of the batteries

Table 3.2: Numerical results of the simulation case studies

\begin{tabular}{r|cccc}
\hline & $P_{\max }$ & $P_{\min }$ & $P_{\text {avg }}$ & $S o C_{\text {avg }}$ \\
\hline Ideal & $25.0 \mathrm{~W}$ & $-127.5 \mathrm{~W}$ & $-5.5 \mathrm{~W}$ & $42.4 \%$ \\
Realistic & $27.3 \mathrm{~W}$ & $-132.1 \mathrm{~W}$ & $-5.3 \mathrm{~W}$ & $49.2 \%$ \\
\hline
\end{tabular}

is quite small compared to the used power interval $[\sim-130, \sim 30] \mathrm{W}$. The $\mathrm{P}_{R M S E}$ is over-all $\leq 3.3 \mathrm{~W}$, this indicates that no extreme deviations between $\mathrm{pp}_{\text {planned }}$ and $\mathrm{pp}_{\text {realistic }}$ occur, as over-all the $\mathrm{P}_{R M S E}$ is not much larger than the $\mathrm{P}_{M A E}$. The SoC $\mathrm{S}_{M A E}$ is also quite low, $\leq 1 \%$ over-all, indicating that there is very little deviation between $\mathrm{SoC}_{\text {planned }}$ and $\mathrm{SoC}_{\text {realistic }}$. Furthermore, it is observed that only few event-driven replanning operations were required during the simulations, this indicates that the $\mathrm{SoC}_{\text {realistic }}$ does not differ significantly from the $\mathrm{SoC}_{\text {planned }}$.

In Figure 3.4 the average power profile of the batteries is shown. It is immediately clear that the realistic battery model is able to closely follow the planned power output, in contrast to the ideal model which shows larger deviations. Note, that the power constraints of the realistic battery model depend on the SoC and voltage and that these values match the specifications given in Table 3.1 best at a SoC of $50 \%$. These constraints are taken into account during the optimization process in the planning executed for each day. Hence, smaller errors are observed when the SoC is close to $50 \%$ at the moment the planning is created. This occurs from day 4 onwards, as the SoC is $\sim 50 \%$ at the start of the day, when the daily optimization process is executed. 


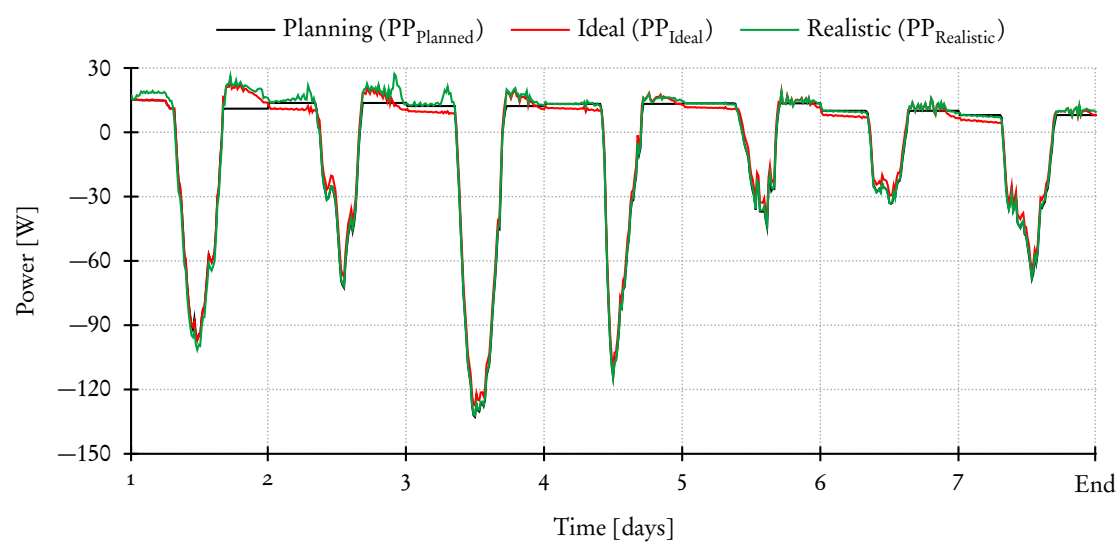

Figure 3.3: Power profile of the neighbourhood of 10 scaled households including the planning for the realistic battery model case.

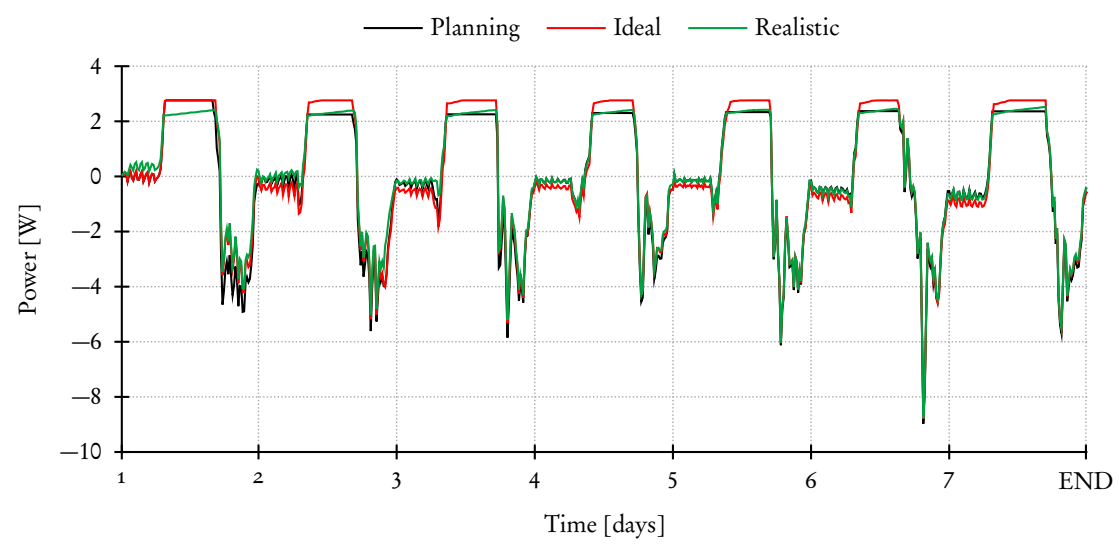

Figure 3.4: Average power consumption and production of the batteries, including the planned power profile for the realistic battery model case. 
Table 3.3: Mismatches between the planning and the realistic battery

\begin{tabular}{r|cccc}
\hline Day & $P_{\mathrm{MAE}}$ & $P_{\mathrm{RMSE}}$ & $S_{0} C_{\mathrm{MAE}}$ & $S_{0} C_{\text {start }}$ \\
\hline $\mathbf{1}$ & $5.61 \mathrm{~W}$ & $6.48 \mathrm{~W}$ & $0.93 \%$ & $0.0 \%$ \\
2 & $2.80 \mathrm{~W}$ & $4.09 \mathrm{~W}$ & $0.95 \%$ & $21.8 \%$ \\
3 & $2.14 \mathrm{~W}$ & $3.20 \mathrm{~W}$ & $0.97 \%$ & $31.6 \%$ \\
4 & $1.00 \mathrm{~W}$ & $1.46 \mathrm{~W}$ & $0.77 \%$ & $43.3 \%$ \\
5 & $0.62 \mathrm{~W}$ & $1.02 \mathrm{~W}$ & $0.87 \%$ & $52.3 \%$ \\
6 & $0.92 \mathrm{~W}$ & $1.42 \mathrm{~W}$ & $0.91 \%$ & $51.4 \%$ \\
7 & $1.08 \mathrm{~W}$ & $1.41 \mathrm{~W}$ & $1.04 \%$ & $45.6 \%$ \\
All & $2.03 \mathrm{~W}$ & $3.30 \mathrm{~W}$ & $0.92 \%$ & - \\
\hline
\end{tabular}

\section{$3 \cdot 4 \cdot 3$ VALIDATION}

In this subsection the performance of the implemented DiBu-model itself is evaluated. The simulation yields a realized power profile for the batteries (Figure 3.4), which can be used to predict the SoC of the battery (Figure 3.2). To validate these simulation results, a comparison was made between the predicted SoC and power, and the SoC and power derived from measurements on the actual battery. The battery, for which the specifications are given in Table 3.1, was subjected to the desired power profile, and the voltages and currents were measured and used to derive the actual power profile and the actual SoC. Note that the desired power profile for the real battery is the realized power profile from the simulation results.

All measurements are done using a CADEX C8000 battery analyser [64]. This device has to be programmed manually, therefore the power profile for only one day (day 5) was chosen for this validation. The desired power profile, that was obtained from the simulation in DEMKit and used in this validation is displayed in Figure 3.5. However, to accommodate for the sensitivity of the battery analyser the programmed supplied and demanded currents were rounded to the nearest $10 \mathrm{~mA}$. Moreover the sensitivity of the battery analyser was such that charge or discharge currents below $50 \mathrm{~mA}$ could not be achieved accurately. To remedy this, currents of $25 \mathrm{~mA}$ and lower were set to $\circ \mathrm{A}$ and currents between $25 \mathrm{~mA}$ and $50 \mathrm{~mA}$ were set to $50 \mathrm{~mA}$.

In Figure 3.5a an overview of the desired power profile and measured power profile are displayed. Between time index 8:00 and 17:30 and between time index 19:00 and 8:00 the desired power profile and the measured power profile are almost indistinguishable. To better show the differences between the power profiles, two parts of the graph are displayed on a larger scale in Figures 3.5 b and 3.5c. From these detailed graphs it is immediately clear that the desired power profile and the measured power profile are nearly identical. The maximum difference between the desired power profile and the measured power profile is 


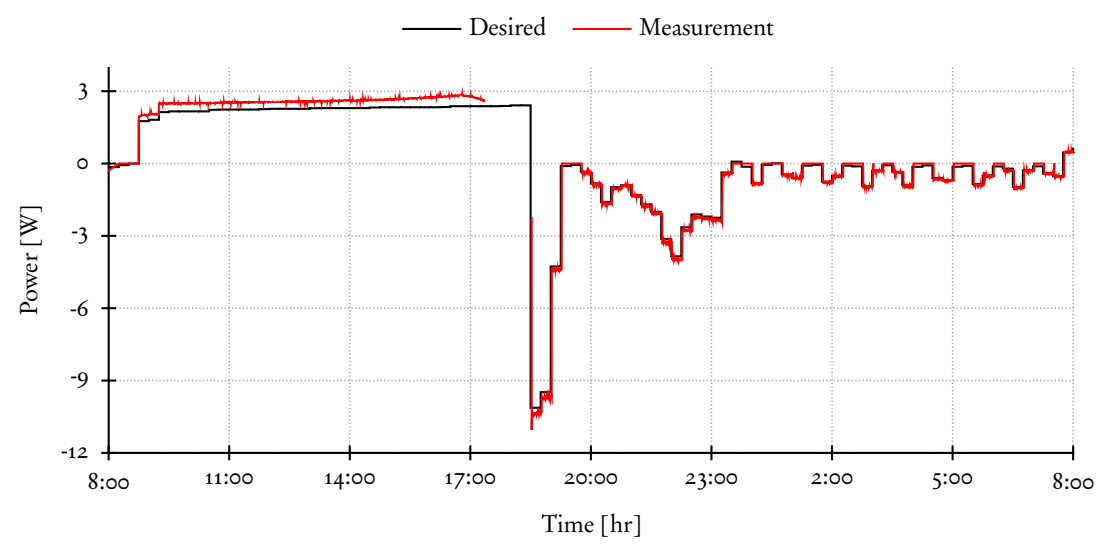

(a) Full day simulation

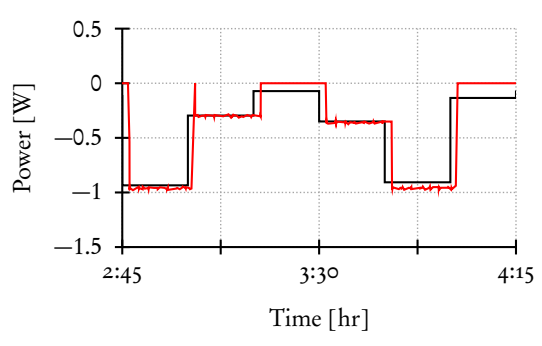

(b) Detail: 2:45 - 4:15

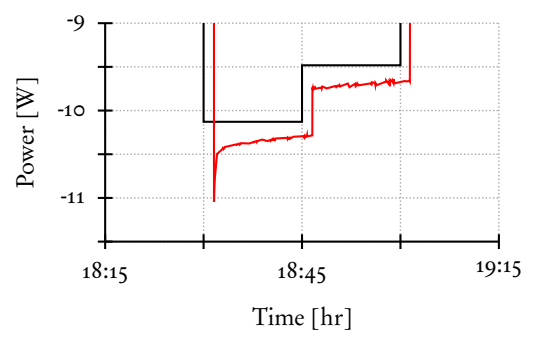

(c) Detail: 18:15 - 19:15

Figure 3.5: Desired power profile of one battery in the neighbourhood, compared to the power profile for the same battery, derived from the measurements.

$0.46 \mathrm{~W}$, at 17:00. After 19:00 the maximum difference is about $0.1 \mathrm{~W}$. Between time index 17:30 and 19:00 there are no measured power values. This is caused by a problem during the measurement. At the start of the indicated time interval the battery voltage was too high, this prompted the equipment to protect the battery by keeping it idle until a next discharge step occurred. This has been indicated in the graph, by a missing part of the measured power profile line. It is likely that the high voltage is caused by degradation of the battery, as this battery had been used already before, for many measurements. Summarizing, in the periods where measurements are available the desired and measured power profiles are quite similar, although the accuracy is better for negative power values (i.e. discharging).

The predicted SoC (SoC ${ }^{\mathrm{DiBu}}$ ) and the SoC calculated from the measurements $\left(\right.$ SoC $\left.{ }^{\text {meas }}\right)$ are compared in Figure 3.6. Apart from the interval between 17:30 and 19:00 the SoC ${ }^{\text {meas }}$ matches the SoC ${ }^{\mathrm{DiBu}}$ very well. From 8:00 to 17:30 the difference between the $\mathrm{SoC}^{\mathrm{DiBu}}$ and the $\mathrm{SoC}^{\text {meas }}$ is negligible. The largest devi- 


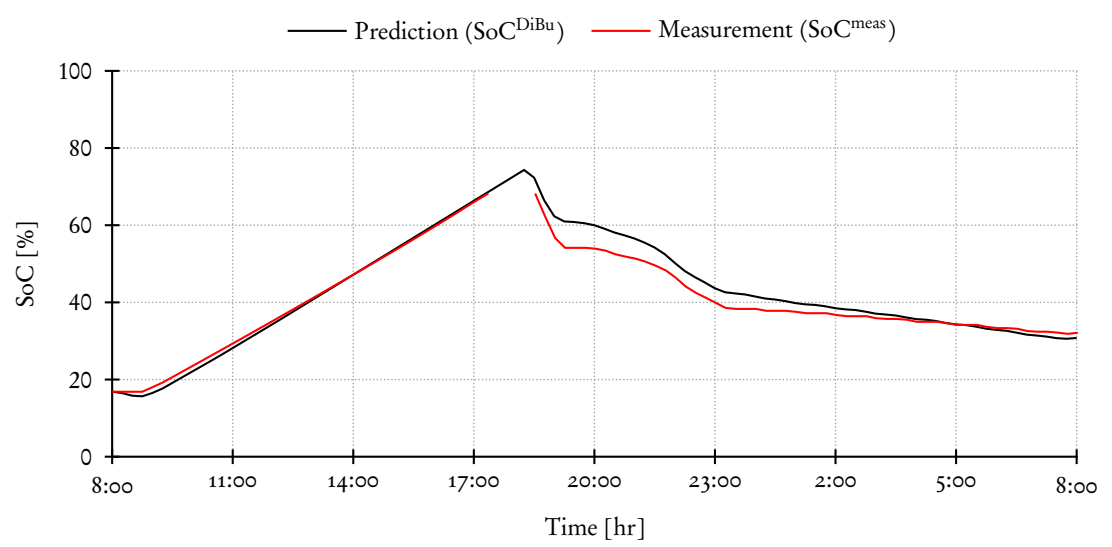

Figure 3.6: Predicted SoC of one battery in the neighbourhood, compared to the SoC of the same battery, calculated from the measurements.

ation between the SoC $C^{\mathrm{DiBu}}$ and the $\mathrm{SoC}^{\text {meas }}(6,6 \%)$ is observed around 19:30. At this moment a power peak of $10 \mathrm{~W}$ is drawn from the battery. From 19:30 onward the difference decreases and between 5:00 and 8:00 the difference is no larger than $1.5 \%$. So the measured power matches the desired power profile quite closely. Hence, the results from the simulation using the realistic battery model give a quite realistic view on the behaviour of the battery.

\section{$3 \cdot 5$ CONCLUSIONS}

In this chapter the integration of the DiBu-model within the simulation and optimization software DEMKit is presented. It is shown that the DiBu-model is quite suitable for use with the DEMKit simulation software. It is also demonstrated (Figure 3.3 and 3.4) that the power profiles realized with the DiBu-model match the planned power profiles quite closely, in some instances even more closely than the power profiles realized with the ideal model. It was also demonstrated (Figure 3.5) that the power profiles realized with the DiBu-model match the realistic behaviour of the battery quite well. Comparisons between the predicted SoC and the SoC calculated from measurements show that the predictions made using the $\mathrm{DiBu}$ model match reality quite well. The difference between the DiBu-model prediction and the SoC $\mathrm{C}^{\text {meas }}$ is generally less than $1,5 \%$. Only in the time interval where the largest amount of power is demanded from the battery, the deviation between the predicted SoC and SoC ${ }^{\text {meas }}$ increases. Summarizing, the application of the DiBu-model results in an improved accuracy of the simulation results. 


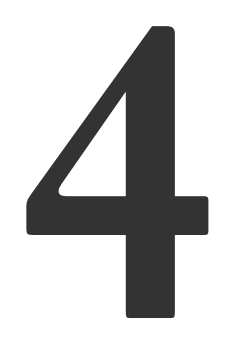

\title{
The 16 houses CASE, INTEGRATION OF BATTERIES IN A NEIGHBOURHOOD MICROGRID
}

\begin{abstract}
In this chapter the integration of batteries in a smart microgrid is studied. More specifically the possibilities of "soft-islanding" (near autarkic behaviour) a microgrid with 16 houses in the Netherlands is investigated using the DEMKit simulation toolkit. For this research an idealistic "greenfields" neighbourhood is used where energy is generated by PV-panels as well as by a CHP and energy is stored using batteries as well as a heat buffer. In a first step the proper size for the equipment is determined based on energy production and consumption data of several weeks in the year. Secondly one year simulations for several scenarios are presented and the degree of autarky for each scenario is compared. It is demonstrated that a (nearly) autarkic operating microgrid can be achieved, with a proper and realistic sizing of the components. Combining this proper sizing of energy generation and storage assets, with an advanced control, it is possible to achieve a degree of autarky (DoA) above 99\% over a year, meaning that less than one percent of the energy has to be imported from the main grid. Subsequently the tools and methods used for the greenfields neighbourhood are applied to a simulation of a real neighbourbood in a case-study. For this real neighbourhood of Markluiden it is possible using advanced control and storage devices to reach a DoA of $91.1 \%$ over a year.
\end{abstract}

Parts of this chapter have been previously published in [H:1], [H:7] and [H:8]. 


\subsection{INTRODUCTION}

With the current Energy Transition in the Netherlands, a country-wide operation is ongoing aiming at a structural change in energy usage to drastically reduce the $\mathrm{CO}_{2}$ emission in the country [3]. One of the intended steps in the energy transition is to drastically reduce the usage of natural gas industrially, commercially and domestically. Focusing on domestic usage, most homes in the Netherlands are connected to the natural gas grid and this gas is used for space heating as well as domestic hot water (DHW) and for cooking [7]. As a result, currently most residences in the Netherlands are dependent on natural gas. Simply switching to all electrical appliances is a difficult and costly process, for the end users as well as the network operators as the national electrical grid in the Netherlands is not designed for the resulting increase in electricity usage $[8,9]$.

To tackle the energy transition, i.e. moving away from natural gas, there are two important other developments. On the one hand demanding loads, such as electric vehicles and heat pumps, may provide some flexibility to the system, e.g. by controlling the time for charging the electric vehicles or by using the thermal mass of the houses to control the heat-pumps. The objective of this control may e.g be to perform peak-shaving. Several control and optimization methods for energy management in the electricity systems are proposed in literature as surveyed by Siano [74]. In such a system, consumers receive incentives to which they can react in order to avoid overloading or to increase the local consumption of renewable energy. However, the resulting effects depend heavily on the type of incentive used. McKenna and Keane [75] evaluated different incentive schemes and found that several uniform pricing schemes result in peak shifting rather than peak shaving if enough flexibility is provided. Furthermore, Nykamp et al. [76] state that steering by global market prices does not always reflect the local state of the grid and therefore may amplify negative effects on a local level. As a result, such schemes may even result in the need for more distribution and transmission capacity instead of a reduction.

On the other hand, locally produced energy may be used to reduce the burden for the electricity grid. For this an operational control is needed which supports the consumption of as much locally produced energy as possible near to its generation [77]. In the scope of the electricity grid in this context the term microgrid was established, which was first coined by Lasseter [17]. A microgrid is a part of the electricity distribution grid that has the ability to temporarily disconnect from the national grid. This disconnected operation is called islanded operation of a microgrid and improves the resilience of a grid by e.g. temporarily operating autarkic in case of failures in higher level parts of the grid hierarchy. Furthermore, in connected mode, a microgrid is able to provide ancillary services to the power grid such as acting as a virtual power plant [78]. Various control approaches for microgrids have been presented in literature, see e.g. [79, 80]. However, most control concepts mainly focus on stabilization of islanded micro- 
grids, which often leads to the implementation of a simple greedy strategy, which may result in high import and export peaks in terms of power. Another extreme is to create a fully islanded microgrid. However, this is in general an appealing but also costly solution. Here a solution between the extremes is considered, by (nearly) islanding a microgrid from a power import and export perspective, but keep the grid connection for stabilization. This avoids high investments associated to frequency balancing systems. For the mentioned approach, internally predictive and planning based control strategies are required to maximize the self-consumption of energy, and at the same time to minimize power peaks, see e.g. $[21,58]$. Such a connected microgrid is able to also act as a good citizen towards the national grid as it can defer associated grid investments.

Next to electricity, also other energy carriers such as heat and gas should be integrated. Mancarella [81] has surveyed concepts and models for such integrated multi-energy systems (MES), where the general conclusion is that a well organized MES is able to benefit from the synergies between the different energy sources and consumers. Economic optimization frameworks are proposed in [82] and [83], which show that a MES has indeed economic advantages. A trade-off between market optimization and local peak reduction using model predictive control in a MES is studied by Long et al. [84]. Their system uses a combined heat and power (CHP) unit, a heat pump and a storage to provide flexibility. They conclude that also for MES other incentive schemes are required to make a positive business case for local peak reduction, which agrees with the conclusion of [76]. Note that the choice of a proper MES solution may be very climate specific. For example Perez et al. [85] consider a Texas based MES. Where cooling is dominant instead of heating. Although their setting is quite different as MES solutions for heating dominated cases, they come to similar conclusions concerning the energy market.

In previous work [H:1] a MES of 16 houses was analysed to explore the possibilities of operating that particular MES independent from the electricity grid. From the results it was concluded that complete independence from the electricity grid was infeasible, however, it was also concluded that operating this MES grid-connected but only using that connection for a small fraction of the time, would be feasible. The therm "soft-islanding" was coined to describe this form of nearly islanded microgrid. Because this chapter is based on and (to some extent) influenced by that previous work. Therefore, first a brief summary of this case and its results and conclusions is given. 
The neighbourhood considered in [H:1] consists of 16 houses. A schematic overview of the relevant available energy systems is given in Figure 4.1.

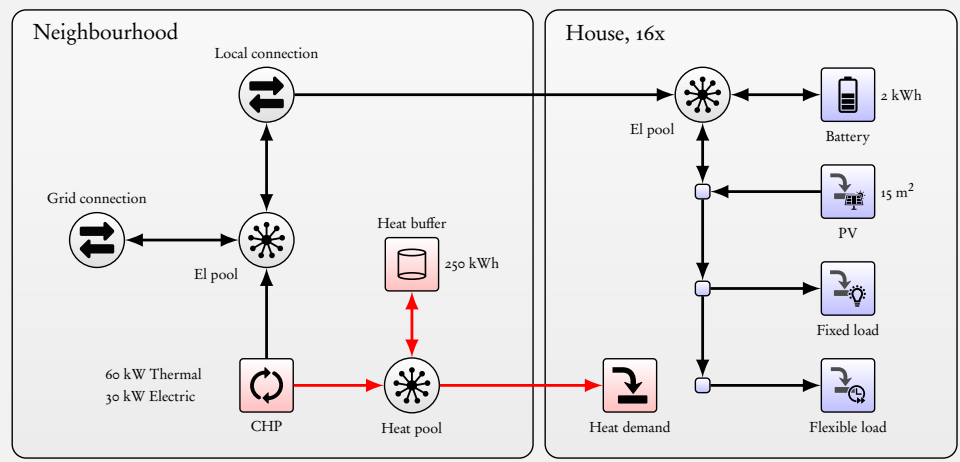

Figure 4.1: Schematic representation of the neighbourhood energy system.

Each house has PV-panels, of which 50\% are faced south, $25 \%$ faced west and $25 \%$ faced east. All PV-panels are placed at a $35^{\circ}$ angle and have a $16 \%$ efficiency. To calculate the produced electricity weather data from [86] and the methods discussed in $[87,88]$ are used. Each house also has a battery and the houses share one common CHP and heat buffer. The latter are used to meet the heat demand of each house.

The heat demand for each house is calculated using models outlined in [89]. On average each house has a heat demand of $28 \mathrm{GJ} /$ year of which 18 $\mathrm{GJ}$ is for space heating and $10 \mathrm{GJ}$ for hot water. The electricity demands are divided between fixed loads and flexible loads. The fixed loads consist of devices that are switched on when needed (e.g. a lamp or a coffee maker) and devices that are always on in the background (e.g. a modem). The profiles for fixed loads are generated artificially using smart-meter data measured during a field-test [41] and are based on occupancy, activities and age of the persons in the household. A unique profile is generated for each house, whereby on average $7.6 \mathrm{kWh}$ is used daily in each house. The flexible loads consist of two time-shiftable devices per house (e.g. a washing machine and a dishwasher), for which the profiles are obtained from [90]. The fixed and flexible loads combined use a total of $10.2 \mathrm{kWh}$ per house per day.

A model of the MES in the neighbourhood was created in the TRIANA 
simulation software $[59,70]$ using the aforementioned specifications. The proper size of the CHP, battery and PV-panels was determined in an iterative process. The equipment used in the final simulation is a shared 60 $\mathrm{kW}_{\mathrm{th}} / 30 \mathrm{~kW}_{\mathrm{el}} \mathrm{CHP}$ unit with a $250 \mathrm{kWh}_{\mathrm{th}}$ buffer, and for each house 15 $\mathrm{m}^{2} \mathrm{PV}$-panels and a $2 \mathrm{kWh}$ battery.

The energy usage for the neighbourhood MES was simulated for three different scenarios:

- Reference scenario (BASECASE) - In this scenario, no battery is used and no smart-control is implemented. The CHP is controlled to just meet the heating demand by maintaining a sufficient stateof-charge of the thermal storage.

- Optimal control scenario (CON) - In this scenario, smart-control of domestic appliances is applied. The controller decides the start times of the time-shiftable devices and the operation of the CHP and the optimization strategy of the controller is to flatten the energy profile for the community of houses such that there is a minimal electricity input from the grid. The CHP is controlled to meet the heating demand, but can also be used to meet the electricity demand.

- Optimal control with batteries scenario (CON/BAT) - In this scenario, also smart-control of domestic appliances is implemented, but additionally each house is given a battery storage system. The optimization strategy and CHP control is the same as in the CON case.

The simulation of the MES was done for an entire year, whereby the results for three interesting weeks were studied in detail:

- Week 4 (20-26 January) in which the heat demand was very high while the energy production from the PV-panels was low.

- Week 31 (28 July - 3 August) in which the heat demand was low while the energy production from the PV-panels was very high.

- Week 43 (20 - 26 October) in which both the heat demand and energy production from the PV-panels were low.

The simulation results for the three scenarios during the three weeks are presented in Figure 4.2. The results for Week 4 show that in each scenario the CHP is always producing electricity (see Figure $4.2 \mathrm{~b}$ ). This is caused by the high heat demand during that week. In the BASECASE scenario large amounts of power are exported to the grid, whereby during the nights of day 2 and 4 this peaks to $30 \mathrm{~kW}$. However, during the days there is still a limited demand from the grid (see Figure 4.2a). In both the CON 
and CON/BAT scenarios power is only exported to the grid, with only marginal differences between the two scenarios.

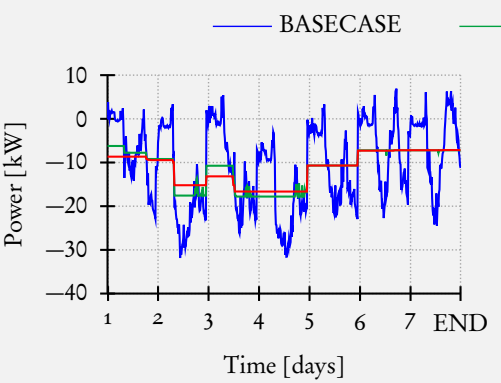

(a) Week 4: Grid power demand

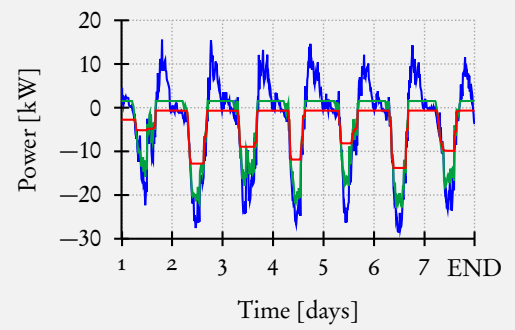

(c) Week 31: Grid power demand

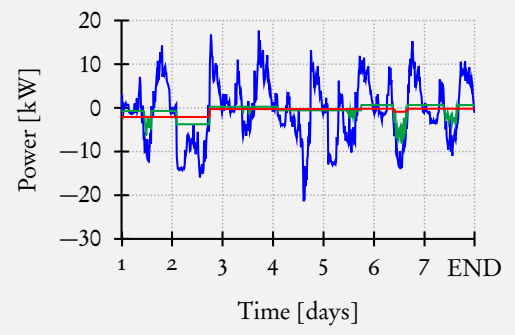

(e) Week 43: Grid power demand
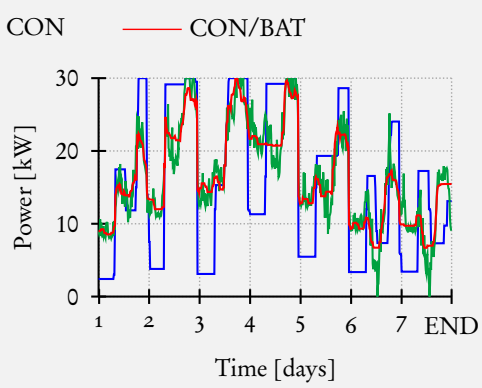

(b) Week 4: CHP power

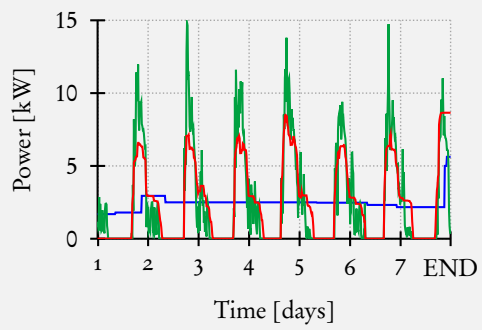

(d) Week 31: CHP power

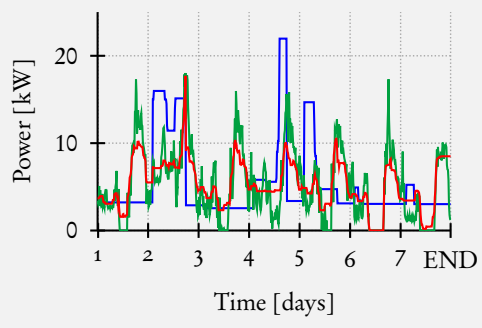

(f) Week 43: CHP power

Figure 4.2: Simulation results for weeks 4, 31 an 43; (a), (c) and (e) The total grid power demand for the neighbourhood, note that a negative demand is actually power delivered back to the grid. (b), (d) and (f) The power generated by the CHP.

The results for Week 31 (Figure 4.2d) show that in the BASECASE scenario the CHP is constantly producing electricity on a low level $(\sim 2.5$ $\mathrm{kW})$. This is caused by the low heat demand during this week. In the 
$\mathrm{CON}$ and CON/BAT scenarios electricity is only produced during the evenings and nights, while there is no production during the day. This is a result of the better control of the CHP. Although, in the CON and $\mathrm{CON} / \mathrm{BAT}$ scenarios the production during the nights is higher than in the BASECASE scenario, the overall production is lower. From Figure $4.2 \mathrm{c}$ it is immediately clear that during this week electricity generated by the PV-panels dominates the grid power demand. In all scenarios power is exported to the grid during the day. In the BASECASE and CON scenario power is demanded from the grid during the night, although due to the application of smart-control in the CON scenario this demand is kept to a minimum. In the CON/BAT scenario, the usage of batteries ensures that no power is demanded from the grid, however there still is a significant amount of power exported to the grid.

In week 43 the simultaneous occurrence of a low heat demand and a low production by the PV-panels, provides some difficulties. Figure 4.2e shows that there is a very irregular power demand from the grid in the BASECASE scenario. In both the CON and CON/BAT scenarios there is almost no power demanded or delivered back to the grid. However, this flat profile is achieved only because the CHP is used extensively to meet the electricity demands in addition to the heat demands.

It is concluded that:

- With optimal control the 16 house neighbourhood is already able to function as a microgrid (the CON scenario).

- With optimal control and a $2 \mathrm{kWh}$ battery system per house the microgrid can be almost electrically independent (the CON/BAT scenario).

- In each scenario there are significant power exports to the grid.

- A grid connection is still needed, although mainly to export power.

The work [H:1] provides valuable insights and interesting results. It indicates that $15 \mathrm{~m}^{2}$ PV-panels and a $2 \mathrm{kWh}$ battery per house, in addition to a shared $60 \mathrm{kWh}$ th (thermal) / $30 \mathrm{kWh}$ (electric) CHP with a $250 \mathrm{kWh}$ heat buffer, is enough to achieve semi-autonomous operation from the grid. However, the results of this case-study are obtained with ideal, loss-free, models and the optimization methodology used perfect predictions of energy consumption. Furthermore, in the light of recent advances of the simulator [20], the optimization algorithms [73] and the models for heat demand [29] and battery SoC [H:6], the setup of the system and the used models in [H:1] are quite simple. Moreover, it is not completely clear if the achieved results are realistic and are valid under all conditions. 
Based on the considerations above it was decided to revisit the original case study, presented in [H:1] with the aim to use refined models to obtain more realistic results under challenging conditions. These refined models include the addition of first order thermal models, an advanced and validated battery model, and a synthetic load-profile that is validated using measurement data collected from a field-test. Also the optimization algorithms are improved to use real predictions, whereas the control mechanism now also deals with prediction errors that arise.

The goal of this research is to determine better settings of the required local generation and storage units to make soft-islanding possible under realistic circumstances. For this a futuristic "greenfields" scenario is used, with full flexibility to arrange the layout of the neighbourhood and use best-practices in construction of houses, such as e.g. a low-temperature floor heating system and using high insulation standards. To achieve a more realistic approach to size the soft-islanded neighbourhoods, first a scenario with fixed parameters for the considered devices is defined. For this scenario a parameter sweep is executed using the DEMKit simulation and demonstration toolkit [20]. The parameters for which this sweep is executed are the PV-panel area, the battery capacity and the heat to electricity ratio of the CHP (discussed in Section 4.3). Based on the appropriate sizes for each of these components, different control strategies ([21] and [91]) are used to evaluate the setting.

This chapter is organized as follows. Section 4.2 introduces terminology and presents the research method, including the used software, parameters and models. A case description of the neighbourhood is given in Section 4.3. The sizing of all components, using a simultaneous sizing approach is described in Section 4.4. In Section 4.5 the results of simulation studies are presented and in Section 4.6 a case study where the method is applied to an actual neighbourhood in Markluiden, the Netherlands, is discussed. The over-all conclusions are presented in Section $4 \cdot 7$.

\subsection{Tools \& Methods}

In order to evaluate whether or not a microgrid can be considered as being soft-islanded, a clear definition of soft-islanding is required. As stated in the introduction, a soft-islanded grid should be able to operate nearly autarkic, i.e. the exchange of energy with the main grid should be minimal and ideally even should be zero. Furthermore, customers connected to the microgrid should not experience drawbacks of being connected to such a soft-islanded microgrid compared to a conventional grid. Hence, measures as e.g. load shedding are not an option, as comfort of end-users must be preserved.

To define soft-islanding, the focus is on the energy that is locally produced and therefore in principle does not need to be imported from the main grid. A frequently used term for this is the self-consumption, which is defined as the ratio between the energy consumed directly in the microgrid and the total produced 
energy. This metric is quite straight-forward, the higher the self-consumption, the more energy consumed was produced locally. However, the drawback of this metric is that it also can result in a low value when an overcapacity of energy producing devices (e.g. PV) is installed. For example, if more energy is produced locally than could possibly be consumed locally, this would result in a low selfconsumption, even though all energy consumed was produced locally. Using this metric could lead to unjust comparisons and wrong conclusions.

Another metric that could be used to compare different solutions is the Demand Cover Factor ${ }^{1}$ (DCF) as formulated by e.g. Palacios-Garcia et al. [94]. However the DCF as introduced is not completely suitable for the considered situation, since it only uses PV as a source of local energy generation. As the focus of this paper is on MES with multiple sources, a generalized metric is introduced that is technology independent: the Degree of Autarky (DoA). The DoA is defined as the percentage of energy consumption $\left(\mathrm{E}_{\text {consumption }}\right)$ from local sources, i.e.

$$
\operatorname{DoA}=\frac{\mathrm{E}_{\text {consumption }}-\mathrm{E}_{\text {import }}}{\mathrm{E}_{\text {consumption }}} \times 100 \% \text {, }
$$

where $\mathrm{E}_{\text {import }}$ is the total amount of imported energy. In contrary to the selfconsumption, the DoA value does not decrease when overproduction (the part that is being exported) is installed. Note, that by increasing the matching of supply and demand within the microgrid, e.g. by using a storage device, the DoA can be increased.

To consider a microgrid to be soft-islanded, the DoA should be close to $100 \%$. However, note that the last few percent points to reach a DoA of $100 \%$ usually lead to very high investments, such as large batteries, of which the full capacity is only used in rarely occurring situations. Based on this, the aim is a DoA of at least $98 \%$, which means that the neighbourhood needs to import electricity from the grid for at most a total of one week in the year. Furthermore, with the ongoing electrification in mind, the focus is only on the interaction with the electricity grid. It is assumed e.g. that abundant (bio) fuel is available in the vicinity to power a CHP.

Although, the DoA is a useful Key Performance Indicator for the analysis of a microgrid, its optimization should not be a goal in itself. The DoA is determined from a (mostly) technical analysis and can be used to express the effect of adding e.g. decentralized electricity generation or storage to a microgrid, in terms of grid dependence. However, the DoA can also be used to help express the effect of adding the aforementioned devices to a microgrid in terms of financial cost, or $\mathrm{CO}_{2}$ emissions, if the proper financial costs or $\mathrm{CO}_{2}$ emissions are assigned to the devices used in (or added to) a microgrid.

\footnotetext{
${ }^{1}$ In literature this metric is also referred to as Load Cover Factor [92] and Load Match Index [93].
} 


\subsubsection{THE LOAD PROFILES}

A crucial factor for the simulations is the input data. Here, large parts of the required data is associated with the electricity and heat demand of the 16 houses. This type of data generally is not readily available, and even when it is, it is privacy sensitive and its usage is restricted by privacy laws and regulations. Therefore statistics or models are used to generate artificial profiles for the electricity and heat demand of households. A comprehensive review by Torriti [95] outlines that many different methods and approaches to obtain or generate such profiles are described in literature. For example, a detailed bottom-up stochastic model for electricity usage is proposed by Wilke et al. [96]. López-Rodríguez et al. [97] use a time-of-use survey to construct electricity consumption profiles for households, while a more general method to construct profiles for electricity and hot water usage is demonstrated by Wíden et al. [98, 99]. However, note that these are but a few possible approaches.

Here, the input data, i.e. the profiles for the electricity and heat demand, is generated using the Artificial Load Profile Generator (ALPG) presented in [71]. This open source profile generator uses a bottom-up modelling approach where the behaviour of individual inhabitants is simulated to obtain an occupancy profile. Resulting output of this generator was previously validated to accurately resemble real measurement data that was collected in a neighbourhood for a timespan of a year. The output of the ALPG results in a time series load profile for uncontrollable loads and vectors of constraints for devices that offer flexibility, such as e.g. start times (the moment the device is available) and end times (the deadline for the device to finish) for a washing machine. A control system can take these constraints on the usage of these devices as input to optimize their actual run times.

The first version of the ALPG only supported the generation of electricity profiles. Later its functionality has been extended with heat demand generation models. Based on this, the ALPG also produces a vector with thermostat setpoints to express the desired indoor temperature and a ventilation profile which is linked to the occupancy profile to ensure that enough fresh air is brought into the house. Finally, similar to the electricity consumption profile, also domestic hot tap water usage profiles are generated.

The information generated by the ALPG, together with weather data, now can be used as input for a thermal model of a household. In this study a model such as implemented in DEMKit (short for Decentralized Energy Management ToolKit), which is simulation and demonstration software developed at the University of Twente [20], is used. The household types used to generate the load profiles for the model of the greenfields neighbourhood ${ }^{2}$ are listed in Table 4.1. Furthermore, for the thermal simulation and calculation of PV production,

\footnotetext{
${ }^{2}$ The composition of household types is the real composition of household types in Markluiden (see Section 4.6)
} 
weather data from the KNMI [86] for 2013-2014 was used from weather station Twenthe.

Table 4.1: Households family type composition of the 16 houses

\begin{tabular}{cl}
\hline \# of houses & Household type \\
\hline 6 & Couple, dual worker \\
1 & Family, single worker \\
5 & Family, dual worker \\
1 & Single, retired \\
2 & Couple, retired \\
1 & Couple, single worker \\
\hline
\end{tabular}

\subsubsection{THE SIMULATOR}

To perform a simulation of the case-studies as presented in this chapter, DEMKit is used. DEMKit provides a library of device components (amongst others, electric vehicles and static loads), physical models (e.g. grid infrastructure) and control systems with optimization algorithms. Herein, DEMKit uses a bottomup cyber-physical systems approach where these components influence each other through their relations. As such, all components together form a (micro) grid whose behaviour can be simulated in detailed discrete time steps. DEMKit is the successor of the TRIANA simulator $[59,70]$ used previously.

To improve the accuracy of the simulation results for this study, new device components have been added. This concerns a realistic battery model based on models presented in [H:6], which can be used as replacement for the ideal battery model used in [H:1]. The battery optimization and control remains the same due to the standardized model interface [H:5]. From the thermal models, which are extensively evaluated in [29], two models were chosen to be implemented, a ${ }_{1} \mathrm{R} 1 \mathrm{C}$ model (one resistor, one capacitor) for conventional heating systems with radiators and a $2 \mathrm{R}_{2} \mathrm{C}$ model used for floor heating systems as found in modern and well insulated households. For these models, to each zone a heat source, such as a CHP or heat network, and a thermostat are coupled.

Compared to the approach used in the original paper [H:1], also the control and optimization techniques have received an update in DEMKit. Firstly, prediction modules for consumption, production and the expected flexibility that a device can offer based on historical data are added. These predictions are used as input for the optimization process, which is implemented by the profile steering algorithm [21] (see also Subsection 4.2.3). This profile steering approach is extended with an event-driven approach which allows to react on a deviation from the planning directly at the moment such a deviation occurs [61]. This way, a more realistic performance of the control system approach can be tested. Furthermore, an online control system based on double-sided auctions [91] is introduced, which uses the same structure of control as used with profile steering. 
In this set-up, the auction takes the planning as its input to select a clearing price which results in exactly the planned value (provided there is enough flexibility to do so). Due to the structure of the submitted bids, also production curtailment and load shedding are possible, meaning that also a flat, truly islanded microgrid can be simulated.

\subsubsection{COORdination MECHANiSMS}

To achieve a soft-islanded microgrid, it is important to coordinate the energy production, storage, and consumption between the various assets available within the microgrid. To achieve this, the profile steering algorithm is used to optimize the energy profile of the microgrid. The coordination structure consists of a hierarchical tree, in which the leaves are controllers representing a specific, individually modelled, device. All other (intermediate) nodes are formed by controllers running the profile steering algorithm to coordinate the energy profile of their respective children (which again may consist of nodes running the profile steering algorithm). This structure is depicted in Figure 4.3.

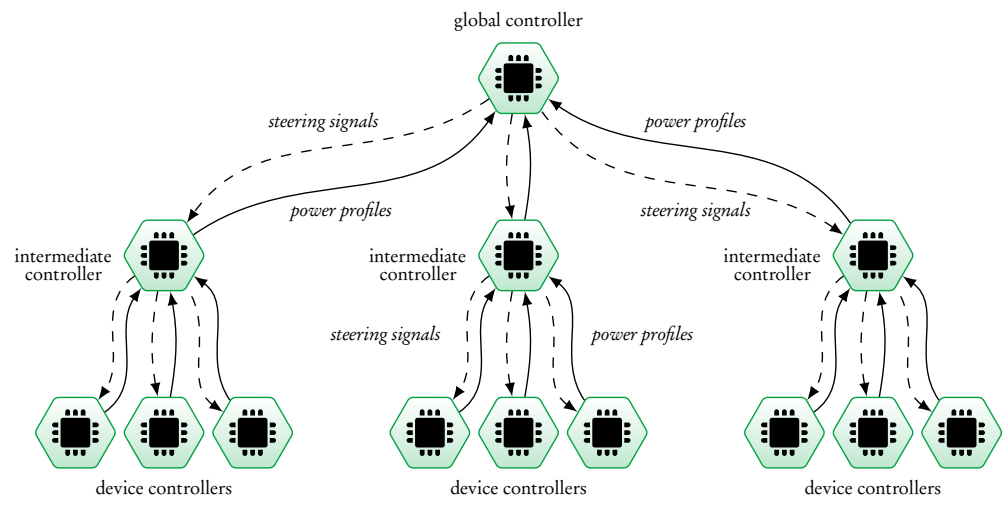

Figure 4.3: Hierarchical structure of higher level controllers running profile steering and device controllers as leaves.

Profile steering [21] is an optimization framework that works by means of a goal profile $\vec{p}$ which specifies the desired overall power consumption/production of the whole neighbourhood for a sequence of $N$ discrete time intervals in the future, i.e. $\vec{p}=\left[p_{1}, p_{2}, \ldots, p_{N}\right]^{T}$. In an iterative manner, the profile steering controller coordinates the overall power profile $\vec{x}=\left[x_{1}, x_{2}, \ldots, x_{N}\right]^{T}$ of the neighbourhood. This power profile is the aggregated profile of the set of all individual children at the node $M$, i.e. $\vec{x}=\sum_{m \in M} \overrightarrow{x_{m}}$. In each iteration, each child proposes a new power profile $\overrightarrow{x_{m}}=\left[x_{1}^{m}, x_{2}^{m}, \ldots, x_{N}^{m}\right]^{T}$, which expresses a potential power consumption/production vector for child $m$ to improve the objective at the parent. The desired objective is to minimize $\|\vec{x}-\vec{p}\|_{2}$. The profile steering approach works such that it iteratively selects the child of the 
given node that improves the objective most, resulting in updated profiles $\overrightarrow{x_{m}}$ and $\vec{x}$. This iterative process continues until no (significant) improvements are achieved.

The presented optimization framework has to rely on predictions (e.g. of solar production or local constraints) as it optimizes the energy profile for future intervals. These predictions are never accurate, possibly resulting for some devices in schedules which can not be executed due to changing circumstances. However, executing a new planning after each change in the given circumstances or the predictions is computationally too expensive. Therefore, two online control methods to resolve prediction errors are added.

The first is event-based profile steering [61], (PSE). This method utilizes the overall planning $\vec{x}$ created by the normal profile steering algorithm as a guideline. Additional vectors are introduced, which contain the most recent profiles of the connected children, denoted by $\overrightarrow{r_{m}}$, and the aggregated profile at the parent profile steering node $\vec{r}=\sum_{m \in M} \overrightarrow{r_{m}}$. Upon major events in the local (device) setting, the corresponding node $m$ sends a signal to its parent. These major events include e.g. weather forecast updates, a washing machine that becomes available, or upon detection that the existing planning becomes infeasible. The parent node responds to the signal of node $m$ with the predicted deviation of its current planning $\vec{x}$, i.e. $\vec{r}-\vec{x}$ is communicated back to $m$. Now node $m$ can update its current planning in a way that it minimizes $\|\vec{r}-\vec{x}\|_{2}$. Hereby $m$ replaces its old planning by its new planning. In this way node $m$ adapts its behaviour in a way that the neighbourhood profile stays as close as possible to the original planning. Since only one device needs to be (re-)planned at a time, no iterations are required. Furthermore, this approach is able to repair infeasible solutions using the same code-base as for the offline planning.

The second method to resolve prediction errors is to combine profile steering with a double-sided auction (PSA) [91]. The overall planning $\vec{x}$ as a result of the profile steering algorithm serves as a guideline in this method. The task of the double-sided auction is to realize for every time interval $n$ the planned power level $\vec{x}_{n}$ by performing an auction. For each auction, all devices construct a bid and communicate this bid to the auctioneer. A bid is a function that specifies the amount of power a device will consume/produce in a give time interval for each price in a given set of prices. Hereby, these bids only contain feasible options for the corresponding device and take into account local preferences. The auctioneer aggregates all received bids and subsequently selects a price for which the aggregated power consumption is closest to $\vec{x}_{n}$. This price is communicated to the devices, which in turn update their power consumption as specified by their bids. In contrast to the aforementioned event-based approach, the doublesided auction is able to control all devices in one auction round, but loses the ability to consider effects of the chosen actions on the energy usage in future time intervals.

The overall desired profile at the node used as objective in this work is the so- 
called zero-profile (i.e. $\vec{p}=[0, \ldots, 0]^{T}$ ), which indicates that energy should be kept locally as much as possible and that the profile of imported or exported energy $(\vec{x})$ should be flattened. Each planning spans 192 intervals of 15 minutes (i.e. 2 days) and a rolling horizon approach is used, in which a new planning is created every 96 intervals (i.e. every day). The simulations conducted in this work cover a complete year ( 365 days), where the discrete simulation time step (interval length) is set to 900 seconds ( 15 minutes).

\subsection{The LAYOUt OF THE NeIGHBOURHOOD}

The neighbourhood considered for this research (see Figure 4.4) can be considered as ideal in many respects. It consists of 16 houses arranged around a square. All houses are newly built and well insulated. The residents are assumed to be fully co-operative, they are willing to share data regarding their energy usage and behaviour and willing to share electricity, heat and flexibility among each other.

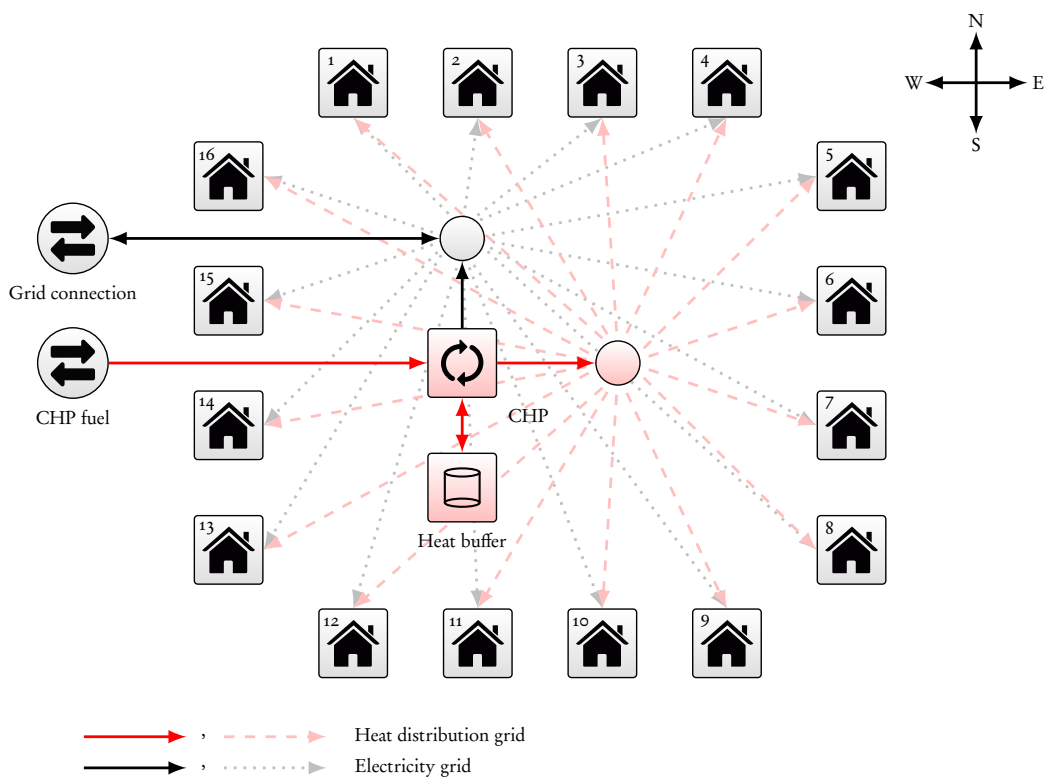

Figure 4.4: Schematic representation of the arrangement of the individual houses in the neighbourhood.

\subsubsection{Neighbourhood CHARActeristics}

All houses have a large section of windows at the back side of the house, facing the square and a smaller section of windows at the front side of the house, facing outward. So, based on this arrangement there are four types of houses to be considered, those facing North, East, South and West. For instance, houses 1,2,3 
and 4 are of type North. These houses have a large section of windows $\left(12 \mathrm{~m}^{2}\right)$ facing South, a smaller section of windows $\left(8 \mathrm{~m}^{2}\right)$ facing North and all the PVpanels are on the south side of the roof. The other house types have similar but slightly different characteristics, which are outlined in Table 4.2. There are also some facilities shared by the whole neighbourhood.

Table 4.2: Characteristics of the different house types.

\begin{tabular}{lllll}
\hline Type of house & North & East & South & West \\
\hline House \# & $1,2,3,4$ & $5,6,7,8$ & $9,10,11,12$ & $13,14,15,16$ \\
Front windows & $8 \mathrm{~m}^{2} \mathrm{~N}$ & $8 \mathrm{~m}^{2} \mathrm{E}$ & $8 \mathrm{~m}^{2} \mathrm{~S}$ & $8 \mathrm{~m}^{2} \mathrm{~W}$ \\
Back windows & $12 \mathrm{~m}^{2} \mathrm{~S}$ & $12 \mathrm{~m}^{2} \mathrm{~W}$ & $12 \mathrm{~m}^{2} \mathrm{~N}$ & $12 \mathrm{~m}^{2} \mathrm{E}$ \\
PV location & $\mathrm{S}$ & $\mathrm{E}$ & $\mathrm{S}$ & $\mathrm{W}$ \\
PV angle & $35^{\circ}$ & $35^{\circ}$ & $35^{\circ}$ & $35^{\circ}$ \\
PV efficiency & $16 \%$ & $16 \%$ & $16 \%$ & $16 \%$ \\
\hline
\end{tabular}

There is one common connection of the neighbourhood to the outside grid, which is used to import or export electricity if required. The neighbourhood shares a Combined Heat and Power generator (CHP). The CHP can be fuelled using various types of fuel, e.g. wood pellets, (bio)-gas or (bio)-oil, however, the type of fuel is not specified in this study. The CHP generates electricity which can be distributed to all houses and it also generates heat in the form of hot water which is also distributed to all houses by a local heat network. The CHP is connected to a $250 \mathrm{kWh}$ heat buffer, which effectively decouples the heat and electricity production by the CHP. If electricity is desired when there is no heat demand, the produced hot water is stored in the buffer. Conversely, if hot water is desired when there is no electricity demand, hot water can be discharged from the buffer to meet the demand.

The main goal for the CHP is to generate enough heat to meet all heat demand for the 16 houses at all times. The electricity generated by the CHP is only a by-product which is used to meet part of the electricity demand. The rest of the electricity demand is met by electricity produced by the PV-panels and by using the battery. In case of an electricity shortage, input from the grid is used as a last resort.

Figure 4.5 gives a schematic representation of the composition of the individual houses. The square icons represent the devices and energy demands. Each house has a heat demand consisting of both space heating and tap water and it also has fixed and flexible loads. Fixed loads are devices that are switched on at a time that is convenient for the user, e.g a lamp or coffee maker. Flexible loads are devices that can be switched on or off at specific times, as long as their function fulfils the requirements of the users (e.g. a washing machine or a dishwasher should be finished at the time specified by the user). Furthermore, each house contains a battery for storage of electrical energy, and a set of PV-panels to generate electrical energy. 


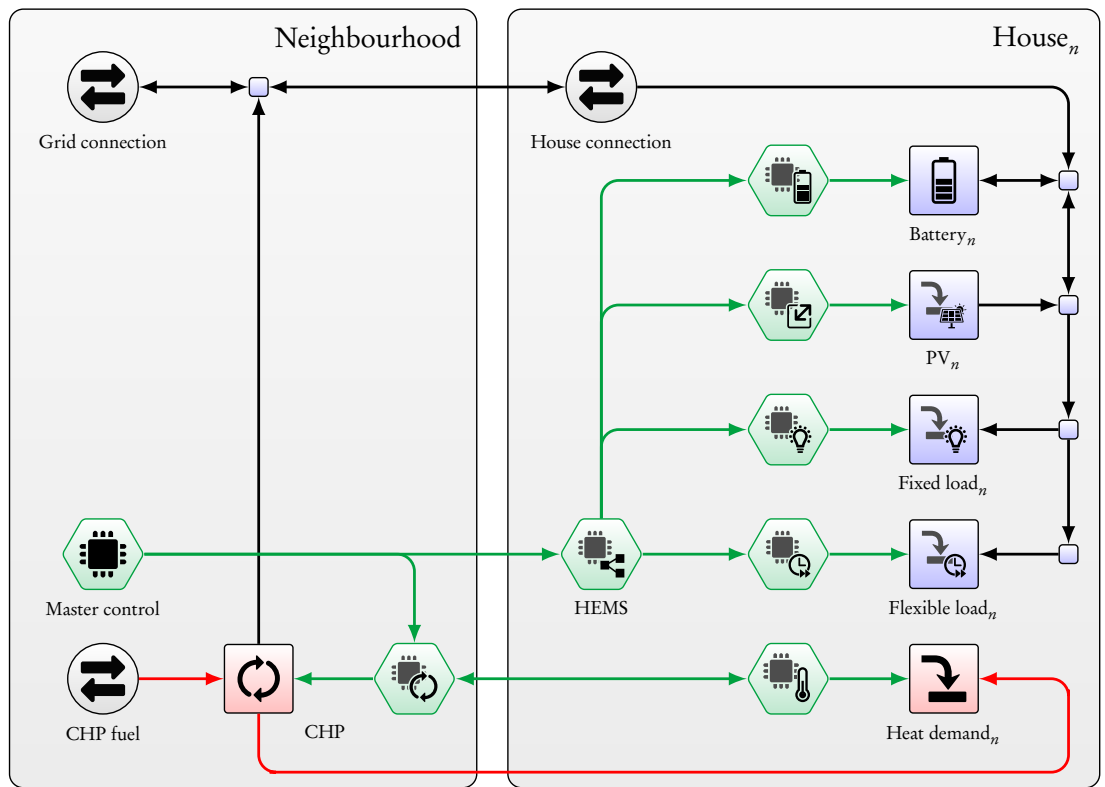

Figure 4.5: Schematic representation of an individual house and its connection to the central CHP and control system. The physical part of the model is represented by square icons (devices) and circular icons (grid infrastructure). The cyber part is shown using hexagonal icons that represent (embedded) computers that run the control algorithms. The links between these icons depict the relation between two or more objects.

The hexagonal icons in Figure 4.5 represent (embedded) computers that run the control algorithms. For instance a battery controller is used to control the battery, meaning that the state of charge (SoC) is monitored and that commands are given on how much energy should be stored in the battery or be discharged from the battery. A time-shiftable controller is used to control flexible devices, for which it is possible to control the start of the operation of such a device within given limits. All controllers in a house are in turn controlled by the bome energy management system (HEMS). The HEMS also accepts (overriding) input from the residents. Lastly, the master controller controls the HEMS's in the neighbourhood as well as the central CHP to make sure that all energy demands are met in such a way that a minimal amount of energy is imported from the grid.

\subsubsection{Proper SIZE OF RELEVANT EQUiPMENT}

As shown in Figure 4.5, each house in the greenfields neighbourhood has PVpanels and a battery, and shares a CHP with the other houses. However, the proper size of these components has yet to be determined. In the previous 
research [H:1] it was concluded that using $15 \mathrm{~m}^{2} \mathrm{PV}$-panels and a $2 \mathrm{kWh}$ battery per house, and a $60 \mathrm{~kW}$ thermal / $30 \mathrm{~kW}$ electric CHP with a $250 \mathrm{kWh}$ buffer, might be enough to achieve soft-islanding. However, a preliminary simulation of the greenfields neighbourhood with the extended models, using these parameters did not support this result. There are several days in the year, during which there is still a significant power demand needed from the grid. Therefore, in a first step new specifications for the equipment are determined with which the neighbourhood can achieve soft-islanding.

To determine these sizes of equipment in the given neighbourhood, simulations are used. More specifically, a complete model of the neighbourhood, consisting of individually modelled devices and controllers as presented in the previous subsection is integrated in DEMKit. Several sets of simulations are executed, whereby in each set a specific parameter is changed, such as the capacity of batteries or the size of a PV setup. Within the simulations, the PSE energy optimization method (presented in Subsection 4.2.3) is used, including predictions. The resulting DoA of the simulations are used to select a proper size of the equipment.

The advantage of this method is that during the sizing step the same control is used, such that it accurately represents the final energy profile, and thus DoA, of the considered soft-islanded community. The drawback is that this method is time consuming due to the vast amount of detailed simulations that need to be executed. Note that simply scaling the achieved results is not an option as different sizes of equipment often result in a different use of flexibility. This is the result of the complex interaction with other equipment and the presence of uncertainty.

\subsubsection{RECONSIDERING THE BATTERY SIZE}

In [H:1], the size of the home batteries was determined based on already given specifications for all of the other devices. Hereby the capacity was chosen as the smallest capacity necessary for achieving soft-islanding. Therefore a logical first step is to analyse whether or not simply increasing the battery size is enough to achieve soft-islanding with the new setting. To determine the appropriate battery size three specific weeks were analysed in detail:

- week $A$, a week during which the highest PV-production in the year is achieved (in May).

- week $B$, a week during which there is low PV-production as well as a low heat demand (in October).

- week $C$, a week during which the highest heat demand of the year is achieved (in November).

The characteristics of these weeks are listed in Table 4.3. 
Table 4.3: Description of the test weeks.

\begin{tabular}{llllll}
\hline Week & Date & \multicolumn{2}{l}{ PV generation } & \multicolumn{2}{l}{ Heat demand } \\
\hline A & 7-15 May. & highest & $(194 \mathrm{kWh} / \mathrm{panel})$ & low & $(678 \mathrm{MWh})$ \\
$\mathrm{B}$ & $2-9$ Oct. & low & $(70 \mathrm{kWh} /$ panel $)$ & low & $(706 \mathrm{MWh})$ \\
C & 27 Nov. - 3 Dec. & low & $(20 \mathrm{kWh} /$ panel $)$ & highest & $(7853 \mathrm{MWh})$ \\
\hline
\end{tabular}

In week $A$ there is a high generation of electricity by the PV-panels, and a low heat demand. In Figure 4.6a the grid power demand for the whole neighbourhood in week A is shown (negative demand being exported) for different sizes of the house battery between $2 \mathrm{kWh}$ and $6 \mathrm{kWh}$. For clarity, the values of the largest electricity import and export in week A and B are presented in Table C. 1 in Appendix C. Figure 4.6b shows the corresponding combined SoC of the batteries. In case of the smallest battery capacity $(2 \mathrm{kWh})$, the electricity generated by the $\mathrm{CHP}$ and the PV-panels is more than sufficient to meet the daytime demands as well as charging the battery completely (see Figure 4.6b). In the evening when there is no generation from the PV-panels, however, the electricity generated from the CHP and the electricity discharged from the batteries is sometimes insufficient to meet the demands. However, if the battery capacity is large enough also the electricity demands in the evening can be met easily. From the figure it is clear that a battery size of $5 \mathrm{kWh}$ is sufficient.

In week $B$ there is little generation of electricity by the PV-panels and a low heat demand. Figure $4.6 \mathrm{c}$ shows that the electricity generated by the CHP and the PVpanels combined with a $2 \mathrm{kWh}$ battery is only sufficient to meet the electricity demands during the day. In this case even increasing the battery capacity to 6 $\mathrm{kWh}$, which is 3 times the original capacity, does not solve all the problems. On the days where the least electricity is generated by the PV-panels (most notably day 6) the battery can not be fully utilized (see Figure 4.6d). However, on the days where the most electricity is generated by the PV-panels on average $15 \mathrm{~kW}$ is delivered back to the grid.

To get more insight in the exchange with the grid, Figure 4.7 gives the amount of electricity imported from the grid for the different battery capacities and the two weeks A and B. For week A, the imported electricity is $\leq 0.5 \mathrm{kWh}$ for all battery capacities. However, note that for some battery capacities (4 and $5 \mathrm{kWh}$ ) the electricity import is larger than expected, based on the imports achieved with smaller batteries. These differences in electricity imports are likely caused by randomness in the simulation, e.g. a fixed load is activated randomly while a flexible load was already activated. Hence, in this particular week the battery capacity has less influence on the electricity imported from the grid, than other factors. For Week B, it is observed that the import decreases with increased battery size, however, with each increase in battery size there is a smaller decrease in electricity imported from the grid. Hence, at some point the decrease of electricity imported from the grid does no longer justify the costs 


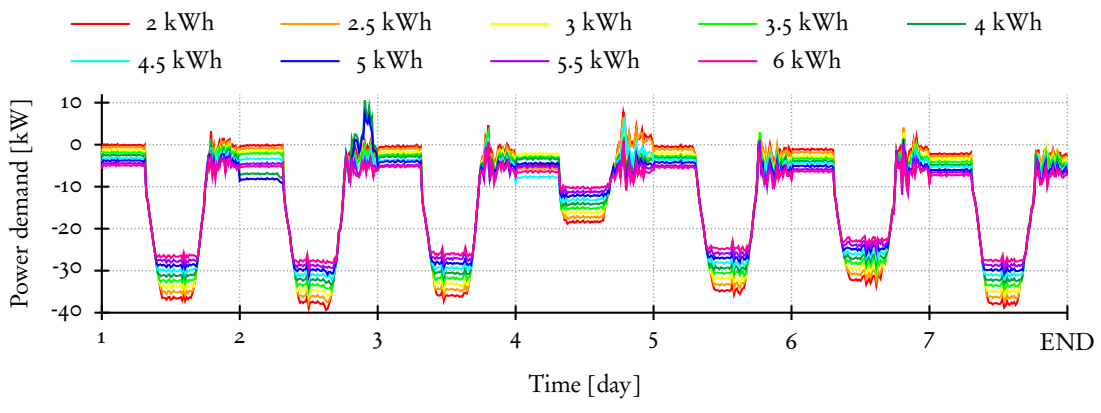

(a) Week A: Total grid power demand

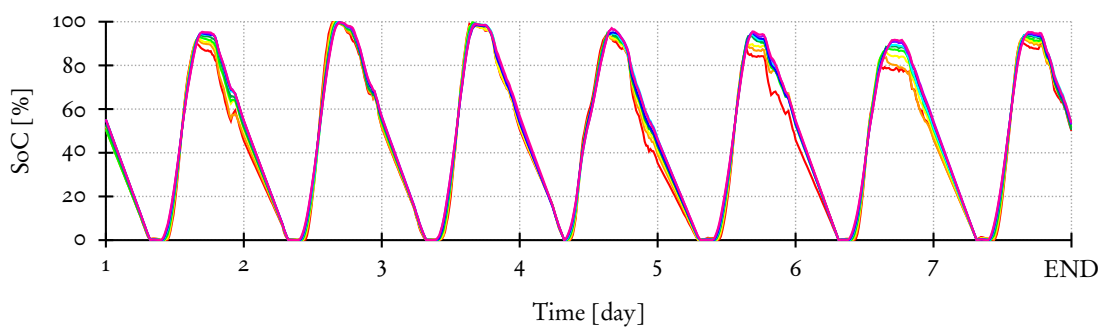

(b) Week A: Combined SoC

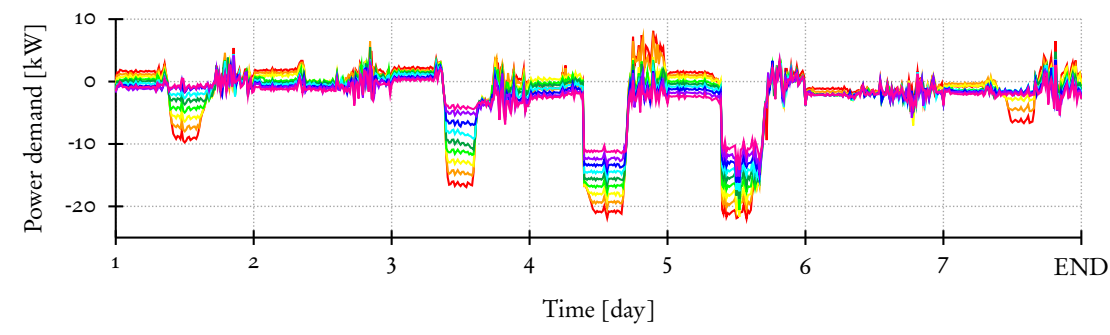

(c) Week B: Total grid power demand

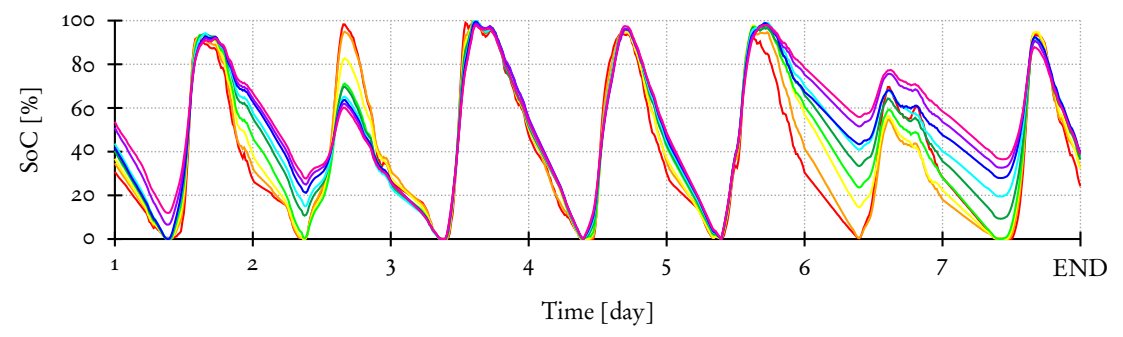

(d) Week B: Combined SoC

Figure 4.6: Simulation of the total grid power demand and combined battery state of charge for several battery capacity in the test weeks A and B. Note that the grid power demand is displayed, so a negative power demand is power supplied back to the grid. 
of the extra battery capacity. So in this case increasing the battery capacity will yield marginal improvements, unless an unjustifiably large battery is used.

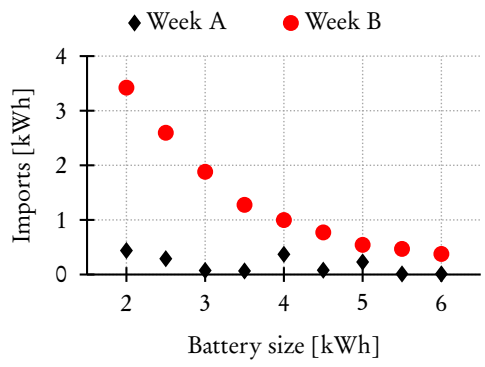

Figure 4.7: Total amount of electricity imported from the grid in test weeks A and $\mathrm{B}$ for different battery sizes.

In week $C$, the electricity generated by the CHP is more than sufficient to meet the electricity demands regardless of the amount of electricity produced by the PV-panels or the capacity of the battery.

\subsection{SimultaneOUs Sizing OF THE BATTERy, PV-PANELS AND CHP.}

The results of Subsection $4 \cdot 3 \cdot 3$ show that to decrease the import from the grid to almost $\circ \mathrm{kW}$ by increasing the battery capacity, is only an option in week $A$. In week $B$ even an increase of the battery capacity by a factor of 3 would only have a limited positive effect and still a positive grid power demand remains. In week $C$ the grid power demand is already zero regardless of the battery size. However, the battery is not the only device which can be optimized to decrease the grid power demand to zero. The area of PV-panels per house, and the heat / electricity production ratio of the CHP can also be optimized. Therefore for these two parameters a parameter-sweep was performed. In Figure 4.8 the average daily grid energy demand per house in week $\mathrm{B}$, as a function of the PVpanel area for five battery capacities and three different CHP heat to electricity production ratios is displayed.

The trend in all three figures is that the maximum grid power demand is decreasing with an increase in PV-panel area. In all three figures the maximum grid power demand is also smallest for the largest battery size. Increasing the battery capacity from $2 \mathrm{kWh}$ to $3 \mathrm{kWh}$ or from $3 \mathrm{kWh}$ to $4 \mathrm{kWh}$ results on average in a $0.5 \mathrm{kWh}$ decrease of the average daily grid energy demand per house. A further increase of the battery capacity results only in a limited decrease in grid power demand. Lastly, the average daily grid energy demand per house is smallest for the smallest CHP heat to electricity production ratio 1.75 (Figure $4.8 \mathrm{a}$ ), however, the $\mathrm{CHP}$ heat to electricity production ratio has a very limited influence on the average energy demand per house. 
The average daily grid energy demand per house in week $A$ is always below 0.5 $\mathrm{kWh}$. Moreover increasing the PV-panel area or the battery capacity, or changing the CHP heat to electricity production ratio yields only small improvements. The average daily grid energy demand per house for test week $\mathrm{C}$ is always below $\circ \mathrm{kWh}$, regardless of the CHP heat to electricity production ratio, PV-panel area or battery capacity. So the parameter sweep analysis of weeks $A$ and $C$ had no influence on the equipment sizing choices.

In conclusion, the power demanded from the grid can be decreased by increasing the battery capacity. However, the further the battery capacity is increased, the lower is the additional decrease of the power demand from the grid (see Figure 4.7). Hence, if only the battery capacity is considered to achieve a decrease of the grid power demand in week B (low PV production and low heat demand), even a capacity of $6 \mathrm{kWh}$ per house is not enough to decrease the power demand from the grid to zero. Moreover the increased battery capacity is only needed for a few days each year, while the rest of the year it would remain unused. So this would not be a very cost effective solution. A better solution is to choose a good combination of battery capacity, PV-panel area and CHP heat to electricity production ratio. Such a combination is presented in Table 4.4.

Table 4.4: Equipment size and configuration.

\begin{tabular}{ll}
\hline Equipment & Size and configuration \\
\hline CHP unit & $60 \mathrm{~kW}_{\text {th }} / 30 \mathrm{~kW}_{\mathrm{el}}$ \\
CHP buffer & $250 \mathrm{kWh}$ \\
Battery & $4 \mathrm{kWh} /$ house \\
PV-panels & $22.4 \mathrm{~m}^{2} /$ house $(16 \%$ eff. $)$ \\
\hline
\end{tabular}

In relation to previous work [H:1] the $\mathrm{CHP}$ heat to electricity production ratio is kept the same (at 2.0), the battery capacity is increased to $4 \mathrm{kWh}$ and the

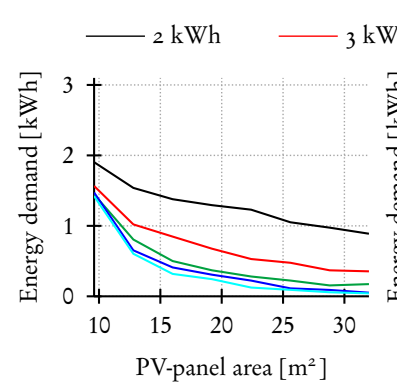

(a) $\mathrm{CHP} \mathrm{h/e}=1.75$

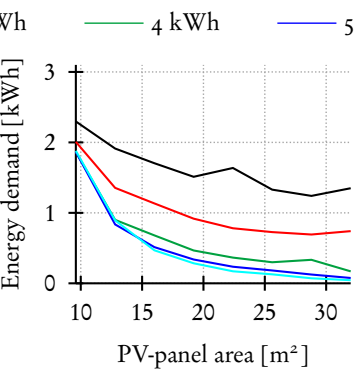

(b) $\mathrm{CHP} \mathrm{h/e}=2.0$

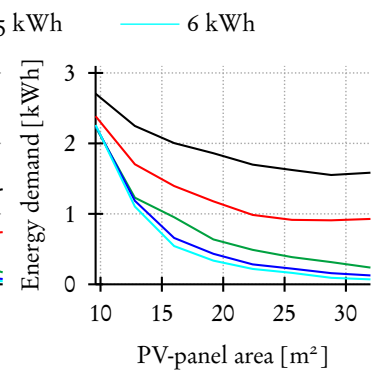

(c) $\mathrm{CHP} \mathrm{h} / \mathrm{e}=2.25$

Figure 4.8: Average daily grid energy demand per house for the test week B as function of PV-panel area for several battery sizes and CHP heat / electricity production ratios. 
PV-panel area is increased to $22.4 \mathrm{~m}^{2}$ (14 PV-panels of $1.6 \mathrm{~m}^{2}, 16 \%$ efficiency). In this case the average daily energy demand from the grid per house in the tested weeks is decreased from $1.5 \mathrm{kWh}$ to $0.3 \mathrm{kWh}$, which is a $80 \%$ reduction.

\subsection{Results \& Discussion}

In this Section, the results of yearly simulations of the microgrid for different control mechanisms and some variants of the considered microgrid are evaluated. Two uncontrolled scenarios, called $N B$ (without batteries) and $N C$ (with batteries) are considered. In these scenarios the different devices have only a local control and do not consider interaction with other devices in their environment. Additionally, the two controlled cases (PSE and PSA, defined in Section 4.2.3) both with batteries included are simulated. Furthermore, a variant of the ideal microgrid which uses the DiBu-model (see Chapter 2) in stead of an ideal battery model is evaluated. This leads to a variation of the PSE scenario (called PSE-B) in which the ideal battery model is replaced by the DiBu-model.

\subsubsection{YeARLY RESUlTS}

Over the whole year, the average annual electricity demand of a household within the microgrid is $3033 \mathrm{kWh}$, of which $2676 \mathrm{kWh}$ is static load and 357 $\mathrm{kWh}$ is consumed by flexible whitegood appliances. The yearly production per household is $8109 \mathrm{kWh}$, of which the PV-panels produce on average $3745 \mathrm{kWh}$ per household and the CHP produces $4364 \mathrm{kWh}$ of electricity per household on an annual basis. The average household heat demand is $8728 \mathrm{kWh}$. Note, that these figures correspond approximately to the average yearly energy usage for a 2 person household in the Netherlands, $2950 \mathrm{kWh}$ electricity and $1020 \mathrm{~m}^{3}$ gas $(\sim 10200 \mathrm{kWh})[14]$.

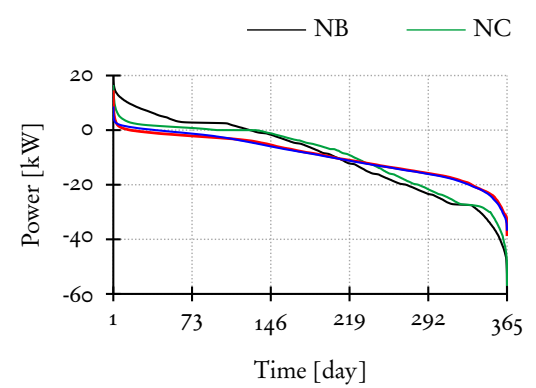

(a) Full load duration curve

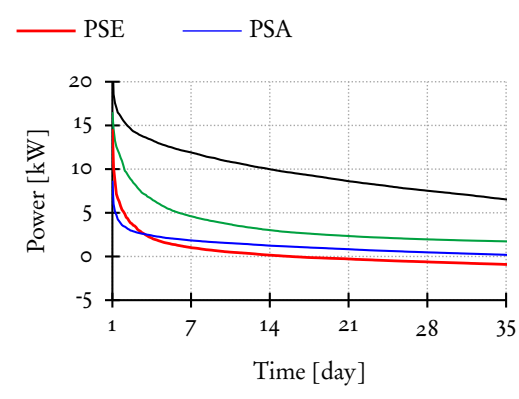

(b) Zoomed load duration curve

Figure 4.9: Load duration curves of the power demand of the entire microgrid.

In Figure 4.9, the load duration curves of the power import/export of the considered microgrid are shown for the four scenarios. As one would expect, the 
$N B$ case performs worst in terms of autarky, as it has to import, both, the most energy but also the highest peak powers. Adding a battery, with a very simplistic and greedy controller already shows a significant improvement where the peak power of the complete microgrid is reduced from $24.0 \mathrm{~kW}$ to $16.5 \mathrm{~kW}$. Both control cases (PSE and PSA) result in significant improvements, where the more direct method of control PSA allows to reduce the peak power almost completely. On the other hand, PSE is able to use the flexibility better to optimize towards autarky, because of its model predictive nature (see Figure $4.9 \mathrm{~b}$ ). With PSE, only for $4.3 \%$ of the time electricity is imported from the main grid, followed by PSA with $10.7 \%$. The $N C$ case has a deficit for significantly more intervals $(31.0 \%)$ and without batteries $(N B)$ the results are even worse (34.7\%). As expected, without batteries, the DoA (as defined in Section 4.1) is rather low with $69.7 \%$ for the $N B$ case (see Table 4.5). When introducing batteries, the DoA significantly increases to $93.2 \%(N C)$. By adding control, a close to $100 \%$ autarky can be reached, as shown in Table 4.5 .

Table 4.5: Statistics of the full year, all values represent the average per household

\begin{tabular}{rccccccc}
\hline & Import & Export & DoA & \multicolumn{3}{c}{ Share in electricity supply [\%] } \\
& {$[\mathrm{kWh}]$} & {$[\mathrm{kWh}]$} & {$[\%]$} & Grid & PV & CHP & BAT \\
\hline NB & 918.2 & 5993.3 & 69.7 & 30.3 & 28.9 & 40.8 & 0.0 \\
NC & 270.8 & 5346.4 & 93.2 & 6.8 & 43.1 & 30.6 & 19.5 \\
PSE & 36.5 & 5111.0 & 99.1 & 0.9 & 41.9 & 42.2 & 15.0 \\
PSA & 66.0 & 5138.4 & 98.4 & 1.6 & 41.6 & 40.9 & 15.9 \\
PSE-B & 61.7 & 5127.4 & 98.4 & 1.6 & 40.6 & 44.2 & 13.6 \\
\hline
\end{tabular}

Table 4.6: Battery statistics of the full year, all values represent the average per household

\begin{tabular}{rccccc}
\hline & Self-consumption & Buffered & \multicolumn{3}{c}{ Origin of energy [\%] } \\
& {$[\%]$} & {$[\mathrm{kWh}]$} & Grid & PV & CHP \\
\hline NB & 26.09 & 0.0 & 0.0 & 0.0 & 0.0 \\
NC & 40.88 & 933.6 & 0.0 & 92.1 & 7.9 \\
PSE & 43.66 & 963.9 & 0.0 & 87.7 & 12.3 \\
PSA & 43.39 & 970.8 & 0.0 & 88.3 & 11.6 \\
PSE-B & 42.86 & 874.7 & 0.0 & 86.2 & 13.8 \\
\hline
\end{tabular}

Table 4.5 also provides information about the origin of the consumed energy. Without batteries, most energy that is locally produced comes from the CHP, which can be explained by the fact that heat demand, and therefore electricity production, is linked strongly to human activity. In the $N C$ case, the batteries are controlled based on the energy balance within the house, which results in a 
much higher usage of (stored) solar energy. With the control system, the share between CHP and PV energy is close to a fifty-fifty division. More notably, by better matching demand and supply, the PSE controlled case is able to achieve a high DoA of $99.1 \%$ by using more energy directly from the PV-panels and CHP. This results in a lower usage, and thus wearing, of the batteries. To get more insight into the usage of the batteries, in Table 4.6 information is presented on the self consumption of locally produced electricity, on the amount of buffered energy and the origin of the buffered energy. The results show that the batteries are mainly used to store electricity produced by $\mathrm{PV}$, as the electricity production by the CHP can be matched with the demand more easily through the large heat buffer and the simultaneous demand for heat and electricity.

\subsubsection{SPECIFIC WEEKS}

As seasonal effects play a role in the performance of a microgrid, in this subsection some of the data also considered in the previous subsection, is analysed. However, this time the data is presented for the specific weeks A, B and C in Figure 4.10 (more details are provided in Table 4.7). In the coldest week, week $\mathrm{C}$, the CHP has to run often to fulfil the heat demand. In terms of electricity, it thereby produces more than enough energy throughout the day, such that even in the uncontrolled case, without batteries, almost a $100 \%$ DoA is reached. In the other two weeks, where the production of PV is more dominant, it is observed that the DoA significantly drops for $N B$ as it cannot store the electricity generated from $\mathrm{PV}$ to balance the energy mix. As a result, during the week with the least energy production, the DoA drops to only $48.2 \%$. Both PSE and PSA are able to maintain a high DoA. However, the full model predictive approach within $P S E$ is clearly better able to keep on matching supply and demand in week $\mathrm{B}$, still resulting in a $97.2 \%$ DoA during this challenging week. In the controlled cases, the battery is almost exclusively used to store electricity from PV in both weeks $\mathrm{A}$ and $\mathrm{B}$.

\subsubsection{Planning versus realization}

Profile steering makes use of model predictive control to optimize the energy usage of connected devices. It does so by creating a planning for each device (which then is aggregated for each house) in an online fashion. As such, the accuracy of a planning depends on the accuracy of the predictions and therefore also affects the DoA. Furthermore, online control is applied to resolve prediction and planning errors to ensure that control actions are feasible for the attached devices. The online-control method results in the actual profile (realization). In this section the the planning and the realization are compared to get a better understanding of the differences between the two.

For the PSE case, the annually imported energy per house in the planning was $28.3 \mathrm{kWh}$ with energy import for $4.0 \%$ of the time, whereas in the realization this is $36.5 \mathrm{kWh}$. The results of the simulations show that the planned DoA is 


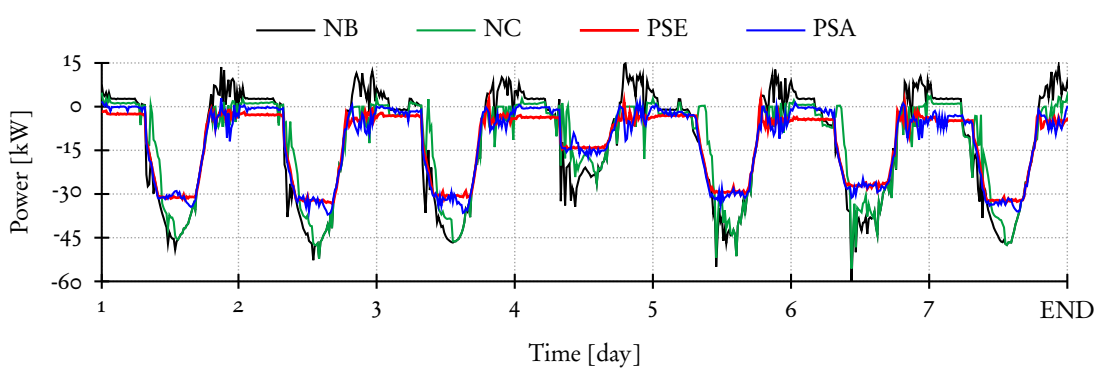

(a) Week A

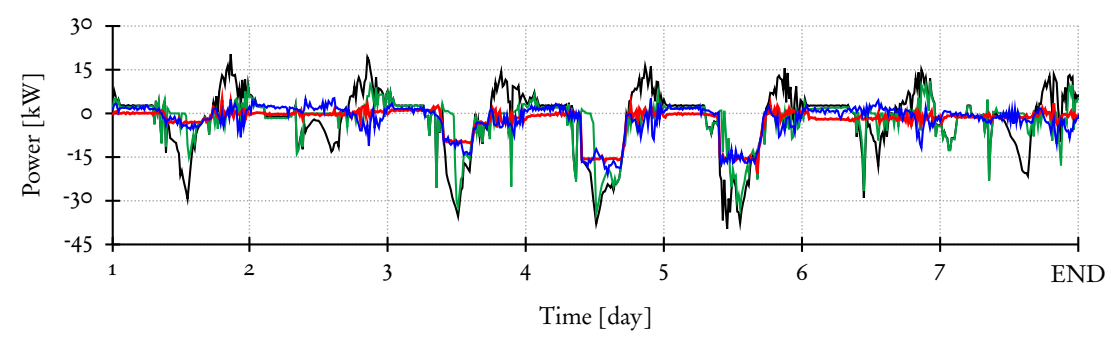

(b) Week B

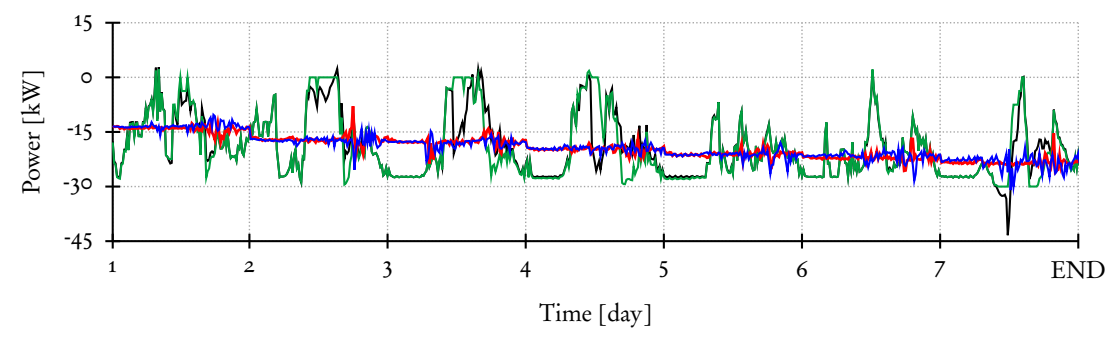

(c) Week C

Figure 4.10: Simulation results of the total grid power demand for the microgrid in weeks A, B and C. 
Table 4.7: Statistics of specific weeks, all values represent the average per household

\begin{tabular}{|c|c|c|c|c|c|c|c|}
\hline & \multirow{2}{*}{$\begin{array}{l}\text { Import } \\
{[\mathrm{kWh}]}\end{array}$} & \multirow{2}{*}{$\begin{array}{l}\text { Export } \\
{[\mathrm{kWh}]}\end{array}$} & \multirow{2}{*}{$\begin{array}{c}\text { DoA } \\
{[\%]}\end{array}$} & \multicolumn{4}{|c|}{ Share in electricity supply [\%] } \\
\hline & & & & Grid & PV & CHP & BAT \\
\hline \multicolumn{8}{|l|}{ Week A } \\
\hline NB & 20.48 & 154.43 & 63.92 & 36.08 & 47.88 & 16.04 & 0.00 \\
\hline NC & $3 \cdot 32$ & 137.11 & 95.89 & 4.11 & 59.07 & 11.56 & 25.26 \\
\hline PSE & 0.12 & 135.21 & 99.86 & 0.14 & 64.52 & 16.84 & 18.50 \\
\hline PSA & 0.27 & 133.95 & 99.68 & 0.32 & 63.55 & 14.79 & 21.34 \\
\hline \multicolumn{8}{|l|}{ Week B } \\
\hline NB & 30.77 & 54.17 & 48.21 & 51.79 & 26.93 & 21.28 & 0.00 \\
\hline NC & 11.63 & 35.07 & 85.93 & 14.07 & 45.85 & 14.41 & 25.67 \\
\hline PSE & 2.32 & 26.15 & 97.17 & 2.83 & 48.37 & 24.17 & 24.64 \\
\hline PSA & 8.10 & 30.52 & 90.39 & 9.61 & 46.59 & 20.59 & 23.21 \\
\hline \multicolumn{8}{|l|}{ Week C } \\
\hline NB & 0.26 & 201.80 & 99.57 & 0.43 & 7.95 & 91.62 & 0.00 \\
\hline NC & 0.16 & 201.91 & 99.77 & 0.23 & 17.16 & 78.65 & 3.96 \\
\hline PSE & 0.00 & 203.07 & 100.00 & 0.00 & $5 \cdot 34$ & 91.52 & 3.13 \\
\hline PSA & 0.00 & 202.64 & 100.00 & 0.00 & 5.71 & 90.27 & 4.02 \\
\hline
\end{tabular}

slightly better, with $99.3 \%$ compared to the $99.1 \%$ obtained for the realization. For the $P S A$ case, the prediction remarkably overestimates the average energy that each house needs to import, at $94.1 \mathrm{kWh}$ compared to the actual $66.0 \mathrm{kWh}$. Furthermore it is estimated that the house needs to import electricity for $17.8 \%$ of the time. The planned DoA is also worse with $97.6 \%$ compared to the $98.4 \%$ obtained for the realization. The difference between the planning and the realization is caused by the fact that the control with the double-sided auction (PSA) results in different priorities for different devices compared to that of the profile steering based (PSE) planning. Therefore, flexibility is used in a different way. As an example of this, the resulting power profiles of various equipment in week $\mathrm{B}$, for both planning strategies, are presented in Figure 4.11.

As the baseload electricity demand and the electricity production from the PVpanels are uncontrollable, the realized power profiles for the PV-panels and the baseload are the same for both PSE and SPA planning strategies. The realized power profile for the CHP is very similar for both planning strategies. This is to be expected, because the CHP is mainly used to meet the heat-demand, which is the same for both planning strategies. Hence, regardless of the planning strategy the CHP must be operated in such a way that the heat demand is met.

Oppositely, the realized power profiles for the whitegoods, the CHP and the battery are quite different. Using the PSE planning strategy (Figure 4.11a) the whitegoods are activated during the whole day, in a way that devices are not active simultaneously. The battery is charged when electricity is produced by 


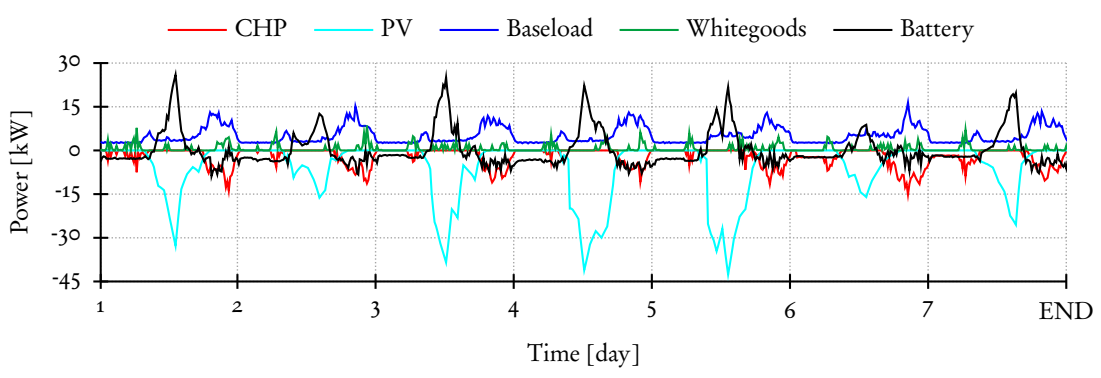

(a) PSE

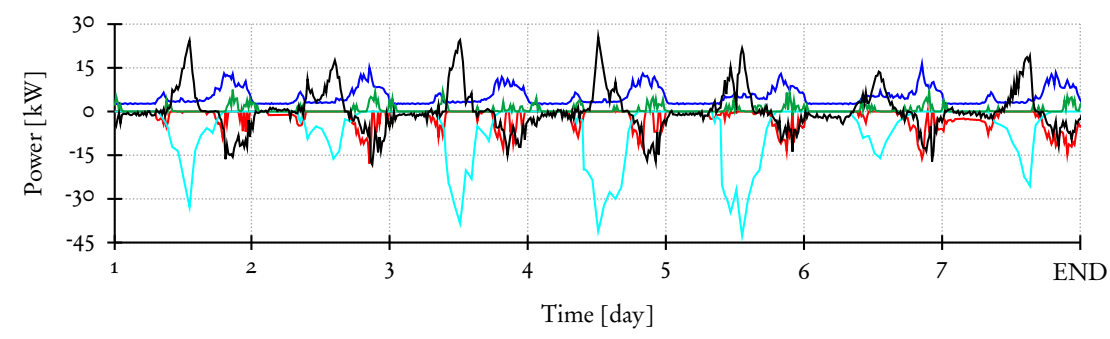

(b) PSA

Figure 4.11: Comparison of the aggregated electricity consumption and production of various devices in Week B for PSE and PSA.

the PV-panels, and discharged when no electricity is produced. There are almost no instances where the battery is idle. The PSA planning strategy (Figure 4.11b) results in different power profiles. The whitegoods are activated mostly when the $\mathrm{CHP}$ is active, so more devices are active simultaneously. The battery is charged when electricity is produced by the PV-panels. The battery is discharged when the whitegood devices are active and idle for longer periods between charging and discharging. This all results in different DoA's for both planning strategies.

\subsubsection{The DiBu-MODEL}

In a real situation the given battery technologies may have problems to provide the relative high power output used within the ideal battery model. For this, another PSE simulation was done using the realistic DiBu battery model from [H:6] indicated with PSE-B. Herein, the parameters for a Lead-acid battery obtained in previous work [H:5] were used and up-scaled to match the $4 \mathrm{kWh}$ battery of the model. As a result, the maximum power rating of $3.7 \mathrm{~kW}$ (both charging and discharging) had to be reduced to a maximum of $1.8 \mathrm{~kW}$ for discharging and a maximum of $0.9 \mathrm{~kW}$ for charging. The results of this simulation are presented in Tables 4.5, 4.6 and 4.7, and shown in Figure 4.12. Due to the significant lower maximum charging power, the battery is not able to absorb as 
much solar energy as observed in the ideal PSE case, resulting in a drop of the DoA from $99.1 \%$ to $98.4 \%$. This decrease is most dominant in the challenging week $B$ where the DoA drops from $99.9 \%$ to $97.2 \%$. Overall, the results show that profile steering usually does not result in high peak discharge and charge powers, such that the realistic battery can closely follow the original planning. The production, consumption and flexibility profiles (Figure 4.10) also show relative high production and lower consumption power profiles, which is complementary to the (asymmetrical) higher charge power for the realistic battery. Hence, the lower discharge power of the DiBu-model does not lead to problems for the considered household power profiles.

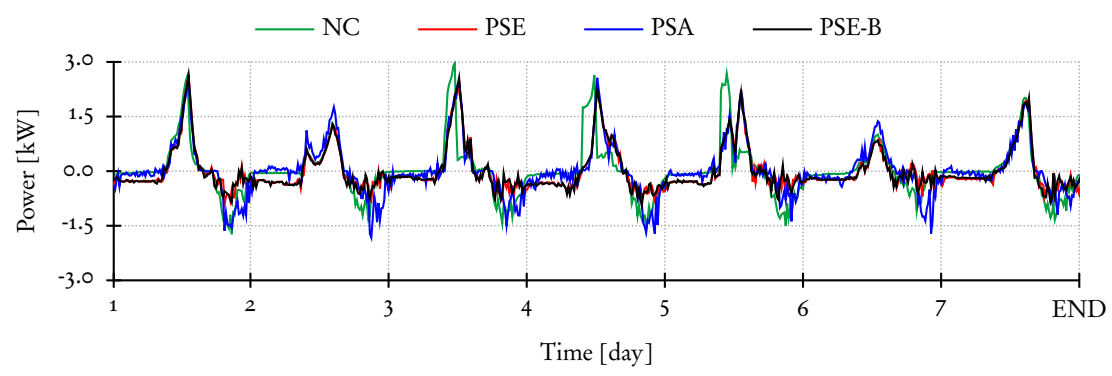

(a) Power

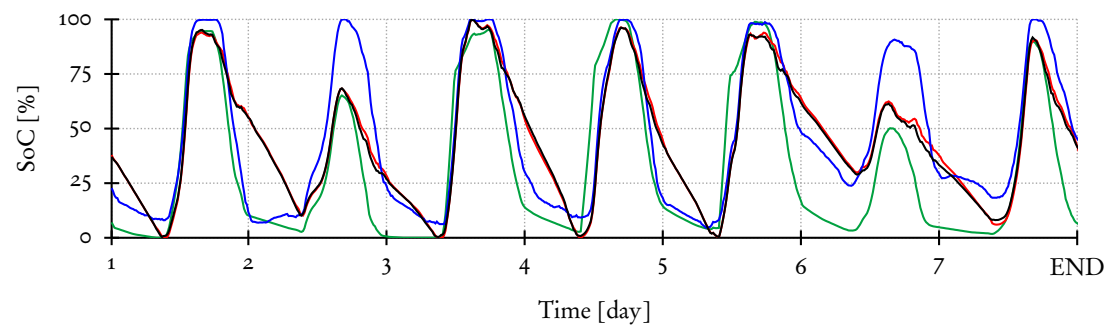

(b) SoC

Figure 4.12: Battery discharge, charge and state of charge in various simulations for week B. Aggregated data of all batteries.

\subsubsection{IN CONCLUSION}

In conclusion, the results of the sizing and simulations indicate that either substantial battery storage or overproduction from renewable sources is required to achieve an (nearly) autarkic operating microgrid. The over-all best results are gained in the PSE case, where batteries are placed in each house and profile steering is applied, with a DoA of $99.1 \%$. Electricity imports from the grid are limited to only $36.5 \mathrm{kWh} /$ year. However, $5.1 \mathrm{MWh} /$ year is still exported to the grid. The results over a whole year indicate that in all cases the PV installations 
are "overdimensioned" in the sense that less than half of all locally generated energy is consumed locally. Hereby, again the PSE case performs best at $43.7 \%$.

From the results of the PSE-B case, it is concluded that the application of the DiBu-model yields a $1.8 \%$ lower self-consumption, $9.3 \%$ less electricity buffered, a $0.7 \%$ lower DoA and a $40.8 \%$ higher electricity import from the grid. But overall, the observations show that profile steering in general does not result in high discharge peaks and high charge powers, such that the realistic battery can closely follow the original planning. Moreover, the PSE-B case yields more realistic results, and answers the question what DoA can be reached for a given battery capacity more accurately.

Generally it is concluded that complete islanding of the neighbourhood would be very costly. On the one hand, to reduce the electricity imports an unrealistic amount of electrical energy storage has to be installed, most of which will only be used a few hours per year. On the other hand, to reduce the electricity exports, the CHP should produce less electricity, which would mean that heat-demands would not be met at all times, leading to a loss of comfort, which is not acceptable. Therefore, soft-islanding would be a better solution as it leads only to an average daily import of $0.1 \mathrm{kWh}$ per house, which can be considered as a marginal load for the grid. The huge amounts of overproduction may potentially stress the grid, but this can be solved if needed by performing curtailment. 


\subsection{Case study: The neighbourhood of Markluiden}

Although the concepts and methods discussed in the previous sections work well in simulations, and provide interesting and useful results, the practical application remains untested. Therefore, in this section the process applied in the previous sections, is repeated to study an existing neighbourhood of 16 houses in Markluiden in the Netherlands. The goal is to determine if a multi-energy systems applied to the existing households in Markluiden could be operated in a "soft-islanded" manner. This case study largely follows the steps taken for the analysis of the "greenfield" neighbourhood. Characteristics of the Markluiden neighbourhood, together with reasons why this location is potentially suitable for soft-islanding operation, are discussed in Section 4.6.1. The process to size the various components within the hybrid-energy system to perform soft-islanding is presented in Section 4.6.2. The sizing is followed by results of a simulation study of a complete year, to obtain the DoA for this configuration (Section 4.6.3). Lastly, conclusions are presented in Section 4.6.4. Additional details on Markluiden and an expanded case study are presented in [100].

\subsubsection{Characteristics OF THE NeighbOURHOOD}

In Figure 4.13 a layout of the Markluiden neighbourhood is given. The neighbourhood consists of 16 fully detached houses, which are all different. The residents are open to share data about their energy usage and schedules, and are willing to share their locally generated energy with their neighbours. Moreover, the residents filled out questionnaires to provide the information required for this case study.

Most of the houses were built several decades ago, with little to moderate insulation. The average heat resistance $\left(\mathrm{R}_{\mathrm{c}}\right)$ is $1.3 \mathrm{~K} / \mathrm{kW}$, with $0.5 \mathrm{~K} / \mathrm{kW}$ as the lowest value. There are two exceptions, which are very well insulated houses, built recently, where in the best case the $R_{c}$ is $4.1 \mathrm{~K} / \mathrm{kW}$. Only one of the houses currently makes use of renewable energy technology. It is outfitted with 12 PV-panels and 2 PVT-panels ${ }^{3}$. In total 11 of the 16 houses are suitable for the installation of PV-panels. The remaining houses have a thatched roof (i.e. made of straw), which makes installation of PV-panels impossible. For these houses it is assumed that PV-panels will be installed elsewhere on the property (i.e on a shed or annex). In most of the houses, the heat is generated by a traditional high-efficiency gas boiler and delivered to the indoor area using high-temperature radiators. Additionally, 7 houses use floor heating for the living room. In only one of the houses floor heating is used as the only means of heating. The orientation of the houses is mixed, with seven houses East-West oriented and the remaining nine South-North oriented. The window area of the houses is specified based on standardized values depending on the year of construction and type of house [101]. The resulting area is then divided evenly over all four sides

3Photovoltaic Thermal hybrid solar collector panel 


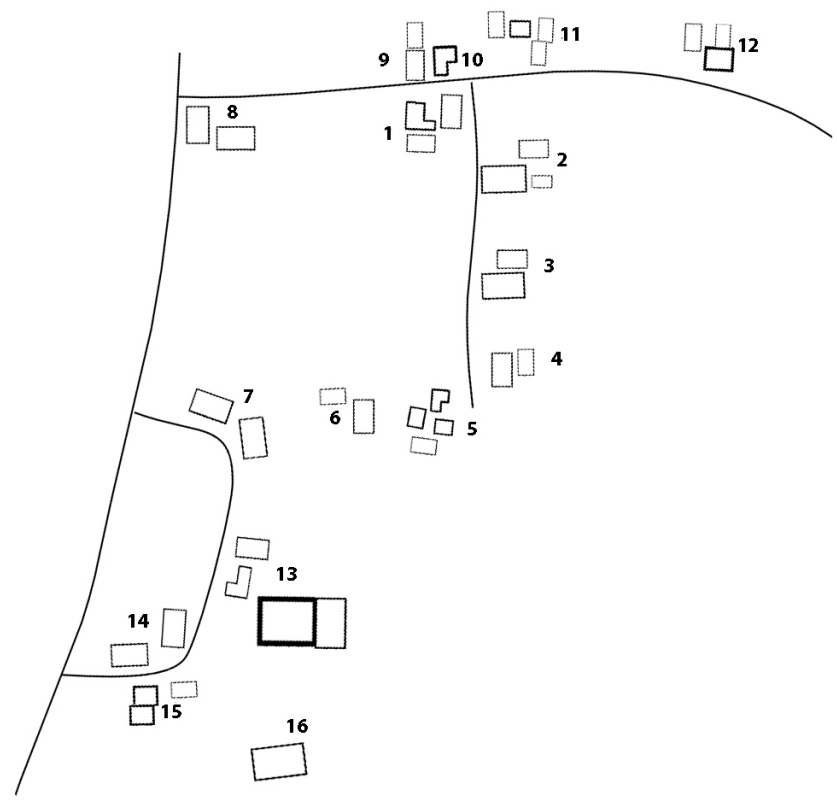

Figure 4.13: Layout of the 16 house neighbourhood in Markluiden.

of the building, whereby the given position of the houses in an online map is taken into account. On average the houses have a window area of $31 \mathrm{~m}^{2}$, divided in $4.5 \mathrm{~m}^{2}$ facing north, $8 \mathrm{~m}^{2}$ facing west, $7.8 \mathrm{~m}^{2}$ facing east and $10.6 \mathrm{~m}^{2}$ facing south.

\subsubsection{SizING THE EQUiPMENT}

In this section the proper size of the energy generating and storing devices (CHP unit, PV-panels, battery) is determined, to be able to reach a scenario where the neighbourhood can be self-supplying for a large part of the year. As input for this, the energy demand of the houses is needed. As before the ALPG [71] is used to generate these profiles. The necessary characteristics, like family composition and work schedule, are used as input to generate a time series of power and heat consumption for the whole year and are taken from the available information of the neighbourhood and the questionnaires. This results in the base model of the neighbourhood, to which technologies that enable soft-islanding, are added and sized accordingly. Note that the comfort of connected customers may not be violated, i.e. they need to be supplied with the heat and electricity they demand. 
The equipment sizing process used in the case study is slightly different than presented in Section 4.3.2. The reasons that prompted this deviation are addressed in Section 4.6.4. Rather than sizing all devices simultaneously, a three step approach was used:

- Firstly, the CHP is sized to fulfil the heat demand during the colder months. Electricity is also produced, however this is considered to be a (useful) by-product. In this particular case enough electricity is produced by the CHP to fulfil the demand during the colder months.

- Secondly, as the CHP already provides enough electricity during the colder months, the number of PV-panels is determined to ensure that enough electricity is generated during the warmer and sunnier months, where the CHP does not provide enough electricity.

- Thirdly, the battery storage is sized to match supply and demand of electricity throughout the day by shifting energy in time, e.g. shifting electricity produced by PV to the evening, thus reducing both the electricity demand from and supply to the grid.

For the sizing, as before three weeks with varying properties are considered. Week A in the summer has a high production of electricity by the PV-panels and a low heat demand, week $\mathrm{B}$ in the winter has a low production of electricity by the PV-panels and a high heat demand and week C in the autumn has both a low electricity production by the PV-panels and a low heat demand (see Table 4.8). The weather data used in this work was obtained from [86].

Table 4.8: Description of the test weeks.

\begin{tabular}{llll}
\hline Week & Date & PV generation & Heat demand \\
\hline A & 30 Jul. - 5 Aug. & very high & very low \\
B & 22 - 28 Jan. & low & very high \\
C & 15-21 Oct. & low & low \\
\hline
\end{tabular}

\section{The CHP unit}

The only source for heating and hot tap water is the CHP unit shared by all houses. As the comfort of the residents is the most important constraint, the capacity of the CHP unit must be large enough to satisfy the heat demand of all houses in the coldest week of the year (i.e. week B) ${ }^{4}$. The setpoint selected to trigger the heating device during the day is set to $18.0^{\circ} \mathrm{C}$. Furthermore, the minimum allowed temperature in the house during night hours (between 23:00 and 8:00) is $14.0^{\circ} \mathrm{C}$. In Figure 4.14, the average room temperature in week B for different $\mathrm{CHP}$ unit capacities (from $100 \mathrm{~kW}$ th $250 \mathrm{~kW}$ th ) is given. For the $\mathrm{CHP}$ a heat to electricity production ratio of 2.25 is assumed.

\footnotetext{
${ }^{4}$ Note that it would also be prudent to improve the thermal insulation wherever possible, however, this has not been taken into account in this study.
} 


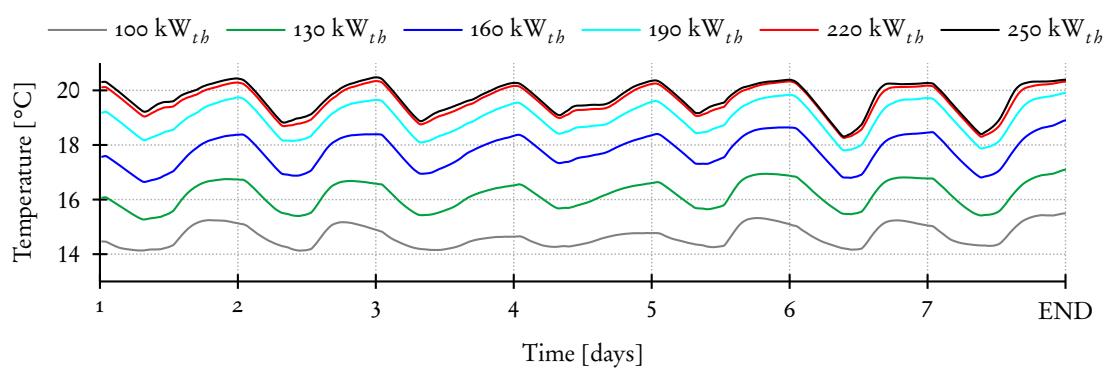

Figure 4.14: Average zone temperature in week B for varied CHP sizes.

From Figure 4.14 it can be derived that CHP units with a capacity above 190 $\mathrm{kW}_{t h}$ can guarantee the thermal comfort inside the houses. However, looking at the individual temperature profiles of each household shows that a CHP capacity of $190 \mathrm{~kW}_{t h}$ does only guarantee thermal comfort on average, but not for all houses (these are the less insulated houses). A CHP unit with $250 \mathrm{~kW}_{t h}$ power output is the minimum capacity that can ensure thermal comfort in all the houses of the micro-grid, and hence this size is selected. Note, that electricity is produced by the CHP as a by-product from the heat-generation and can be used to fulfil a part of the electricity demand. The remaining electricity demand should be provided by the PV-panels and the batteries. Possible overproduction of electricity can be stored locally in the batteries or fed back to the main grid. Instead of a normal heat buffer it is assumed that the neighbourhood makes use of a aquifer thermal energy storage (ATES) system as heat storage for the CHP. Hence, the sizing of a thermal buffer as considered in [H:1] is not necessary in this case.

\section{The ATES system}

The ATES technology takes advantage of underground water deposits as medium to store heat over a long period. Hence, ATES may provide the neighbourhood with inter-seasonal heat storage, adding flexibility by matching the heat (over)production in warmer periods to the heat demand in colder periods. The residents of the Markluiden neighbourhood have decided to use an ATES system. Note that it still has to be investigated if an ATES system is feasible in the area of the neighbourhood. Furthermore, the sizing of such a system has to be investigated. For the research in this thesis a capacity of $5 \mathrm{MWh}_{\mathrm{th}}$ is chosen. A proper analysis to determine a best size is beyond the scope of this work. For more information on these two issues, see [100].

\section{The PV-panels}

The sizing of the required PV-panel area is done based on an analysis of week $A$. This is the warmest week and by that the CHP will produce the least electricity 
and thus the micro-grid depends mainly on the production from the PV-panels. For the PV-panels a 19\% efficiency is considered, since these panels are already used in the neighbourhood. Furthermore, the PV-panels are assumed to be installed facing south wherever possible, and equally divided towards east and west in all other cases. For the considered total surfaces of PV-panels per household areas from $8 \mathrm{~m}^{2}$ to $24 \mathrm{~m}^{2}$ are considered. Lastly, in this determination a battery of sufficient capacity $(13.5 \mathrm{kWh})$ per household is used to avoid capacity limitations in shifting energy from day to night. Note, that this capacity is not the optimal battery capacity yet. The optimization of the battery capacity itself is considered in the next step, where trade-off's between autarky and costs are made.

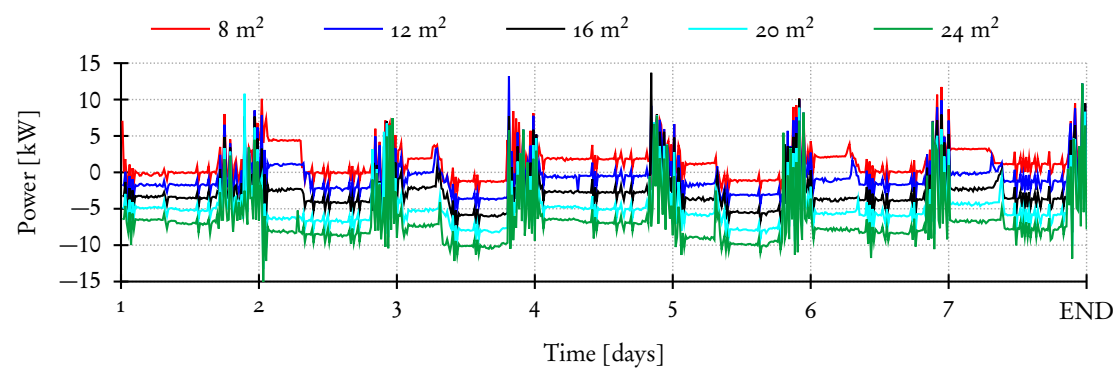

(a) Electricity usage

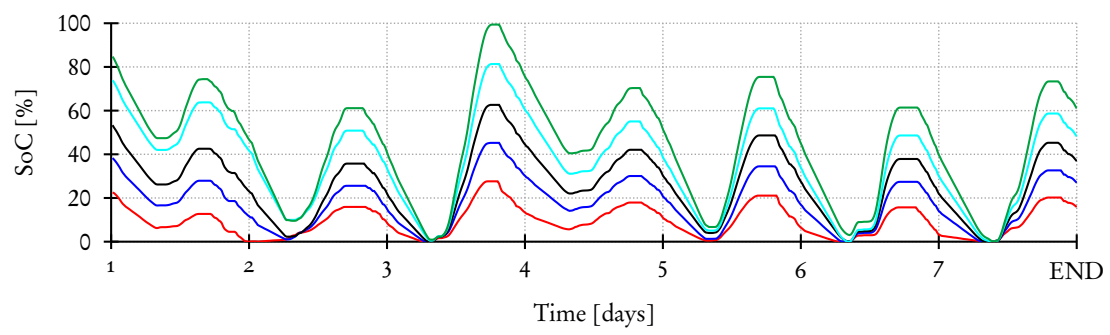

(b) SoC batteries

Figure 4.15: Electricity usage and battery SoC in week A for varied PV areas.

Figure 4.15a shows the optimized electricity usage of the whole micro-grid given the different values for the PV-panel area per house, while Figure $4.15 \mathrm{~b}$ shows the resulting SoC of the battery over time. For clarity, the values of the largest electricity import and export in week A are presented in Table C. 2 in Appendix C. From Figure $4.15 \mathrm{a}$ it is clear that even for the highest PV installation (24 $\mathrm{m}^{2}$ ), some electricity is still imported from the grid, mostly at night. Figure 4.16a gives the amount of electricity imported from the grid during week $\mathrm{A}$, depending on the PV-panel area. It is clear that the benefits beyond $16 \mathrm{~m}^{2}$ of PV-panels per household is very limited. Hence, also taking into account the cost of PV-panels, a PV-panel area of $16 \mathrm{~m}^{2}$ per house is selected. 


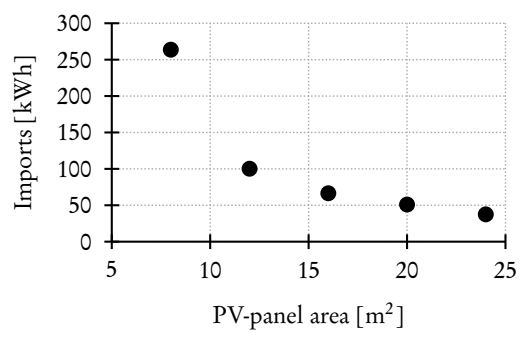

(a) PV-panel area

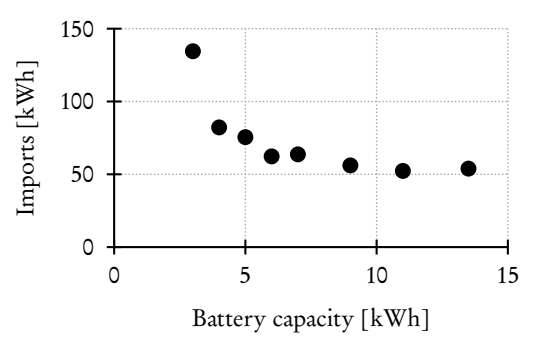

(b) Battery capacity

Figure 4.16: Necessary electricity imports for the considered battery capacities and PV-panel areas during week A.

\section{The batteries}

The sizing of the capacity of the electrical storage is also based on an analysis of week $A$. For this analysis battery capacities of $3,4,5,6,7,9,11$ and $13.5 \mathrm{kWh}^{5}$ are considered. In Figure 4.17 the electricity import and export of the micro-grid and the state-of-charge (SoC) over time of the batteries are given.

From Figure $4.17 \mathrm{a}$, it is clear that the total import from the grid decrease when the battery capacity is increased. Figure $4.16 \mathrm{~b}$ shows the amount of electricity import during week A given the different battery sizes. Again, for clarity, the values of the largest electricity import and export in week A are presented in Table C. 3 in Appendix C. With a total battery capacity of $3 \mathrm{kWh}$ per household $(48 \mathrm{kWh}$ in total), almost $135 \mathrm{kWh}$ of electricity is still imported from the grid. By increasing the battery capacity to $6 \mathrm{kWh}$ per household the import is reduced to just over $62 \mathrm{kWh}$. However, beyond this $6 \mathrm{kWh}$ per household, the improvement is only marginal. Moreover, it is observed that the full capacity of a battery of more than $6 \mathrm{kWh}$ is never fully utilized, i.e. the SoC never reaches $100 \%$ (see Figure $4.17 \mathrm{~b}$ ). Together with the fact that still electricity is imported from the grid, this implies that the PV-panels do not produce sufficient electricity to supply the complete demand. So increasing the battery capacity any further does not yield improvements and thus a battery of $6 \mathrm{kWh}$ per household is selected.

\subsubsection{Results}

Using the technologies as sized in Section 4.6.2 (see Table 4.9 for a summary), the Markluiden soft-islanded microgrid is simulated for one year using DEMKit [20], to evaluate its potential for two specific cases. The first case is the NC case, in which no control and optimization is applied, nor batteries are used. For the second case (PSA case) optimization of storage and CHP operation is

\footnotetext{
5The capacity $13.5 \mathrm{kWh}$ corresponds to a Tesla Powerwall 2 battery, this specific battery is taken into account on the request of the Markluiden residents.
} 

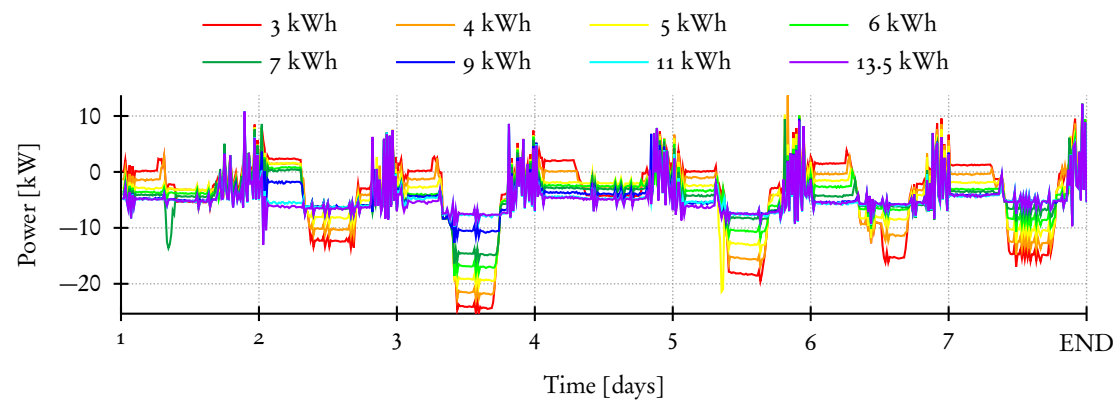

(a) Electricity usage

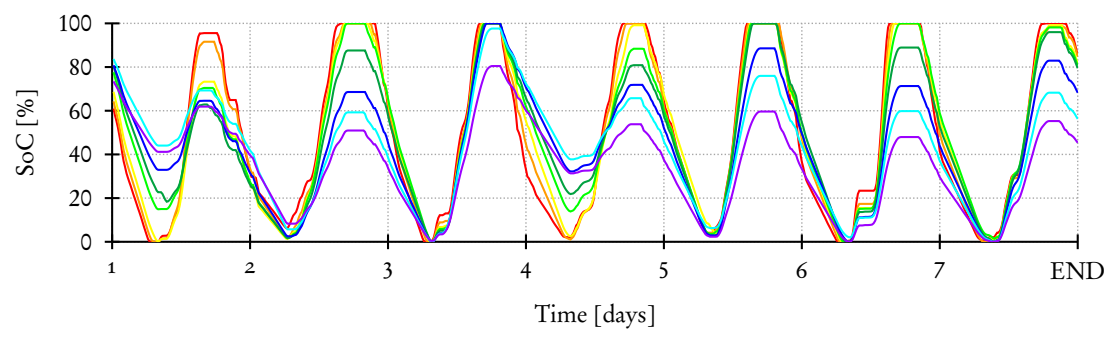

(b) SoC batteries

Figure 4.17: Electricity usage and battery SoC in week A for varied battery sizes

considered, using the profile steering control as discussed in Section 4.2.3. The two different cases are then compared with the present situation in Markluiden, the $R$ (reference) case. To specify to which extent the energy consumed within the system is also locally produced, the DoA is used (see Section 4.2). A summary of the main outcomes of the three simulations is given in Table 4.10.

Table 4.9: Equipment size and configuration.

\begin{tabular}{ll}
\hline Equipment & Size and configuration \\
\hline CHP unit & $250 \mathrm{~kW}_{\text {th }} / 111 \mathrm{~kW}$ el \\
CHP buffer & $5 \mathrm{MWh}$ (ATES) \\
Battery & $6 \mathrm{kWh} /$ house \\
PV-panels & $16 \mathrm{~m}^{2} /$ house $(19 \%$ eff.) \\
\hline
\end{tabular}

Note, that in the $\mathrm{R}$ case, almost the entire electricity load comes from the grid. Only a small percentage of the total electricity demand of the 16 houses comes from the PV-panels installed on the rooftop of one house. Consequently, the energy system is far from (soft-)islanded, with a resulting DoA of only $3.7 \%$.

In the NC case, the yearly average electricity consumption per house is $3.7 \mathrm{MWh}$ while the average electricity production per house is $16 \mathrm{MWh}$ (see Table 4.10). 
The average heat demand per house is $19.6 \mathrm{MWh}_{t b}$, which is completely satisfied by the heat produced by the CHP. The majority of the electricity (12.2 MWh per house) is generated by the CHP as a by-product of the heat generation. However, only 2.0 MWh of this production is used locally. The PV-panels generate 3.8 MWh per house over the year of which only $830 \mathrm{kWh}$ is consumed locally. The excess electricity produced by the CHP and PV-panels is $13.1 \mathrm{MWh}$ per house for the entire year and is exported to the grid. On the other hand, $840 \mathrm{kWh}$ is still imported. This yields a DoA of $77.3 \%$, i.e. just over three quarters of the electricity load of the neighbourhood does not burden the grid. Although, this is a remarkable improvement compared to the $\mathrm{R}$ case, it is still far from soft-islanding the neighbourhood.

Table 4.10: Statistics of the annual household electricity usage.

\begin{tabular}{llllll}
\hline Case & $\begin{array}{l}\text { Import } \\
{[\mathrm{kWh}]}\end{array}$ & $\begin{array}{l}\text { Export } \\
{[\mathrm{kWh}]}\end{array}$ & $\begin{array}{l}\text { Production } \\
{[\mathrm{MWh}]}\end{array}$ & $\begin{array}{l}\text { Consumption } \\
{[\mathrm{MWh}]}\end{array}$ & $\begin{array}{l}\text { DoA } \\
{[\%]}\end{array}$ \\
\hline R & 4489.4 & 0.0 & unknown & 4.5 & 3.7 \\
NC & 839.27 & 13146.2 & 16.0 & 3.7 & 77.3 \\
PSA & 401.5 & 12612.1 & 16.7 & 4.5 & 91.1 \\
\hline \hline \multicolumn{5}{c}{ Share in electricity supply [\%] } \\
& \multicolumn{6}{c}{ Grid } & PV & CHP & BAT \\
\hline R & 96.3 & 3.7 & 0.0 & 0.0 \\
NC & 22.8 & 22.4 & 54.9 & 0.0 \\
PSA & 8.9 & 30.9 & 51.9 & 8.3 \\
\hline
\end{tabular}

In the PSA case, where energy storage is added, and a double-sided auction control is applied, the results, compared to the NC case, are somewhat different. The yearly average electricity consumption is $4.5 \mathrm{MWh}$ per house, while the production per house is $16.7 \mathrm{MWh}$. The increase in both production and consumption per house is mainly attributed to the battery, as discharging the battery is counted as production and charging the battery is counted as consumption. Still, the majority of the electricity (12.2 MWh per house) is generated by the $\mathrm{CHP}$ as a by-product of the heat generation. However, only 2.3 MWh of this is used locally. The PV-panels generate $3.8 \mathrm{MWh}$ per house per year of which 1.4 MWh is used locally. Furthermore, the average yearly electricity import has decreased, by over $50 \%$, to $402 \mathrm{kWh}$ per house. The average yearly export per house is decreased to $12.6 \mathrm{MWh}$. This yields a DoA of $91.1 \%$, which is clearly an improvement to the NC case. Moreover, the battery usage is very limited, meaning that only $400 \mathrm{kWh}$ (or $8.3 \%$ ) of the total electricity demand is provided by the battery. 


\subsubsection{IN CONCLUSION}

In this section, the concepts and methods discussed in Sections 4.2 and 4.3 are applied to the neighbourhood of Markluiden, using the data provided by the residents. The achieved results indicate that the stated goals can be achieved to a certain extent, however, realizing a soft-islanded MES for this particular neighbourhood is currently still infeasible.

When storage and optimal control are used for the soft-islanding approach, a DoA of $91.1 \%$ can be achieved. In this case, the electricity imported from the grid amounts to $402 \mathrm{kWh} /$ year. However, the amount of electricity exported to the grid is quite high, at $12.6 \mathrm{MWh} /$ year, meaning that the neighbourhood has quite a serious overproduction of energy. This is a very different operation compared to the present situation in Markluiden ( $R$ case), where almost the entire electricity load is imported from the grid, with a resulting DoA of $3.7 \%$. The large exports of electricity are clearly a consequence of the large heat demand, which implies that the $\mathrm{CHP}$ is producing too much electricity while fulfilling the heat demand. As a consequence, the part of the year where the electricity production is dominated by the PV-panels is only 16 weeks.

The substantial reduction of electricity imports from the grid between the $\mathrm{R}$ case (4.5 MWh/year) and PSA case (0.4 MWh/year), shows that the soft-islanding approach can lead to a largely sustainable electricity supply when using bio-fuel for the CHP. However, aiming for a low electricity import and resulting low DoA in this case may have negative consequences. Since, in both the NC and PSA case there is a significant electricity export due to the overproduction of electricity by the CHP. This may lead to an increased strain on the electricity grid compared to the $\mathrm{R}$ case.

Based on the above, it is concluded that before installing a CHP, PV-panels and batteries, first other steps are needed. For these steps, it would be prudent to use the steps of Trias Energetica [29] and start by applying its first rule: "Limit energy usage by reducing losses". This implies that the houses should be properly insulated, so energy losses are reduced, before any renewable energy sources are added or soft-islanding solutions are applied.

An added challenge for the Markluiden case-study was taking into account the wishes of the residents of Markluiden. For example, the residents requested the Tesla Powerwall 2 battery would be taken into account, the capacity of which $(13,5 \mathrm{kWh})$ was rather illogical looking at the battery sizing analysis. Another example is their request to use an ATES system in the multi-energy system. This required a separate analysis for the $\mathrm{CHP}$ size, which in turn made the simultaneous sizing of the CHP, PV-panels and batteries (see Section 4.4) impractical, prompting the (time consuming) three step approach that was actually used. 


\subsection{Conclusions}

In this chapter the integration of batteries in multi-energy smart-grids is explored. To do this, a case discussed in [H:1] was revisited and simulated anew using the simulator, models, methods and techniques developed or improved since the publication of [H:1]. Firstly, the possibility of operating an idealized neighbourhood (almost) disconnected from the national electricity grid in the Netherlands is researched. Secondly, the possibility of operating a real neighbourhood, located in Markluiden, the Netherlands, disconnected from the grid is investigated. To be able to make fair comparisons, a new metric, the Degree of Autarky is introduced as a measure of how far one can operate a neighbourhood as an islanded microgrid. Hereby the concept of soft-islanded microgrids, introduced in [H:1] is expanded by adding a means of quantification.

To support the determination of the proper size (and configuration) of all equipment used in the neighbourhood, a method of simultaneous equipment sizing is proposed. It is concluded that this methodology, as demonstrated in Section 4.4, proved to be quite effective. The selection of "worst case scenarios" (i.e. Table 4.3), negates the need for whole year simulations and speeds up the process. The ability to focus on the analysis of only one characteristic value for each simulation (the total weekly grid power demand in $\mathrm{kWh}$ ), results in a quick and comprehensive way to find the best size and configuration of the equipment in the neighbourhood. In this chapter, the focus is mainly on sizing the PV-panel area, the CHP heat to power ratio and the battery capacity, but conceivably other characteristics like the efficiency of the PV-panels or the size of the CHP buffer can also be taken into account. If equipment prices are known, the achieved results could lead to a powerful tool, which e.g. can be used to relate the increase in DoA to an increase in equipment costs, which is valuable information for investors and other executives.

In general, it is concluded that Soft-islanded microgrids are able to fulfil their energy demand most of the time from locally produced electricity, but they should remain connected for grid stabilization. Hereby, the level of comfort stays the same as for a normal neighbourhood, meaning that all heat and electricity demands are met at all times.

\subsubsection{The IDEAL NeIGHbOURHOOD}

The idealized neighbourhood is a futuristic "greenfield" neighbourhood which has features, like e.g. the state of the art of isolation. Each house is equipped with a $4 \mathrm{kWh}$ battery, 22.4 $\mathrm{m}^{2} \mathrm{PV}$-panels and the houses share a $60 \mathrm{~kW}_{\mathrm{th}} /$ $30 \mathrm{~kW}_{\mathrm{el}} \mathrm{CHP}$ unit. The sizing of these equipments is detailed in Section 4.3. The results of the sizing and simulations indicate that either substantial battery storage or overproduction from renewable sources is required to achieve an (nearly) autarkic operating microgrid. The over-all best results are gained in the PSE case, (i.e. batteries are placed in each house and profile steering is applied), 
with a DoA of $99.1 \%$. Electricity imports from the grid are limited to only 36.5 $\mathrm{kWh}$ /year. However, 5.1 MWh/year is still exported to the grid. The results over a whole year indicate that in all cases the PV installations are "overdimensioned" in the sense that less than half of all locally generated energy is consumed locally. Hereby, again the PSE case performs best at $43.7 \%$.

A comparison between the PSE scenario and the PSE-B scenario, (where the difference is that the DiBu-model is used) results in a $1.8 \%$ lower self-consumption, 9.3 \% less electricity buffered, a $0.7 \%$ lower DoA and a $40.8 \%$ higher electricity import from the grid. Overall, the observations show that by using profile steering in general no high discharge peaks and high charge powers occur, such that the realistic battery can closely follow the original planning. Moreover, the PSE- $B$ case yields more realistic results, and answers the question what DoA can be reached for a given battery capacity more accurately.

Concerning the energy mix, the CHP is able to provide the required electricity with a relative small heat buffer as both heat demand and electricity demand usually coincide. This is also indicated by the small share of electricity generated by the CHP which is stored in the batteries (see Tables 4.5 and 4.6). Therefore, the ratio of heat to electricity generation of the CHP should ideally match the ratio of heat to electricity demand.

Concerning the PV-panels, the situation is different as here the battery storage capacity is dominant. However, significant overproduction of electricity by both CHP and PV reduce the required size of the batteries. As for the batteries, capacity itself seems to be more important than the power rating, as shown with the realistic DiBu battery model. With only a quarter of the maximum charging power, the microgrid is still able to capture enough electricity from PV systems to operate nearly autarkic.

Generally it is concluded that complete islanding of the neighbourhoods would be very costly. On the one hand, to reduce the electricity imports an unrealistic amount of electrical energy storage should be installed, most of which will only be used a few hours per year. On the other hand, to reduce the electricity exports, the CHP should produce no more electricity than strictly necessary, which implies that heat-demands are not met at all times, which causes a loss of comfort and thus is not acceptable. Therefore, soft-islanding is a better solution. In the best soft-islanded case (PSE) only $36.5 \mathrm{kWh} /$ year (or $0.1 \mathrm{kWh} / \mathrm{day}$ ) is imported, which is considered a marginal load for the grid. However, the resulting overproduction of electricity in the soft-islanded case can potentially stress the grid. For the part of the electricity generated by the PV-panels this can easily be solved by performing curtailment. However, this is not possible for the part of the electricity generated by the CHP. An alternative solution may be to take into account a limit for the amount of electricity that can be delivered back to the grid when making the choice for the proper heat to electricity ratio of the CHP. 


\subsubsection{The ReAl neighbourhood in MARKLUiden}

The considered real neighbourhood is located in Markluiden and the characteristics of this neighbourhood were obtained from questionnaires filled out by the residents. Each house is equipped with a $6 \mathrm{kWh}$ battery, $16 \mathrm{~m}^{2} \mathrm{PV}$-panels and the houses share a $250 \mathrm{~kW}_{\mathrm{th}} / 111 \mathrm{~kW}_{\mathrm{el}} \mathrm{CHP}$ unit. The sizing of these equipments is detailed in Section 4.6.2. The best results are achieved in the PSA case, where storage and optimal control are used. The resulting DoA is $91.1 \%$. In this case, the electricity imported from the grid amounts to $402 \mathrm{kWh} /$ year. However, the amount of electricity exported to the grid is quite high, at $12.6 \mathrm{MWh} / \mathrm{year}$, meaning that the neighbourhood has quite a serious overproduction of energy.

In the NC case, more of the electricity generated by the PV-panels is used locally and less electricity is imported from the grid. However, for both the NC and PSA case, the largest part of the consumed electricity is provided by the CHP unit. This is due to the high heat demand, which results in a CHP producing too much electricity to fulfil the heat demand. Th resulting operation of the system is very different to the present situation in Markluiden ( $R$ case), where almost the entire electricity load is imported from the grid, with a resulting DoA of $3.7 \%$.

\subsubsection{BOTH NEIGHBOURHOODS COMPARED}

In Table 4.11 the proper equipment size for both neighbourhoods, used in the final simulations, is displayed.

Table 4.11: Summary of equipment sizing.

\begin{tabular}{lll}
\hline Equipment & \multicolumn{2}{c}{ Size and configuration } \\
& Ideal & Markluiden \\
\hline CHP unit & $60 \mathrm{~kW}_{\text {th }} / 30 \mathrm{~kW}_{\mathrm{el}}$ & $250 \mathrm{~kW}_{\text {th }} / 111 \mathrm{~kW}_{\mathrm{el}}$ \\
CHP buffer & $250 \mathrm{kWh}$ & $5 \mathrm{MWh}$ (ATES) \\
Battery & $4 \mathrm{kWh} /$ house & $6 \mathrm{kWh} /$ house \\
PV-panels & $22.4 \mathrm{~m}^{2} /$ house $(16 \%$ eff. $)$ & $16 \mathrm{~m}^{2} /$ house $(19 \%$ eff.) \\
\hline
\end{tabular}

While the battery capacity and PV-panel area are similar for both neighbourhoods, there is a large difference between the capacity of the heat storage devices and the power of the CHP. Specifically, the neighbourhood in Markluiden needs a CHP four times more powerful than the ideal neighbourhood, and a storage capacity twenty times larger.

The difference between the neighbourhoods becomes even more clear in Figure 4.18, where the weekly electricity production and demand for the whole simulated year is shown. The electricity produced by the PV-panels is roughly the same for both neighbourhoods, however, the share in the total electricity production is quite different. While the shares of electricity produced by the CHP and PV-panels are roughly equal and complementary for the ideal neighbourhood, 


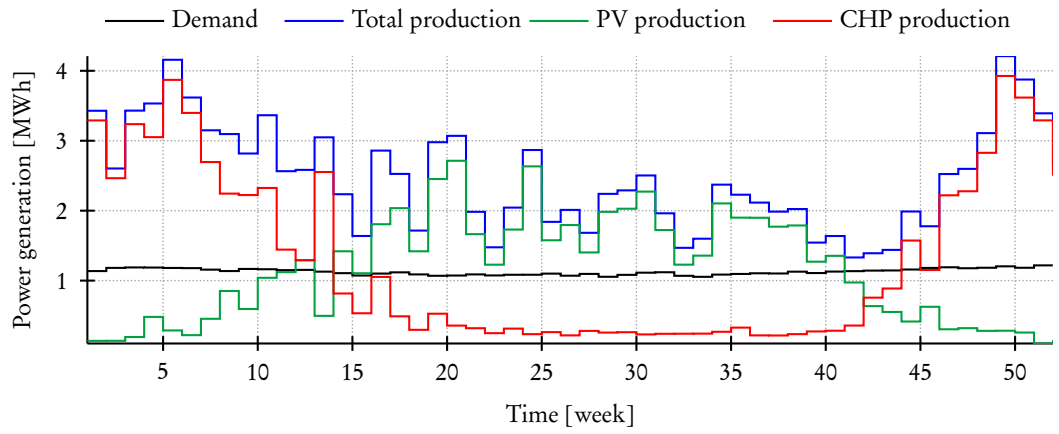

(a) The ideal neighbourhood.

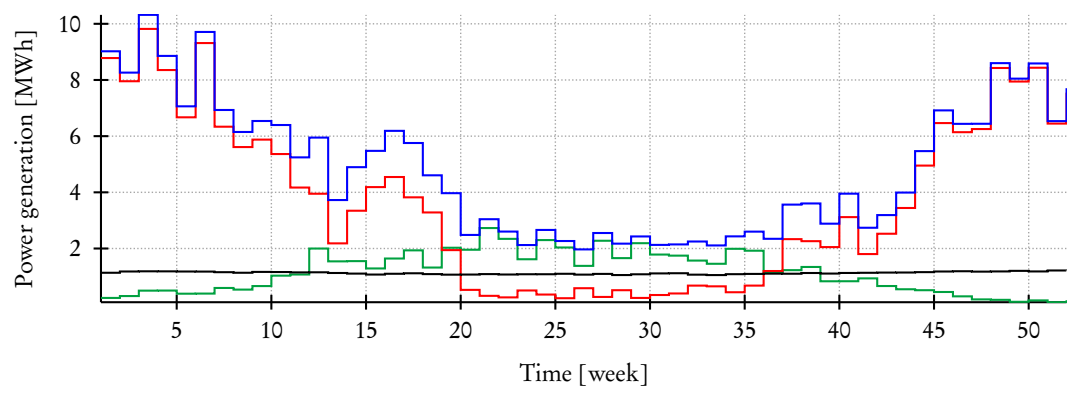

(b) The neighbourhood in Markluiden.

Figure 4.18: Weekly electrical energy production of the CHP and all PV-panels combined, resulting from sizing choices.

the share of electricity produced by the PV-panels in Markluiden is only a small part. In the ideal neighbourhood as well as in Markluiden the electricity demand is met by electricity generated by the PV-panels for roughly 30 weeks in the year. During the other weeks the CHP produces enough electricity to meet the demand. In the ideal neighbourhood, the electricity production is dominated by the PV-panels for 28 weeks of the simulated year (weeks 14-42) whereas this is only for 16 weeks (week $20-36$ ) for the neighbourhood in Markluiden.

The electricity production in the ideal neighbourhood coincides quite well to the demand, although there is some overproduction in the weeks where the CHP is most active. The overproduction is limited to $1.37 \mathrm{MWh} /$ week on average, with the highest overproduction (3.01 MWh/week) occurring in week 49. The maximum production is $\sim 2.5$ larger than as the demand at the time. In Markluiden, however, the match between demand and production is not that good, on average there is an overproduction of electricity of $3.76 \mathrm{MWh} /$ week. The highest overproduction (9.13 MWh/week) occurs in week 4, which is approximately 7.5 times as large as the demand at the time. 
As the electricity production by the CHP is only a by-product of the heat generation, it is concluded that before a CHP, PV-panels, batteries, and smart control are used in the Markluiden neighbourhood, the thermal demand should be reduced, through e.g. better insulation of all houses. 
106 


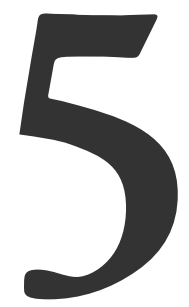

\title{
The Seasalt Battery
}

\begin{abstract}
In this chapter the Seasalt battery is evaluated and discussed in detail. The Seasalt battery is a durable and environmentally responsible alternative to e.g. lithium-ion and lead-acid batteries in home energy storage systems. A detailed description of the battery and its behaviour is given, and where possible compared to the aforementioned batteries. In addition the advantages and disadvantages are discussed. The advantages include the usage of environmentally friendly, sustainable and abundantly available materials in its construction, and limited risks to health and safety, compared to lead-acid and lithium batteries. Disadvantages include a lower capacity / weight and capacity / volume ratio in comparison with the aforementioned batteries.

Furthermore, the DiBu-model for battery SoC prediction is applied to predict the SoC of the Seasalt battery and some examples of Seasalt batteries applied in household settings are presented. It is concluded that, although there remain some issues to be addressed and problems to be solved, the Seasalt battery is a viable and promising battery for application in household and neighbour. hood energy systems.
\end{abstract}




\subsection{INTRODUCTION}

In Chapters 1, 2 and 4 of this thesis it has been discussed extensively that batteries will become an important asset of the future energy systems. Different types (i.e. chemistries) of batteries are currently already applied for electricity storage in energy systems at the house and neighbourhood level [102]. Two important examples are lead-acid (Pb-acid), and lithium-ion ${ }^{1}$ (Li-ion) batteries, which have already been discussed and used for comparisons in previous chapters. Other examples include sodium-sulphur, nickel-cadminum and vanadium based batteries $[103,104]$, each of which have advantages and disadvantages $[105,106]$.

The Pb-acid battery technology is well established and has been refined and improved since its invention in 1859 . Despite its relatively low capacity/volume and capacity/weight ratios the battery is widely used in automotive systems and in standby and emergency backup electricity systems [103, 107]. The main disadvantage is the lead itself, since lead is classified Dangerous, a Severe health hazard and Dangerous to aquatic life [108]. Moreover, lead is persistent, meaning that it can not be broken down by plant and animal life, so once it is in the food-chain it remains there. Hence, if the right precautions are not taken during manufacturing and usage, or worn out batteries are not properly disposed, there could be considerable health risks $[109,110]$.

A further technology is the Li-ion battery. Lithium based batteries are well known for high capacity/volume and capacity/weight ratios. This is a great advantage, as even batteries of a large capacity are still relatively light and small. Hence, this technology is widely applied in mobile electronic devices [111]. However, the main disadvantage of Li-ion batteries also stems from the high capacity / volume and capacity / weight ratios. Most types of Li-ion batteries contain a variety of combustible materials, and could suffer a Thermal runaway [38]. This means, that 1) a short-circuit can cause a Li-ion battery to heat up and catch fire, 2) deformation of the battery can cause a short-circuit, and 3) heat can cause a battery to expand or deform. So, the occurrence of either 1,2 or 3 could result in a Li-ion catching fire [112]. Moreover, a thermal runaway is amplified if multiple Li-ion batteries (or cells) are in close proximity to each other. Hence, Li-ion batteries have a considerable fire hazard $[37,113]$. The Dutch fire department takes this hazard very seriously and advises to supervise $L i$-ion batteries when they are being charged [114].

However, there are also more sustainable and environmentally friendly alternatives for these battery technologies [34]. One such alternative technology, that could be used in future energy systems are zinc-based batteries. The zinc-based primary battery (i.e. not rechargeable) has been around in the world of energy storage since the 1970's [115, 116]. Although research is still ongoing [117], a useful and cost-effective secondary (i.e. rechargeable) zinc based battery still has

\footnotetext{
${ }^{1}$ Note that the lithium-ion polymer $($ Li-Poly $)$ and lithium ironoxide ( $\left.\mathrm{LiFePo}\right)$ batteries, discussed in e.g. Chapter 2, are specific types of lithium-ion (Li-ion) batteries.
} 
not been fully developed. One possible zinc based secondary battery is currently under development at Dr Ten B.V., it is called the Seasalt battery.

The Seasalt battery was first conceived by electro-chemist Marnix ten Kortenaar, when he was visiting Namibia, Africa. While he was there he observed people transporting $\mathrm{Pb}$-acid batteries from villages connected to an electricity grid to villages that were not connected, and back again. These people made money by charging their batteries, transporting them to where electricity was needed and selling the electricity where it was needed. However, due to ageing and transport damage, these people would earn more money by using newer batteries, implying that older and damaged batteries were discarded. These discarded batteries for a large part ended up in the garbage, meaning that the lead and other battery components would reach the ground water and would harm people drinking that water, i.e. lead poisoning. Marnix ten Kortenaar determined that one solution to this problem would be a battery that would be more durable, and made of components that are less harmful to the environment. This would imply that batteries are replaced less often, and that the components of (improperly) disposed batteries are less harmful to the environment.

The Seasalt battery has been under development since 2008. Firstly by Marnix ten Kortenaar himself and subsequently at Dr Ten B.V. (after its foundation in 2010) in a group effort with various collaborators (most notably Diego Quintero and Bart Homan). Part of the research done for this thesis has been applied to (or used in) the continuing development of Seasalt battery. More precisely, contributions are made to the (electro-) chemical make-up (discussed in more detail in Chapter 6), the cell and casing design, the characterization and the practical implementation.

In this chapter the Seasalt battery is evaluated and discussed. Firstly, in Section 5.3 a high-level overview of various aspects of the design of the Seasalt battery is presented. In Section 5.4 the characteristics of the Seasalt battery and aspects of its behaviour are presented, and the advantages and disadvantages of this battery type are discussed. In Section 5.5 the accuracy of the DiBu-model for Seasalt batteries is tested, in a similar fashion as the tests presented in Chapter 2. In Section 5.6 the challenges and results of some practical tests of the Seasalt batteries in energy storage applications at the household level are presented. Lastly, conclusions are presented in Section 5.7.

\subsection{Materials \& Methods}

The voltage and current measurements of lab-scale tests presented in the following sections are performed using a Vencon $\mathrm{UBA}_{5}$ battery analyser [63], under standard conditions. This battery analyser has a voltage accuracy of $\pm 0.2 \%$ and a current accuracy of $\pm 0.5 \%$.

The practical tests on full scale battery setups, discussed in Section 5.6, are performed using Victron Multiplus inverter equipment [68] connected to a Victron 
Venus control and monitoring equipment. The voltage, current and power measurements are obtained from this equipment. The precise layout of the inverter setup is discussed in Subsection 5.6.2.

\section{$5 \cdot 3$ BATTERY DESIGN}

In this section, the characteristics of the design of the Seasalt battery are discussed. However, because the development of the Seasalt battery is still ongoing at $\mathrm{Dr}$ Ten B.V., certain details of the development and manufacturing, especially relating to (electro)chemical aspects, are not allowed to be freely disclosed. Therefore only a high level overview of the battery design is presented.

To comply to the original vision, as introduced in Section 5.1, the Seasalt battery was designed with three goals in mind, taking precedence over other considerations (e.g. an optimal capacity/volume or capacity/weight ratio). Specifically the Seasalt battery should be:

1. environmentally responsible,

2. durable,

3. affordable.

In the following subsection the incorporation of Aspects 1 and 2 in the design of the Seasalt battery is discussed. Aspect 3, the affordability of the battery, is discussed only in relation to the other aspects, as compromises sometimes have to be made to keep costs manageable.

\subsubsection{ENVIRONMENTALLY RESPONSIBLE}

The Seasalt battery should be environmentally responsible. In the context of a battery, environmentally responsible means that the battery should cause minimal harm to the environment during manufacturing, operation and disposal. Note, that disposal includes dismantling, recycling but also improper disposal (i.e. abandoning the battery somewhere outdoors). To achieve this, only chemicals with the lowest hazard classifications were used in the final design of the Seasalt battery. In the GHS ${ }^{2}$ this is specified as "Warning", which signifies that contact with the chemical may have short term irritating effects on eyes or skin but no long term effects.

Another aspect of making the battery design more environmentally responsible is avoiding the use of rare and hard to obtain materials, in contrast to using materials that are abundant and readily available. The main components used in the Seasalt battery are graphite, bromide salts and chloride salts. These components are both abundant and readily available. The remaining world reserves of graphite are estimated to be around $6 \cdot 10^{8}$ metric tons [118] and graphite can be

${ }^{2}$ Globally Harmonised System of classification and labelling of chemicals [108] 
synthesised (e.g. from silicon carbide). The world reserves of bromide and chloride salts are practically unlimited $[119,120]$, as bromine and chlorine are readily available in the seas $[119,120]$, and the appropriate salts can either be obtained directly from the sea or be synthesised from salts that can be directly obtained. An added benefit of using materials that are abundant and readily available is that these materials tend to be cheap, hence this benefits the affordability of the Seasalt battery.

Table 5.1: Components used in the Seasalt battery and their GHS hazard classification. The hazard classifications were obtained from [108].

\begin{tabular}{lll} 
Component & Role & Hazard classification \\
\hline Electrode & & \\
\hline Treated graphite plate & Anode / Cathode & None \\
Treated graphite felt & Anode / Cathode & None \\
\hline Electrolyte & & \\
\hline Water & Solvent & None \\
$\mathrm{NaCl}_{\text {(aq) }}$ & Main component & None \\
$\mathrm{ZnCl}_{2}$ (aq) & Main component & Warning, Corrosive, \\
& & Danger to aquatic life \\
$\mathrm{NaBr}_{\text {(aq) }}$ & Main component & None \\
$\mathrm{ZnBr}_{2}$ (aq) & Main component & Warning, Corrosive, \\
& & Danger to aquatic life \\
$\mathrm{AlCl}_{3}$ (aq) & Catalyst & Corrosive \\
$\mathrm{MgBr}_{2}$ (aq) & Dendrite prevention agent & Warning \\
$\mathrm{Amine}^{-}$complexes & Stabilizer & n/a \\
Organic surfactants & Stabilizer & n/a \\
\hline \hline Note that the signal words of the GHS classification are meant to invoke caution, to put the classifications "Warn- \\
ing", Corrosive", and "Danger to aquatic life" in perspective: common household cleaners like bleach (toilet cleaner), \\
methylated spirit (window cleaner) and drain cleaner, also have these classifications.
\end{tabular}

The components used in the battery and their hazard classification are listed in Table 5.1. Note, that due to confidentiality, no specific concentrations of the various components of the electrolyte are given. However, generally the concentration of the main components in the electrolyte is much higher than the concentrations of the catalyst, dendrite prevention agent and stabilizer. Both electrodes are comprised of graphite, which has no hazard classification and the solvent used in the electrolyte is simple tap-water which also has no hazard classification [108].

The electrolyte contains several components, foremostly the following four main components: sodium chloride $(\mathrm{NaCl})$ or simple kitchen salt and sodium bromide $(\mathrm{NaBr})$, which have no hazard classification, zinc chloride $\left(\mathrm{ZnCl}_{2}\right)$ and zinc bromide $\left(\mathrm{ZnBr}_{2}\right)$. Zinc bromide and zinc chloride are the most hazardous components in the electrolyte and both are classified as "irritating to the skin", "severely irritating to the eyes", "corrosive" and "dangerous to aquatic life with long term effects", all in the lowest subcategory of the classification [108]. To 
put this in perspective, e.g. bleach (toilet cleaner), methylated spirit (window cleaner) and drain cleaner, which are present in most kitchen sinks, also have these classifications.

The additional components aluminium chloride $\left(\mathrm{AlCl}_{3}\right)$, which is classified "corrosive" and magnesium bromide $\left(\mathrm{MgBr}_{2}\right)$ which is classified "irritating to the skin" and "severely irritating to the eyes", are in the lowest subcategory of the classification [108]. Finally, the stabilizer components are indicated as "amine complex" and "organic surfactant". These components may not be elaborated on because they are company confidential, hence no specific hazard classification can be given. However, none of these components is classified beyond "corrosive" and "danger to aquatic life" in the lowest subcategory of the classification [108].

During the operation of the Seasalt battery, intermediates are formed as a result of the chemical reactions taking place during charging and discharging. Again, the specifics of the chemical reactions may not be given, however, the main intermediates can be discussed. Firstly, solid (metallic) zinc is formed, which has no hazard classification. Secondly, an aqueous complex of carbon, chloride and bromide $\left(\mathrm{C}-\mathrm{Br}_{x} \mathrm{Cl}_{y}\right)$ is formed. This complex consists of a mixture of components with various numbers and ratios of bromide $(x)$ and chloride $(y)$ (see [121] and [122]). Hence, the exact composition of the complex is not yet known and a conclusive hazard classification can not be given.

In summary, the components used in the final design of the Seasalt battery, as well as the main intermediates, all have a low GHS hazard classification. In other words, these components and intermediates are comparably hazardous to e.g. toilet cleaner, laundry detergent, and drain cleaner, present in most households. Therefore, overall the Seasalt battery can be regarded as environmentally responsible. However, improper disposal of a Seasalt battery still may cause (short term) damage to the environment and health issues for people. Hence a Seasalt battery, like any other battery, should be properly disposed, dismantled and the components should be recycled as much as possible.

\subsubsection{Durable}

The Seasalt battery also should be durable. Here, durable means that the battery should work properly for a long period. Hence, the battery should be resistant against ageing and other degradation, but it also should be resistant to wear and tear.

Ageing

The ageing, or the gradual performance degradation of a battery are the result of complex interrelated phenomena that depend on battery chemistry, design, environment, and the actual operational conditions [67]. It is difficult to account for the environment (in which a battery is used) and the actual operational 
conditions, during the design process of a battery, as these may differ between users and use-cases. Furthermore, designing a battery for one specific use-case may exclude many other possible use-cases. Though, the battery chemistry and physical design are taken into account in the design of a battery, it is still difficult to research the effect of design choices on the ageing of a battery, as the ageing process is gradual and takes place in real time. While it is possible to set up experiments to test the ageing of batteries faster (e.g. by (dis)charging at high currents or voltages, or by testing only partial charge/discharge cycles), these tests themselves can influence the ageing process. Hence effects that take longer to propagate could be overlooked or effects that would not occur during normal usage could be overrepresented.

Therefore, it was decided, during the design process of the Seasalt battery, to perform these ageing tests in real time on small battery prototypes. In Figure 5.1 the relevant parts of one ageing experiment on such a prototype are shown ${ }^{3}$. Note, that the physical properties of the prototype are not exactly the same as the eventual battery, hence there may still be differences between the ageing of this prototype and the eventual design. Note furthermore, that although the electrodes and main components of the electrolyte were all included in the battery prototype, the prototype did not contain all additives as shown in Table 5.1. Therefore, the results of the test displayed in Figure 5.1 only give a (good) indication of the ageing of most components of the Seasalt battery during normal operation.

The results in Figure 5.1 are of an ageing test on a $50 \mathrm{mAh}$ Seasalt battery. A charge/discharge cycle for the battery consisted of charging for one hour with $50 \mathrm{~mA}$ and subsequently discharging for one hour with $50 \mathrm{~mA}$, this cycle was repeated constantly. The voltage in the discharge part of the cycle has a bottom limit of $0.7 \mathrm{~V}$ and if this voltage is reached the rest of the discharge step is skipped and the charge step of the next cycle is started. Although, the test was set to run for a long period, on day 117 the equipment malfunctioned and the test was stopped. At this time approximately 1400 cycles had been completed.

To analyse the results of Figure 5.1 two different round-trip efficiencies are discussed. The first is the current efficiency (Equation 5.12), which is the percentage of charged current (in Ah) that can be discharged in one cycle. The second is the energy-efficiency (Equation 5.1b) which is the percentage of charged energy (in Wh) that can be discharged in one cycle. The energy-efficiency represents the part of the battery capacity that was functionally used during the cycle.

$$
\begin{aligned}
& \text { Current-efficiency }=\frac{\mathrm{A} \mathrm{h}_{\text {discharged }}}{\mathrm{Ah_{ \text {charged } }}} \cdot 100 \% \\
& \text { Energy-efficiency }=\frac{\mathrm{W} \mathrm{h}_{\text {discharged }}}{W h_{\text {charged }}} \cdot 100 \%
\end{aligned}
$$

${ }^{3}$ For the results of the full test results an estimated 35 pages of graphs would be needed (using the layout of Figure 5.1a). 
In Figure 5.1a the voltage during the first 10 cycles of the test are displayed. From the figure it is immediately clear that these cycles are nearly identical. On average $49.4 \mathrm{mAh}$ is charged into the battery, and $46.4 \mathrm{mAh}$ is discharged from the battery. Hence during the first 10 cycles, the battery has a current-efficiency of $94 \%$, or an energy-efficiency of $65.5 \%$. In Figure $5.1 \mathrm{~b}$ the voltage during the last 10 cycles of the test is displayed. The cycles are also nearly identical, but they are clearly different from the first 10 cycles of the test. The charging voltage during the last cycles is much higher than during the first cycles. The difference between highest voltage is approximately $0.7 \mathrm{~V}$ and this is mostly due to the voltage increase immediately at the start of the charging step, (approximately 0.8 $\mathrm{V}$ during the first 10 cycles and approximately $1.2 \mathrm{~V}$ during the last 10 cycles). The efficiencies also are changing, on average per cycle $48.4 \mathrm{mAh}$ is charged into the battery and $35.1 \mathrm{mAh}$ is discharged from the battery. During the last 10 cycles, the battery has a current-efficiency of $72.4 \%$, or an energy-efficiency of $31.3 \%$.

In Figures 5.1c-5.1h, the voltage during six cycles in different weeks in the ageing test is displayed in more detail. These figures indicate a gradual degradation of the charge / discharge cycles, current-efficiency and power-efficiency, as would be expected. However, after approximately 1400 cycles the Seasalt battery still operates at above $50 \%$ of the initial power-efficiency, and above $75 \%$ of the initial current efficiency. Hence the Seasalt battery has not yet failed at this point. In comparison to lead-acid batteries, which tend to fail at around 800 cycles [33], this is significantly better. Furthermore, in comparison to Li-ion batteries, which tend to fail at approximately 2000 cycles [33], this is a bit less, even considering that the ageing test was aborted due to equipment malfunction and not due to battery failure.

\section{Wear and tear}

Another aspect of the design goal of durability is that the battery should be resistant to wear and tear. However, in the selection of the materials for the battery casing, also the third design goal, affordability, should be considered. In most cases, more sturdy and durable materials tend to be more expensive, hence sometimes trade-off's are made between durability and affordability. The design of the cell casing for the Seasalt battery is still an ongoing process, in which many prototypes are built and tested. Here, two different cell casing designs are discussed: Type 1, which gives the most promising results and Type 2, which is used in the practical tests (see Section 5.6). In Figure 5.2 examples of both types of battery casing are displayed.

For both Seasalt battery types the electrolyte and electrodes are those presented in Table 5.1, only the outer casing is different. Cell casing Type 1 (see Figure 5.2a) consists of of a pre-fabricated plastic bag open at one end. The electrodes and separators are placed inside, subsequently the bag is sealed around the electrodes and a filler cap is put in place. The electrolyte is added after the cell is sealed. 


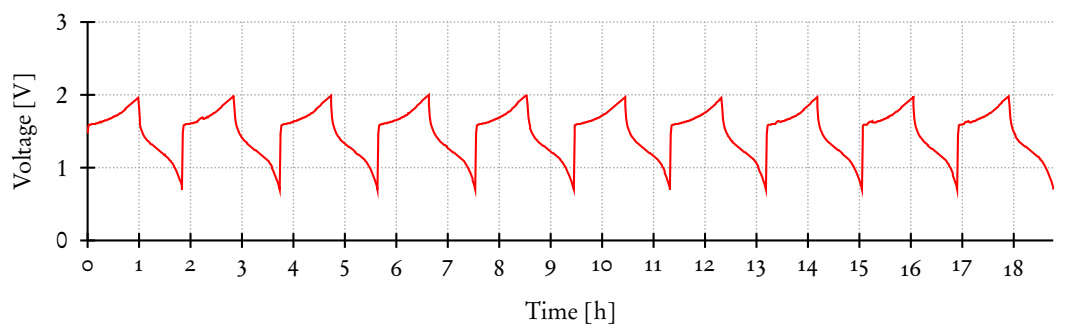

(a) First 10 cycles

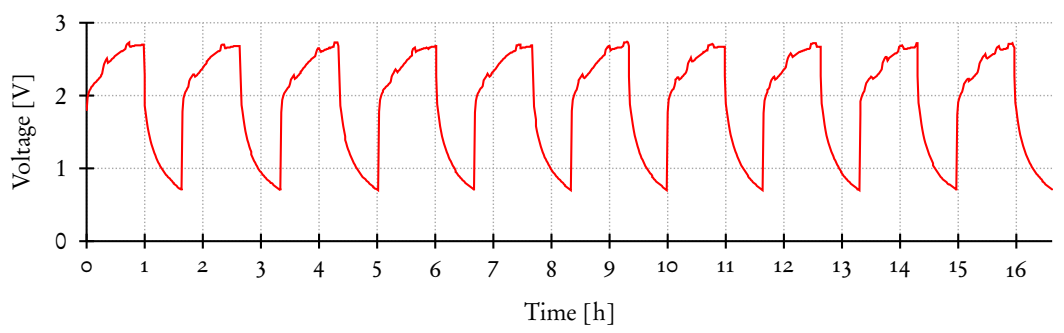

(b) Last 10 cycles

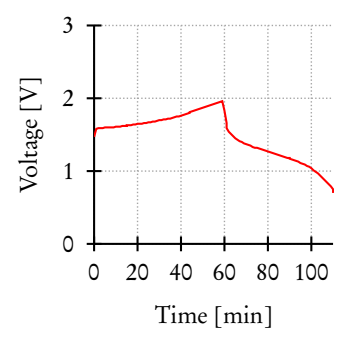

(c) Cycle in week 1

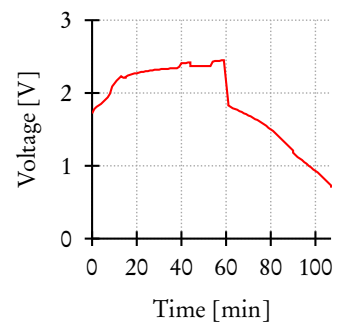

(f) Cycle in week 6

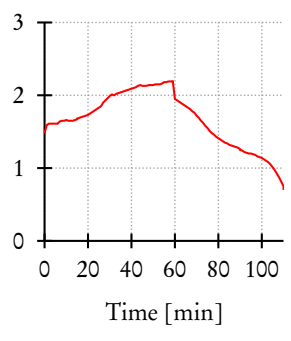

(d) Cycle in week 2

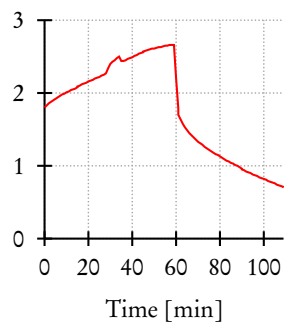

(g) Cycle in week 10

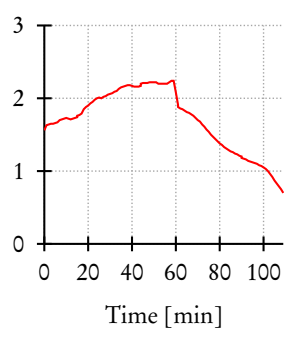

(e) Cycle in week 4

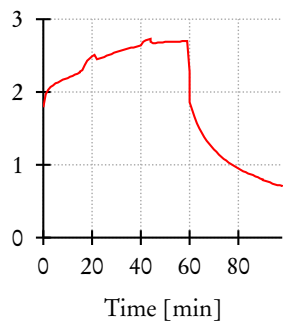

(h) Cycle in week 15

Figure 5.1: Relevant parts of an ageing test on a $50 \mathrm{mAh}$ Seasalt battery prototype. The test consists of constantly repeating cycles of one hour charge with 50 $\mathrm{mA}$ and one hour discharge with $50 \mathrm{~mA}$. Only the first 10 cycles, last 10 cycles and relevant details of the approximately 1400 cycle tests, are displayed. 


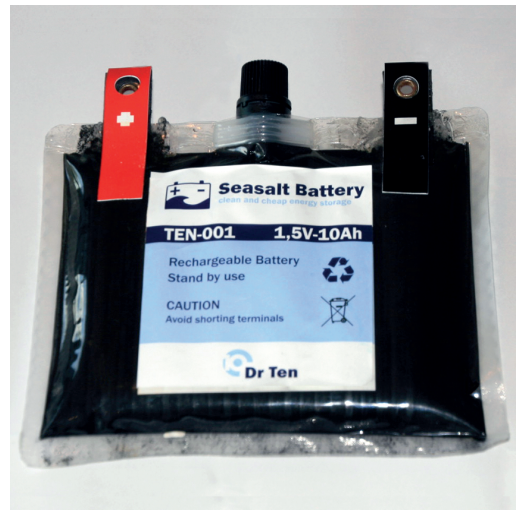

(a) Type 1

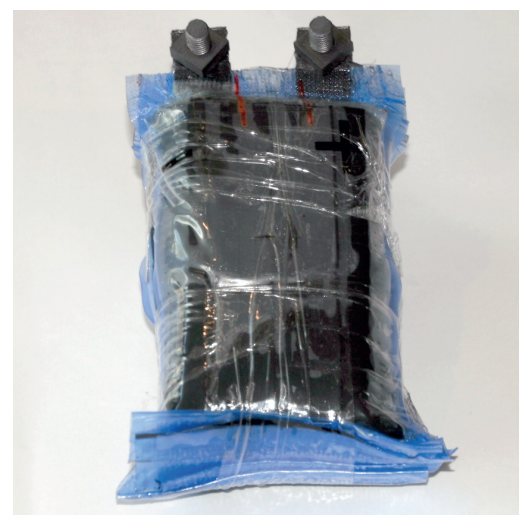

(b) Type 2

Figure 5.2: Examples of Seasalt battery cell casings.

Connections between cells are made using copper wires connected to the graphite electrodes on the outside of the cell.

Although the tests on the operation of the Seasalt battery using this type of cell casing are very promising (see Section 5.4), some of the features of cell casing Type 1 are not practical from a business point of view. The filler cap is an expensive component relative to the rest of the cell. Moreover, the extra operation of adding the electrolyte after the cell is already sealed is a time-consuming and therefore expensive step. The copper wiring is also a relatively expensive part of the design, which adds substantially to the weight of the cell. Lastly the width of this cell design is an issue. Using this design only three cells can be placed next to each other in the desired battery box, while four cells next to each other is better for making specific connections between cells.

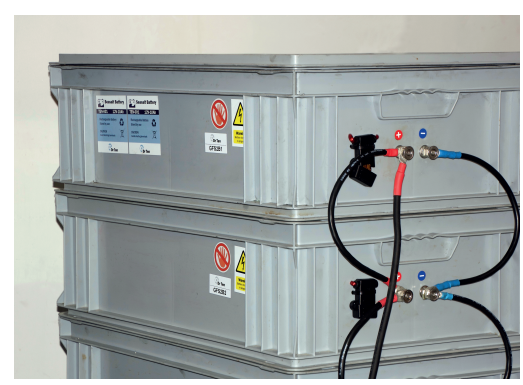

(a) Battery module exterior

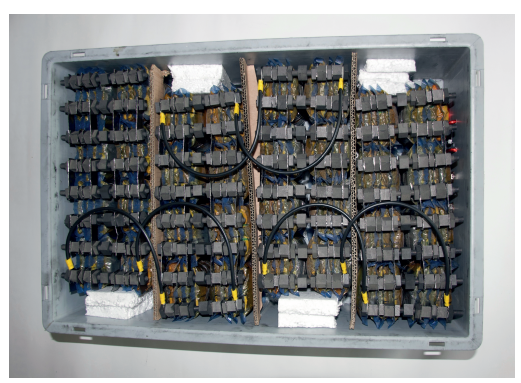

(b) Battery module interior

Figure 5.3: Examples of Seasalt battery modules.

The mentioned specific problems are solved in the design of cell casing Type 
2. However, here some trade-off's are made between quality and cost. The cell width is reduced to enable the placement of four cells next to each other. However, the cell design has influence on the battery performance, and while the performance of the Seasalt battery using cell casing Type 2 (see Section 5.4) are still good, they are somewhat less promising than the performance of the Seasalt battery using cell Type 1 . The copper wire connections are replaced by graphite bolts, which are both less expensive and less heavy. The downside of the graphite bolts is that they are brittle and break easily. However, the cells are eventually placed firmly in a sturdy container, hence this is not a large problem. The assembly process is also changed: in the Type 2 cells the addition of the electrolyte takes place before the cell is completely sealed, hence, no filler cap is needed.

Battery cells of Type 2 are assembled into battery modules, displayed in Figure 5.3. The exterior box (see Figure 5.3a) is a sturdy plastic container, tested to be able to contain the electrolyte if one cell (or even all cells) should rupture. The plus and minus poles are located at the front of each module and connections between battery modules are made using copper wiring. Each battery module is equipped with a circuit breaker for protection. The interior of each battery module (see Figure 5.3b) consists of 128 Type 2 battery cells, connected mostly using graphite bolts. Copper wires are still used where flexible connections are needed. The 128 cells are fitted very tightly into the box, limiting any movement of the cells to prevent damage to the graphite bolts.

\section{$5 \cdot 3 \cdot 3$ In Summary}

The three design goals set for the Seasalt battery, namely that the battery should be 1) environmentally responsible, 2) durable and 3) affordable, have all been met.

- Environmentally responsible: All components that make up the electrolyte or the electrodes are selected to have the lowest possible hazard classification, none of the components are classified beyond Warning, Corrosive or Danger to aquatic life.

- Environmentally responsible: Most components used in the Seasalt battery are abundant and readily available, this also contributes to the affordability of the battery.

- Durable: The Seasalt battery has been demonstrated to retain above $50 \%$ energy-efficiency and above $75 \%$ current-efficiency after approximately 1400 charge / discharge cycles.

- Durable: All components that make up the battery cell casing and outer casing are selected based on high durability, however, some compromises have been made to keep the battery affordable. 


\subsection{Charge \& Discharge behaviour}

In this section the behaviour during charging and discharging of Seasalt batteries is discussed. For this, measurements on two different types of Seasalt batteries are used:

- Type 1: A Type 1 Seasalt battery consists of 5 cells in parallel using cell casing Type 1 (see Figure 5.2a), which results in a battery with a capacity of $2.5 \mathrm{Ah}$ (or $4.5 \mathrm{Wh}$ ) and a charging voltage of around $1.8 \mathrm{~V}$.

- Type 2: A Type 2 Seasalt battery consists of 4 cells in parallel using cell casing Type 2 (see Figure 5.2b), which results in a battery with a capacity of $0.3 \mathrm{Ah}$ (or $0.5 \mathrm{Wh}$ ) and a charging voltage of around $1.8 \mathrm{~V}$.

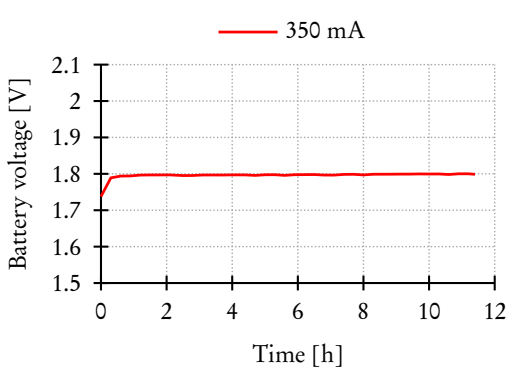

(a) Battery Type 1

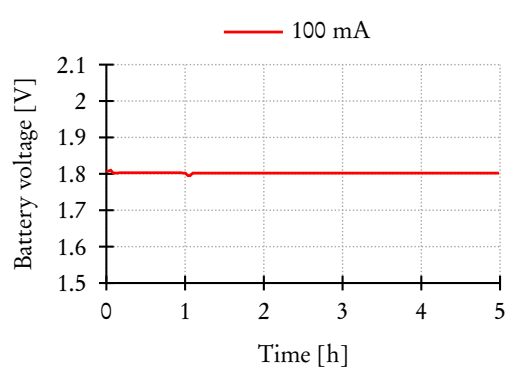

(b) Battery Type 2

Figure 5.4: Voltage during charging of Type 1 and Type 2 Seasalt batteries.

Figure 5.4 shows the voltage during charging of Type 1 and Type 2 Seasalt batteries. The charging behaviour of both battery types looks quite similar. In both

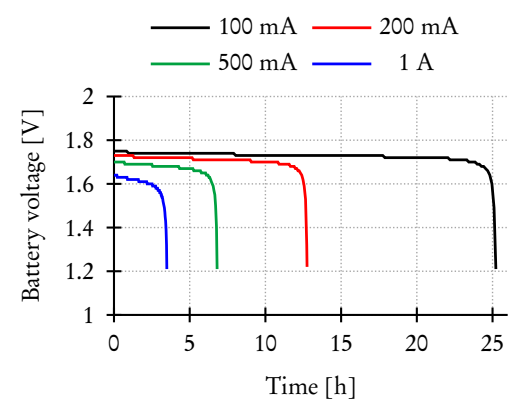

(a) Battery Type 1

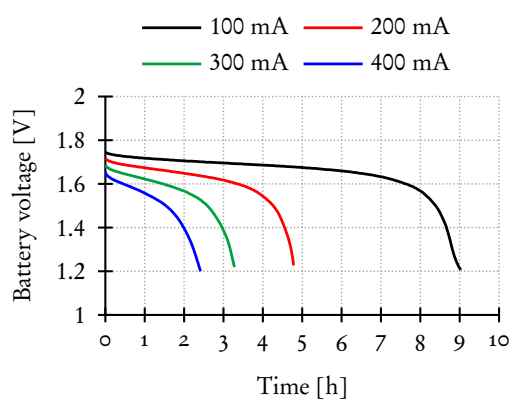

(b) Battery Type 2

Figure 5.5: Voltage during constant current discharging of of Type 1 and Type 2 Seasalt batteries, for varied discharge currents. In each experiment the discharging was stopped at $1.2 \mathrm{~V}$. 
cases, the voltage is constant at $1.8 \mathrm{~V}$ during most of the charging process. This voltage is reached quickly after the charging is started, even if the voltage just before the start of charging is very low. This is very different from the charging behaviour of e.g. Pb-acid or Li-Poly batteries (see Figure 2.6), for which the voltage gradually rises during the charging process. The constant charge voltage (see Figure 5.4b) presents no clear advantages or disadvantages compared to batteries with a rising charge voltage. However, this behaviour leads to a challenge when using of-the-shelf charging equipment, because in this equipment the voltage is usually used as a measure for when the battery is fully charged, i.e. the charging is automatically stopped at a certain voltage, beyond which it is not safe to charge the battery. As the voltage of the Seasalt battery does not change during charging, some other precaution to prevent overcharging must be taken.

Figure 5.5 shows the voltage during discharging of Type 1 and Type 2 Seasalt batteries. As opposed to the charging behaviour, the discharging behaviour of the Seasalt battery is very similar to the discharge behaviour of e.g. Pb-acid or Li-Poly batteries (see Figure 2.5). Both Seasalt battery types show the gradual decline and subsequent steep drop off in voltage during discharge, also present in the discharge behaviour of both Pb-acid or Li-Poly batteries. However, in both types of Seasalt batteries the voltage decline is more gradual than for both other battery types. This is particularly visible for Type 1 Seasalt batteries (see Figure $5.5 \mathrm{a}$ ), where the voltage decline is very gradual and the drop off very sudden and steep. This is an advantage, as during discharge the Seasalt battery delivers a stable voltage, until the battery is almost completely empty.

The envisioned advantages of the Type 1 Seasalt battery over the Type 2 Seasalt battery do not compensate for the fact that it is financially less attractive. Therefore, it has been chosen by the company to use the Type 2 Seasalt battery for production. Hence, these Type 2 Seasalt batteries are used for the lab-scale tests and the practical tests from here on.

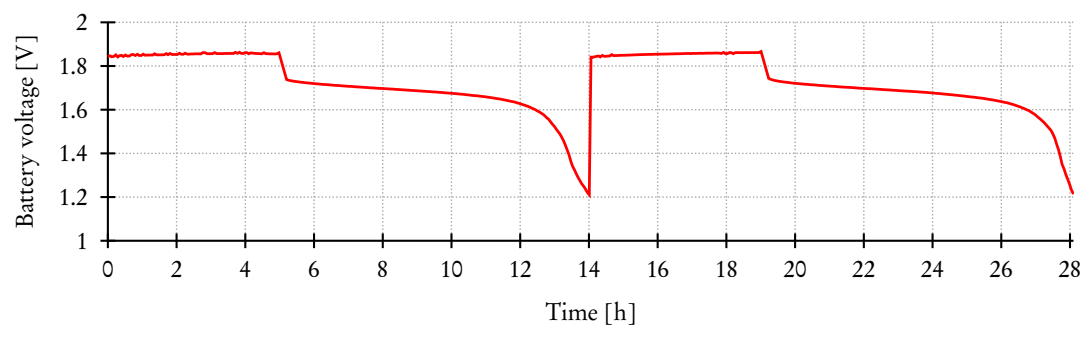

Figure 5.6: Two consecutive constant current charge/discharge cycles of a Type 2 Seasalt battery. The battery was charged with $250 \mathrm{~mA}$ and discharged with 100 $\mathrm{mA}$.

Figure 5.6 shows the measured voltages for two charge/discharge cycles of the Type 2 Seasalt battery. In each cycle the battery was charged with $250 \mathrm{~mA}$ for 5 
hours, and discharged with $100 \mathrm{~mA}$ until a (cut-off) voltage of $1.2 \mathrm{~V}$ was reached. In this case the average current-efficiency (see Equation 5.1a) per cycle is $71.4 \%$ and the average energy-efficiency (see Equation 5.1b) per cycle is $63.3 \%$.

\subsection{State of Charge PRediction}

For batteries, it is useful and important to know and to predict the State of Charge of the battery. Ideally the DiBu-model, as introduced in Chapter 2, is used for this. However, as discussed in Section 5.4 the behaviour of the Seasalt battery during charging is quite different when compared to the behaviour of $\mathrm{Pb}$-acid or Li-Poly batteries during charging steps (for examples see Figures 5.4 and 2.6). Therefore, it is first determined whether or not it is possible to apply the DiBu-model for state of charge prediction of the Seasalt battery.

\subsubsection{Modifications to the DiBu-model}

To emphasize the difference between the behaviour of the Seasalt battery and other batteries (Pb-acid, Li-Poly), in Figure 5.7 five consecutive charge/discharge cycles of the three battery types are displayed ${ }^{4}$. To allow a better comparison between the behaviour, the cycle time is scaled to fit 5 cycles in each graph.
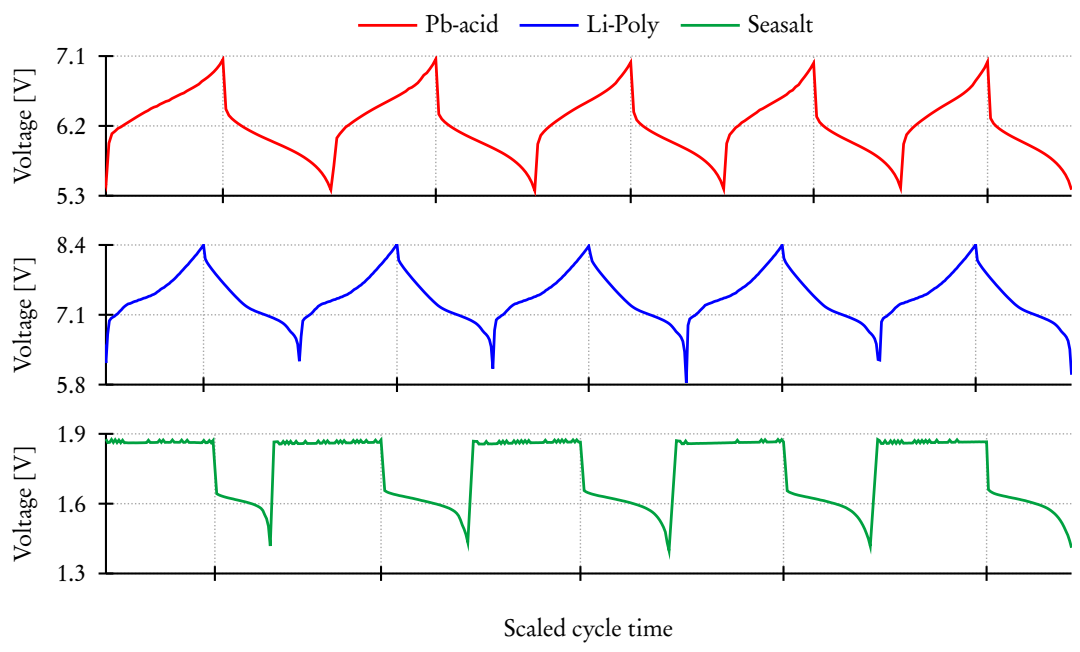

Figure 5.7: Five consecutive charge/discharge cycles for a Pb-acid, Li-Poly and Type 2 Seasalt battery.

From Figure 5.7 it immediately becomes clear that the main difference between the Seasalt battery and the other two batteries is the missing voltage rise during

4The data used for Figure 5.7 was measured by M. De Alcantara Neto [123] 
the charge step. This difference poses a problem when applying the DiBu-model, as the voltage prediction for the charge step (Equation 5.2) does not apply to the Seasalt battery.

$$
U_{t_{j}}=U_{t_{j-1}}+\frac{\bar{I}}{\delta}
$$

As discussed in Section 2.4.2 the equation used to predict the voltage during the charge step, is a linear approximation of the charge behaviour. The slope of this voltage is dependent on the charge current but is also specific for a battery type and capacity. Thus in Equation 5.2 the (implicit) assumption is made that the voltage rises during the charging step. However the voltage of the Seasalt battery does not significantly rise during the charging step. So applying Equation 5.2 with any value for $\delta$ will produce inaccurate voltage predictions which get worse over time. However, simply removing the dependency on the charging current from Equation 5.2 is not possible as the charging voltage is still dependent on the charging current. This relation between voltage and current during the charging step, for two different Seasalt batteries is displayed in Figure 5.8. The measurements indicate that there is a linear relation between the charging current and the resulting voltage.

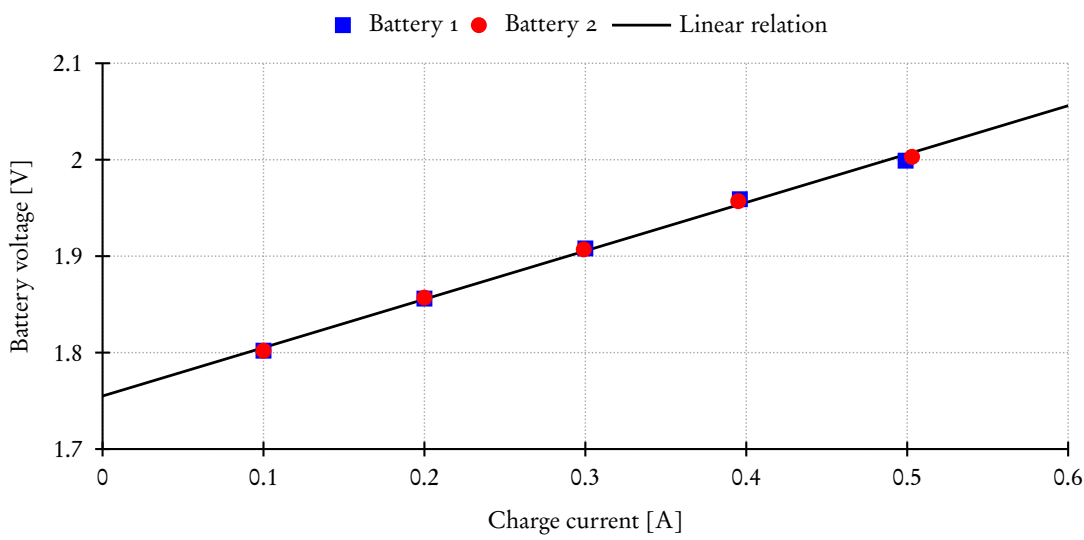

Figure 5.8: Relation between voltage and current during constant current charge of a Type 2 Seasalt battery, for varied charge currents.

The observed linear relation between charging current and resulting voltage displayed in Figure 5.8 can be used to predict the charging voltage needed for the SoC prediction. Concretely, the equation:

$$
U_{t_{j}}=U_{o c p}+\sigma \cdot \bar{I}
$$


is used. In which, $\bar{I}$ is the applied current, $U_{t_{j}}$ the resulting voltage and parameters $\sigma$ and $U_{o c p}$ are battery specific constants, where $U_{o c p}$ is the voltage measured when the battery is idle (open circuit potential). The values for $\sigma$ and $U_{\text {ocp }}$ can be determined from the measurements displayed in Figure 5.8. The other parameters necessary for the SoC prediction with the DiBu-model $(\alpha, \beta$ and $\gamma$ ) are determined in the usual way (see Section 2.4.4). The values for the parameters determined for the used Type 2 Seasalt battery are given in Table 5.2.

Table 5.2: Characteristics and parameters determined for the tested Seasalt batteries.

\begin{tabular}{lc}
\hline & Type 2 Seasalt battery \\
\hline Rated capacity $(\mathrm{Ah})$ & 0,5 \\
Nominal voltage $(\mathrm{V})$ & 1,8 \\
$\alpha(\mathrm{V} / \mathrm{A})$ & $3,927 \times 10^{-4}$ \\
$\beta(-)$ & 0,351 \\
$\gamma(\mathrm{min})$ & 0,998 \\
$\sigma(\mathrm{V} / \mathrm{A})$ & 0,502 \\
$U_{o c p}(\mathrm{~V})$ & 1,755 \\
\hline
\end{tabular}

\subsubsection{Verification of the DiBu-model}

Using the parameters from Table 5.2 and the formulas discussed in Sections 2.5 and 2.6 the DiBu-model is applied to predict the SoC of the Seasalt battery. The used parameters and values are given in Table 5.3.

Initially, the voltage is predicted using Equations 5.3, 2.7, 2.9 and 2.12. The predicted and the measured voltage, for each step is displayed in Figure 5.9. As was the case with other battery types, the voltage prediction is not very

Table 5.3: The charge, discharge and idle steps used in the experiments described in Figures 5.9 and 5.10.

\begin{tabular}{clccc}
\hline Step \# & Type & Current $(\mathbf{m A})$ & Length $(\mathrm{min})$ & Total $(\mathrm{min})$ \\
\hline 1 & Charge & 120 & 100 & 120 \\
2 & Discharge & 30 & -200 & 150 \\
3 & Charge & 120 & 100 & 270 \\
4 & Discharge & 150 & -100 & 420 \\
5 & Idle & 30 & 0 & 450 \\
6 & Charge & 180 & 50 & 630 \\
7 & Charge & 30 & 200 & 660 \\
8 & Discharge & 180 & -50 & 840 \\
9 & Idle & 60 & 0 & 900 \\
10 & Charge & 120 & 100 & 1020 \\
11 & Discharge & 90 & -100 & 1110 \\
\hline
\end{tabular}


accurate, but the general trend of the voltage is predicted correctly. The difference between the measured and predicted voltage is smallest during the charge steps and the difference remains generally below $1 \%$ of the total voltage. However, during discharging steps the difference rises as well, with the biggest differences occurring at the end of long discharge steps, like for example at the end of Step $8(10.2 \%)$ and Step $11(15.2 \%)$. However, as mentioned before, accurate voltage predictions are not the main goal, as these large differences may have only a minor impact on the accuracy of the SoC prediction.

Subsequently the SoC for the Seasalt battery is predicted. The SoC calculated from measurements (SoC ${ }^{\text {meas }}$ ) and the SoC predicted using the $\mathrm{DiBu}$-model $\left(\mathrm{SoC}^{\mathrm{DiBu}}\right)$ are displayed in Figure 5.10. From this figure it is immediately clear that the prediction of the SoC for the Seasalt battery closely follows the SoC calculated from the measurements. The difference between $\mathrm{SoC}^{\text {meas }}$ and SoC ${ }^{\mathrm{DiBu}}$ is at most $3.6 \%$, which occurs at the end of Step 11, (discharge). This difference between the SoC ${ }^{\text {meas }}$ and SoC ${ }^{\mathrm{DiBu}}$ also peaks (to $3.1 \%$ ) at the end of Step 7 (charge) but generally remains around $2 \%$. The difference between the SoC $C^{\text {DiBu }}$ and $\mathrm{SoC}^{\text {meas }}$ for all steps has been included in Table B.7 in the appendix.
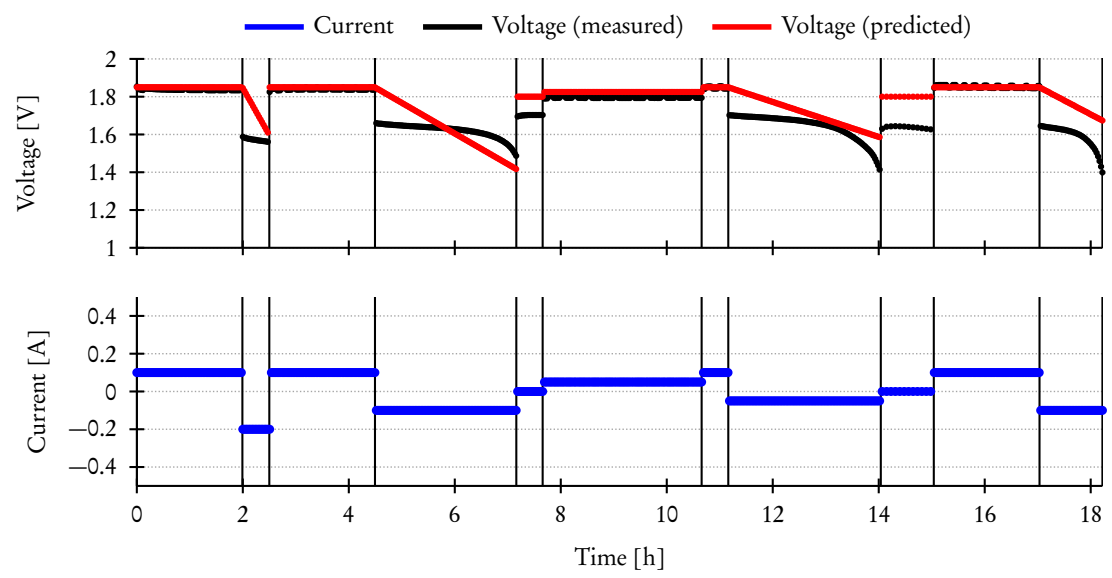

Figure 5.9: The applied current and resulting voltage during various charge and discharge steps on a Type 2 Seasalt battery. The black vertical lines represent the moment of step-change.

The improvements to the DiBu-model, as discussed in Section 2.6.2 (calibrating SoC ${ }_{t}$ and $\mathrm{U}_{t}$ after each discharge step) were also applied to the SoC prediction for the Seasalt battery, the resulting predictions are also displayed in Figure 5.10. The difference between $S_{0} C^{\text {meas }}$ and $S_{o} C^{D i B u}$ for the improved prediction is generally below $1.5 \%$, which is a slight improvement. However, the largest difference between SoC ${ }^{\mathrm{DiBu}}$ and $\mathrm{SoC}^{\text {meas }}$ is now $4.1 \%$ at the end of Step 8 and $3.4 \%$ at the end of Step 4, which is a slight deterioration. Hence over-all the improvements, as discussed in Section 2.6.2 are not that beneficial in this case. 
This can be attributed to the modified equation for the prediction of the voltage during the charge step. In the new equation the predicted voltage is independent of a previous voltage, hence, the effect of a re-calibration of the voltage is negated when a charge step is started, diminishing the over-all effect of the re-calibration.

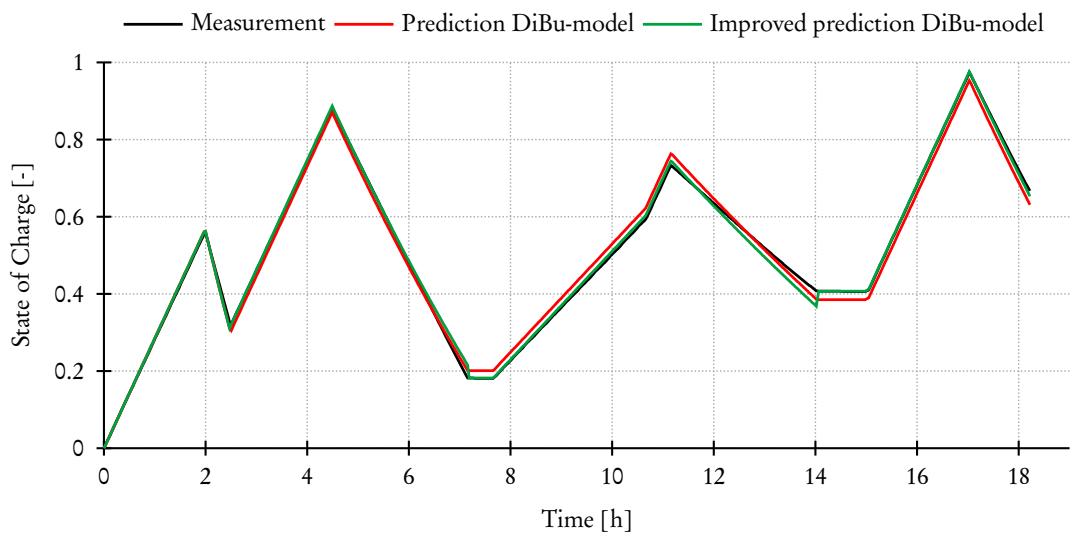

Figure 5.10: State of Charge of a Type 2 Seasalt battery during various charge and discharge steps, measured and predicted using the DiBu-model.

\section{$5 \cdot 5 \cdot 3$ IN CONCLUSION}

From the results of experiments using the Type 2 Seasalt batteries, shown in Figures 5.9 and 5.10 it can be concluded that:

- The DiBu-model can only be applied to Seasalt Batteries when a modified equation for the charge steps is used.

- Using the DiBu-model (with a modified charge step equation), the SoC can be predicted accurately, where the difference between $\mathrm{SoC}^{\mathrm{DiBu}}$ and SoC ${ }^{\text {meas }}$ is generally around $2 \%$.

- Applying the improvements to the DiBu-model suggested in Section 2.6.2, the SoC can be predicted accurately, where the difference between SoC ${ }^{\mathrm{DiBu}}$ and $\mathrm{SoC}^{\text {meas }}$ is generally $\leq 1.5 \%$.

- Over-all, since the SoC predictions were already quite accurate, the improvements are not very beneficial in this case.

\subsection{Practical implementation of the Seasalt battery}

In this section the practical implementation of Seasalt batteries in the Veldegge neighbourhood in Heeten, the Netherlands, as part of the Gridflex project [26], is discussed. The main goal of the Gridflex project is to develop a business-case for an energy market at the local level, including a reproducible market-model 
with benefits for the society and the environment. To achieve this goal, financial incentives via price mechanisms (e.g. the mechanism presented in [42]) that exploit the grid flexibility are used. Furthermore, Seasalt batteries are deployed in the neighbourhood to create flexibility in the local microgrid.

\subsubsection{The Gridflex PROJECT}

The Veldegge neighbourhood consists of 49 houses, all of which participate in the Gridflex project. Some of the houses (roughly half) are already equipped with PVpanels and 19 houses will be equipped with batteries. The electricity grid in the neighbourhood is treated as a microgrid which is connected via one transformer to the national grid. The level of the highest power peak (demand or supply) at the neighbourhood transformer is used by the grid operator to determine the costs of connecting the neighbourhood to the national grid. Hereby, a higher peak leads to higher costs. Hence, the neighbourhood can reduce its grid connection costs when the highest power peak at the transformer is lowered. This regulation is the financial incentive that motivates the inhabitants of the Veldegge neighbourhood to actively participate in the Gridflex project.

In all houses, data on electricity demand and production is measured and communicated to a control unit. This data is used, in combination with e.g. data from the neighbourhood transformer and weather predictions, as input for a simulation in DEMKit (see Section 4.2.2 and [20]) to predict the future energy demand and production (by the PV-panels) of the neighbourhood. This prediction is then used to determine when the batteries should be charged or discharged to achieve power profiles following the used incentive scheme. Or more concrete to achieve lower power peaks at the neighbourhood transformer. For this, steering signals are sent directly from the control unit to the inverter to perform the desired operation of the battery.

Furthermore, the inhabitants of the Veldegge neighbourhood are informed (via an app on their mobile phone) on if, when and how they should be active to lower the highest power peak at the transformer, e.g. limit electricity usage when there is already a high electricity demand, or using an extra electric appliance, such as charging an EV, when there is high electricity production by the PVpanels.

\subsubsection{BATTERY SYSTEM SETUP}

The battery systems deployed in the Veldegge neighbourhood are designed to enable the remote management of the Seasalt batteries, but also to measure the electricity usage (demand and production) of the household where the battery is placed. The actual battery systems, including the inverter and peripheral equipment are displayed in Figure 5.11.

To make the aforementioned operations possible, the battery system includes multiple devices apart from a $2 \mathrm{kWh}, 24 \mathrm{~V}$ Seasalt battery. A schematic represen- 


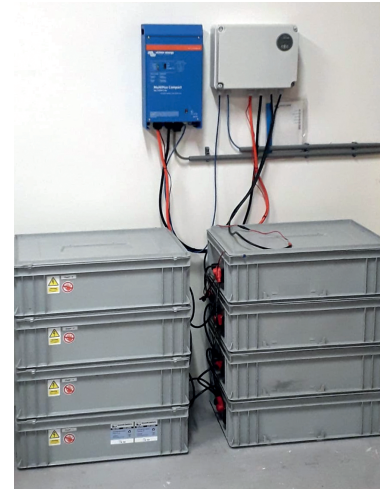

(a) Battery system.

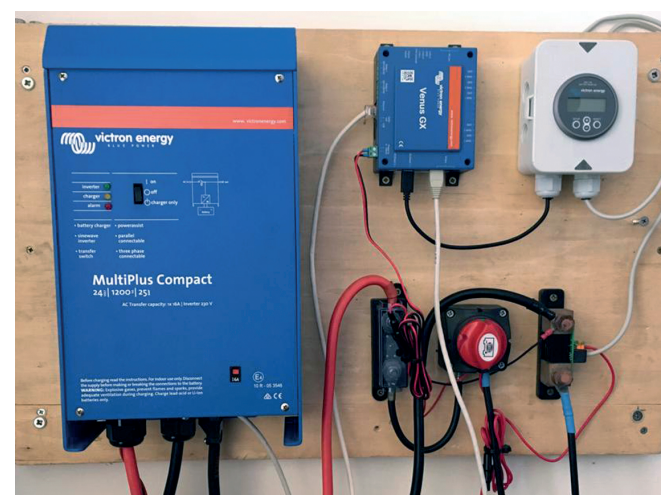

(b) Management and control equipment.

Figure 5.11: The battery system and management and control equipment used in the Veldegge neighbourhood. Note, that the equipment in (b) is especially arranged for display purposes; in practical setups all equipment, except the inverter, is located in the gray box displayed in (a).

tation of the battery system deployed in the Veldegge neighbourhood is displayed in Figure 5.12. Firstly, a Victron Multiplus inverter (1) is used to convert the electricity between $24 \mathrm{~V}$ at the battery side and $230 \mathrm{~V}$ at the microgrid side. Next, a Victron Venus inverter manager (2) is used to enable remote control of the Victron Multiplus via the internet. A Victron BMV device (3) is added to display e.g. the battery current and voltage (measured via a shunt) for the user. This device is added for user comfort only, the measurements are not actually used in the control. The energy management system (4) or EMS is used to gather data from the Victron Multiplus and the Smart-meter (5), and to relay this data to the server (6) running the DEMKit simulator located at the University of Twente. The EMS is also used to relay steering signals from the DEMKit simulator back to the Victron Venus, which in turn instructs the Victron Multiplus to perform the desired operations. Additionally, the inhabitants can access the data gathered by the EMS in their own house via an app on their mobile phone.

\subsubsection{Results}

The Gridflex project is currently still ongoing, therefore only preliminary results are presented for the parts of the research that have already been completed. At this time, not all batteries are already deployed in the Veldegge neighbourhood and the steering of the batteries is not yet functioning optimally. However, preliminary results relating to the behaviour and performance of the Seasalt batteries are already available and are presented in Figure 5.13. This figure shows the performance of a $2 \mathrm{kWh}$ Seasalt battery for two different target power profiles. In both tests the battery must deliver the power demand of the target power 


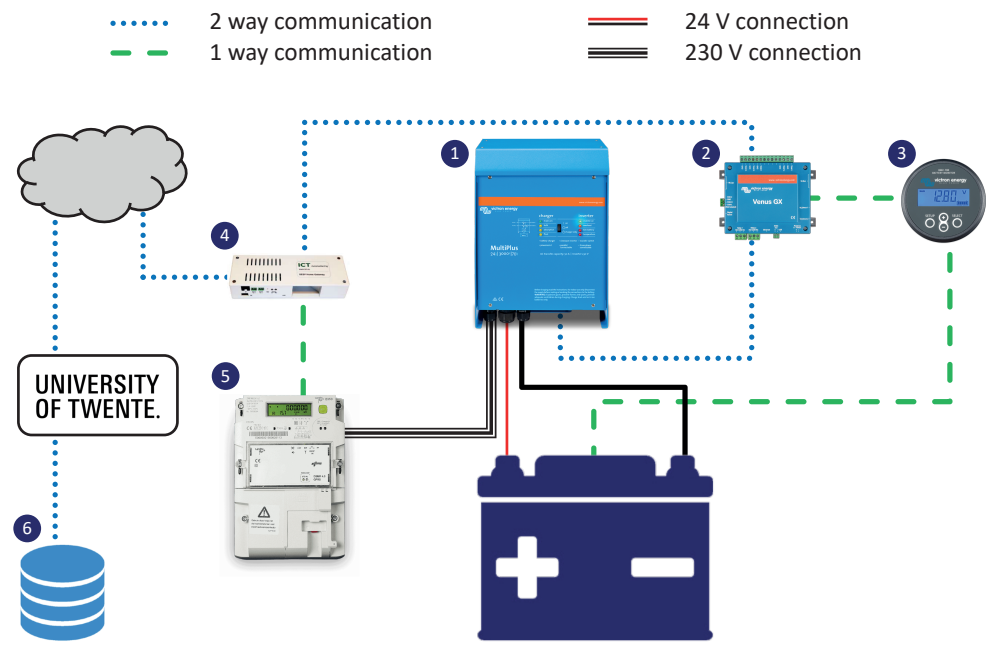

Figure 5.12: Schematic representation of the battery system used in the Veldegge neighbourhood, next to the battery the system includes: 1) Inverter, 2) Inverter manager, 3) Current / Voltage measurement device and display, 4) Energy management system, 5) Smart-meter, 6) Server running DEMKit, located at the University of Twente.

profile. Note, that positive values indicate a power demand from the battery and negative values indicate a power flow to the battery.

In the first test (see Figure 5.13a) a block profile is applied to the battery, i.e. the battery is charged and discharged repeatedly. In this test the battery meets the demand during the first four cycles, hence in these cycles it performs as expected. However, in the discharge part of the last two cycles the battery delivers at some time periods less power as demanded.

This is attributed to the interaction between the battery and the inverter. The Victron Multiplus inverter is designed to operate with Pb-acid and Li-ion batteries, but not with Seasalt batteries. As previously mentioned, the behaviour of Seasalt batteries is different as compared to the behaviour of $\mathrm{Pb}$-acid and $\mathrm{Li}$-ion batteries (see Figure 5.7). This has some unexpected consequences. Sometimes the inverter perceives the battery as empty (or completely discharged) while in reality the battery is not empty. This results in unexpected and (sometimes) unpredictable behaviour. For example, the battery is discharged with less power than desired, or the battery is being charged when it is already at full capacity. This problem can be considered mostly as software-related and has to be solved in the future.

During the second test (see Figure 5.13b) this problem did not occur. In this case 


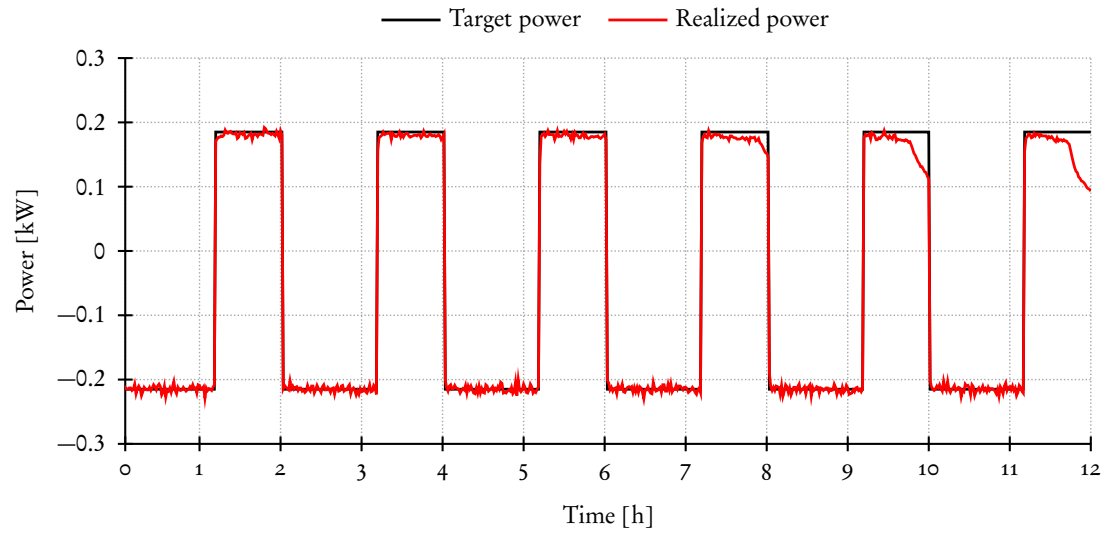

(a) Block-profile.

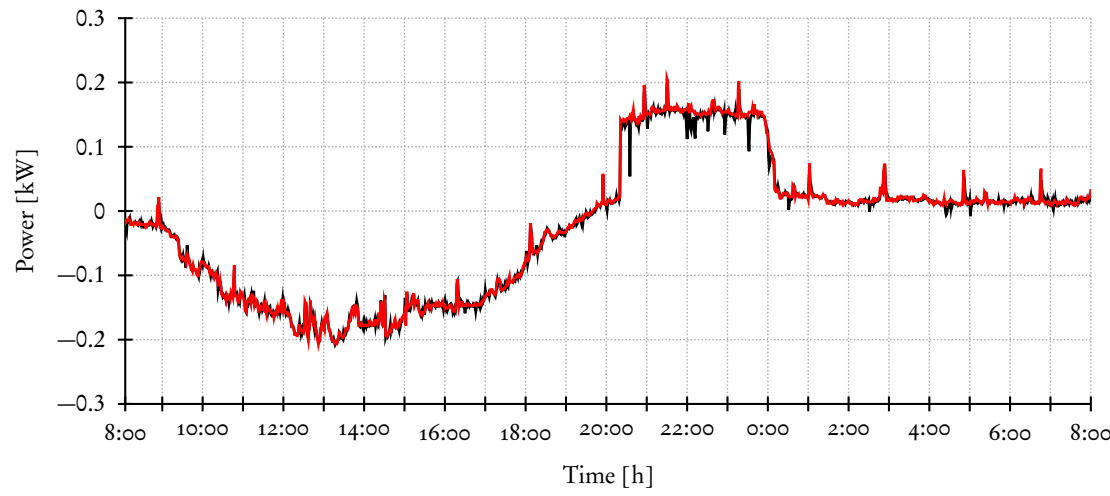

(b) Profile of a household with PV-panels and an electric vehicle (scaled down to a maximum demand and supply of $200 \mathrm{~W}$ ).

Figure 5.13: Comparison of the target power profile and realized power profile of a $2 \mathrm{kWh}$ battery, for different profiles

the target profile is related to the measured power profile during one day in the summer of one of the houses in the Veldegge neighbourhood, scaled down to maximum power peaks of $200 \mathrm{~W}$. The stated goal for the battery is to store all excess electricity generated in the house, and meet all electricity demands not met by the generation. This requested profile is followed precisely, hence the battery performed as expected.

\subsubsection{REMAining CHALLENGES}

The practical implementation of the Seasalt battery in the Veldegge neighbourhood uncovered some unforeseen challenges that complicate the deployment of 
the Seasalt battery. Most of these challenges relate to the fact that of-the-shelf inverter technology is not designed to operate with Seasalt batteries. In the following, these challenges are discussed in relation to of-the-shelf inverters for 24 $\mathrm{V}$ batteries, which are used in the Gridflex project. However, similar challenges exist for other inverters (e.g. $12 \mathrm{~V}$ ).

- There are hardware incompatibilities between the Seasalt battery and the inverters. As inverters are mostly designed to operate with $\mathrm{Pb}$-acid and Li-ion batteries, the voltage bandwidth that inverter can handle is mostly between $20 \mathrm{~V}$ and $30 \mathrm{~V}$. A Seasalt battery, designed to operate at $24 \mathrm{~V}$ is ideally discharged to $16 \mathrm{~V}$. Hence, discharging a Seasalt battery with of -theshelf inverter technology is very difficult, as it usually does not operate below $20 \mathrm{~V}$.

- There are software incompatibilities. Most inverters have some form of smart regulation of the charge and discharge process of different batteries, to prevent damage to the batteries or to the inverter. However, this software is not designed with Seasalt batteries in mind, and often is incompatible with the behaviour of Seasalt batteries. In the Gridflex project, an adaptation was made to the software used to operate $\mathrm{Pb}$-acid-gel batteries, as this is closest to what is needed to operate a Seasalt battery. However, this workaround is still far from ideal and results in (sometimes severe) problems.

The research into solutions for the observed challenges (e.g. designing an inverter for the Seasalt battery and rewriting the software of an existing inverter) is still an ongoing process.

\subsection{Conclusions}

The Seasalt battery can be considered as an alternative battery for stationary applications and is designed with three goals in mind. The Seasalt battery should be 1) Environmentally responsible, 2) Durable and 3) Affordable. To satisfy the goal of environmental responsibility, none of the components used in the electrolyte or the electrodes has a GHS hazard classification beyond beyond Warning, Corrosive or Danger to aquatic life. Although these signal words sound ominous, these classifications are also given to dishwasher soap, toilet cleaner and laundry detergent, all present in the average kitchen sink. The durability of a prototype Seasalt battery has been demonstrated by performing approximately 1400 consecutive charge/discharge cycles. Although clear signs of ageing and degradation are present after these 1400 cycles, the Seasalt battery still operates at above $5^{\circ}$ $\%$ of the initial energy-efficiency, and above $75 \%$ of the initial current-efficiency. The battery casing itself is a trade-off between durability and affordability.

The Seasalt battery behaves during charging somewhat different compared to e.g. $\mathrm{Pb}$-acid and Li-Poly batteries. The voltage of a Seasalt battery during charging remains constant (at $1.8 \mathrm{~V}$ per cell) whereas voltage of $\mathrm{Pb}$-acid and Li-Poly batteries 
gradually rises during charging. This is neither an advantage nor a disadvantage. However, there is an operational challenge, because in most batteries the gradual voltage rise is used by the charging equipment as a measure for when a battery is fully charged. This can not be done with a Seasalt battery, as the charging voltage is almost constant.

The Seasalt battery behaves during discharging largely similar compared to e.g. $\mathrm{Pb}$-acid and Li-Poly batteries. The voltage gradually declines until the battery is nearly discharged, then the voltage drops rapidly. The voltage of a Seasalt battery declines slower than comparable $\mathrm{Pb}$-acid and Li-Poly batteries, whereas the change to rapid decline is more sudden. This is an advantage as the battery delivers a more stable voltage until it is almost completely discharged.

In a further step, the DiBu-model was applied to the Seasalt battery. However, because the behaviour of the Seasalt battery during charging is different from other batteries, it was determined that the charging equation of the DiBu-model does not apply to the Seasalt battery. Therefore the DiBu-model can only be applied to Seasalt Batteries when a modified equation for the charge steps is used. It is demonstrated that using the modified DiBu-model to predict the SoC of a Seasalt battery, results in an accurately predicted SoC, where the the difference between SoC ${ }^{\text {DiBu }}$ and $\mathrm{SoC}^{\text {meas }}$ is generally around $2 \%$.

The Seasalt battery is also tested in a practical setting in the Veldegge neighbourhood, as part of the Gridflex project. In this project multiple $24 \mathrm{~V}$ versions of the Seasalt battery are deployed throughout the neighbourhood. Although challenges remain that make deployment of the Seasalt battery in a practical setting difficult, the deployed batteries perform largely as expected.

On the whole, the Seasalt battery is a promising battery for stationary applications. Although it is currently not the best battery in terms of volume/capacity or weight/capacity ratios, it is definitely a frontrunner in terms of environmental responsibility and durability. 


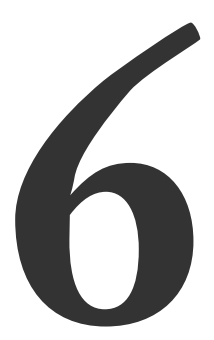

\title{
REDUCTION OF DENDRITE FORMATION AT THE ANODE OF THE SEASAlt BATtery
}

\begin{abstract}
AвSTRACT - Dendrite formation poses serious problems in the operation of zinc-based batteries like the Seasalt battery. Electrode material and electrolyte composition are known to have an influence on the dendrite formation. In this chapter possible solutions for the reduction of dendrite formation at the anode of a zinc-based battery are studied. The electrochemical behaviour of various electrode materials and electrolyte compositions is researched. It is observed that the tested electrode materials have no significant impact on the reaction at the anode. However, significant reduction in dendrite formation are observed at various electrode materials. The largest reduction in dendrite formation is observed when SGL bipolar graphite is used as electrode material. Furthermore, using several analysis methods (CV, EIS, SEM) it is observed that the addition of low concentrations $(\sim 10 \%$ of the main component concentration) of certain additives $\left(\mathrm{MgBr}_{2}, \mathrm{MnSO}_{4}\right)$ to the electrolyte has no significant impact on the electrolyte reaction at the anode, but prevents the formation of dendrites. The changes in substrate material and electrolyte additive do not have significant influence on the over-all performance of the battery.
\end{abstract}

Parts of this chapter have been previously published in [H:9]. 


\subsection{INTRODUCTION}

One of the challenges in the development of the Seasalt battery is the formation of dendrites at the anode. Dendrite formation is a well known problem for zinc-based batteries in general $[115,124]$. The formation of dendrites at the anode may cause ageing, reduced storage capacity and short-circuiting of the battery [67]. An example of dendrites formed during testing of a $\mathrm{ZnBr}_{2}$ based electrochemical cell is shown in Figure 6.1. In this case the deposited zinc forms a brittle "Christmas tree" -like structure at the anode. If this structure continues to grow, eventually it could reach the cathode, causing a short-circuit. If the structure fractures from the anode, the broken part no longer takes part in the electrochemical reaction and as a result the cell-capacity is diminished.

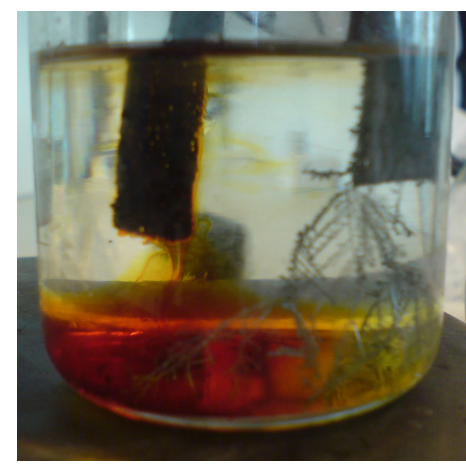

Figure 6.1: The formation of dendrites on the anode of a zinc based battery.

The deposition behaviour is susceptible to changes in various conditions like $\mathrm{pH}$, temperature and current density $[125,126]$, and can be influenced using various techniques. Fukami et al. $[127,128]$ report that the application of electrochemical oscillations during zinc deposition yields wafer-like structures rather than dendrites. Shitanda et al. [129] report that creating a dot-pattern on the substrate surface at the nano-level yields dendrites only where the dots are located on the substrate surface, while Koda et al. [130] note that dendrite formation can be suppressed if deposition takes place within nanopores of a given substrate. Gomes et al. $[131,132]$ state that by the addition of certain surfactants ${ }^{1}$ it is possible to deposit zinc with a different preferred orientation, crystal shape (needles, pyramids, cauliflowers) and size. However, these solutions are impractical for application in a battery because they would either increase the costs of such a battery dramatically, or severely influence the overall behaviour of the battery. Thus different, more practical means of influencing the deposition behaviour have to be applied.

${ }^{1} \mathrm{~A}$ surfactant is a special class of molecule, which have the tendency to preferentially reside at the interface of a polar fluid (e.g. water) and a non-polar fluid (e.g. oil), surfactants also have the tendency to modify surface properties [133]. 
The influence of the substrate on the deposition behaviour of zinc has been studied widely. Various substrate materials such as steel [134], platinum [135], magnesium [136], titanium [137], glassy carbon and graphite [138] have been researched. The common conclusion in these studies is that the composition of the substrate is of vital importance to the zinc-deposition behaviour. It is also concluded that the surface preparation of a substrate can influence the zinc deposition behaviour [139].

The addition of a second depositing material, or co-depositor is also known to have an effect on the deposition of zinc. The co-depositor material should "interfere" with the normal crystallization process of zinc in such a way that structures other than dendrites are formed during deposition. In this case, the cation of the co-depositor is built into the crystal structure made up by the $\mathrm{Zn}^{2+}$ ions altering the overall crystal structure. Several compounds with various cations suitable for co-deposition with zinc have already been tested and described; e.g. nickel, cobalt, iron [140, 141], copper [142] and calcium [143]. The effects of polar additives acetonitrile, ethylenediamine and ammonia were explored by Abbott et al. [144], while the effects of various organic additives have been researched by Li et al. [145] and Ortiz et al. [146]. The preliminary investigation of the behaviour of various additives conducted at Dr Ten B.V., reproducing and adapting experiments described in [140-146], however, did not yield satisfactory results. It was concluded that compounds containing nickel or aluminium severely reduced the deposition reaction on the anode, thereby reducing the energy storage capacity. Furthermore, it was observed that compounds containing calcium limited the reversibility of the deposition at the anode, reducing the charge/discharge cycle-life. Moreover, it was also observed that compounds containing iron or polar additives negatively influenced the reactions at the cathode. However, additives containing manganese or magnesium showed the most promising results, as these were observed to have only limited influence on the reactions at the electrodes.

In this chapter possible solutions to the problem of dendrite formation at the cathode of a zinc-based secondary battery are explored. Firstly, in Section 6.2 the used methods and techniques are outlined. In Section 6.3 the main results of this exploration are discussed. For this, first in Subsection 6.3.1 a reference condition to which the results of all subsequent experiments are compared, is defined. Afterwards, in Subsection 6.3.2 the influence of various substrates on the dendrite formation is investigated and in Subsection 6.3.3 the influence of several additives containing magnesium and manganese ions, that were observed to have little influence on the reaction at the electrodes, is considered. Finally in Subsection 6.3.4 the optimal combination of substrate and additive is explored, the surface of the deposited zinc layers is analysed using Scanning Electron Microscopy and the difference in electrochemical behaviour between the reference condition and the optimal combination of substrate and additive is explored using Electrochemical Impedance Spectroscopy. The conclusions are presented in Section 6.4. 


\subsection{MATERiAls AND METHODS}

The following equipment was used for the experiments:

- The Cyclic Voltammetry (CV) and Chrono-Amperomtery (CA) experiments were conducted on a Metrohm Autolab PGSTAT101 potentiostat, at room temperature, ambient pressure, with a scanrate of $100 \mathrm{mV} / \mathrm{s}$ and using a $\mathrm{Ag} / \mathrm{AgCl}$ reference electrode, obtained from the Metrohm company.

- The electrode surface morphology was analyzed using a standard optical microscope.

- The Scanning Electron Microscopy (SEM) images were taken using a JEOL 1610 LA scanning electron microscope.

- The Electrochemical Impedance Spectroscopy (EIS) measurements were conducted using a $\mathrm{CH}$ Instruments $600 \mathrm{E}$ electrochemical analyser. The EIS experiments were conducted at room temperature and ambient pressure, within a Faraday cage, using a $\mathrm{Ag} / \mathrm{AgCl}$ reference electrode, obtained from the Metrohm company. The EIS measurements were analysed using the EQUIVCRT method and software, developed by Boukamp [147, 148].

In each experiment, the counter-electrode was a standard graphite plate while the working electrode material was varied. Both plates were partially submerged in the electrolyte, making the effective area of each electrode $1 \mathrm{~cm}^{2}$. In all experiments, an excess of electrolyte was used to make sure that absence of electrolyte could never be the limiting factor in the deposition. Unless specifically mentioned, all chemicals $\left(\mathrm{ZnBr}_{2}, \mathrm{MgBr}_{2}, \mathrm{MnSO}_{4}\right.$, etc.) were of trace metals basis grade (purity 99.999\%) and were obtained from the Sigma-Aldrich corporation. The electrode materials were obtained from SGL graphites SE.

\subsection{Results and Discussion}

As the main goal of this work is to achieve a reduction in dendrite formation, i.e. to show changes in zinc deposition behaviour, first the reference to which these changes or reductions are compared has to be precisely specified. All further achieved results are compared to the conditions and results of this reference experiment. Therefore, in Subsection 6.3.1 this reference experiment is discussed and, subsequently, in the following subsections possible changes and improvements are given.

\subsubsection{REFERENCE CONDITION}

In the reference experiment dendrite formation occurs as shown in Figure 6.1. The electrolyte used was a $1 \mathrm{M} \mathrm{ZnBr}_{2}$ (aq) solution and this is referred to as standard electrolyte. The anode (or substrate) was a graphite-coated iron film and 
this electrode material is referred to as standard graphite. The iron film is completely encased by the graphite layer, so the core never comes into contact with the electrolyte. Furthermore the experiments were conducted at atmospheric pressure and ambient temperature, with a $\mathrm{Ag} / \mathrm{AgCl}$ reference electrode, these are referred to as reference conditions. For the deposition experiments a potential of $-1.3 \mathrm{~V}$ was chosen, since at this potential the zinc deposition occurs sufficiently fast to be observed visually during the experiment, while gas evolution at the anode is not observed at this potential. The resulting deposited zinc-layer for a deposition under these reference conditions ( 1 hour at $-1.3 \mathrm{~V}$ ) is displayed in Figure 6.2a. It is clear from visual inspection, that small dendrites have already formed on the edges of the electrode at the end of this 1 hour experiment.

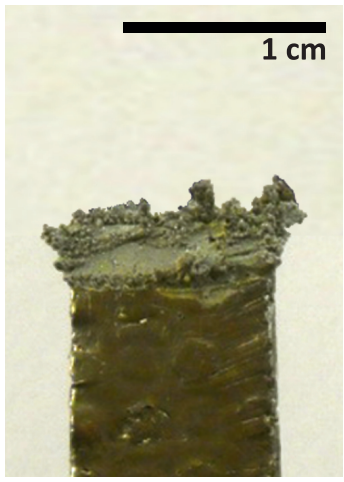

(a)
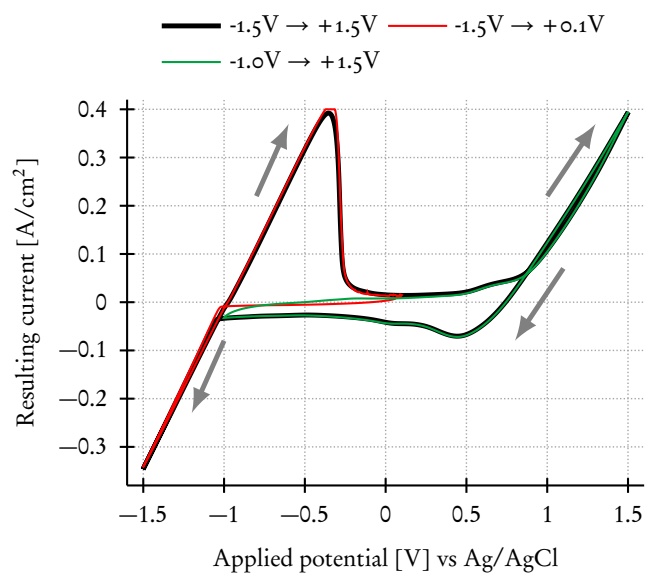

(b)

Figure 6.2: (a) The morphology of a zinc layer deposited at -1.3 $V$ for 1 hour on standard graphite from standard electrolyte. (b) Voltammogram for the reference conditions for varied scan ranges.

In the following subsections the electrochemical behaviour of various substrate / electrolyte combinations is investigated using cyclic voltammetry. The potential range, where zinc deposition at the anode and its counter reaction at the cathode are likely to occur, is scanned, and the resulting current is recorded. The resulting voltammograms are then compared to the reference condition. If the differences between the voltammograms for the two cases are small, the electrochemical behaviour of the compared electrode / electrolyte combinations is similar. As it may occur that the reaction at the cathode has an influence on the reaction at the anode and vice versa, it is tested if this is the case for the zinc deposition reaction. For this, the electrochemical behaviour of standard graphite and $1 \mathrm{M} \mathrm{ZnBr}_{2}$ over different scan ranges is investigated. The corresponding voltammograms are shown in Figure 6.2b. In the anode range $(-1.5 \mathrm{~V}$ to $1 \mathrm{~V})$ the zinc deposition takes place, while in the cathode range $(-0.1 \mathrm{~V}$ to $1.5 \mathrm{~V})$ the counter reaction takes 
place. Both voltammograms perfectly overlap the complete voltammogram (1.5 $\mathrm{V}$ to $1.5 \mathrm{~V}$ ), thus demonstrating that the behaviour of the electrolyte at the cathode does not influence its behaviour at the anode.

\subsubsection{INFLUENCE OF VARIOUS SUbSTRATES}

To study the influence of different graphite types on the deposition of zinc at the anode, four commercially available graphite types were tested, in addition to the standard graphite described in Section 6.2. These types are:

1. Sigraflex, a flexible graphite type with an Iron core $^{2}$;

2. SGL Bipolar, a smooth inflexible graphite sheet;

3. SGL felt gray, a porous graphite sheet;

4. SGL felt black, a porous graphite sheet.

In Figure 6.3 the electrochemical behaviour of the graphite types is shown. It can be seen that the over-all behaviour of all graphite types is similar. Between -1.5 $\mathrm{V}$ and $-0.5 \mathrm{~V}$, (the anode side), the voltammograms for all substrates are almost identical. The largest differences in this range are in the height of the peak at $-0.6 \mathrm{~V}$. In the range between $-1.5 \mathrm{~V}$ and $0.5 \mathrm{~V}$ larger differences are visible.

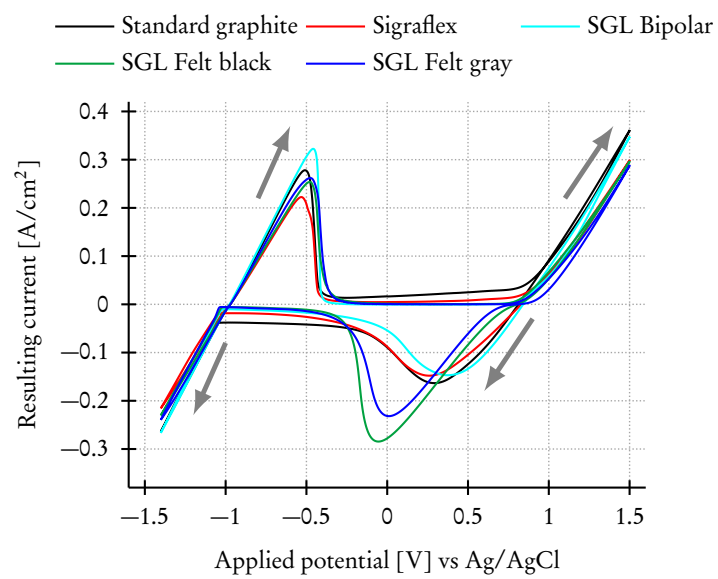

Figure 6.3: Cyclic voltammogram of standard electrolyte for various substrates.

The Sigraflex and SGL Bipolar substrates show very similar behaviour to the standard graphite. However, the SGL felt gray and SGL felt black substrates do show differences. Here, the lower peak is located around -0.1 V while the other substrates show this peak at around $0.3 \mathrm{~V}$. The peak is also significantly higher

\footnotetext{
${ }^{2}$ Note that the iron core is completely encased in the graphite compound, and thus is never exposed to the electrolyte
} 
for SGL felt black and SGL felt gray substrates than for the standard graphite. These differences are most likely attributed to the physical properties of the substrate. Where the standard graphite, Sigraflex and SGL Bipolar substrates have smooth like surfaces, the SGL felt black and SGL felt gray substrates have porous surfaces. However, in the potential range where zinc deposition at the anode occurs, between $-1.5 \mathrm{~V}$ and $0.5 \mathrm{~V}$ the behaviour of all tested substrates is similar to the standard graphite, showing that all four graphite types are potentially usable in the zinc-based battery as a replacement of the standard graphite.

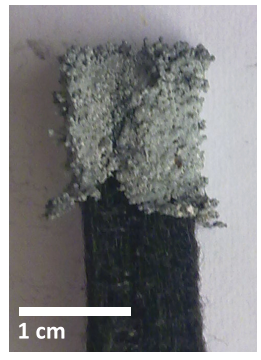

(a) SGL felt black

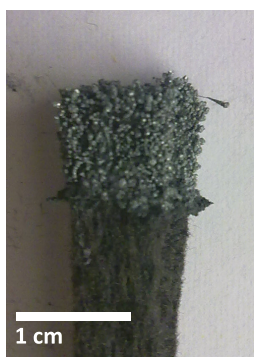

(b) SGL felt gray

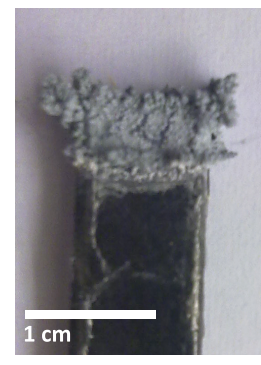

(c) Sigraflex

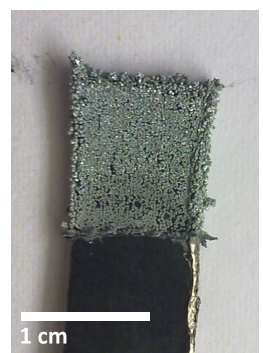

(d) SGL Bipolar

Figure 6.4: Morphology of zinc deposited at $-1.3 \mathrm{~V}$ for 1 hour on varied substrates from standard electrolyte.

In Figure 6.4, the morphology of the zinc deposited at the anode surface, on four different substrates is shown. In all four cases, the zinc layer is deposited from standard electrolyte by applying a potential of $-1.3 \mathrm{~V}(\mathrm{vs} \mathrm{Ag} / \mathrm{AgCl}$ ) for one hour. From visual inspection it is immediately clear that the morphology of the deposited zinc differs significantly for the various substrates. Both the SGL felt black and the SGL felt gray electrodes (Figures 6.4a,and 6.4b) are mostly smooth. The irregularities in the zinc layer may be attributed to the porosity of the substrate material. There are also some dendrites which are mostly needleshaped. The Sigraflex electrode (Figure 6.4c) shows broad dendrites, similar to the dendrites on the standard graphite. Furthermore the surface of the deposited zinc layer seems rough and cracked. The SGL bipolar electrode (Figure 6.4d) shows no dendrites, meaning that the zinc is deposited as one smooth layer. However, there are some irregularities towards the interface between the area where zinc was deposited and where no zinc was deposited. The absence of dendrites is in sharp contrast with a zinc layer deposited on standard graphite (Figure 6.2a) where dendrites are abundant.

From the cyclic voltammetry experiments and visual inspection of the electrodes, it can be concluded that:

- The electrochemical behaviour of the electrolyte at the anode is nearly identical for all four tested substrates. 
- The results of the CV experiments show that all four tested substrates are a suitable replacement for the standard graphite electrode in a zinc-based secondary battery.

- The SGL bipolar electrode (Figure 6.4d) shows the least dendrite formation, out of all tested substrates.

- The Sigraflex substrate (Figure 6.4c) is both in its electrochemical behaviour and in the dendrite formation most similar to the standard electrode.

\subsubsection{INFLUENCE OF VARIOUS ADDITIVES}

Preliminary research on this subject indicated that compounds containing Magnesium or Manganese may have the potential to reduce dendrite formation. Therefore the influence of magnesium bromide $\left(\mathrm{MgBr}_{2}\right)$ and manganese sulphate $\left(\mathrm{MnSO}_{4}\right)$ on the deposition behaviour of zinc was studied. The zinc layers were deposited on a standard graphite electrode from $1 \mathrm{M} \mathrm{ZnBr}_{2}$ (standard electrolyte) plus $0.1 \mathrm{M}$ of the co-depositor material. Firstly the influence of the co-depositor on the electrochemical behaviour was studied.

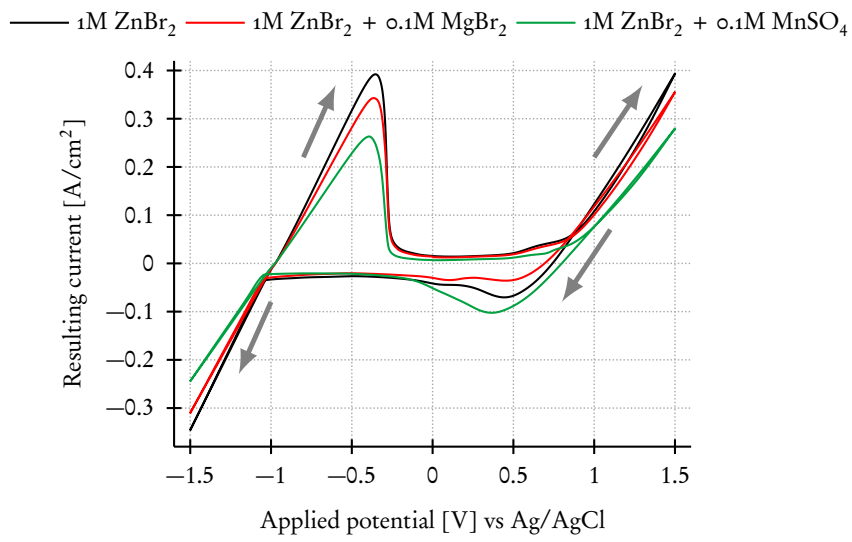

Figure 6.5: Cyclic voltammogram for various electrolytes on standard graphite.

In Figure 6.5, the voltammograms of the zinc depositions on standard graphite from $1 \mathrm{M} \mathrm{ZnBr}_{2}+0.1 \mathrm{M}$ of the selected co-depositors are shown in comparison to a voltammogram of zinc deposited under reference conditions. The voltammograms of $1 \mathrm{M} \mathrm{ZnBr}_{2}+0.1 \mathrm{M} \mathrm{MgBr}_{2}$ and $1 \mathrm{M} \mathrm{ZnBr}_{2}+0.1 \mathrm{M} \mathrm{MnSO}_{4}$ show only slight differences to the voltammogram of the reference condition. The main difference in the potential range where zinc deposition occurs $(-1.5 \mathrm{~V}$ to $-0.1 \mathrm{~V})$ is in the height of the peak around $-0.4 \mathrm{~V}$. This peak in the voltammogram of 1 $\mathrm{M} \mathrm{ZnBr}_{2}+0.1 \mathrm{M} \mathrm{MnSO}_{4}$ is significantly lower than the peaks in the voltammograms of $\mathrm{MgBr}_{2}$ and $1 \mathrm{M} \mathrm{ZnBr}_{2}$ and of the standard electrolyte, so a lower current 
results from the same potential. This difference in electrochemical behaviour is likely to have a negative influence on the battery performance, as a lower resulting current at the anode is likely to result in a lower over-all battery current, compared to the reference conditions.

To determine the influence of both of the co-depositors on the deposition behaviour, a deposition test (using chrono-amperometry) was performed on a standard graphite anode and electrolytes containing the two suggested co-depositors. The zinc-layers, deposited for 1 hour at $-1.3 \mathrm{~V}$ (vs Ag/AgCl), are shown in Figure 6.6. Both co-depositors are observed to have a significant influence on the behaviour of the deposition of the zinc-layer. From visual inspection it is immediately clear that neither the zinc layer deposited from $1 \mathrm{M} \mathrm{ZnBr}_{2}+0.1 \mathrm{M} \mathrm{MgBr}_{2}$ (Figure 6.6a) nor the zinc layer deposited from $1 \mathrm{M} \mathrm{ZnBr}_{2}+0.1 \mathrm{M} \mathrm{MnSO}_{4}$ (Figure 6.6c) shows significant dendrite formation. This is in sharp contrast with the dendrites formed for a deposition with $1 \mathrm{M} \mathrm{ZnBr}_{2}$ without co-depositors (see Figure 6.2a). Since the differences in the deposited zinc layers between the two electrolytes are so small, the anodes were also inspected with an optical microscope ( see Figures 6.6b and 6.6d). It is observed that the morphology of the zinc layers, deposited with both co-depositors, is very smooth. In particular, the zinc layer deposited from $1 \mathrm{M} \mathrm{ZnBr}_{2}+0.1 \mathrm{M} \mathrm{MgBr}_{2}$ (Figures 6.6a, 6.6b) seems evenly distributed over the anode surface and therefore is especially useful in zinc-based batteries.

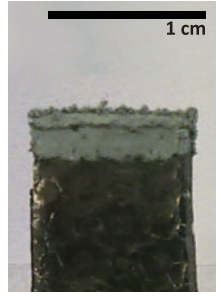

(a) $\mathrm{MgBr}_{2}$

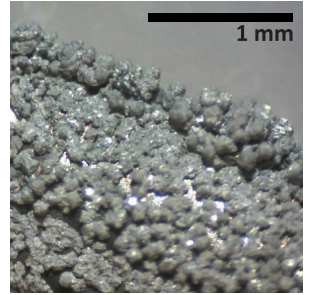

(b) $\mathrm{MgBr}_{2}(6 \circ x)$

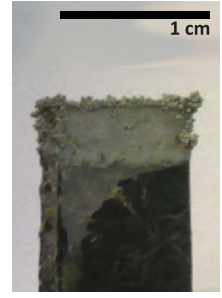

(c) $\mathrm{MnSO}_{4}$

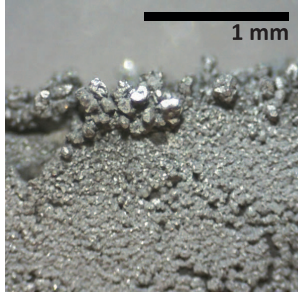

(d) $\mathrm{MnSO}_{4}(6 \circ \mathrm{x})$

Figure 6.6: Morphology of zinc deposited at $-1.3 \mathrm{~V}$ for 1 hour on standard graphite from $1 \mathrm{M} \mathrm{ZnBr}_{2}+0.1 \mathrm{M}$ co-depositor. Pictures (b) and (d) were obtained using a standard optical microscope.

In the previous experiments, a ratio of 10:1 between the depositor and the codepositor was used. As this ratio was chosen for convenience, still it needs to be established what the optimal ratio is; i.e. where the surface of the deposited zinc layer is as smooth as possible, and where the influence of the co-depositor on the behaviour of the battery remains minimal. There should be an optimal ratio, because if the concentration of co-depositor is very low compared to the concentration of depositor, the deposition will be dominated by the depositor, and the morphology of the deposited layer will be as if there were no co-depositor present. On the other hand, if there is a high concentration of co-depositor, the 
morphology of the deposited layer will be similar to the characteristics of the co-depositor.

To get some insight in the optimal ratio, deposition tests were performed with electrolytes using other depositor / co-depositor ratios. In Figure 6.7, the morphology of zinc layers deposited at $1.3 \mathrm{~V}$ for $1 \mathrm{~h}$ on graphite from $1 \mathrm{M} \mathrm{ZnBr}_{2}$ and various concentrations of co-depositor is shown. From visual inspection of the zinc layers deposited from $\mathrm{ZnBr}_{2}$ and $\mathrm{MgBr}_{2}$, (see Figure 6.7a) it is immediately clear that for co-depositor concentrations that are significantly higher and lower than $0.1 \mathrm{M}$ there are significantly more dendrites formed than with a codepositor concentration of $1 \mathrm{M}$. Therefore, as hypothesized, there seems to be an optimum concentration of co-depositor for $\mathrm{MgBr}_{2}$ where the least dendrites are formed and in this case this seems to be around $0.1 \mathrm{M} \mathrm{MgBr}_{2}$. Visual inspection of zinc layers deposited from $\mathrm{ZnBr}_{2}$ and $\mathrm{MnSO}_{4}$ shows similar behaviour and the optimal co-depositor concentration of $\mathrm{MnSO}_{4}$ also seems to be $0.1 \mathrm{M}$.

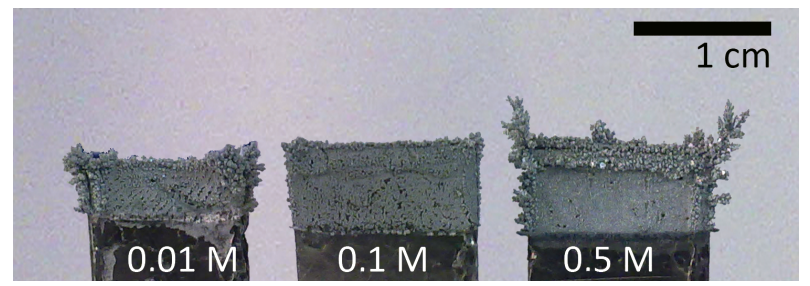

(a) $\mathrm{MgBr}_{2}$

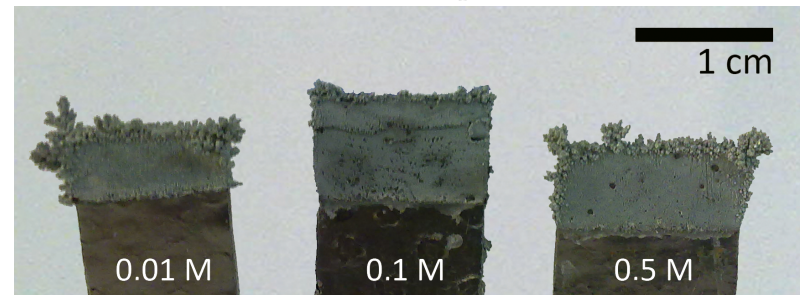

(b) $\mathrm{MnSO}_{4}$

Figure 6.7: Morphology of zinc deposited at $-1.3 \mathrm{~V}$ for 1 hour on standard graphite from $1 \mathrm{M} \mathrm{ZnBr}_{2}$, with different concentrations of co-depositor.

From the cyclic voltammetry experiments and visual inspection of the electrodes, it can be concluded that:

- Out of the two tested co-depositors, an electrolyte with $0.1 \mathrm{M} \mathrm{MgBr}_{2}$ as co-depositor behaves most like the standard electrolyte.

- From an electrochemical point of view both tested co-depositors are a suitable addition to the standard electrolyte in a zinc-based secondary battery. 
- For both co-depositors, zinc layers deposited from an electrolyte with codepositor concentrations significantly higher or lower than $0.1 \mathrm{M}$ resulted in zinc layers with significantly more dendrites than there are on zinc layers deposited from an electrolyte containing $0.1 \mathrm{M}$ co-depositor.

\subsubsection{COMBined IMPRovements}

In the previous sections the influence of four different substrates and two different co-depositors on the deposition of zinc from a $1 \mathrm{M} \mathrm{ZnBr}_{2}$ solution is discussed. In Table 6.1 a summary of the changes in dendrite formation is presented. Thereby the changes in dendrite formation are classified as $(=)$ no change in dendrite formation; $(>)$ increased dendrite formation; $(<)$ decreased dendrite formation. The largest decrease in dendrite formation was observed if (1) the substrate was replaced by a SGL Bipolar substrate, or (2) if $0.1 \mathrm{M}$ of $\mathrm{MgBr}_{2}$ was added to the electrolyte. In both cases no significant change to the electrochemical behaviour in CV was observed. Both replacing the substrate with SGL bipolar graphite and adding $0.1 \mathrm{M}$ of $\mathrm{MgBr}_{2}$ to the electrolyte cause reductions in the dendrite formation. It remains to investigate what the effect will be when both changes are made together; i.e., what the effect will be of depositing a zinc layer from 1 $\mathrm{M} \mathrm{ZnBr}_{2}+0.1 \mathrm{M} \mathrm{MgBr}_{2}$ on a SGL bipolar substrate.

Table 6.1: All electrode / electrolyte combinations tested for this research. $(=)$ No change in dendrite formation; $(<)$ Decreased dendrite formation; $(>)$ Increased dendrite formation.

\begin{tabular}{|c|c|c|c|}
\hline Substrate & Electrolyte & Additive & $\begin{array}{l}\text { Dendrite } \\
\text { formation }\end{array}$ \\
\hline \multicolumn{4}{|c|}{ Reference conditions: } \\
\hline Standard Graphite & ${ }_{1} \mathrm{M} \mathrm{ZnBr}_{2}$ & none & \\
\hline \multicolumn{4}{|l|}{ Varied Substrates } \\
\hline Sigraflex & ${ }_{1} \mathrm{M} \mathrm{ZnBr}_{2}$ & none & $<$ \\
\hline SGL felt black & ${ }_{1} \mathrm{M} \mathrm{ZnBr}_{2}$ & none & $=$ \\
\hline SGL felt gray & ${ }_{1} \mathrm{M} \mathrm{ZnBr}_{2}$ & none & $=$ \\
\hline SGL Bipolar & ${ }_{1} \mathrm{M} \mathrm{ZnBr} 2$ & none & $<<$ \\
\hline \multicolumn{4}{|l|}{ Varied Additives } \\
\hline Standard Graphite & $1 \mathrm{M} \mathrm{ZnBr}_{2}$ & $0.01 \mathrm{M} \mathrm{MgBr}_{2}$ & $=$ \\
\hline Standard Graphite & ${ }_{1} \mathrm{M} \mathrm{ZnBr}_{2}$ & $0.1 \mathrm{M} \mathrm{MgBr}_{2}$ & $<<$ \\
\hline Standard Graphite & $1 \mathrm{M} \mathrm{ZnBr}{ }_{2}$ & $0.5 \mathrm{M} \mathrm{MgBr}_{2}$ & $>$ \\
\hline Standard Graphite & ${ }_{1} \mathrm{M} \mathrm{ZnBr}_{2}$ & $0.01 \mathrm{M} \mathrm{MnSO}_{4}$ & $=$ \\
\hline Standard Graphite & ${ }_{1} \mathrm{M} \mathrm{ZnBr} 2$ & $0.1 \mathrm{M} \mathrm{MnSO}_{4}$ & $<$ \\
\hline Standard Graphite & ${ }_{1} \mathrm{M} \mathrm{ZnBr}_{2}$ & $0.5 \mathrm{M} \mathrm{MnSO}_{4}$ & $>$ \\
\hline
\end{tabular}

In Figure 6.8 the morphology of a zinc layer deposited from $1 \mathrm{M} \mathrm{ZnBr}_{2}+0.1$ $\mathrm{M} \mathrm{MgBr}_{2}$ on a SGL bipolar substrate, and the electrochemical behaviour during this deposition are shown. The voltammogram (Figure 6.8b) shows that the electrochemical behaviour of $1 \mathrm{M} \mathrm{ZnBr}_{2}+0.1 \mathrm{M} \mathrm{MgBr}_{2}$ on a SGL bipolar substrate 
closely resembles the behaviour of the reference conditions. In the potential range where zinc deposition occurs, between $-0.1 \mathrm{~V}$ and $-1.5 \mathrm{~V}$, both voltammograms are nearly identical, the largest difference is in the steepness of the peak at $-0.3 \mathrm{~V}$. On the other side of the voltammogram, between $-0.1 \mathrm{~V}$ and $1.5 \mathrm{~V}$ the differences are a bit larger. Both the positive current peak (at $1.5 \mathrm{~V}$ ) and negative current peak (at $0.3 \mathrm{~V}$ ) are lower for a deposition form $1 \mathrm{M} \mathrm{ZnBr}_{2}+0.1 \mathrm{M} \mathrm{MgBr}_{2}$ on a SGL bipolar substrate, than for a deposition from standard electrolyte on a standard electrode. However, as established in Section 6.3 the behaviour of the electrolyte at the cathode does not significantly influence the behaviour of the electrolyte at the anode. From visual inspection of the electrode (Figure 6.8a) it is immediately clear that there are significantly less dendrites than was the case in the reference conditions. The deposited zinc layer looks to be even smoother than layers deposited from $1 \mathrm{M} \mathrm{ZnBr}_{2}$ on SGL bipolar graphite substrate or from $1 \mathrm{M} \mathrm{ZnBr}_{2}+0.1 \mathrm{M} \mathrm{MgBr}_{2}$ on standard graphite substrate. This combination of the two changes ( $1 \mathrm{M} \mathrm{ZnBr}_{2}+0.1 \mathrm{M} \mathrm{MgBr}_{2}$ on a SGL bipolar substrate) is referred to as improved conditions in the remainder of this chapter.

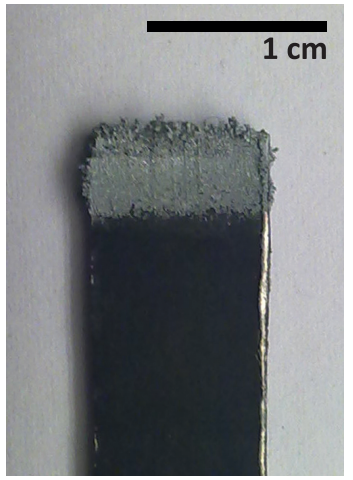

(a) Morphology

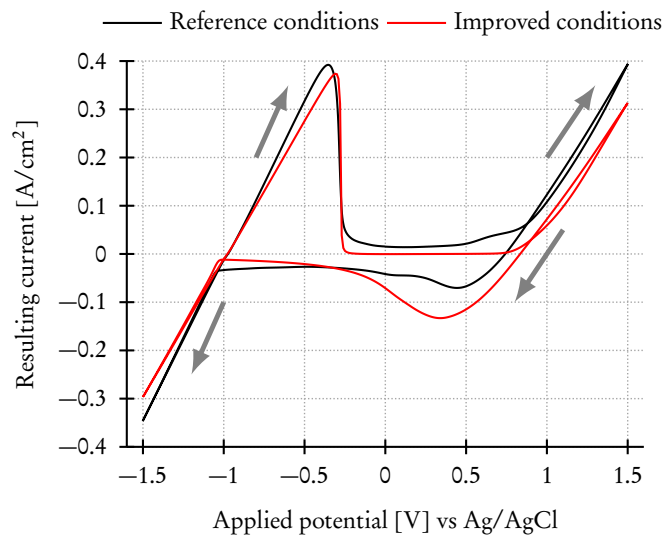

(b) Electrochemical behaviour

Figure 6.8: The morphology of zinc deposited at $-1.3 \mathrm{~V}$ for 1 hour on SGL bipolar graphite from $1 \mathrm{M} \mathrm{ZnBr}_{2}+0.1 \mathrm{M} \mathrm{MgBr}_{2}$ and the corresponding voltammograms showing the electrochemical behaviour of this deposition, compared to a deposition under reference conditions.

\section{Scanning Electron Microscopy analysis}

The morphology of the deposited zinc layer is further analysed using Scanning Electron Microscopy (SEM). The SEM analysis was only applied to the improvements that showed the most promising results. This implies that only one substrate is considered: SGL bipolar graphite, in combination with both co-depositors, in addition to the standard graphite and standard electrolyte. 
Firstly the zinc layer deposited from standard electrolyte on both substrates is analysed. In both cases zinc was deposited for 1 hour at -1.3 V. For both resulting images an area on the side of the electrode was selected where it was immediately clear that zinc had been deposited, but where no dendrite was visible. The image in Figure 6.9a shows a zinc layer deposited on a standard graphite electrode. In this case, clearly the zinc layer is very terraced, meaning that the thickness of the layer is uneven and in between the portions of different layer thickness there are steep edges. In addition to the variations in layer thickness the distribution over the surface is also uneven, as evidenced by the gaps (black spots) visible in the layer. In Figure 6.9b a zinc layer deposited on a SGL bipolar electrode is shown. In this case the deposited zinc layer is not terraced. While the thickness of the zinc layer still varies, the transition between areas of different thickness is smooth. There are still some gaps present in the deposited layer, but definitely less than shown in Figure 6.9a.

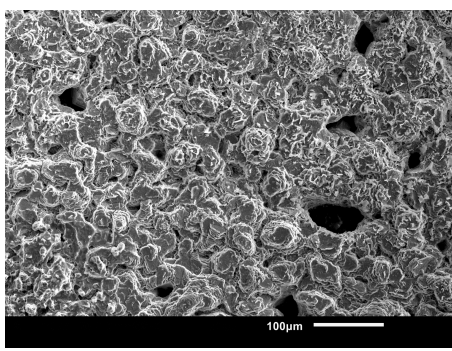

(a) Electrode: Standard graphite, Electrolyte: $1 \mathrm{M} \mathrm{ZnBr}_{2}$

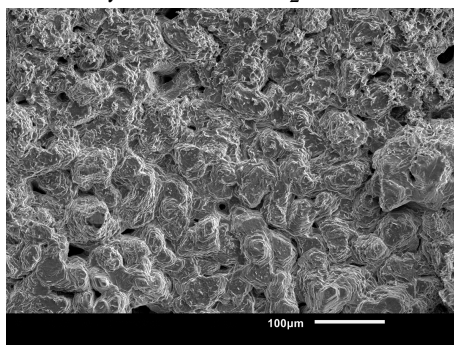

(c) Electrode: Standard graphite, Electrolyte: $1 \mathrm{M} \mathrm{ZnBr}_{2}+0.1 \mathrm{M}$ $\mathrm{MgBr}_{2}$

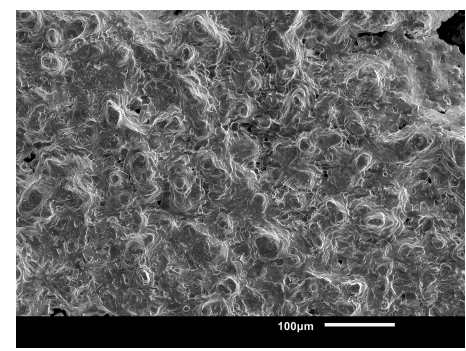

(b) Electrode: SGL Bipolar, Electrolyte: $1 \mathrm{M} \mathrm{ZnBr} 2$

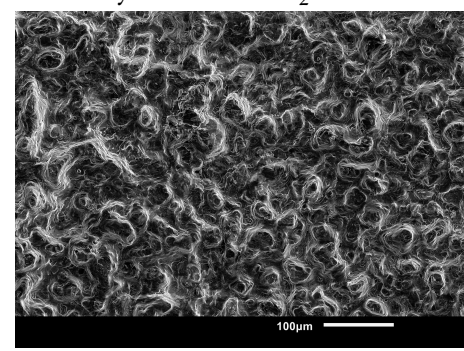

(d) Electrode: SGL Bipolar, Electrolyte: $1 \mathrm{M} \mathrm{ZnBr}_{2}+0.1 \mathrm{M}$ $\mathrm{MgBr}_{2}$

Figure 6.9: Scanning Electron Microscope pictures of the various zinc layers, recorded with a $200 x$ magnification.

Secondly, in Figure 6.9c, the zinc layer deposited from $1 \mathrm{M} \mathrm{ZnBr}_{2}+0.1 \mathrm{M}$ $\mathrm{MgBr}_{2}$ on a standard graphite electrode is given. As in the previous cases zinc was deposited for 1 hour at $-1.3 \mathrm{~V}$, and an area on the side of the electrode was selected where it was immediately clear that zinc had been deposited, but where 
no dendrite was visible. This zinc layer is also somewhat terraced, but clearly less than for the reference conditions, indicating that there is less variation in the thickness of the zinc layer than under the reference conditions (Figure 6.9a). There are again only a few gaps in the layer, indicating that the layer is evenly distributed along the substrate surface.

Lastly the zinc layer deposited under reference conditions (Figure 6.9a) is compared to the zinc layer deposited under improved conditions (Figure 6.9d). The zinc layer deposited under improved conditions shows very little terracing indicating that there are little hight differences in the zinc layer. Moreover the terracing that does occur is broad, indicating that the hight differences occur gradually. There are very little gaps in the zinc layer, indicating the layer is evenly distributed over the substrate surface.

In conclusion, the zinc layers deposited with one of the two changes (Figures $6.9 \mathrm{~b}$ and 6.9c), are smoother and less dendritic than a zinc layer deposited under standard conditions (Figure 6.9a). A zinc layer with both changes, i.e. under improved conditions (Figure 6.9d), is again smoother than a zinc layer deposited with only one of the changes applied.

\section{Electrochemical Impedance Spectroscopy analysis}

Considering the voltammetry of zinc deposition using the reference conditions and the improved conditions given in Figure 6.8b, there is a limited yet clear difference in the voltammetry between a deposition performed using the reference conditions and improved conditions. To make sure that this difference in the voltammetry causes no large differences in the behaviour of the battery, a better understanding of the processes occurring at the anode during deposition is needed. In order to gain more insight into the mechanism and kinetics of zinc deposition under the reference conditions and improved conditions an Electrochemical Impedance Spectroscopy (EIS) analysis [149] was performed. Figure 6.10 shows the impedance spectra of a deposition under the reference conditions (1 $\mathrm{M} \mathrm{ZnBr}_{2}$ on a graphite electrode) and the improved conditions (1 $\mathrm{M} \mathrm{ZnBr}_{2}$ + $0.1 \mathrm{M} \mathrm{MgBr}_{2}$ on a bipolar graphite electrode). The EIS measurements were performed during zinc deposition at a potential of $-1.3 \mathrm{~V}$ (vs $\mathrm{Ag} / \mathrm{AgCl}$ ), the deposition was started one hour before the EIS measurements were taken to make sure that the system had reached a steady state before the start of the measurements.

Figure 6.10a displays the impedance spectrum of the EIS measurements on the zinc deposition under standard conditions. The offset of the spectrum on the $\mathrm{x}$-axis at approximately $1.1 \Omega$ is associated with the resistance of the electrolyte; the higher the offset of the spectrum, the higher the internal resistance of the electrolyte. The width of the spectrum, in this case approximately $2.5 \Omega$, is associated with the charge transfer resistance. The relatively large charge transfer resistance is attributed to the crystallization processes and the relatively large over potential $(-1.3 \mathrm{~V})$ applied to drive the deposition. The impedance spectrum 


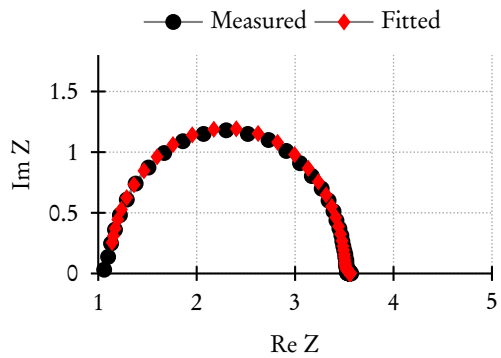

(a) Nyquist plot: Reference conditions

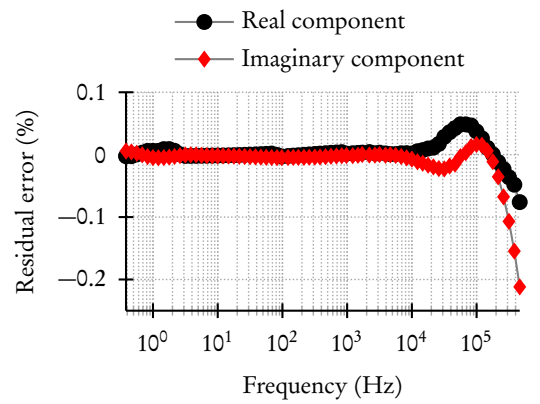

(c) Frequency error: Reference conditions

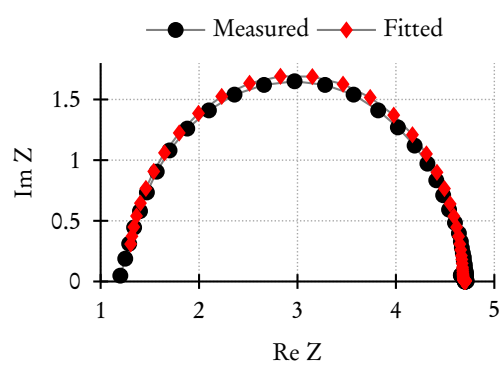

(b) Nyquist plot: Improved conditions

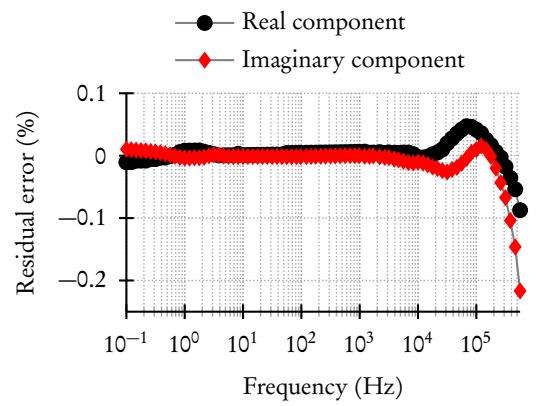

(d) Frequency error: Improved conditions

Figure 6.10: Impedance spectra and residual error plots for EIS measurements of zinc depositions under reference conditions and improved conditions and fitted using the EQUIVCRT software and circuit in Figure 6.11.

of the deposition under improved conditions is displayed in Figure 6.10b. In this case the offset of the graph is approximately $1.2 \Omega$, which is slightly larger than that of the standard conditions. The slightly higher electrolyte resistance may be related to the presence of magnesium ions in the electrolyte of the improved condition.

In order to understand the impedance spectra on a more detailed level the data was fitted using the equivalent circuit processing software (EQUIVCRT) and the method developed by Boukamp $[147,148]$. The fitted impedance spectra are also displayed in Figures 6.10a and 6.10b. The fitted spectra are nearly identical to the measured spectra. The residual error between the fitted data and the measured data is displayed in Figures 6.10c and 6.10d. It stayed within $0.1 \%$ over a wide range of frequencies, however larger errors were encountered at very high frequencies ${ }^{3}$. The equivalent circuit fitted using the EQUIVCRT software is displayed in Figure 6.11.

\footnotetext{
${ }^{3}$ Note that small numbers in the impedance spectra correspond to large frequencies in the residual error plots.
} 
The best fitted equivalent circuit (see Figure 6.11a) is relatively simple, consisting of three resistors $\left(R, R_{1}\right.$, and $\left.R_{2}\right)$, a capacitor $(C)$ and a constant phase element (Q). Resistor $\mathrm{R}$ corresponds to the electrolyte resistance, and resistor $\mathrm{R}_{1}$ corresponds to the charge transfer resistance. The values fitted for $R$ and $R_{1}$ (see Figure 6.11b) are nearly identical to the values obtained for both cases from the impedance spectra. The parallel setting of resistance $\mathrm{R}_{2}$ and constant phase element $Q$ may be associated with diffusion. The values for $R_{2}$ and $Q$ are very small for both the reference conditions and improved conditions, indicating that the zinc deposition is controlled by diffusion of ions towards the substrate surface and by adsorption at the substrate surface via a weak Van der Waals bond [150]. The small value for $\mathrm{C}$, present in both the reference condition and the improved condition, indicates that during the deposition process electrolyte is likely enclosed in the pores of the substrate surface.

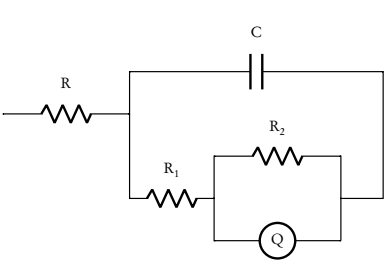

(a)

\begin{tabular}{l|ll}
\hline & Reference condition & Improved condition \\
\hline $\begin{array}{l}\text { Substrate } \\
\text { Electrolyte }\end{array}$ & $\begin{array}{l}\text { Standard graphite } \\
1 \mathrm{M} \mathrm{ZnBr}_{2}\end{array}$ & $\begin{array}{l}\text { SGL Bipolar } \\
1 \mathrm{M} \mathrm{ZnBr}_{2} \\
+0.1 \mathrm{M} \mathrm{MgBr}_{2}\end{array}$ \\
\hline $\mathrm{U}_{\text {applied }}(\mathrm{V})$ & -1.3 & -1.3 \\
$\mathrm{R}(\Omega)$ & 1.11 & 1.28 \\
$\mathrm{C}(\mathrm{F})$ & $1.33 \cdot 10^{-6}$ & $9.09 \cdot 10^{-7}$ \\
$\mathrm{R}_{1}(\Omega)$ & 2.39 & 2.44 \\
$\mathrm{R}_{2}(\Omega)$ & $5 \cdot 46 \cdot 10^{-2}$ & $7.50 \cdot 10^{-1}$ \\
$\mathrm{Q}(\mathrm{F})$ & $1.49 \cdot 10^{-1}$ & $3.22 \cdot 10^{-1}$ \\
$\mathrm{n}(-)$ & $6.75 \cdot 10^{-1}$ & $9 \cdot 99 \cdot 10^{-3}$ \\
\hline
\end{tabular}

(b)

Figure 6.11: (a) Circuit representing the processes likely to occur during zinc deposition and (b) values of the elements in the circuit for both the reference and improved conditions.

In conclusion, the impedance spectra for the reference conditions and improved conditions are very similar, the differences in the offset and width of the curve are attributed to the differences in the electrolyte. Both spectra can be fitted to the same equivalent circuit (Figure 6.11), with slightly different values for all components. The presence of the elements and the corresponding values for both the reference conditions and improved conditions, suggest a deposition process dominated by diffusion towards the surface of the carbon electrode and by heterogeneous nucleation.

\subsection{Conclusion}

Dendrite formation during the electrochemical deposition of zinc can cause problems in the operation of the Seasalt battery. Any practical solution to this problem should have no (negative) influence on the operation of the zinc-based secondary battery as a whole, meaning that the electrochemical behaviour of the electrolyte at the anode should be the same in all cases whether the practical solution is applied or not. To get some more insight, the deposited zinc layers were analysed using optical microscopy as well as scanning electron microscopy, the behaviour of the electrolyte at the anode was analysed using cyclic voltammetry. 
Firstly various substrates, which are possible replacements for the substrate used in the standard conditions were researched. The used electrode materials all have little influence on the behaviour of the electrolyte at the anode. The SGL bipolar graphite shows the least dendrite formation of all tested substrates.

Secondly, the addition of several co-depositor materials to the electrolyse has been researched. As with the substrate, for a practical solution, the co-depositor should have as little influence as possible on the behaviour of the electrolyte at the anode. It is demonstrated that the addition of $0.1 \mathrm{M} \mathrm{MgBr}_{2}$ to the electrolyte causes a significant reduction of the formation of dendrites, while the behaviour of the electrolyte at the anode is influenced very little. Furthermore, it is demonstrated experimentally that both solutions combined (improved conditions), result in a further reduction of dendrite formation.

Additionally, an electrochemical impedance spectroscopy study was conducted on the deposition using both the reference conditions and improved conditions. It is shown that the deposition under both sets of conditions is a process dominated by heterogeneous nucleation. The processes are slightly different, yet sufficiently similar to ensure that the deposition under the improved conditions does not (negatively) influence the overall working of the zinc-based secondary battery as a whole.

In summary, the best results (i.e. the biggest reduction in dendrite formation) are achieved when both the SGL bipolar graphite is used and $0.1 \mathrm{M} \mathrm{MgBr}_{2}$ is added to the electrolyte. This solution has been successfully applied in the design and optimization of the Seasalt battery as presented in Chapter 5 . 


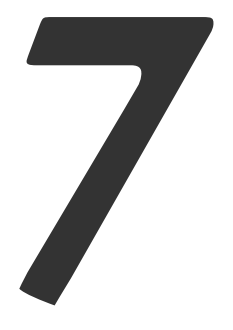

\section{Conclusion}

In this thesis three different subjects are discussed. Although seemingly very different, the three subjects all cover different aspects of the central question introduced in Chapter 1:

How can electricity storage, in the form of batteries, contribute to the electrical self-sufficiency of neighbourhoods, and increase the usage of locally produced electricity from renewable sources.

It is not the intention to give one comprehensive answer to this question in this thesis, as the central question is very broad and could be considered a field of research in itself. The goal is rather to shed some light on different aspects of this question, in order to contribute to the whole chain of battery development. Or in other words, to get a more practical grip on what is needed for houses and neighbourhoods to become more electrically self-sufficient, while using sustainable, environmentally friendly energy sources. In the following sections, the research and contributions following the three sub-questions formulated in Chapter 1 are discussed.

\subsection{The DiBu-Model}

The research presented in Chapters 2 and 3 is focussed on answering the first sub-question:

Is it possible to develop a model for the prediction of the SoC of a battery, suitable for various battery types, which is both simple and accurate enough to be used in simulation tools and HEMS's?

To answer this question, a simple yet accurate model for the prediction of the battery state of charge has been developed specifically for usage in simulation tools and for prediction and model predictive control within smart grid applications, 
namely the Diffusion Buffer model (DiBu-model). The DiBu-model yields accurate predictions of the state of charge, while being simple enough to be applied in the mentioned tools and applications. The model predicts the battery voltage during charging, discharging and idle periods, and based on these voltages the state of charge is predicted. To apply the model, first four parameters of the model have to be determined from measurements on the battery in question.

As a means of verification, the $\mathrm{DiBu}$-model is applied to predict the state of charge of Pb-acid, Li-Poly and LiFePo batteries. For Pb-acid batteries, the difference between the state of charge predicted using the $\mathrm{DiBu}$-model $\left(\mathrm{SoC}^{\mathrm{DiBu}}\right)$, and the state of charge calculated from the measurements $\left(\mathrm{SoC}^{\text {meas }}\right)$ is shown to be less than $10 \%$ for a state of charge prediction over 3000 minutes ( $\sim 50$ hours) while frequent charge and discharge actions were applied. It is also shown that the accuracy of the state of charge predictions using the DiBu-model, is equal to, or in some cases better than the accuracy of state of charge predictions using the well established KiBaM model. However, as the KiBaM model is more complicated, and (micro)grid simulations require simple yet accurate models, the $\mathrm{KiBaM}$ model is less suitable for usage in tools for simulation, prediction and control of smart grids. In the case of the Li-Poly batteries the difference between $\mathrm{SoC}^{\mathrm{DiBu}}$ and $\mathrm{SoC}^{\text {meas }}$ is shown to be around $4 \%$ for a state of charge prediction over 600 minutes ( $\sim 10$ hours). In case of the LiFePo batteries the difference between $\mathrm{SoC}^{\mathrm{DiBu}}$ and $\mathrm{SoC}^{\text {meas }}$ is shown to be around $12 \%$ for a state of charge prediction over 1200 minutes ( 20 hours). It is also shown that the accuracy of the predictions can be improved by periodically updating the actual values for the battery voltage and state of charge.

However, for the Seasalt battery ${ }^{1}$ it was determined that the DiBu-model is not completely suitable for the prediction of the SoC during charging, as the behaviour of a Seasalt battery during charging is very different from that of other batteries (e.g. Pb-acid and Li-Poly). Therefore an extension to the DiBu-model has been developed (see Section 5.5), which is able to predict the SoC of Seasalt batteries. The extension for Seasalt batteries consists of a modified equation to calculate the voltage during the charge step, and requires the determination of one different parameter. It is demonstrated that using the $\mathrm{DiBu}$-model (with the modified charge step equation) the SoC can be predicted accurately over 1100 minutes ( $\sim 18$ hours), where the difference between SoC ${ }^{\mathrm{DiBu}}$ and SoC ${ }^{\text {meas }}$ is generally around $2 \%$.

Furthermore, the DiBu-model is integrated in DEMKit, a smart-grid simulation and optimization toolkit. It is shown that the DiBu-model is quite suitable for use within the DEMKit simulation software. It is also demonstrated that the power profiles realized with the DiBu-model match the planned power profiles quite closely (the difference is generally around $2 \%$ ), in some instances even more closely than the power profiles realized with an ideal battery model. Additionally,

\footnotetext{
${ }^{1}$ The Seasalt battery is a novel battery currently under development at Dr Ten B.V., see Chapter 5 and Section $7 \cdot 3$
} 
it is demonstrated that the power profiles realized with the DiBu-model match the real behaviour of the battery quite well. Comparisons between the predicted SoC and the SoC calculated from measurements show that the predictions made using the $\mathrm{DiBu}$ model match reality quite well. The difference between the $\mathrm{DiBu}-$ model prediction and the measured SoC is generally less than 1,5\%. Only in time intervals where the highest amount of power is demanded from the battery, the deviation between the predicted SoC and the measured SoC increases. Overall, the application of the DiBu-model results in an improved accuracy of the simulation results.

\subsection{THE 16 HOUSES CASE}

The research presented in Chapter 4 is focussing on answering the second subquestion:

How can the electrical self-sufficiency of neighbourhoods be improved, by making use of batteries and smart control, while the user comfort of the inhabitants is guaranteed?

To answer this question, an analysis of the integration of batteries in multi-energy smart-grids is made. For this analysis, the electricity and heating infrastructure of a 16 house neighbourhood was modelled in DEMKit. Firstly, the possibilities of operating an idealized neighbourhood in soft-islanded (almost disconnected from the national electricity grid) mode in the Netherlands are researched. Secondly, the possibilities of operating a real neighbourhood, located in Markluiden, the Netherlands, in that same way are investigated. To be able to make fair comparisons, a new metric, the Degree of Autarky is introduced as a measure of how far one can operate a neighbourhood as an islanded microgrid.

To help in the determination of the proper size (and configuration) of all equipment used in the neighbourhood, a method of simultaneous equipment sizing is proposed. First, three weeks with "worst case scenarios" for outside conditions were selected (e.g. a week with low electricity production from the PV-panels, and low heat requirements). The energy usage for the whole neighbourhood is then simulated for the selected weeks, for a given set of equipment sizes (e.g. battery capacity). The simulation of such three weeks with "worst case scenarios" replaces the need for whole year simulations and speeds up the equipment sizing process. From the simulation results a sensible choice for the equipment size is made. Using this base setting, a series of simulations is done, whereby always the size of one characteristic value is adapted (e.g. the total weekly grid power demand in $\mathrm{kWh}$ ), this results in a quick and comprehensive way to find the best size and configuration of the equipment in the neighbourhood. In this thesis, the focus is mainly on sizing the PV-panel area, the CHP heat to power ratio and the battery capacity. Based on the results it is concluded that this methodology is quite effective. However, for practical application conceivably more 
characteristics can be and have to be taken into account, e.g. the efficiency of the PV-panels or the size of the CHP buffer.

Based on the determined appropriate sizes of all relevant equipment, the energy usage for the neighbourhood is simulated for a full year. Hereby also possibilities of operating the neighbourhood in a soft-islanded mode are investigated for several scenarios:

- NB; The battery is not used, no smart control is applied.

- NC; The battery is used, no smart control is applied.

- PSE; The battery is used, smart control using profile steering is applied.

- PSA; The battery is used, smart control using double sided auction is applied.

- PSE- $B$; The battery is used, the battery is simulated using the DiBu-model, smart control using profile steering is applied.

Generally it is concluded that complete islanding of the neighbourhoods would be very costly. On the one hand, to reduce the electricity imports to zero an unrealistic amount of electrical energy storage has to be installed, most of which will only be used a few hours per year. On the other hand, to reduce the electricity exports, the CHP should produce no more electricity than strictly necessary. This would mean that the heat-demand would not be met at all times, which would cause a loss of comfort, which is not acceptable. Therefore, softislanding seems to be a better solution. Hereby an average daily import of 0.1 $\mathrm{kWh}$ per house can be considered a marginal load for the grid. Hence, it is concluded that Soft-islanded microgrids are able to fulfil their energy demand most of the time, from locally produced electricity, but still a connection to the main grid is needed for the moments when local generation is insufficient or too high. It is assumed that in soft-islanded operation, the level of comfort should be the same as for a normal neighbourhood, meaning that all heat and electricity demands are met at all times. One drawback in this setting is that the CHP produces electricity as a by-product when heat is generated, regardless of the electricity demand. Hence overproduction of electricity can occur, which can potentially cause stress in the main grid. This could be solved by taking into account a limit for the amount of electricity that can be delivered back to the grid when making the choice for the proper heat to electricity ratio of the CHP. Alternatively a combination of a CHP and heat pumps can be installed to reduce the export of electricity.

\subsubsection{The IDEAL NEIGHBOURHOOD}

The considered idealized neighbourhood is a futuristic "greenfield" neighbourhood which has quite specific features, like e.g. state of the art insulation. Furthermore, each house is equipped with several fixed load and flexible load appliances. Using the simultaneous sizing method it was determined that each 
house should also be equipped with $4 \mathrm{kWh}$ battery, $22.4 \mathrm{~m}^{2} \mathrm{PV}$-panels and the houses should share a $60 \mathrm{~kW}_{\mathrm{th}} / 30 \mathrm{~kW}_{\mathrm{el}} \mathrm{CHP}$ unit. The results of the sizing and simulations indicate that either substantial battery storage or overproduction from renewable sources is required to achieve a soft islanded microgrid.

The over-all best results are gained in the PSE scenario, with a DoA of over $99 \%$. In this scenario electricity imports from the grid are limited to only 37 $\mathrm{kWh}$ /year. However, $5 \mathrm{MWh}$ /year is still exported to the grid. The results of the simulations over a whole year indicate that in all cases the PV installations are "over-dimensioned" in the sense that less than half of all locally generated energy is consumed locally. Hereby, again the PSE case performs best at $44 \%$. Compared to the PSE scenario, the PSE-B results in a $2 \%$ lower self-consumption, $9 \%$ less electricity buffered, a $1 \%$ lower DoA and a $41 \%$ higher electricity import from the grid. But overall, the simulations show that profile steering in general does not result in high discharge peaks and high charge powers, such that the realistic battery can closely follow the original planning. Moreover, the PSE-B yields more realistic results and a more realistic prediction of the DoA that can be achieved for a given battery capacity.

\subsubsection{The ReAl neighbourhood in Markluiden}

For the model of the real neighbourhood in Markluiden, the same basic setup as for the ideal neighbourhood is used, however the location (and roof orientation), size and temperature demand (as a result of outdated thermal insulation) of each house is adapted to match its real counterpart. As could be expected, the determination of the appropriate equipment size yields different results than for the ideal neighbourhood. In the Markluiden neighbourhood, each house has to be equipped with a $6 \mathrm{kWh}$ battery, $16 \mathrm{~m}^{2} \mathrm{PV}$-panels and the houses share a 250 $\mathrm{kW}_{\mathrm{th}} / 111 \mathrm{~kW}_{\mathrm{el}} \mathrm{CHP}$ unit.

The best results are achieved in the PSA case, when storage and optimal control are used, yielding a DoA of $91 \%$. In this case, the electricity imported from the grid amounts to $402 \mathrm{kWh} /$ year. However, the amount of electricity exported to the grid is quite high, at $13 \mathrm{MWh}$ /year, meaning that the neighbourhood has quite a serious overproduction of energy, especially in winter. On the one hand, the neighbourhood performs much better in the PSA case when compared to the $N C$ case. Hence, more of the electricity generated by the PV-panels is used locally, and less electricity is imported from the grid. On the other hand, for both the NC and PSA case, the largest part of the consumed electricity is provided by the CHP unit. This is due to the high heat demand, which results in a CHP producing too much electricity while fulfilling the heat demand. This situation leads to a very different operation of the system compared to the present situation in Markluiden, where almost the entire electricity load is imported from the grid, with a resulting DoA of $3.7 \%$. 


\subsubsection{BOTH NEIGHBOURHOODS COMPARED}

While the battery capacity and PV-panel area are similar for both neighbourhoods, there is a large difference between the capacity of the heat storage devices $(250 \mathrm{kWh}$ and $5 \mathrm{MWh})$ and the power of the CHP $\left(60 \mathrm{~kW}_{\text {th }}\right.$ and $\left.250 \mathrm{~kW}_{\mathrm{th}}\right)$, i.e. the neighbourhood in Markluiden needs a CHP four times more powerful than the ideal neighbourhood, and 20 times more storage capacity. The difference between the neighbourhoods becomes even more clear if the weekly electricity production and demand over the whole year is analysed. The electricity produced by the PV-panels is roughly the same for both neighbourhoods, however, the share in the total electricity production is quite different. While the shares of electricity produced by the CHP and PV-panels are roughly equal and complementary for the ideal neighbourhood, the share of electricity produced by the PV-panels in Markluiden is only a small part. In the ideal neighbourhood as well as in Markluiden the electricity demand is met by electricity generated by the PV-panels for roughly 30 weeks in the year. During the other weeks the CHP produces enough electricity to meet the demand. In the ideal neighbourhood, the electricity production is dominated by the PV-panels for 28 weeks of the simulated year (weeks $14-42$ ) whereas this is only 16 weeks (week 20-36) for the neighbourhood in Markluiden.

The electricity production in the ideal neighbourhood is matched quite well to the demand, although there is some overproduction in the weeks where the CHP is very active. This overproduction is limited to $1.37 \mathrm{MWh} /$ week on average, with the highest overproduction (3.01 MWh/week) occurring in week 49. The maximum production is around 2.5 times as large as the demand at the time. In Markluiden, however, the match between demand and production is not that good, leading to an overproduction of $3.76 \mathrm{MWh} /$ week on average. The highest overproduction (9.13 MWh/week) occurs in week 4, which is around 7.5 times as large as the demand at the time. As the electricity production by the CHP is only a by-product of the heat generation, it is concluded that before a CHP, PVpanels, batteries, and smart control are used in the Markluiden neighbourhood, the thermal demand should be reduced, e.g. through better insulation of all houses.

\subsection{The Seasalt Battery}

The research presented in Chapters 5 and 6 is focussed on answering the third sub-question:

What are the characteristics, advantages and disadvantages of the Seasalt battery, and is the Seasalt battery suitable for electricity storage at the house or neighbourbood level, in the context of smart-grids?

To address this question, various aspects of the Seasalt battery are analysed, including electrochemical behaviour, charge / discharge characteristics and safety. 
Furthermore, several Seasalt batteries were integrated in a microgrid, to evaluate the performance in practical settings.

\subsubsection{Characteristics}

The Seasalt battery is an alternative battery for stationary applications. It is designed with three goals in mind, the Seasalt battery should be 1) Environmentally responsible, 2) Durable and 3) Affordable. To satisfy the goal of environmental responsibility, none of the components used in the electrolyte or the electrodes has a GHS hazard classification beyond beyond Warning, Corrosive or Danger to aquatic life. Although these signal words sound ominous, these classifications are also given to dishwasher soap, toilet cleaner and laundry detergent, all present in the average kitchen sink. The durability of a prototype Seasalt battery has been demonstrated by performing around 1400 consecutive charge / discharge cycles. Although clear signs of ageing and degradation are present after these 1400 cycles, the Seasalt battery still operates at an efficiency above $50 \%$ of the initial energy-efficiency, and above $75 \%$ of the initial current-efficiency.

The Seasalt battery behaves somewhat different compared to commonly used batteries (e.g. Pb-acid and Li-Poly batteries). The voltage of a Seasalt battery during charging remains constant (at $1.8 \mathrm{~V}$ per cell) whereas voltage of $\mathrm{Pb}$-acid and Li-Poly batteries gradually rises during charging. This is neither an advantage nor a disadvantage. However, there is an operational challenge, because in most batteries the gradual voltage rise is used by the charging equipment as a measure for when a battery is fully charged. This can not be done with a Seasalt battery, as the charging voltage is almost constant. During discharge the Seasalt battery behaves largely similar to e.g. Pb-acid and Li-Poly batteries. The voltage gradually declines until the battery is nearly discharged, then the voltage drops rapidly. The voltage of a Seasalt battery declines slower than comparable $\mathrm{Pb}$-acid and Li-Poly batteries, whereas the change to rapid decline is more sudden. This is an advantage as the battery delivers a more stable voltage until it is almost completely discharged.

Furthermore, the Seasalt battery is tested in a practical setting in the Veldegge neighbourhood, as part of the Gridflex project. In this project multiple 24 $\mathrm{V}$ versions of the Seasalt battery are deployed throughout the neighbourhood. Although, during installation several problems were encountered that make deployment of the Seasalt battery difficult (e.g due to problems with the used inverter and the battery management system), the deployed batteries perform largely as expected.

\subsubsection{DENDRITE FORMATION}

Dendrite formation during the electrochemical deposition of zinc can cause problems in the operation of the Seasalt battery. Any practical solution to this problem should have no (negative) influence on the operation of the zinc-based 
secondary battery as a whole, meaning that the electrochemical behaviour of the electrolyte at the anode should be the same in all cases whether the practical solution is applied or not. To get some more insight, the deposited zinc layers were analysed using optical microscopy as well as scanning electron microscopy, the behaviour of the electrolyte at the anode was analysed using cyclic voltammetry.

Firstly various substrates, which are possible replacements for the substrate used in the standard conditions were researched. The used electrode materials all have little influence on the behaviour of the electrolyte at the anode. The SGL bipolar graphite shows the least dendrite formation of all tested substrates. Secondly, the addition of several co-depositor materials to the electrolyse is researched. As with the substrate, for a practical solution, the co-depositor should have as little influence as possible on the behaviour of the electrolyte at the anode. It is demonstrated that the addition of $0.1 \mathrm{M} \mathrm{MgBr}_{2}$ to the electrolyte causes a significant reduction of the formation of dendrites, while the behaviour of the electrolyte at the anode is influenced very little. Furthermore, it is demonstrated experimentally that both solutions combined (improved conditions), result in a further reduction of dendrite formation. Additionally, an electrochemical impedance spectroscopy study was conducted on the deposition using both the reference conditions and improved conditions. It is shown that the deposition under both conditions is a process dominated by heterogeneous nucleation. The processes are slightly different, yet sufficiently similar to ensure that the deposition under the improved conditions does not (negatively) influence the overall working of the zinc-based secondary battery as a whole. The best results (i.e. the biggest reduction in dendrite formation) are achieved when both the SGL bipolar graphite electrode is used and $0.1 \mathrm{M} \mathrm{MgBr}_{2}$ is added to the electrolyte.

\subsection{RECOMMENDATIONS FOR FUTURE WORK}

The research presented in this thesis has sparked various questions and ideas for new research. Additionally, some existing questions have been left unanswered and some research has been left unfinished. Therefore there are various topics for future work relating to all three subjects discussed in this thesis:

\section{The DiBu-model}

- One of the advantages of the DiBu-model is its compatibility with different battery types (Pb-acid, Li-Poly and LiFePo batteries). This makes the model useful in various situations. The usefulness of the model could be expanded if the compatibility with additional battery types, such as e.g. Nickel-Cadmium and Nickel-Metalhydrate batteries is researched.

- It has been demonstrated that accurate results can be obtained by applying the DiBu-model for some various load profiles. However, the performance of the model for more different load profiles should be investigated. Examples of such profiles are profiles where the battery operates near or on its operating limits, profiles where the battery operates well beyond or 
below room temperature, or profiles of real house-loads. The effectiveness of the improvements to the $\mathrm{DiBu}$-model for reduction of the deviation between the predicted SoC and the SoC calculated from measurements, should also be evaluated for the aforementioned load profiles.

- It has been demonstrated that an integration of the model in the DEMKit smart grid simulation software yields accurate predictions for the behaviour of a Pb-acid battery in a simulated house. The model should be further integrated in HEMS's applications and practical tests of the effectiveness of the model should be done.

\section{The 16 houses case}

- The largest problem in soft-islanding neighbourhoods is the overproduction of electricity due to the CHP, and the resulting electricity export to the national grid. One solution could be the addition of electricity powered heating devices (e.g. an electrical boiler or a heat pump) to the microgrid. This allows that (part of) the electricity generated by the CHP could be used for heating. In this way a better balance could be reached between heat directly generated by the CHP, and heat generated via electricity from the CHP, which may lead to lower electricity overproduction and lower fuel usage by the CHP, as less heat has to be produced directly by the CHP. Alternatively, the export of electricity could be reduced by investigating the effect of adding electric vehicles that charge the excess electricity produced by the CHP.

- The determination of the optimal size of the equipment in the neighbourhood was carried out by simulating the neighbourhood for a set of parameters (e.g. battery size and PV-panel area), and subsequently evaluating the effects of different parameters for the equipment manually. This process could be automated by including a local search over the parameter space using the simulation carried out by DEMKit itself as a function evaluation. If proper boundary conditions are applied this should yield a near optimal size for all equipment.

- It has been demonstrated that the methodology of soft-islanding neighbourhoods and simultaneous sizing of the necessary equipment leads to interesting and useful insights on the technical feasibility of different configurations of a neighbourhood multi-energy system. This process could be expanded to include the various costs (investment, installation, etc.) and benefits of the equipment to yield a financially optimal equipment size. From this, e.g. the increase in DoA related to an increase in equipment costs is valuable information for investors and other executives. Additionally a sensitivity analysis of the configuration parameters should be performed, to determine which parameters have the most influence on the final results. 
- Only short-term objectives and planning have been applied in the simulations (i.e. optimizing for the next two days using a receding horizon). However, with seasonal storage possibilities (e.g. a heat buffer), long-term objectives may be included and may result in a better performance during challenging days with little generation.

- The research relating to the 16 houses case mostly has been technologically oriented. However, also challenges in the field of economics, sociology and lawmaking remain. For example, future research should be conducted on a fair and accepted reward mechanism where participants are rewarded appropriately for helping the local community.

\section{The Seasalt Battery}

- For the cell-casing design a trade-off was made between battery performance and overall costs. Future research should be dedicated to improve the battery performance without effecting the overall costs significantly.

- In practical tests the compatibility of the Seasalt battery and the inverter poses problems. These problems should be addressed by developing a inverter designed specifically for Seasalt batteries. Additionally a battery management system should be developed to better protect the battery.

- To analyse further the deposition process of zinc at the anode of a zincbased battery, it would be very useful to perform an in-depth EIS study of the deposition process under both the reference conditions and improved conditions to get a better understanding of this process.

- The surface morphology deposited zinc layers on the anode of a zincbased battery have been studied using various analysis techniques. However, the exact composition of the layers has not been determined. The application of additional analysis techniques (e.g. X-ray diffraction, Atomic Force Microscopy and Energy Dispersive X-ray spectroscopy) may give more insight on the exact composition of the deposited layers as well the surface morphology. 


\section{A \\ CBS DATA}

In some chapters data obtained from the Centraal Bureau voor de Statistiek (CBS) was used. Although the data retrieval tool provided on their website [4] is quite comprehensive, the amount of available data is very extensive. Retrieving the exact same dataset as used here would be cumbersome, therefore the used data is included in this appendix.

Table A.1: Energy usage in the Netherlands by carrier in 2017. This data was used for the compilation of the pie-charts in Figure 1.1, the data in PJ was obtained from [4], the percentages were calculated from this data.

\begin{tabular}{|c|c|c|c|c|}
\hline \multirow{2}{*}{ Energy Carrier } & \multicolumn{2}{|c|}{ Over all } & \multicolumn{2}{|c|}{ Renewables } \\
\hline & PJ & $\%$ & PJ & $\%$ \\
\hline Natural gas & $1299 \cdot 3$ & 41.2 & & \\
\hline Oil & 1195.9 & 38.0 & & \\
\hline Coal & 383 & 12.2 & & \\
\hline Renewables & 181.7 & 5.8 & & \\
\hline Biomass & & & 123.9 & 68.2 \\
\hline Wind & & & 38 & 20.9 \\
\hline Solar & & & 9.1 & 5.0 \\
\hline Other & & & 10.7 & 5.9 \\
\hline Other & 90.6 & 2.9 & & \\
\hline Total & 3150.5 & 100 & 181.7 & 100 \\
\hline
\end{tabular}


Table A.2: Yearly energy usage in the Netherlands by carrier from 1990 to 2017. This data was used for the compilation of the stacked graph in Figure 1.2, the data was obtained from [4]

\begin{tabular}{c|cccccc}
\hline Year & \multicolumn{6}{|c}{ Energy usage [PJ/year] } \\
& Total & Natural gas & Oil & Coal & Renewables & Other \\
\hline 1990 & 2856 & 1325 & 1048.4 & 366.9 & 31.6 & 84.1 \\
1991 & 2961.5 & 1478.5 & 1034.3 & 335.6 & 32 & 81.2 \\
1992 & 2943.2 & 1439.7 & 1046.6 & 335.3 & 33 & 88.6 \\
1993 & 3008.8 & 1480.7 & 1060.1 & 336.6 & 35.3 & 96.2 \\
1994 & 3014.4 & 1430 & 1082.5 & 367.2 & 35.5 & 99.3 \\
1995 & 3094.1 & 1468.9 & 1109 & 373.6 & 39 & 103.8 \\
1996 & 3275.8 & 1627.9 & 1134.5 & 361.1 & 44.7 & 107.5 \\
1997 & 3162 & 1525.3 & 1136.2 & 351.7 & 48.5 & 100.4 \\
1998 & 3171.3 & 1506.2 & 1144.8 & 357.9 & 51.1 & 111.3 \\
1999 & 3123.5 & 1471.6 & 1149.8 & 312.3 & 53.3 & 136.5 \\
2000 & 3145.5 & 1475.7 & 1150.7 & 325.2 & 57.1 & 136.8 \\
2001 & 3220.1 & 1505.5 & 1176.9 & 346.2 & 59.9 & 131.6 \\
2002 & 3243.1 & 1490.3 & 1208.9 & 348 & 65.8 & 130.1 \\
2003 & 3355.6 & 1500.6 & 1295.1 & 359.3 & 64.4 & 136.2 \\
2004 & 3394.5 & 1536.4 & 1296.6 & 354.6 & 76.1 & 130.7 \\
2005 & 3366.2 & 1492.4 & 1292.6 & 338.6 & 95.3 & $147 \cdot 3$ \\
2006 & 3309.5 & 1433.1 & 1302.9 & 323.9 & 101.7 & 147.9 \\
2007 & 3306.7 & 1397 & 1311.3 & 351.8 & 105.9 & 140.7 \\
2008 & 3276.9 & 1454 & 1227.2 & 333.5 & 127.1 & 135.1 \\
2009 & 3243.4 & 1488.9 & 1202.9 & 312.4 & 140.2 & 99 \\
2010 & 3474.7 & 1683.3 & 1251.8 & 315.5 & 137.4 & 86.7 \\
2011 & 3239.2 & 1473.4 & 1201 & 311.4 & 143.1 & 110.3 \\
2012 & 3250.9 & 1414.2 & 1212.1 & 341.2 & 151.2 & 132.3 \\
2013 & 3183.7 & 1408 & 1149.6 & 342.8 & 149.7 & 133.6 \\
2014 & 3039.7 & 1241 & 1138.9 & 378.8 & 150.3 & 130.8 \\
2015 & 3107.8 & 1226.9 & 1143.7 & 461.1 & 159.8 & 116.3 \\
2016 & 3144.3 & 1265.5 & 1181.9 & 427.3 & 164.9 & 104.7 \\
2017 & 3150.5 & 1299.3 & 1195.9 & 383 & 181.7 & 90.6 \\
\hline & & & & & &
\end{tabular}




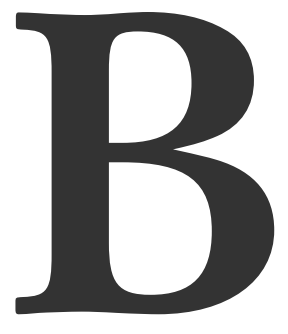

\section{The DiBu-Model}

In this appendix additional data, graphs and results related to Chapters 2 and 5 are presented.

\section{B.1 KiBAM MODEL PARAMETERS}

Table B.1: Characteristics and parameters of the KiBaM model determined for the three test batteries.

\begin{tabular}{lccc}
\hline & Conrad & Yuasa & Multipower \\
\hline Rated capacity (Ah) & 7.2 & 7.0 & 7.0 \\
Nominal voltage (V) & 6.0 & 6.0 & 6.0 \\
C (As) & $2.592 \times 10^{-5}$ & $2.520 \times 10^{-5}$ & $2.520 \times 10^{-5}$ \\
k' $\left.^{\prime}-\right)$ & 0.664 & 1.105 & 0.211 \\
c (-) & 0.013 & 0.008 & 0.050 \\
\hline
\end{tabular}

\section{B.2 VOLTAGE PREDICTIONS}

Although the voltage prediction is an important step in the application of the DiBu-model, the results of this step are only an intermediate result in the main goal of the model; the state of charge prediction. The voltage prediction step is explained in Section 2.4 and has only been demonstrated on one of the tested lead-acid batteries (the Conrad battery) in Section 2.5. However, the results of the voltage prediction for the other tested batteries were omitted from the main text, these results are presented here: 

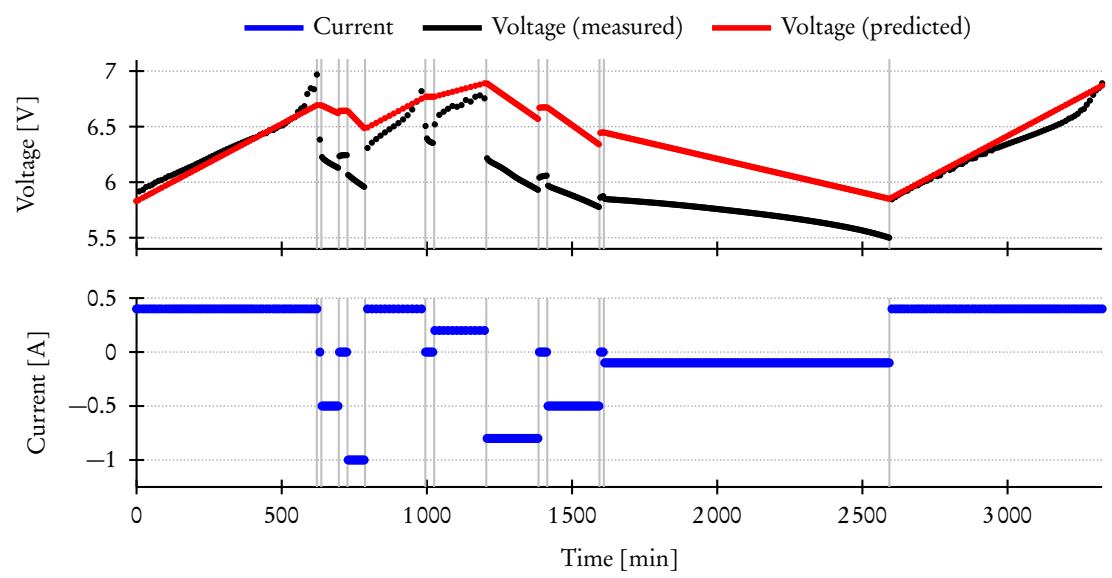

Figure B.1: The applied current and resulting voltage during the test corresponding to Table 2.2 and Figure $2.11 \mathrm{~b}$ on the Yuasa battery. The vertical lines represent the moment of step-change.
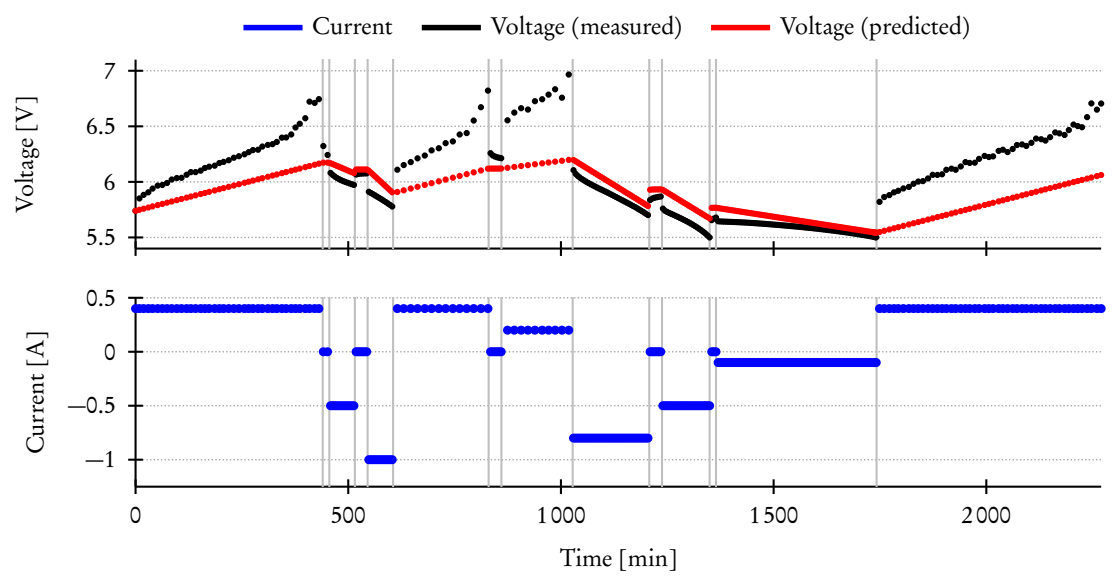

Figure B.2: The applied current and resulting voltage during the test corresponding to Table 2.2 and Figure 2.11c on the Multipower battery. The vertical lines represent the moment of step-change. 


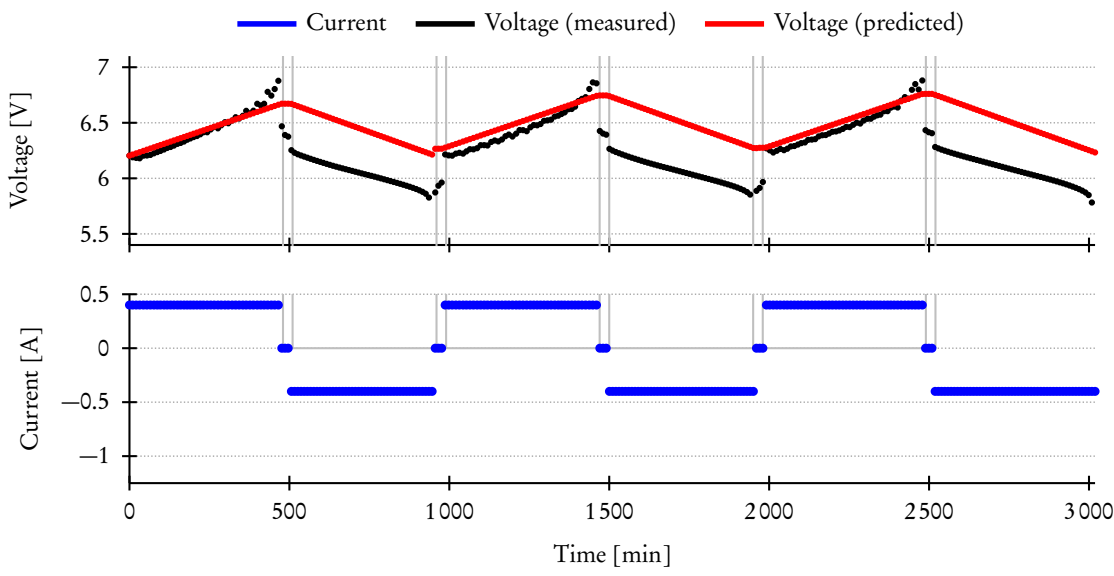

Figure B.3: The applied current and resulting voltage during the cycle-test corresponding to Table 2.3 and Figure 2.12 on the Conrad battery. The vertical lines represent the moment of step-change.
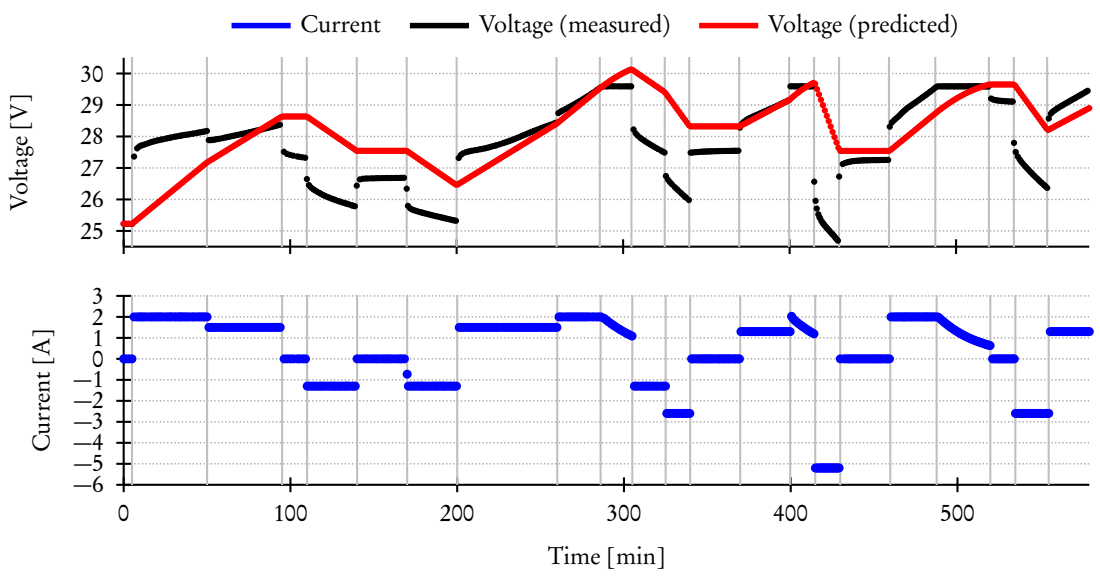

Figure B.4: The applied current and resulting voltage during the test corresponding to Table 2.5 and Figure 2.15 on the Li-Poly battery. Thevertical lines represent the moment of step-change. 

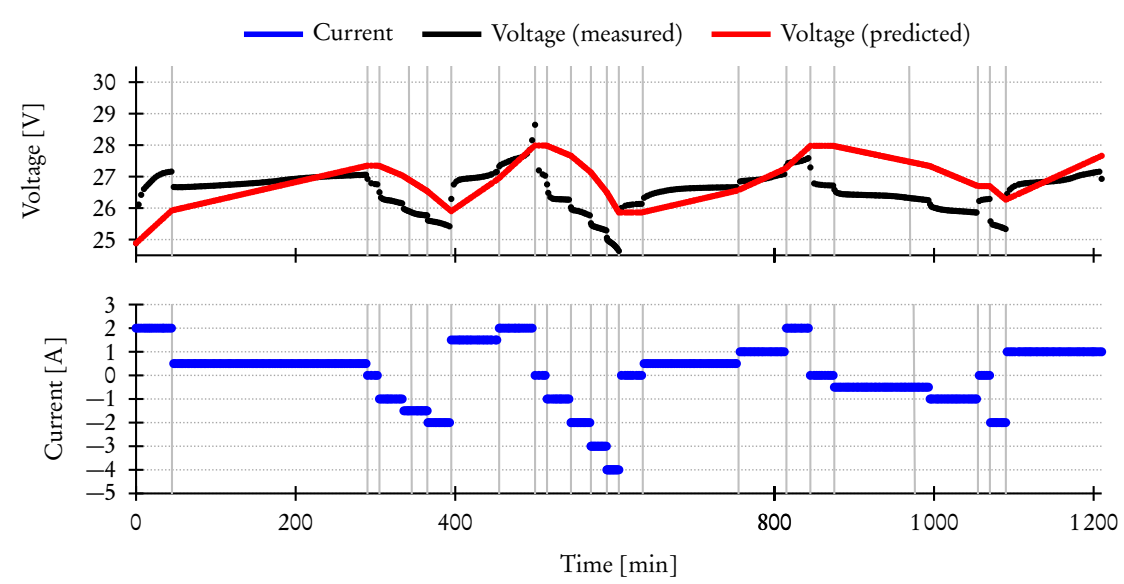

Figure B.5: The applied current and resulting voltage during the test corresponding to Table 2.6 and Figure 2.16 on the LiFePo battery. The vertical lines represent the moment of step-change. 


\section{B.3 Tabulated Results}

In the main text the SoC predicted using the $\mathrm{DiBu}$-model is often compared to the $\mathrm{SoC}$ calculated from measurements, to the SoC predicted using the $\mathrm{KiBaM}$ model (only for lead-acid batteries) and to the SoC predicted using the $\mathrm{DiBu}$ model with some improvements in place. Although the results are presented in graphs and are numerically discussed in the text, it could be difficult to distinguish the difference between some of the compared results. Therefore the results are also tabulated here. Note that the caption of each table references the related graphs.

Table B.2: Maximum difference between the predicted SoC and the SoC calculated from measurements (in \%) for the Conrad, Yuasa and Multipower batteries. Corresponds to Figures 2.11a, 2.11b and 2.11c.

\begin{tabular}{|c|c|c|c|c|c|c|}
\hline \multirow[t]{3}{*}{ Step \# } & \multicolumn{6}{|c|}{ Maximum deviation from measured value (\%) } \\
\hline & \multicolumn{2}{|c|}{ Conrad } & \multicolumn{2}{|c|}{ Yuasa } & \multicolumn{2}{|c|}{ Multipower } \\
\hline & DiBu-model & KiBaM model & DiBu-model & KiBaM model & DiBu-model & KiBaM model \\
\hline 1 & 0.9 & 4.1 & 0.4 & 2.6 & 1.9 & 1.6 \\
\hline 2 & 0.9 & 4.1 & 0.0 & 2.6 & 1.9 & 1.6 \\
\hline 3 & 1.4 & 4.1 & 0.5 & 2.6 & 2.1 & 1.7 \\
\hline 4 & 1.4 & $3 \cdot 9$ & 0.5 & 2.3 & 2.1 & 1.7 \\
\hline 5 & 2.3 & 3.9 & 1.8 & 2.3 & 2.5 & 2.0 \\
\hline 6 & 2.5 & 5.5 & 1.8 & 4.1 & 3.6 & 3.2 \\
\hline 7 & 2.5 & 5.5 & 1.5 & 4.1 & 3.6 & 3.2 \\
\hline 8 & 2.6 & 6.5 & 1.5 & 5.1 & $4 \cdot 3$ & 4.1 \\
\hline 9 & 5.1 & 6.5 & 4.8 & 5.1 & $5 ., 0$ & 4.8 \\
\hline 10 & 5.1 & 5.8 & 4.8 & $4 \cdot 3$ & 5.0 & 4.8 \\
\hline 11 & 6.7 & 6.2 & 6.9 & 4.6 & 5.5 & 5.8 \\
\hline 12 & 6.7 & 6.2 & 6.9 & 4.6 & 5.5 & 5.8 \\
\hline 13 & 8.1 & $7 \cdot 7$ & 8.4 & 5.6 & 6.1 & 6.9 \\
\hline 14 & 12.1 & 11.9 & 8.5 & 9.0 & 9.7 & 8.8 \\
\hline
\end{tabular}


Table B.3: Maximum difference between the predicted SoC and the SoC calculated from measurements (in \%) for the charge / discharge cycle scenario for the Conrad battery. Corresponds to Figure 2.12

\begin{tabular}{|c|c|c|}
\hline \multirow[t]{2}{*}{ Step \# } & \multicolumn{2}{|c|}{$\begin{array}{l}\text { Maximum deviation from } \\
\text { measured value (\%) }\end{array}$} \\
\hline & DiBu-model & KiBaM model \\
\hline 1 & 0.2 & $3 \cdot 3$ \\
\hline 2 & 0.1 & $3 \cdot 3$ \\
\hline 3 & 3.2 & 3.4 \\
\hline 4 & 3.2 & 3.4 \\
\hline 5 & 3.2 & 6.7 \\
\hline 6 & 2.7 & 6.7 \\
\hline 7 & 6.4 & 6.7 \\
\hline 8 & 6.4 & 6.7 \\
\hline 9 & 6.4 & 10.2 \\
\hline 10 & 5.9 & 10.2 \\
\hline 11 & 9.7 & 10.2 \\
\hline
\end{tabular}

Table B.4: Influence of the value of parameters $\alpha, \beta, \gamma$ and $\delta$ on the accuracy of the predicted SoC for the Conrad, Yuasa and Multipower batteries.

\begin{tabular}{|c|c|c|c|c|c|c|}
\hline \multirow{3}{*}{$\begin{array}{l}\text { Changed } \\
\text { parameter }\end{array}$} & \multicolumn{6}{|c|}{ Deviation from measured value (\%) } \\
\hline & \multicolumn{2}{|c|}{ Conrad } & \multicolumn{2}{|c|}{ Yuasa } & \multicolumn{2}{|c|}{ Multipower } \\
\hline & Over-all & Maximum & Over-all & Maximum & Over-all & Maximum \\
\hline none & 12.1 & 13.7 & 8.5 & 10.9 & 9.7 & 7.0 \\
\hline$\alpha+10 \%$ & 12.7 & 13.0 & 8.3 & 10.4 & 10.0 & 6.7 \\
\hline$\beta+10 \%$ & 12.2 & 13.6 & 8.4 & 10.9 & 9.8 & 6.9 \\
\hline$\gamma+10 \%$ & 12.1 & 13.7 & 8.5 & 10.9 & $9 \cdot 7$ & 7.0 \\
\hline$\delta+10 \%$ & 12.6 & 13.1 & 8.5 & 10.3 & 10.0 & 6.8 \\
\hline all $+10 \%$ & $13 \cdot 3$ & 12.4 & $9 \cdot 3$ & 9.6 & 10.5 & 6.5 \\
\hline$\alpha-10 \%$ & 11.5 & $14 \cdot 3$ & 9.1 & 11.5 & $9 \cdot 3$ & 7.2 \\
\hline$\beta-10 \%$ & 12.0 & 13.8 & 8.5 & 11.0 & $9 \cdot 5$ & 7.0 \\
\hline$\gamma-10 \%$ & 12.1 & 13.7 & 8.5 & 10.9 & $9 \cdot 7$ & 7.0 \\
\hline$\delta-10 \%$ & 11.6 & $14 \cdot 3$ & 9.6 & 11.8 & 9.2 & 7.1 \\
\hline all - $10 \%$ & 10.9 & 15.0 & 10.4 & 12.5 & 8.8 & $7 \cdot 4$ \\
\hline
\end{tabular}


Table B.5: Maximum difference between the predicted SoC and the SoC calculated from measurements (in \%) for the Conrad, Yuasa and Multipower batteries, applying the improvements. Corresponds to Figures 2.13a, 2.13b and 2.13c.

\begin{tabular}{ccccccc}
\hline Step \# & \multicolumn{6}{c}{ Maximum deviation from measured value (\%) } \\
\hline \multicolumn{7}{c}{ Conrad } \\
& DiBu-model & Improvements & DiBu-model & Improvements & DiBu-model & Improvements \\
\hline 1 & 0.9 & 0.9 & 0.4 & 0.4 & 1.9 & 1.9 \\
2 & 0.9 & 0.9 & 0.0 & 0.0 & 1.9 & 1.9 \\
3 & 1.4 & 1.4 & 0.5 & 0.5 & 2.1 & 2.1 \\
4 & 1.4 & 0.0 & 0.5 & 0.0 & 2.1 & 0.0 \\
5 & 2.3 & 0.9 & 1.8 & 1.3 & 2.5 & 0.3 \\
6 & 2.5 & 0.8 & 1.8 & 0.7 & 3.6 & 0.9 \\
7 & 2.5 & 0.8 & 1.5 & 0.7 & 3.6 & 0.8 \\
8 & 2.6 & 1.1 & 1.5 & 1.0 & 4.3 & 1.4 \\
9 & 5.1 & 2.8 & 4.8 & 2.7 & 5.0 & 2.6 \\
10 & 5.1 & 0.0 & 4.8 & 0.0 & 5.0 & 0.0 \\
11 & 6.7 & 1.1 & 6.9 & 1.1 & 5.5 & 0.8 \\
12 & 6.7 & 0.0 & 6.9 & 0.0 & 5.5 & 0.0 \\
13 & 8.1 & 1.2 & 8.4 & 0.6 & 6.1 & 0.8 \\
14 & 12.1 & 0.5 & 8.5 & 0.5 & 9.7 & 2.1 \\
\hline
\end{tabular}


Table B.6: Maximum difference between the predicted SoC and the SoC calculated from measurements (in \%) for the Li-Poly and LiFePo batteries, applying the improvements. Corresponds to Figures 2.15 and 2.16.

\begin{tabular}{ccccc}
\hline Step \# & \multicolumn{4}{c}{ Maximum deviation from measured value (\%) } \\
\hline \multicolumn{5}{c}{ Li-Poly } \\
DiBu-model & Improvements & DiBu-model & Improvements \\
\hline 1 & 0.0 & 0.0 & 1.8 & 1.8 \\
2 & 0.3 & 0.3 & 2.1 & 2.1 \\
3 & 1.9 & 1.9 & 2.1 & 2.1 \\
4 & 1.9 & 1.9 & 2.7 & 2.7 \\
5 & 0.0 & 0.0 & 4.1 & 0.0 \\
6 & 0.0 & 0.0 & 4.7 & 0.2 \\
7 & 1.6 & 1.0 & 5.3 & 0.3 \\
8 & 0.3 & 2.4 & 5.1 & 0.3 \\
9 & 0.8 & 3.3 & 5.1 & 0.3 \\
10 & 2.0 & 4.8 & 6.1 & 0.8 \\
11 & 0.7 & 3.2 & 7.2 & 0.1 \\
12 & 1.7 & 1.1 & 8.4 & 0.1 \\
13 & 1.7 & 0.0 & 9.7 & 0.7 \\
14 & 0.7 & 0.6 & 9.7 & 0.0 \\
15 & 0.9 & 1.9 & 9.8 & 1.1 \\
16 & 4.3 & 2.5 & 9.4 & 1.8 \\
17 & 4.3 & 0.0 & 8.8 & 2.2 \\
18 & 3.6 & 0.1 & 8.8 & 2.2 \\
19 & 1.3 & 2.0 & 10.1 & 2.5 \\
20 & 1.3 & 2.0 & 11.2 & 0.0 \\
21 & 3.9 & 0.1 & 11.2 & 0.0 \\
22 & 3.3 & 0.6 & 11.8 & 0.3 \\
23 & & & 11.6 & 0.4 \\
\hline & & & &
\end{tabular}


Table B.7: Maximum difference between the predicted SoC and the SoC calculated from measurements (in \%) for the Seasalt battery. Corresponds to Figure 5.10.

\begin{tabular}{|c|c|c|}
\hline \multirow[t]{2}{*}{ Step \# } & \multicolumn{2}{|c|}{$\begin{array}{l}\text { Maximum deviation from } \\
\text { measured value }(\%)\end{array}$} \\
\hline & DiBu-model & Improvements \\
\hline 1 & 0.5 & 0.5 \\
\hline 2 & 1.6 & 1.6 \\
\hline 3 & 1.1 & 0.5 \\
\hline 4 & 1.9 & 3.4 \\
\hline 5 & 2.0 & 0.1 \\
\hline 6 & 2.9 & 1.0 \\
\hline 7 & 3.1 & 1.2 \\
\hline 8 & 2.2 & 4.1 \\
\hline 9 & 2.1 & 0.1 \\
\hline 10 & 2.1 & 0.2 \\
\hline 11 & 3.6 & 1.4 \\
\hline
\end{tabular}




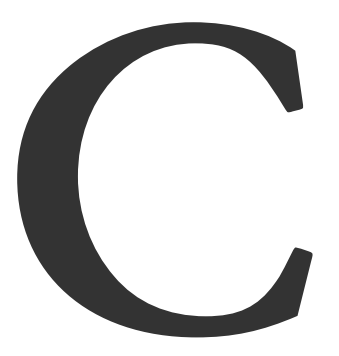

\section{The 16 houses Case}

In this appendix additional data and results related to Chapter 4 are presented.

Table C.1: Largest electricity imports and exports and total electricity import in weeks $\mathrm{A}$ and $\mathrm{B}$ in the greenfields neighbourhood for various battery sizes.

\begin{tabular}{cccc}
\hline Battery Size $[\mathrm{kWh}]$ & Largest export $[\mathrm{kW}]$ & Largest import $[\mathrm{kW}]$ & Total import $[\mathrm{kWh}]$ \\
\hline Week $A$ & & & \\
\hline 2 & 39.4 & 7.7 & 0.44 \\
2.5 & 37.5 & 6.5 & 0.29 \\
3 & 36.0 & 3.9 & 0.07 \\
3.5 & 34.7 & 3.0 & 0.07 \\
4 & 33.5 & 10.5 & 0.37 \\
4.5 & 32.3 & 5.8 & 0.08 \\
5 & 31.2 & 7.2 & 0.23 \\
5.5 & 30.1 & 1.0 & 0.01 \\
6 & 29.0 & 1.0 & 0.01 \\
\hline Week $B$ & & & \\
\hline 2 & 22.0 & 8.1 & 3.42 \\
2.5 & 20.4 & 7.1 & 2.60 \\
3 & 21.7 & 5.2 & 1.88 \\
3.5 & 20.6 & 3.8 & 1.28 \\
4 & 18.8 & 5.5 & 1.00 \\
4.5 & 17.6 & 4.4 & 0.77 \\
5 & 16.2 & 3.5 & 0.54 \\
5.5 & 15.2 & 4.2 & 0.47 \\
6 & 14.1 & 3.3 & 0.38 \\
\hline
\end{tabular}


Table C.2: Largest electricity imports and exports and total electricity import in week A in the Markluiden neighbourhood for various PV-panel areas.

\begin{tabular}{cccc}
\hline PV-panel area $\left[\mathrm{m}^{2}\right]$ & Largest export $[\mathrm{kW}]$ & Largest import $[\mathrm{kW}]$ & Total import $[\mathrm{kWh}]$ \\
\hline 8 & 12.2 & 3.7 & 263.7 \\
12 & 13.2 & 6.0 & 100.2 \\
16 & 13.7 & 9.5 & 66.5 \\
20 & 12.2 & 13.3 & 51.0 \\
24 & 12.2 & 15.1 & 37.5 \\
\hline
\end{tabular}

Table C.3: Largest electricity imports and exports and total electricity import in week $\mathrm{A}$ in the Markluiden neighbourhood for various battery sizes.

\begin{tabular}{cccc}
\hline Battery Size $[\mathrm{kWh}]$ & Largest export $[\mathrm{kW}]$ & Largest import $[\mathrm{kW}]$ & Total import $[\mathrm{kWh}]$ \\
\hline 3 & 25.3 & 12.2 & 134.5 \\
4 & 22.7 & 13.7 & 82.2 \\
5 & 21.4 & 12.2 & 75.5 \\
6 & 18.6 & 12.2 & 62.3 \\
7 & 16.4 & 12.2 & 63.7 \\
9 & 12.7 & 12.2 & 56.1 \\
11 & 12.4 & 12.2 & 52.3 \\
13.5 & 13.0 & 12.2 & 53.9 \\
\hline
\end{tabular}




\section{Acronyms}

$\begin{array}{lll}\text { A } & \text { ALPG } & \text { Artificial Load Profile Generator } \\ & \text { ATES } & \text { Aquifier Thermal Energy Storage } \\ \text { B } & \text { BMS } & \text { Battery Management System }\end{array}$


182 


\section{BibliograPHY}

[1] United Nations Framework Convention on Climate Change. The paris agreement. [Online] Available: https://unfccc.int, 2015. Last accessed on 11-6-2019. (Cited on pages 1 and 3 ).

[2] Klimaatberaad. Ontwerp van het klimaatakkoord. [Online] Available: https://www.klimaatakkoord.nl, 2018. Last accessed on 13-6-2019. (Cited on pages 1,4 , and 11 ).

[3] Ministerie van Economische Zaken. Energieagenda - Naar een $\mathrm{CO}_{2}$ arme energievoorziening, 2016. (Cited on pages 1 and 64).

[4] CBS Statline. Energiebalans; aanbod en verbruik, sector. [Online] Available: https://opendata.cbs.nl, 2017. Last accessed on 18-6-2019. (Cited on pages 2, 7, 163 , and 164).

[5] M. Guo, W. Song, and J. Buhain. Bioenergy and biofuels: History, status, and perspective. Renewable and Sustainable Energy Reviews, 42:712-725, 2015. doi: 10.1016/j.rser.2014.10.013. (Cited on page 2).

[6] C. Cambero and T. Sowlati. Assessment and optimization of forest biomass supply chains from economic, social and environmental perspectives - a review of literature. Renewable and Sustainable Energy Reviews, 36:62-73, 2014. doi: 10.1016/j.rser.2014.04.041. (Cited on page 2).

[7] ECN, Energie-Nederland, and Netbeheer Nederland. Energietrends, 2016. (Cited on pages 3 and 64 ).

[8] Netbeheer Nederland. Net voor de toekomst - Een vooruitblik op de energievoorziening in 2050, 2017. (Cited on pages 3 and 64).

[9] Netbeheer Nederland. Grids for the future - A look ahead towards the energy supply in 2050, 2017. (Cited on pages 3 and 64).

[10] SER. Energieakkoord voor duurzame groei. [Online] Available: https://www.energieakkoordser.nl, 2013. Last accessed on 18-6-2019. (Cited on page 3).

[11] Royal Haskoning DHV. Onderzoek potentie energie uit waterkracht in provincie gelderland. [Online] Available: https://www.geldersenergieakkoord.nl, 2016. Last accessed on 18-6-2019. (Cited on page 3). 
[12] M. M. Fouad, L. A. Shihata, and E. I. Morgan. An integrated review of factors influencing the perfomance of photovoltaic panels. Renewable and Sustainable Energy Reviews, 80:1499-1511, 2017. doi: 10.1016/j.rser.2017.05.141. (Cited on page 4).

[13] M. E. Meral and F. Dinçer. Renewable and Sustainable Energy Reviews, 15(5): 2176-2184, 2011. doi: 10.1016/j.rser.2011.01.010. (Cited on page 4).

[14] Average yearly energy usage. [Online] Available: https://www.energiesite.nl, 2019. Last accessed on 21-11-2019. (Cited on pages 5 and 84).

[15] B Dunn, H Kamath, and J-M Tarascon. Electrical energy storage for the grid: A battery of choices. Science, 334(18):928-935, 2011. doi: 10.1126/science.1212741. (Cited on pages 6, 11, and 12).

[16] S Nykamp. Integrating Renewables in Distribution Grids: Storage, regulation and the interaction of different stakeholders in future grids. PhD thesis, University of Twente, 2013. (Cited on page 6).

[17] B. Lasseter. Microgrids [distributed power generation]. In 2001 IEEE Power Engineering Society Winter Meeting. Conference Proceedings (Cat. No.01 $\mathrm{CH}_{37194}$ ), volume 1, pages 146-149, 2001. doi: 10.1109/PESW.2001.917020. (Cited on pages 7 and 64).

[18] A. Hirsch, Y. Parag, and J. Guerrero. Microgrids: A review of technologies, key drivers, and outstanding issues. Renewable and Sustainable Energy Reviews, 90: 402-411, 2018. doi: 10.1016/j.rser.2018.03.040. (Cited on pages 7 and 8).

[19] B. Zhou, W. Li, K. W. Chan, Y. Cao, Y. Kuang, X. Liu, and X. Wang. Smart home energy management systems: Concept, configurations, and scheduling strategies. Renewable and Sustainable Energy Reviews, 61:30-40, 2016. doi: 10.1016/j.rser.2016.03.047. (Cited on page 9).

[20] G. Hoogsteen. A Cyber-Physical Systems Perspective on Decentralized Energy Management. $\mathrm{PhD}$ thesis, University of Twente, 2017. (Cited on pages 9, 10, 17, 48, 50, 51, 69, 70, 72, 97, and 125).

[21] M. E. T. Gerards, H. A. Toersche, G. Hoogsteen, T. van der Klauw, J. L. Hurink, and G. J. M. Smit. Demand side management using profile steering. In IEEE Powertech 2015, pages 1-6, 2015. doi: 10.1109/ptc.2015.7232328. (Cited on pages 10, $17,50,51,54,65,70,73$, and 74 ).

[22] J. Pascual, J. Barricarte, P. Sanchis, and L. Marroyo. Energy management strategy for a renewable-based residential microgrid with generation and demand forecasting. Applied Energy, 158:12-25, 2015. doi: 10.1016/j.apenergy.2015.08.040. (Cited on page 10).

[23] L. Olatomiwa, S. Mekhilef, M.S. Ismail, and M. Moghavvemi. Energy management strategies in hybrid renewable energy systems: A review. Renewable and Sustainable Energy Reviews, 62:821-835, 2016. doi: 10.1016/j.rser.2016.05.040. (Cited on page 10). 
[24] A.A. Khodadoost Arani, G.B. Gharehpetian, and M. Abedi. Review on energy storage systems control methods in microgrids. International Journal of Electrical Power E Energy Systems, 107:745-757, 2019. doi: 10.1016/j.ijepes.2018.12.040. (Cited on page 10).

[25] Vereniging Aardehuis. [Online] Available: http://aardehuis.nl, 2019. Last accessed on 24-10-2019. (Cited on page 10).

[26] Gridflex Heeten. [Online] Available: https://gridflex.nl, 2019. Last accessed on 14-11-2019. (Cited on pages 10 and 124).

[27] S. Upadhyay and M.P. Sharma. A review on configurations, control and sizing methodologies of hybrid energy systems. Renewable and Sustainable Energy Reviews, 38:47-63, 2014. doi: 10.1016/j.rser.2014.05.057. (Cited on page 10).

[28] M Faisal, M. A. Hannan, P. J. Ker, A. Hussain, M. B. Mansor, and F. Blaabjerg. Review of energy storage system technologies in microgrid applications: Issues and challenges. IEEE Access, 6:35143-35164, 2018. doi: 10.1109/access.2018.2841407. (Cited on page 10).

[29] R. P. van Leeuwen. Towards $100 \%$ renewable energy supply for urban areas and the role of smart control. PhD thesis, University of Twente, 2017. (Cited on pages 11, 69,73 , and 100).

[30] M. Aneke and M. Wang. Energy storage technologies and real life applications - a state of the art review. Applied Energy, 179:350-377, 2016. doi: 10.1016/j.apenergy.2016.06.097. (Cited on page 11).

[31] R. Amirante, E. Cassone, E. Distaso, and P. Tamburrano. Overview on recent developments in energy storage: Mechanical, electrochemical and hydrogen technologies. Energy Conversion and Management, 132:372-387, 2017. doi: 10.1016/j.enconman.2016.11.046. (Not cited).

[32] T.M.I. Mahlia, T.J. Saktisahdan, A. Jannifar, M.H. Hasan, and H.S.C. Matseelar. A review of available methods and development on energy storage; technology update. Renewable and Sustainable Energy Reviews, 33:532-545, 2014. doi: 10.1016/j.rser.2014.01.068. (Not cited).

[33] A. Castillo and D.F. Gayme. Grid-scale energy storage applications in renewable energy integration: A survey. Energy Conversion and Management, 87:885-894, 2014. doi: 10.1016/j.enconman.2014.07.063. (Cited on pages 11 and 114).

[34] D. Larcher and J-M. Tarascon. Towards greener and more sustainable batteries for electrical energy storage. Nature Chemistry, 7:19-29, 2015. doi: 10.1038/nchem.2085. (Cited on pages 11 and 108).

[35] N. Günter and A. Marinopoulos. Energy storage for grid services and applications: Classification, market review, metrics, and methodology for evaluation of deployment cases. Journal of Energy Storage, 8:226-234, 2016. doi: 10.1016/j.est.2016.08.011. (Cited on page 11).

[36] M. R. Jongerden and B. R. Haverkort. Which battery model to use? Software, IET, 3(6):445-457, 2009. doi: 10.1049/iet-sen.2009.0001. (Cited on pages 11 and 16). 
[37] T. Gao, Wang Z., S. Chen, and L. Guo. Hazardous characteristics of charge and discharge of lithium-ion batteries under adiabatic environment and hot environment. International Journal of Heat and Mass Transfer, 141:419-431, 2019. doi: 10.1016/j.ijheatmasstransfer.2019.06.075. (Cited on pages 12 and 108).

[38] A. Börger, J. Mertens, and H. Wenzl. Thermal runaway and thermal runaway propagation in batteries: What do we talk about? Journal of Energy Storage, 24: 100649, 2019. doi: 10.1016/j.est.2019.01.012. (Cited on pages 12 and 108).

[39] Dr Ten B.V. [Online] Available: https://www.drten.nl, 2019. Last accessed on 4-11-2019. (Cited on page 12).

[40] B. P. Roberts and C. Sandberg. The role of energy storage in development of smart grids. Proceedings of the IEEE, 99(6):1139-1144, 2011. doi: 10.1109/jproc.2011.2116752. (Cited on page 16).

[41] G. Hoogsteen, A. Molderink, J. L. Hurink, G. J. M. Smit, F. Schuring, and B. Kootstra. Impact of peak electricity demand in distribution grids: A stress test. In IEEE Powertech 2015, pages 1-6, 2015. doi: 10.1109/ptc.2015.7232412. (Cited on pages 16 and 66).

[42] V. M. M. J. Reijnders, M. E. T. Gerards, and J. V. Hurink. Pricing mechanism based on losses using grid topology. In 2019 IEEE Milan PowerTech, pages 1-6, 2019. doi: 10.1109/PTC.2019.8810436. (Cited on pages 16 and 125).

[43] W-Y. Chang. The state of charge estimating methods for battery: a review. ISRN Applied Mathematics, pages 1-7, 2013. doi: 10.1155/2013/953792. (Cited on page 16).

[44] R.Dufo-López, J. M. Lujano-Rojas, and J. L. Bernal-Agustín. Comparison of different lead-acid battery lifetime prediction models for use in simulation of stand-alone photovoltaic systems. Applied Energy, 115:242-253, 2014. doi: 10.1016/j.apenergy.2013.11.021. (Cited on page 16).

[45] J. Schiffer, D. U. Sauer, H. Bindner, T. Cronin, P. Lundsager, and R. Kaiser. Model prediction for ranking lead-acid batteries according to expected lifetime in renewable energy systems and autonomous power-supply systems. Journal of Power sources, 168:66-78, 2007. doi: 10.1016/j.jpowsour.2006.11.092. (Cited on pages 16 and 48 ).

[46] J. F. Manwell and J. G. McGowan. Lead acid battery storage model for hybrid energy systems. Solar Energy, 50(5):399-405, 1993. doi: 10.1016/0038-092x(93)900602. (Cited on pages 16, 33, and 48).

[47] F. Husnayain, A. R. Utomo, and P. S. Priambodo. State of charge estimation for a lead-acid battery using backpropagation neural network method. In IEEE International Conference on Electrical Engineering and Computer Science, pages 274-278, 2014. doi: 10.1109/iceecs.2014.7045261. (Cited on page 16).

[48] H. He, R. Xiong, and J. Fan. Evaluation of lithium-ion battery equivalent circuit models for state of charge estimation by an experimental approach. Energies, 4: 582-598, 2011. doi: 10.3390/en4040582. (Cited on page 16). 
[49] M. Doyle, T. F. Fuller, and J. Newman. Modeling of galvanostatic charge and discharge of the lithium/polymer/insertion cell. Journal of the Electrochemical Society, 140(6):1526-1533, 1993. doi: 10.1149/1.2221597. (Cited on pages 16 and 48).

[50] P. Satyam. Impact of vehicle charge and discharge cycles on the thermal characteristics of lithium-ion batteries. Master's thesis, University of Waterloo, 2014 (Cited on page 16).

[51] S. Panchal, J. Mcgrory, J. Kong, R. Fraser, M. Fowler, I. Dincer, and M. AgelinChaab. Cycling degradation testing and analysis of a lifepo4 battery at actual conditions. International Journal of Energy Research, 41(15):2565-2575, 2017. doi: 10.1002/er.3837. (Cited on page 16).

[52] X. Hu, S. Li, and H. Peng. A comparative study of equivalent circuit models for li-ion batteries. Journal of Power Sources, 198:359-367, 2012. doi: 10.1016/j.jpowsour.2011.10.013. (Cited on page 16).

[53] K. S. Ng, C. S. Moo, Y. P. Chen, and Y. C. Hsieh. Enhanced coulomb counting method for estimating state-of-charge and state-of-health of lithium-ion batteries. Applied Energy, 86(9):1506-1511, 2009. doi: 10.1016/j.apenergy.2008.11.021. (Cited on pages 16 and 33 ).

[54] E. Koliou, C. Eid, J. P. Chaves-Ávila, and R. A. Hakvoort. Demand response in liberalized electricity markets: Analysis of aggregated load participation in the german balancing mechanism. Energy, 71(Supplement C):245-254, 2014. doi: 10.1016/j.energy.2014.04.067. (Cited on page 17).

[55] Universal Smart Energy Framework. [Online] Available: https://www.usef.energy, 2017. Last accessed on 13-6-2019. (Cited on page 17).

[56] T. van der Klauw, M. E. T. Gerards, and J. L. Hurink. Resource allocation problems in decentralized energy management. OR Spectrum, 39(3):749-773, 2017. doi: 10.1007/s00291-017-0474-2. (Cited on pages 17, 48, 51, 52, and 53).

[57] T. van der Klauw, M. E. T. Gerards, G. J. M. Smit, and J. L. Hurink. Optimal scheduling of electrical vehicle charging under two types of steering signals. In IEEE PES Innovative Smart Grid Technologies, Europe, pages 1-6, 2014. doi: 10.1109/isgteurope.2014.7028746. (Cited on page 17).

[58] A. Molderink, V. Bakker, M. G. C. Bosman, J. L. Hurink, and G. J. M. Smit. Management and control of domestic smart grid technology. IEEE Transactions On Smart Grid, 1(2):109-118, 2010. doi: 10.1109/tsg.2010.2055904. (Cited on pages 17 and 65).

[59] V. Bakker. Triana: a control strategy for Smart Grids: Forecasting, planning E realtime control. PhD thesis, University of Twente, 2011. (Cited on pages 17, 67, and 73 ).

[60] K. Anderson, J. Du, A. Naryan, and A. El Gamal. Gridspice: A distributed simulation platform for the smart grid. IEEE Transactions on Industrial Informatics, 10(4):2354-2363, 2014. doi: 10.1109/tii.2014.2332115. (Cited on pages 17 and 48). 
[61] G. Hoogsteen. Demkit: A flexible smart grid simulation and demonstration platform written in python. In Proceedings of the 'Energy-Open' Workshop (WP 17-01), pages 26-27, 2017. (Cited on pages 17, 73, and 75).

[62] R. P. van Leeuwen, J. Fink, and G. J. M. Smit. Central model predictive control of a group of domestic heat pumps, case study for a small district. In Smartgreens 2015, pages 136-147, 2015. doi: 10.5220/0005434301360147. (Cited on page 17).

[63] UBA 5 battery analyzer. [Online] Available: http://www.vencon.com, 2018. Last accessed on 27-2-2018. (Cited on pages 18 and 109).

[64] Cadex. C80oo battery analyzer. [Online] Available: http://www.cadex.com, 2018. Last accessed on 27-2-2018. (Cited on pages 18 and 58 ).

[65] R. P. van Leeuwen, I. Gebhardt, J. B. de Wit, and G. J. M. Smit. A predictive model for smart control of a domestic heat pump and thermal storage. In Smartgreens 2016, pages 1-10, 2016. doi: 10.5220/0005762201360145. (Cited on page 22).

[66] D.C. Giancoli. Physics for Scientists and Engineers. Prentice Hall, 2000. ISBN 0-13-021517-1. (Cited on page 24).

[67] M. R. Palacín and A. de Guilbert. Why do batteries fail? Science, 315(6273):574, 2016. doi: 10.1126/science.1253292. (Cited on pages 25, 26, 112, and 134).

[68] Victron Energy. Multiplus battery charger / inverter. [Online] Available: https://www.victronenergy.com, 2018. Last accessed on 7-11-2018. (Cited on pages 38 and 109).

[69] P. O. Kriett and M. Salani. Optimal control of a residential microgrid. Energy, 42(1):321-330, 2012. doi: 10.1016/j.energy.2012.03.049. (Cited on page 48).

[70] A. Molderink. On the three-step control methodology for Smart Grids. PhD thesis, University of Twente, 2011. (Cited on pages 48, 67, and 73).

[71] G. Hoogsteen, A. Molderink, J. L. Hurink, and G. J. M. Smit. Generation of flexible domestic load profiles to evaluate demand side management approaches. In IEEE Energycon 2016, pages 1-6, 2016. doi: 10.1109/energycon.2016.7513873. (Cited on pages $48,53,72$, and 93).

[72] G. Hoogsteen, A. Molderink, J. L. Hurink, and G. J. M. Smit. Asynchronous event driven distributed energy management using profile steering. In IEEE Powertech 2017, pages 1-6, 2017. doi: 10.1109/ptc.2017.7980986. (Cited on pages 48 and 51).

[73] T. van der Klauw. Decentralized Energy Management with Profile Steering - Resource Allocation Problems in Energy Management. PhD thesis, University of Twente, 2017. (Cited on pages 54 and 69).

[74] P. Siano. Demand response and smart grids - A survey. Renewable and Sustainable Energy Reviews, 30:461-478, 2014. doi: 10.1016/j.rser.2013.10.022. (Cited on page 64). 
[75] K. McKenna and A. Keane. Discrete elastic residential load response under variable pricing schemes. In IEEE PES Innovative Smart Grid Technologies, Europe, pages 1-6, 2014. doi: 10.1109/isgteurope.2014.7028769. (Cited on page 64).

[76] S. Nykamp, M. G. C. Bosman, A. Molderink, J. L. Hurink, and G. J. M. Smit. Value of storage in distribution grids: competition or cooperation of stakeholders? IEEE Transactions on Smart Grid, 4(3):1361-1370, 2013. doi: 10.1109/TSG.2013.2254730. (Cited on pages 64 and 65).

[77] R. H. Lasseter. Smart Distribution: Coupled Microgrids. Proceedings of the IEEE, 99(6):1074-1082, 2011. doi: 10.1109/JPROC.2011.2114630. (Cited on page 64).

[78] D. E. Olivares, A. Mehrizi-Sani, A. H. Etemadi, C. A. Cañizares, R. Iravani, M. Kazerani, A. H. Hajimiragha, O. Gomis-Bellmunt, M. Saeedifard, R. PalmaBehnke, G. A. Jiménez-Estévez, and N. D. Hatziargyriou. Trends in microgrid control. IEEE Transactions on Smart Grid, 5(4):1905-1919, 2014. doi: 10.1109/TSG.2013.2295514. (Cited on page 64).

[79] J. M. Guerrero, M. Chandorkar, T. L. Lee, and P. C. Loh. Advanced control architectures for intelligent microgrids: part i: decentralized and hierarchical control. IEEE Transactions on Industrial Electronics, 60(4):1254-1262, 2013. doi: 10.1109/TIE.2012.2194969. (Cited on page 64).

[80] A. L. Dimeas and N. D. Hatziargyriou. Operation of a multiagent system for microgrid control. IEEE Transactions on Power Systems, 20(3):1447-1455, 2005. doi: 10.1109/TPWRS.2005.852060. (Cited on page 64).

[81] P. Mancarella. MES (multi-energy systems): An overview of concepts and evaluation models. Energy, 65(C):1-17, 2014. doi: 10.1016/j.energy.2013.11. (Cited on page 65).

[82] N. Good, E. A. Martinez Cesena, C. Heltorp, and P. Mancarella. A transactive energy modelling and assessment framework for demand response business cases in smart distributed multi-energy systems. Energy, 2018. ISSN 0360-5442. doi: 10.1016/j.energy.2018.02.089. (Cited on page 65).

[83] E. A. M. Cesena and P. Mancarella. Energy systems integration in smart districts: robust optimisation of multi-energy flows in integrated electricity, heat and gas networks. IEEE Transactions on Smart Grid, pages 1-1, 2018. doi: 10.1109/TSG.2018.2828146. (Cited on page 65).

[84] S. Long, O. Marjanovic, and A. Parisio. Demand smoothing in multi-energy systems using model predictive control. In IEEE PES Innovative Smart Grid Technologies, Europe, pages 1-6, 2018. doi: 10.1109/isgteurope.2018.8571560. (Cited on page 65$)$.

[85] K. X. Perez, M. Baldea, and T. F. Edgar. Integrated smart appliance scheduling and HVAC control for peak residential load management. In 2016 American Control Conference (ACC), pages 1458-1463, 2016. doi: 10.1109/acc.2016.7525122. (Cited on page 65$)$. 
[86] KNMI. Uurgegevens van het weer in Nederland. [Online] Available: http://www.knmi.nl, 2014. Last accessed on 27-10-2017. (Cited on pages 66, 73 , and 94).

[87] W. H. Slob and W. A. A. Monna. Bepaling van directe en diffuse straling en van zonneschijnduur uit 10-minuutwaarden van de globale straling. KNMI TR-136, 1991. (Cited on page 66).

[88] M. Kaltschmitt, W. Streicher, and A. Wiese. Renewable Energy: Technology, Economics and Environment. Springer-Verlag, 2007. doi: 10.1007/3-540-70949-5. (Cited on page 66).

[89] R. P. van Leeuwen, J. B. de Wit, J. Fink, and G. J. M. Smit. House thermal model parameter estimation method for model predictive control applications. In IEEE Powertech 2015, 2015. doi: 10.1109/ptc.2015.7232335. (Cited on page 66).

[90] R. Stamminger. Synergy potential of smart appliances. [Online] Available: http://www.smart-a.org, 2008. (Cited on page 66).

[91] K Kok. The PowerMatcher: Smart Coordination for the Smart Electricity Grid. $\mathrm{PhD}$ thesis, Vrije Universiteit Amsterdam, 2013. (Cited on pages 70, 73, and 75).

[92] J. Salom, A. J. Marszal, J. Widén, J. Candanedo, and K. B. Lindberg. Analysis of load match and grid interaction indicators in net zero energy buildings with simulated and monitored data. Applied Energy, 136:119-131, 2014. doi: 10.1016/j.apenergy.2014.09.018. (Cited on page 71).

[93] I. Sartori, A. Napolitano, and K. Voss. Net zero energy buildings: A consistent definition framework. Energy and Buildings, 48:220-232, 2012. doi: 10.1016/j.enbuild.2012.01.032. (Cited on page 71).

[94] E. Palacios-Garcia, A. Moreno-Muñoz, I. Santiago, I. Moreno-Garcia, and M. Milanés-Montero. PV hosting capacity analysis and enhancement using high resolution stochastic modeling. Energies, 10(1488):1-22, 2017. doi: 10.3390/en10101488. (Cited on page 71).

[95] J. Torriti. A review of time use models of residential electricity demand. Renewable and Sustainable Energy Reviews, 37:265-272, 2014. doi: 10.1016/j.rser.2014.05.034. (Cited on page 72).

[96] U. Wilke, F. Haldi, J-L. Scartezzini, and D. Robinson. A bottom-up stochastic model to predict building occupants time-dependent activities. Building and Environment, 60:254-264, 2013. doi: 10.1016/j.buildenv.2012.10.021. (Cited on page 72).

[97] M. A. López-Rodríguez, I. Santiago, D. Trillo-Montero, J. Torriti, and A. MorenoMunoz. Analysis and modeling of active occupancy of the residential sector in Spain: An indicator of residential electricity consumption. Energy Policy, 62: 742-751, 2013. doi: 10.1016/j.enpol.2013.07.095. (Cited on page 72). 
[98] J. Widén, M. Lundh, I. Vassileva, E. Dahlquist, K. Ellegård, and E. Wäckelgård. Constructing load profiles for household electricity and hot water from timeuse-data-modelling approach and validation. Energy and Buildings, 41(7):753-768, 2009. doi: 10.1016/j.enbuild.2009.02.013. (Cited on page 72).

[99] J.Widén and E. Wäckelgård. A high-resolution stochastic model of domestic activity patterns and electricity demand. Applied Energy, 87(6):1880-1892, 2010. doi: 10.1016/j.apenergy.2009.11.006. (Cited on page 72).

[100] S. Nebiolo. The potential for energy islands in the eastern Netherlands. Master's thesis, University of Twente, 2018. (Cited on pages 92 and 95).

[101] Agentschap NL. Voorbeeldwoningen 2011: Onderzoeksverantwoording, 2011. (Cited on page 92).

[102] A. Poullikkas. A comparative overview of large-scale battery systems for electricity storage. Renewable and Sustainable Energy Reviews, 27:778-788, 2013. doi: 10.1016/j.rser.2013.07.017. (Cited on page 108).

[103] G. J. May, A. Davidson, and B. Monahov. Lead batteries for utility energy storage: A review. Journal of Energy Storage, 15:145-157, 2018. doi: 10.1016/j.est.2017.11.008. (Cited on page 108).

[104] J. Cho, S. Jeong, and Y. Kim. Commercial and research battery technologies for electrical energy storage applications. Progress in Energy and Combustion Science, 48:84-101, 2015. doi: 10.1016/j.pecs.2015.01.002. (Cited on page 108).

[105] A.R. Dehghani-Sanij, E. Tharumalingam, M.B. Dusseault, and R. Fraser. Study of energy storage systems and environmental challenges of batteries. Renewable and Sustainable Energy Reviews, 104:192-208, 2019. doi: 10.1016/j.rser.2019.01.023. (Cited on page 108).

[106] A. Malhotra, B. Battke, M. Beuse, A. Stephan, and T. Schmidt. Use cases for stationary battery technologies: A review of the literature and existing projects. Renewable and Sustainable Energy Reviews, 56:705-721, 2016. doi: 10.1016/j.rser.2015.11.085. (Cited on page 108).

[107] D.A.J. Rand and P.T. Moseley. Chapter 13 - energy storage with lead-acid batteries. In P.T. Moseley and J. Garche, editors, Electrochemical Energy Storage for Renewable Sources and Grid Balancing, pages 201-222. Elsevier, 2015. doi: 10.1016/B9780-444-62616-5.00013-9. (Cited on page 108).

[108] Edited by:, P van Leeuwen, and B van de Leur. Chemiekaarten, chemical compound information database, 2019. Last accessed on 1-9-2019. (Cited on pages 108, 110, 111, and 112).

[109] P. Gottesfeld, F.H. Were, L. Adogame, S. Gharbi, D. San, M.M. Nota, and G. Kuepouo. Soil contamination from lead battery manufacturing and recycling in seven african countries. Environmental Research, 161:609-614, 2018. doi: 10.1016/j.envres.2017.11.055. (Cited on page 108). 
[110] L. Chen, Z. Xu, M. Liu, Y. Huang, R. Fan, Y. Su, G. Hu, Xu Peng, and Xn Peng. Lead exposure assessment from study near a lead-acid battery factory in china. Science of The Total Environment, 429:191-198, 2012. doi: 10.1016/j.scitotenv.2012.04.015. (Cited on page 108).

[111] G. Zubi, R. Dufo-López, M. Carvalho, and G. Pasaoglu. The lithium-ion battery: State of the art and future perspectives. Renewable and Sustainable Energy Reviews, 89:292-308, 2018. doi: 10.1016/j.rser.2018.03.002. (Cited on page 108).

[112] A. Mauger and C. M. Julien. Critical review on lithium-ion batteries: are they safe? sustainable? Ionics, 23(8):1933-1947, 2017. doi: 10.1007/s11581-017-2177-8. (Cited on page 108).

[113] T. M. Bandhauer, S. Garimella, and T. F. Fuller. A critical review of thermal issues in lithium-ion batteries. Journal of The Electrochemical Society, 158(3):R1-R25, 2011. doi: 10.1149/1.3515880. (Cited on page 108).

[114] Brandweer Nederland. [Online] Available: https://www.brandweer.nl, 2019. Last accessed on 21-12-2019. (Cited on page 108).

[115] F. R. Mclarnon and E. J. Cairns. The secondary alkaline zinc electrode. Journal of the Electrochemical Society, 138(2):645-646, 1991. doi: 10.1149/1.2085653. (Cited on pages 108 and 134).

[116] W Pelt. Zinc/Bromine battery electrolytes: electrochemical, physico-chemical and spectroscopic studies. $\mathrm{PhD}$ thesis, University of Ottawa, 1994. (Cited on page 108).

[117] H. Li, L. Ma, C. Han, Wang Z., Z. Liu, Z. Tang, and C. Zhi. Advanced rechargeable zinc-based batteries: Recent progress and future perspectives. Nano Energy, 62:550-587, 2019. doi: 10.1016/j.nanoen.2019.05.059. (Cited on page 108).

[118] Statista. [Online] Available: https://statista.com, 2020. Last accessed on 7-1-2020. (Cited on page 110).

[119] S.E. Kesler and A.C. Simon. Mineral Resources, Economics and the Environment. Cambridge University Press, 2015. ISBN 978-13-16368-58-9. (Cited on page 111).

[120] USGS. Mineral commodity summaries 2020: U.S. Geological Survey. 2020. ISBN 978-1-4113-4362-7. doi: 10.3133/mcs2020. (Cited on page 111).

[121] D. F. Quintero Pulido, M. V. ten Kortenaar, J. L. Hurink, and G. J. M. Smit. Characteristics of halide oxidation at graphite electrode for use in halde batteries. Sustainable Energy Technologies and Assessments, 33:14-23, 2019. doi: 10.1016/j.seta.2019.03.001. (Cited on page 112).

[122] D. F. Quintero Pulido. Energy Storage Technologies for Off-Grid Houses. PhD thesis, University of Twente, 2019. (Cited on page 112).

[123] M. de Alcantara Neto. Analysis of battery profiles for real-time application in smart grids. Master's thesis, University of Twente, 2019. (Cited on page 120).

[124] W Lu, C Xie, H Zhang, and X Li. Inhibition of zinc dendrite growth in zinc-based batteries. ChemSusChem, 11:3996-4006, 2018. doi: 10.1002/cssc.201801657. (Cited on page 134). 
[125] D. Grier, E. Ben-Jacob, R. Clarke, and L. M. Sander. Morphology and Microstructure in Electrochemical Deposition of Zinc. Physical Review Letters, 56(12):12641267, 1986. doi: 10.1103/physrevlett.56.1264. (Cited on page 134).

[126] H. B. Muralidhara and Y. Arthoba Naik. Electrochemical deposition of nanocrystalline zinc on steel substrate from acid zincate bath. Surface and Coatings Technol$o g y$, 202:3403-3412, 2008. doi: 10.1016/j.surfcoat.2007.12.012. (Cited on page 134).

[127] K. Fukami, S. Nakanishi, H. Yamasaki, T. Tada, Sonoda K., N. Kamikawa, N. Tsuji, H. Sakaguchi, and Y. Nakato. General mechanism for the synchronization of electrochemical oscilations and self-organized dendrite electrodeposition of metals with ordered $2 \mathrm{~d}$ and $3 \mathrm{~d}$ microstructures. Journal of Physical Chemistry C, 111:1150-1160, 2007. doi: 10.1021/jpo63462t. (Cited on page 134).

[128] K. Fukami, S. Nakanishi, T. Tada, H. Yamasaki, S. Sakai, S. Fukushima, and Y. Nakato. Self-organized periodic growth of stacked hexagonal wafers in synchronization with a potential oscillation in zinc electrodeposition. Journal of the Electrochemical Society, 152(7):C493-C497, 2004. doi: 10.1149/1.1932829. (Cited on page 134).

[129] I. Shitanda, R. Ichikawa, Y. Hosh, and M. Itagaki. A vegetable garden-like zinc dendritic patterning by electrodeposition. The Chemical Society of Japan, 43:113115, 2014. doi: 10.1246/cl.130921. (Cited on page 134).

[130] R. Koda, K. Fukami, T. Sakka, and Y. H. Ogata. A physical mechanism for suppression of zinc dendrites caused by high efficiency of the electrodeposition within confined nanopores. ECS Electrochemistry Letters, 2(2):D9-D11, 2013. doi: 10.1149/2.010302eel. (Cited on page 134).

[131] A. Gomes and M. I. da Silva Pereira. Pulsed electrodeposition of $\mathrm{Zn}$ in the presence of surfactants. Electrochimica Acta, 51:1342-1350, $2006 . \quad$ doi: 10.1016/j.electacta.2005.06.023. (Cited on page 134).

[132] A. Gomes and M. I. da Silva Pereira. Zn electrodeposition in the presence of surfactants Part I. Voltammetric and structural studies. Electrochimica Acta, 52: 863-871, 2006. doi: 10.1016/j.electacta.2006.06.025. (Cited on page 134).

[133] G.J.M Koper. An introduction to Interfacial Engineering. VSSD, 2007. ISBN 90-71301-95-8. (Cited on page 134).

[134] K. Raeissi, A. Saatchi, M. A. Golozar, and J. A. Szpunar. Texture and surface morphology in zinc electrodeposits. Journal of Applied Electrochemistry, 34:12491258, 2004. doi: 10.1007/s10800-004-1699-8. (Cited on page 135).

[135] T. Boiadjieva, M. Monev, A. Tomandl, H. Kronberger, and G. Fafilek. Electrochemical studies on $\mathrm{Zn}$ deposition and dissolution in sulphate electrolyte. Journal of Solid State Electrochemistry, 13:671-677, 2009. doi: 10.1007/s10008-008-0594-3. (Cited on page 135).

[136] S. Y. Zhang, Q. Li, B. Chen, S. Q. Xu, J. M. Fan, and F. Luo. Electrodeposition of zinc on $\mathrm{AZ} 91 \mathrm{D}$ magnesium alloy pre-treated by stannate conversion coatings. $\mathrm{Ma}$ terials and Corrosion, 61(10):860-865, 2010. doi: 10.1002/maco.200905435. (Cited on page 135 ). 
[137] E. E. Ferapontova, J. G. Terry, A. J. Walton, C. P. Mountford, J. Crain, A. H. Buck, P. Dickinson, C. J. Campbell, J. S. Beattie, P. Ghazal, and A. R. Mount. Electrochemical deposition of $\mathrm{Zn}$ on TiN microelectrode arrays for microanodes. Electrochemistry Communications, 9:303-309, 2007. doi: 10.1016/j.elecom.2006.09.005. (Cited on page 135).

[138] M. Granados-Neria, L. H. Mendoza Huizar, and C. H. Rios-Reyes. Electrochemical study about zinc electrodeposition onto gce and hopgg substrates. Quimica Nova, 34(3):439-443, 2011. doi: 10.1590/s0100-40422011000300014. (Cited on page 135).

[139] K. Raeissi, A. Saatchia, M. A. Golozara, and J. A. Szpunar. Effect of surface preparation on zinc electrodeposited texture. Surface and Coatings Technology, 197:229-237, 2005. doi: 10.1016/j.surfcoat.2004.09.024. (Cited on page 135).

[140] V. Vasilache, G. Gutt, and T. Vasilache. Studies about electrochemical plating with zinc - nickel alloys- the influence of deposition potential on stoichiometric composition. Revista de Chimie, 59(9):1005-1008, 2008. (Cited on page 135).

[141] A. Foyet, A. Hauser, and W. Schaefer. Template electrochemical deposition and characterization of zinc-nickel alloy nanomaterial. Journal of Elecroanalytical Chemistry, 604(2):137-143, 2007. doi: 10.1016/j.jelechem.2007.03.014. (Cited on page 135).

[142] A. Y. Musa, A. A. H. Kadhum, M. S. Takriff, and Q. J. M. Slaiman. Co-deposition of copper-zinc alloy in cyanide-based electrolytes. International Journal of Surface Science and Engineering, 2(6):541-549, 2008. doi: 10.1504/ijsurfse.2008.022290. (Cited on page 135).

[143] P. T. Olesen, T. Steenberg, E. Christensen, and N. J. Bjerrum. Electrolytic deposition of amorphous and crystalline zinc-calcium phosphates. Journal of Materials Science, 33(12):3059-3063, 1998. doi: 10.1023/a:1004379319348. (Cited on page 135).

[144] A. P. Abbott, J. C. Barron, G. Frisch, K. S. Ryder, and A. F. Silva. The effect of additives on zinc electrodeposition from deep eutectic solvents. Electrochimica Acta, 56:5272-5279, 2011. doi: 10.1016/j.electacta.2011.02.095. (Cited on page 135).

[145] M. Li, S. Luo, Y. Qian, W. Zhang, L. Jiang, and J. Shena. Effect of additives on electrodeposition of nanocrystalline zinc from acidic sulfate solutions. Journal of the Electrochemical Society, 154(11):D567-D571, 2007. doi: 10.1149/1.2772093. (Cited on page 135).

[146] J. L. Ortiz-Aparicio, Y Meas, G. Trejo, R. Ortega, T. W. Chapman, and E Chainet. Effects of organic additives on zinc electrodeposition from alkaline electrolytes. Journal of Applied Electrochemistry, 43:289-300, 2013. doi: 10.1007/s10800-0120518-x. (Cited on page 135).

[147] B. A. Boukamp. A nonlinear least squares fit procedure for analysis of immittance data of electrochemical systems. Solid State Ionics, 20:31-44, 1986. doi: 10.1016/0167-2738(86)90031-7. (Cited on pages 136 and 147). 
[148] B. A. Boukamp. Package for impedance/admittance data analysis. Solid State Ionics, 19:136-140, 1986. doi: 10.1016/0167-2738(86)90100-1. (Cited on pages 136 and 147).

[149] A. Lasia. Electrochemical Impedance Spectroscopy and its Applications. Springer, 2014. doi: 10.1007/978-1-4614-8933-7. (Cited on page 146).

[150] N. Alias and A. A. Mohamad. Morphology study of electrodeposited zinc from zinc sulfate solutions as anode for zinc-air and zinc-carbon batteries. Journal of King Saud University - Engineering Sciences, 27:43-48, 2015. doi: 10.1016/j.jksues.2013.03.003. (Cited on page 148). 


\section{List of Publications}

[H:1] K. X. Perez, M. Baldea, T. F. Edgar, G. Hoogsteen, R. P. van Leeuwen, T. van der Klauw, B. Homan, J. Fink, and G. J. M. Smit. Soft-islanding a group of houses through scheduling of $\mathrm{chp}, \mathrm{pv}$ and storage. In 2016 IEEE International Energy Conference (ENERGYCON), pages 1-6, 2016. doi: 10.1109/energycon.2016.7513972.

[H:2] B. Homan, R. P. van Leeuwen, L. Zhu, J. B. de Wit, and G. J. M. Smit. Validation of a predictive model for smart control of thermal and electrical energy storage. In 2016 IEEE International Energy Conference (ENERGYCON), pages 1-6, 2016. doi: 10.1109 /energycon.2016.7513872.

[H:3] B. Homan, R. P. van Leeuwen, M. V. ten Kortenaar, and G. J. M. Smit. A comprehensive model for battery state of charge prediction. In 2017 IEEE Manchester PowerTech, pages 1-6, 2017. doi: 10.1109/ptc.2017.7980943.

[H:4] B. Homan, R. P. van Leeuwen, M. V. ten Kortenaar, and G. J. M. Smit. A simple yet accurate model for battery state of charge prediction. Proceedings of the Energy-Open Workshop(WP 17-01), pages 24-25, 2017. ISSN $0929-0672$.

[H:5] B. Homan, V. M. M. J. Reijnders, G. Hoogsteen, J. L. Hurink, and G. J. M. Smit. Implementation and verification of a realistic battery model in the demkit simulation software. In 2018 IEEE PES Innovative Smart Grid Technologies Conference Europe (ISGT-Europe), pages 1-6, 2018. doi: 10.1109/isgteurope.2018.8571691.

[H:6] B. Homan, M. V. ten Kortenaar, J. L. Hurink, and G. J. M. Smit. A realistic model for battery state of charge prediction in energy management simulation tools. Energy, 171:205-217, 2019. ISSN 0360-5442. doi: 10.1016/j.energy.2018.12.134.

[H:7] B. Homan, S. Nebiolo, G. Hoogsteen, J. L. Hurink, and G. J. M. Smit. Improving the degree of autarky of a 16 house neighbourhood in the Netherlands - A case study. In 2019 IEEE PES Innovative Smart Grid Technologies Europe (ISGT-Europe), pages 1-5, 2019. doi: 10.1109/ISGTEurope.2019.8905491.

[H:8] B. Homan, G. Hoogsteen, S. Nebiolo, J. L. Hurink, and G. J. M. Smit. Maximizing the degree of autarky of a 16 house neighbourhood by locally produced energy and smart control. Sustainable Energy, Grids and Networks, 20:100270, 2019. ISSN 2352-4677. doi: 10.1016/j.segan.2019.100270.

[H:9] B. Homan, D. F. Quintero-Pulido, M.V. ten Kortenaar, J. L. Hurink, and G. J. M. Smit. Influence of co-depositor materials and modification of substrate on the formation of dendrites on the anode of a zinc-based secondary battery. Sustainable Energy Technologies and Assessments, 42:100820, 2020. ISSN 2213-1388. doi: 10.1016/j.seta.2020.100820. 
[H:10] C. B. Minkenberg, B. Homan, J. Boekhoven, B. Norder, G. J. M. Koper, R. Eelkema, and J. H. van Esch. Responsive wormlike micelles from dynamic covalent surfactants. Langmuir, 28(38):13570-13576, 2012. doi: 10.1021/la302294r.

198

\section{THIS THESIS}

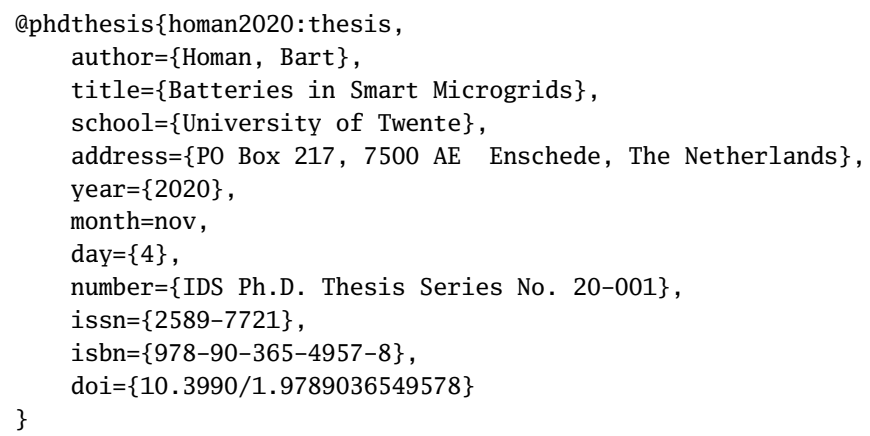

Biв $\mathrm{T}_{\mathrm{E}} \mathrm{X}$ of this thesis 


\section{About the author}

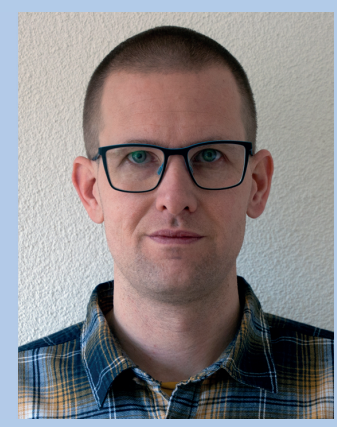

Bart Homan received his BSc degree in Chemical Engineering \& Biochemical Engineering (2010) and his MSc degree in Molecular Engineering (2012) from the Delft University of Technology, Delft, The Netherlands. After receiving his MSc degree he went on to work at $\mathrm{Dr}$ Ten B.V. in research and development of various products, most notably the Seasalt battery. In 2014 he expanded his research beyond the chemical aspect of batteries, and started working towards a PhD degree in the Computer Architecture for Embedded Systems (CAES) group at the University of Twente.

His PhD research focussed on the integration of batteries in (smart)microgrids, but also includes the chemical and practical aspects of battery design. His research was done in the Energy Group, a multidisciplinary team consisting of members of the CAES and Discrete Mathematics and Mathematical Programming (DMMP) groups and in close collaboration with Dr Ten B.V.

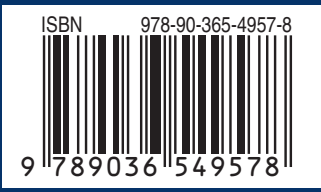




\title{
STELLINGEN
}

behorende bij het proefschrift

\section{Batteries in Smart Microgrids}

\author{
door Bart Homan,
}

te verdedigen op woensdag 4 november 2020

1 - Een model hoeft de werkelijkheid niet met perfecte nauwkeurigheid te voorspellen zolang de nauwkeurigheid maar voldoende is voor de toepassing waarvoor het model gebruikt wordt.

(Dit proefschrift)

2 - Een soft-islanded microgrid geeft bijna alle voordelen van een islanded microgrid, voor slechts een fractie van de kosten.

(Dit proefschrift)

3 - Als je de milieubewustheid, duurzaamheid, en betaalbaarheid van de Zeezoutbatterij in ogenschouw neemt, is de Zeezoutbatterij een veelbelovend alternatief voor stationaire doeleinden.

(Dit proefschrift)

4 - Samenwerking tussen wetenschappers met verschillende achtergronden leidt tot creatieve en unieke oplossingen, terwijl de ervaring de betrokken wetenschappers een breder bewustzijn geeft en hen meer openstelt voor andere perspectieven.

5 - Als, aan de start van een onderzoek de onderzoeksvragen en relevante variabelen niet duidelijk zijn gedefinieerd, maar de gewenste doelen wel, is het onwaarschijnlijk dat deze doelen aan het einde van het onderzoek gehaald worden.

6 - Een technologie die bedoeld is om het aandeel hernieuwbare energie in ons totale energieverbruik te vergroten, moet op de eerste plaats betaalbaar zijn voor de eindgebruiker.

7 - De Scoutingwet schrïft voor: "Een Scout zorgt goed voor de natuur." Deze wet zou in breedst mogelijke zin geïnterpreteerd en universeel toegepast moeten worden. 


\title{
Propositions
}

accompanying the thesis

\section{Batteries in Smart Microgrids}

\author{
by Bart Homan,
}

to be defended on Wednesday, the $4^{\text {th }}$ of November, 2020

1 - A model does not have to predict reality with perfect accuracy as long as the accuracy is sufficient for the application it is used for.

(This thesis)

2 - A soft-islanded microgrid provides almost all of the benefits of an islanded microgrid, while requiring only a fraction of the costs.

(This thesis)

3 - Considering its environmental responsibility, durability and affordability, the Seasalt battery is very promising for stationary applications. (This thesis)

4 - Cooperation between scientists of different backgrounds leads to creative, innovative and unique solutions, while the experience leaves the involved scientists more broadly informed and more open to other points of view.

5 - If, at the start of a research, the research question and the relevant variables are not clearly defined but the desired goals are, it is unlikely that these goals are satisfactorily achieved at the end of the research.

6 - A technology intended to increase the share of renewable energy in our total energy usage should foremostly be affordable for the end user.

7 - Scouts law dictates: "A Scout cares for nature." This law should be interpreted in the broadest possible sense and should be universally applied. 